\title{
Changing use of Lizard Island over the past 4000 years and implications for understanding Indigenous offshore island use on the Great Barrier Reef
}

\author{
Ariana B.J. Lambrides ${ }^{\mathrm{a}}$, Ian J. McNiven ${ }^{\mathrm{b}}$, Samantha J. Aird ${ }^{\mathrm{c}}$, Kelsey A. Lowe ${ }^{\mathrm{d}}$, Patrick \\ Moss $^{\text {e,f }}$, Cassandra Rowe ${ }^{\mathrm{g}}$, Clair Harris ${ }^{\mathrm{d}}$, Cailey Maclaurin ${ }^{\mathrm{a}}$, Sarah A. Slater ${ }^{\mathrm{a}}$, Kylie Carroll ${ }^{\mathrm{a}}$, \\ Malia H. Cedar ${ }^{\mathrm{h}}$, Fiona Petchey ${ }^{\mathrm{i}, \mathrm{a}}$, Christian Reepmeyer ${ }^{\mathrm{a}}$, Matthew Harris ${ }^{\mathrm{j}}$, Johnny Charliek, ${ }^{\mathrm{k}}$, \\ Elaine McGreen ${ }^{\mathrm{k}}$, Phillip Baru ${ }^{\mathrm{k}}$ and Sean Ulm,
}

\begin{abstract}
${ }^{a}$ ARC Centre of Excellence for Australian Biodiversity and Heritage, College of Arts, Society and Education, James Cook University, PO Box 6811, Cairns, QLD 4870, Australia; ${ }^{\mathrm{b}}$ ARC Centre of Excellence for Australian Biodiversity and Heritage, Monash Indigenous Studies Centre, Monash University, Clayton, VIC 3800, Australia; ${ }^{\mathrm{c}}$ ARC Centre of Excellence for Coral Reef Studies, James Cook University, Townsville, QLD 4811, Australia; ${ }^{\text {d }}$ School of Social

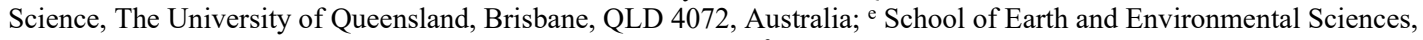
The University of Queensland, Brisbane, QLD 4072, Australia; ${ }^{\mathrm{f}}$ ARC Centre of Excellence for Australian Biodiversity and Heritage, Australian National University, Canberra, ACT 0200, Australia; ${ }^{\mathrm{g}}$ ARC Centre of Excellence for Australian Biodiversity and Heritage, College of Science and Engineering, James Cook University, PO Box 6811, Cairns, QLD 4870, Australia; ${ }^{\mathrm{h}}$ Anthropology Department, University of Colorado, Boulder, CO 80309, United States; ${ }^{\mathrm{i}}$ Radiocarbon Dating Laboratory, Division of Health, Engineering, Computing and Science, University of Waikato, Hamilton 3216, New Zealand; ${ }^{j}$ Niche Environment and Heritage, Cairns, QLD 4870, Australia; ${ }^{\mathrm{k}}$ Dingaal Traditional Owner, C/- Hope Vale Post Office, QLD 4895, Australia
\end{abstract}

$\dagger$ Deceased

* Corresponding author sean.ulm@jcu.edu.au

\begin{abstract}
Archaeological records documenting the timing and use of northern Great Barrier Reef offshore islands by Aboriginal and Torres Strait Islander peoples throughout the Holocene are limited when compared to the central and southern extents of the region. Excavations on Lizard Island, located $33 \mathrm{~km}$ from Cape Flattery on the mainland, provide high resolution evidence for periodic, yet sustained offshore island use over the past 4000 years, with focused exploitation of diverse marine resources and manufacture of quartz artefacts. An increase in island use occurs from around 2250 years ago, at a time when a hiatus or reduction in offshore island occupation has been documented for other Great Barrier Reef islands, but concurrent with demographic expansion across Torres Strait to the north. Archaeological evidence from Lizard Island provides a previously undocumented occupation pattern associated with Great Barrier Reef Late Holocene island use. We suggest this trajectory of Lizard Island occupation was underwritten by its place within the Coral Sea Cultural Interaction Sphere, which may highlight its significance both locally and regionally across this vast seascape.
\end{abstract}

\section{Introduction}

There are limited archaeological records documenting the timing and use of Great Barrier Reef offshore islands throughout the Holocene, particularly when compared to available evidence from elsewhere along the Queensland coast (e.g. Barker 2004; Beaton 1978, 1985; Border 1999; Brady et al. 2013; Lentfer et al. 2013; McNiven et al. 2014; Mills 1992; Rowland 1980, 1984; Wright 2018). However, in the context of the broader social and cultural seascape, the Torres Strait Islands have been the most extensively investigated region, and provide an unparalleled record of island occupation in the region in terms of the development of specialised maritime societies (e.g. Ash et al. 2010; Barham 2000; Brady 2010; Brady and Ash 2018; Carter 2004; Crouch 2015; Crouch et al. 2007; David et al. 2005, 2009; David and Weisler 2006; Ghaleb 1990; McNiven 2006, 2015; McNiven et al. 2009, 2015; McNiven and Feldman 2003; Wright et al. 2013). The use of offshore islands by Aboriginal and Torres Strait Islander peoples throughout the Holocene in northeast Australia has been widely debated (e.g. Barker 2004; Beaton 1978; Border 1999; McNiven et al. 2014; Rowland 1996; Sim and Wallis 2008; Ulm 2013), particularly the timing of island use, the evidence for permanent or semi-permanent island- based marine economies, the associated extent of mainland connections and movement of people, and the wider social and cultural implications of the observed changes in island occupation during the Mid-to-Late Holocene.

Currently, the earliest evidence for offshore island use has been reported from the central and southern extents of the Great Barrier Reef region. Barker (2004) argued that records from the Whitsunday Islands indicate people were marine adapted prior to the time when Nara Inlet 1 (Hook Island) was cut off from the mainland (Figure 1), and adjusted to $\sim 1500$ years of changing coastlines and island development between $\sim 9000$ and $7400 \mathrm{cal} \mathrm{BP}$, and continued to access and exploit marine resources until the recent past (see also Rowland 1996). In contrast, the Otterbourne Island 4 site (Shoalwater Bay Islands) was occupied at $5200 \mathrm{cal}$ BP some 3000 years after island development. This time-lag between island formation and colonisation was attributed to the development of fringing reefs and associated expansion in turtle populations, a key socially important resource (McNiven et al. 2014). Use of these islands generally predates the earliest evidence for migration of ceramic-bearing New Guinea peoples into Torres Strait and Lapita expansion into Remote Oceania, and thus occupation of Great Barrier Reef offshore islands was not facilitated by the introduction of canoeing 
B

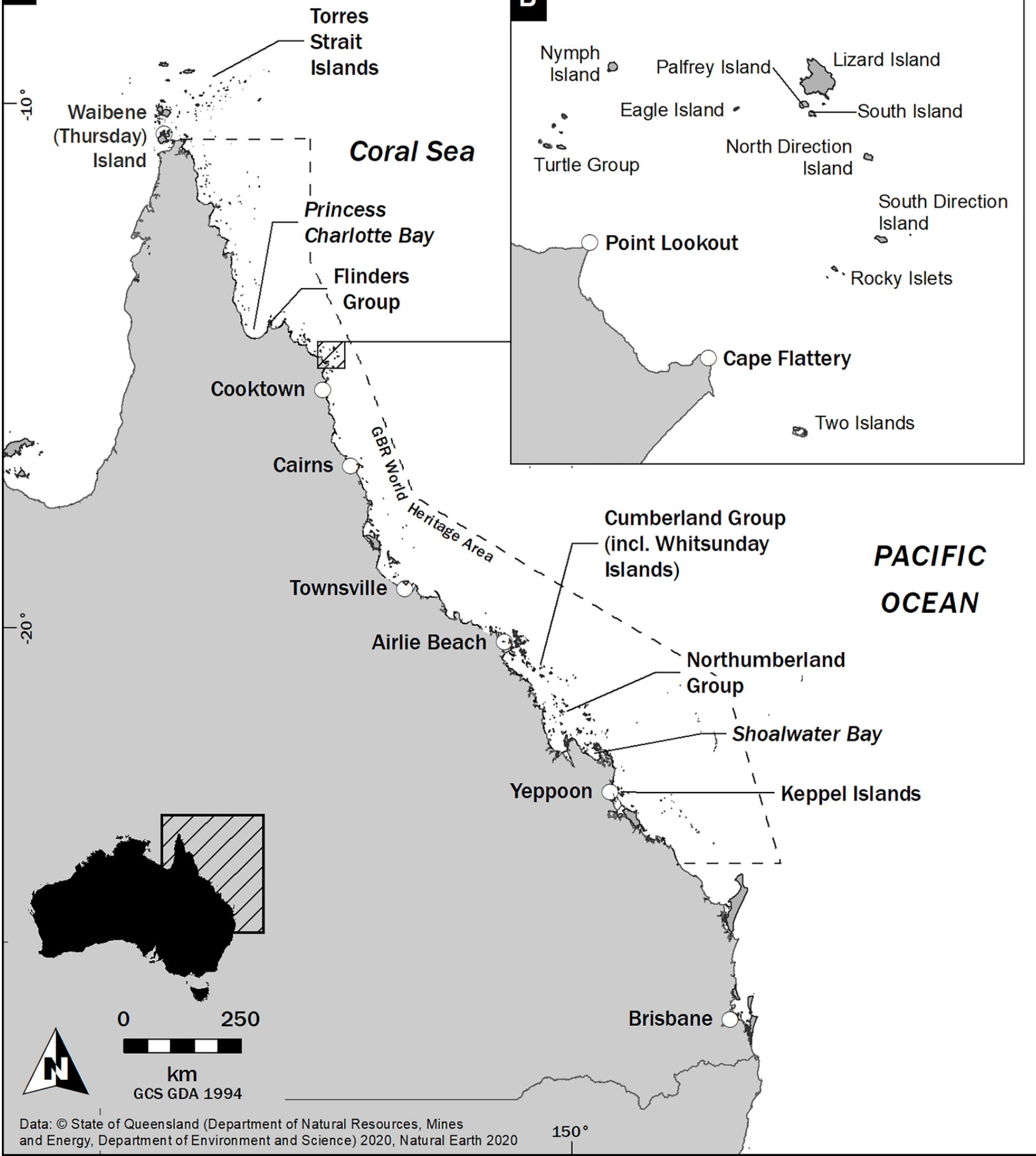

Figure 1. Australia, showing the location of Queensland, and (A) key places on the Great Barrier Reef mentioned in text, and (B) the islands between the mainland and Lizard Island Group. The dotted line shows the extent of the Great Barrier Reef World Heritage Area. 
technologies from New Guinea (Denham et al. 2012; McNiven et al. 2006, 2011; Rowland 1996). Aboriginal people of the central and southern Queensland coast developed bark canoes and successfully voyaged offshore to access these islands throughout the Holocene (McNiven et al. 2014; Rowland 1984).

As characterised by McNiven et al. (2014) for the central and southern Great Barrier Reef region, the available archaeological evidence supports the occurrence of an island colonisation phase between $\sim 5000$ and 3000 years ago. A notable change in the use of these islands occurs from c.30003500 years ago, which has been inferred from increases in archaeological discard rates, changes in targeted resources, and the use of new technologies. This wider change in island occupation has been attributed to the expansion of coastal resources following sea-level stabilisation (Border 1999; Rowland 1999), or the restructuring of populations and interregional social systems, including controlled resource access (Barker 2004), yet all changes are argued to be underwritten by the emergence of permanent island-based economies (i.e. Cumberland Group, Northumberland Group, and North Keppel Island). Recent work on the Shoalwater Bay Islands (Northumberland Group) indicates there is no compelling evidence for permanent island-based economies (McNiven et al. 2014), unlike that documented for the Whitsunday and Keppel Islands (Barker 2004; Rowland 1999). The increased use of Shoalwater Bay Islands from 3000-3500 years ago was likely driven by demographic pressures on the mainland (e.g. increased demand on resources or a need to expand and/or acquire new territories), but these communities still had territory that extended to the mainland, and would likely visit these offshore islands periodically throughout the year (McNiven et al. 2014).

An absence or decrease in the use of islands from $\sim 2000$ to 1000 years ago was observed for sites in the Cumberland Group, Keppel Islands, and Northumberland Group (Barker 1996; Border 1999; Lamb and Barker 2001; McNiven et al. 2014; Rowland 1981, 1982, 1984, 1985, 1996). These occupation gaps have been linked to a corresponding period of high amplitude and low frequency ENSO events $(\sim 2500$ 1000 years ago), peaking at $\sim 1300$ years ago (Conroy et al. 2008; Gagan et al. 2004; Ulm 2011). Furthermore, Dechnik et al. (2017) documented a $\sim 2300$ year hiatus in lateral reef accretion between $\sim 3900-3600$ cal BP and $\sim 1500-1300$ cal BP along the Great Barrier Reef inner and mid-outer shelf reefs due to falling sea-levels, but excluding the reefs roughly between Cairns and Townsville, where no hiatus was observed likely due to increased subsidence for this region. Reef flat growth re-initiated $\sim 2000$ years ago, but was restricted to the slope and back reef lagoon (Perry and Smithers 2011). Most recently, evidence from the inshore southern Great Barrier Reef indicates that while hiatus or reef 'turn-off' events occurred during the past 5000 years, these were not regionally uniform events, unlike the evidence available for the northern extent of the region (Leonard et al. 2020). There is still a degree of uncertainty as to how these recent changes in the use of islands - from $\sim 2000$ to 1000 years ago - may relate to broader environmental change. Both intensified ENSO activity (e.g. Gagan et al. 2004) and - to a varying extent $-\mathrm{a}$ hiatus in reef flat accretion rates (e.g. Leonard et al. 2020) could have influenced reef flat communities and the predictability of accessing these resources. Furthermore, variations in coastal vegetation and movement of associated shorelines have been identified through the reconstruction of mangrove vegetation histories (Genever et al. 2003; Grindrod 1985). Ideally, sub-seasonal records at local scales of foraging and environmental change from these offshore island archaeological sites are required to disentangle these complex drivers of change. Nonetheless, following this $\sim 1000$-year hiatus or decrease in offshore island use, there is a notable increase in island use over the past 1000 years in the central and southern extents of the Great Barrier Reef region, as characterised by the relatively high discard rates and in some instances a change in the range of resources and technologies utilised (Barker 2004; Border 1999; McNiven et al. 2014; Rowland 1982, 1996).

There are limited records documenting variability in offshore island use for the northern Great Barrier Reef, with Flinders and Lizard Island Groups providing the most detailed evidence (Figure 1). It should be noted that work on Hinchinbrook Island by Campbell $(1979,1982$ a) does provide evidence of occupation from at least 2000 years ago at the Leefe Peak site, but the samples that provided these early dates were recovered from an exposed section of a midden, which had been cut by a seasonal creek, and are not associated with controlled stratigraphic excavations. Scraggy Point is the only excavated site on Hinchinbrook Island, and while dating inversions were reported, it appears the site was occupied in the past 400-500 years, with evidence for exploitation of molluscs, fish, and turtle (Campbell 1982b). Beaton (1985) initially investigated offshore island use on Stanley Island at Yindayin rockshelter, reporting the earliest evidence of site occupation at $\sim 2500$ cal BP, with cultural materials, including molluscs, fish, turtle, wallaby remains, and flaked shell (Geloina coaxans) (see Harris et al. 2017). The site was reexcavated in 2016 and generated a new basal date of $6286 \mathrm{cal}$ BP (Wright 2018). Presently only detailed molluscan analyses are available, but evidence suggests an initial phase of low intensity site occupation, followed by a 3000 year hiatus in site use until $2938 \mathrm{cal} \mathrm{BP}$, and occupation through to $2083 \mathrm{cal}$ BP when the site was abandoned until the recent past $(\sim 0-172$ cal BP). This period of site abandonment corresponds with occupation of the Princess Charlotte Bay chenier plain on the adjacent mainland, and the peak in Tegillarca granosa mound building at $\sim 1000$ cal BP (Beaton 1985). The most recent phase of site occupation at Yindayin rockshelter is associated with the highest concentration of cultural material discard, with a notable shift from hard substrate dwelling molluscan species (e.g. Nerita spp.) to mangrove species (Terebralia spp.) (Wright 2018). Similarly, Lizard Island has been a focus of archaeological interest since the initiation of island-focused research agendas in the wider Great Barrier Reef region during the mid-to-late 1970s (Beaton 1973; Specht 1978). Excavation efforts have primarily targeted Site 17 Freshwater Bay Midden (FBM, Lizard Island), and provided the earliest evidence for island use at 3656 cal BP, but with a notable increase in site use over the past 2000 years, particularly an expansion in the exploitation of marine resources (Lentfer et al. 2013; Mills 1992).

Significantly, the available archaeological evidence for the use of Lizard Island does not record an occupation hiatus between 2000 and 1000 cal BP, a regional trend that is well documented for the central and southern Great Barrier Reef, and most recently for the northern extent at Stanley Island (Barker 2004; Border 1999; Lentfer et al. 2013; McNiven et al. 2014; Mills 1992; Rowland 1996; Wright 2018). It is 
apparent that more records of Holocene Great Barrier Reef offshore island use are needed to facilitate both local and more nuanced regional models of change. Outcomes of previous Lizard Island archaeological investigations also suggested that further excavations were required to explore variability in the occupation history of the Lizard Island Group, particularly forager decision-making and landscape use through time. Here we present the outcomes of the Site 3 Mangrove Beach Headland Midden (MBHM), Lizard Island excavations, detailing the broader palaeoenvironmental context and variability in the Late Holocene occupation of the site. Results have implications for understanding the timing and use of offshore islands, increasing the limited records available from northeast Australia, and enhancing our ability to consider the dynamics of island occupation along the Great Barrier Reef during the Holocene.

\section{Lizard Island Group}

\section{Environmental Context}

There is variability in the width of the continental shelf along the length of the Great Barrier Reef, and as such, the impacts of Mid-to-Late Holocene sea-level changes were not consistent in this region. The timing and magnitude of these changes in sea-level between the inner/coastal reefs and the outer reefs are still widely debated, and further emphasise the need for locally specific sea-level curves to assess the influence of these changes on offshore island occupation and use (Chappell et al. 1983; Lewis et al. 2013; Nakada and Lambeck 1989). With Early Holocene rising sea-levels, Lizard is estimated to have become an island around 10,000 cal BP (Lewis et al. 2013; Williams et al. 2018), which is further supported by the Early-to-Mid-Holocene establishment of mangrove forests and contraction of nearcoastal palm and grass-dominated vegetation documented during this period (Proske and Haberle 2012). The available sea-level indicator data derived from oyster and microatoll evidence from Lizard Island and the broader region suggests a 0.5 to $1.0 \mathrm{~m}$ high-stand between 6500 and 2300 cal BP (Chappell et al. 1983; Wright 2011; Zwartz 1995). The highstand was potentially $0.5 \mathrm{~m}$ lower than has been recorded at coastal sites due to hydro-isostatic influences (Lambeck and Nakada 1990; Lewis et al. 2013). Rapid sea-level fall to modern levels along the northeast Australian coastline between 1200 and 800 cal BP were documented using modern and fossil oysters, but it is currently unknown as to whether this fall was stepped or smooth (Lewis et al. 2015).

Today the northern Great Barrier Reef is characterised by a continuous line of ribbon reefs that are situated on the shelf edge and enclose a narrow $(\sim 50 \mathrm{~km})$ and shallow $(<40 \mathrm{~m}$ in depth) continental shelf (Orme and Flood 1977; Rees et al. 2006). The region is unique in the wider Great Barrier Reef region due to the prominent north-south trending line of granite/continental islands (Lizard Island Group, North Direction Island, and South Direction Island). The islands are mapped as Finlayson Granite of Permian age (Lucas 1965), but more recent work has suggested that some of the granite may be of Triassic age (Tochilin et al. 2012).

The Lizard Island Group is situated $33 \mathrm{~km}$ off the coast of Cape Flattery, $93 \mathrm{~km}$ northeast of Cooktown, and only $16 \mathrm{~km}$ from the outer barrier reef and the edge of the continental shelf. The group comprises Lizard Island (highest elevation $395 \mathrm{~m}$ above present sea-level, $\sim 10 \mathrm{~km}^{2}$ in area), the largest island, and the adjacent Palfrey Island, South Island, Osprey Islet, and Bird Islets, all linked by an expansive fringing reef that encloses a deep lagoon $(\sim 10 \mathrm{~m})$, which developed during the Holocene. At the northeast extent of the lagoon there is a 90 m-wide channel, which facilitates tidal flushing, with daily ranges from $\sim 3$ to $0.3 \mathrm{~m}$ (Kinsey 1979; Rees et al. 2006). Eagle Island is several kilometres to the west of Lizard Island and is an important seabird breeding habitat (Smith and Buckley 1986; Smith 1987). Southeast trade winds ( 15-30 knots) predominantly blow through much of the year between March and September, and strongly influence the direction of water currents and benthic community structure.

The reef platform around Lizard Island is $16.7 \mathrm{~km}^{2}$ in area, with many reefs in the lagoon rising steeply from $\sim 20-30 \mathrm{~m}$ in depth to form a distinct reef crest, expansive reef flat, back reef, and subside back to an intra-reefal lagoon (Madin et al. 2006). The outer reef slope and crest are dominated by live coral, and this forms a continuous coral band along the outer margin of the barrier and fringing reef system (Hamylton et al. 2014; Saunders et al. 2015). Reef development is the most extensive on the windward margin in the southeast - from South Island across to Bird Islets and adjacent to Coconut Beach - in contrast, patch reefs dominate the western margin of the reef platform (e.g. Watson's Bay, Mermaid Cove). The reef flat adjacent to Mangrove and Trawler Beaches - in proximity to Site $3 \mathrm{MBHM}$ - is characterised by low density seagrass (e.g. Halodule uninervis and Thalassia hemprichii), coral, and sparse rubble and algae on sand, and the lagoonal areas are predominantly sand, but with sparse coral patches, rubble, and algae (Hamylton et al. 2014; Saunders et al. 2015). These marine habitats support diverse faunal communities, including small reef fish such as damselfish (pomacentrids), wrasse (labrids), parrotfish (scarids), and sharks (e.g. black tip reef shark, Carcharhinus melanopterus) (Frisch et al. 2016; Goatley and Bellwood 2012; Leis 1986). Seagrasses provide important grazing habitats for green sea turtles (Chelonia mydas) and dugong (Dugong dugon). Infrequent nesting of turtles on Lizard Island has been observed (Goatley et al. 2012), and dugong feeding trails have been documented adjacent to Mangrove Beach (McKenzie et al. 1997). Dominant molluscan species include clams (e.g. Hippopus hippopus and Tridacna spp.), oyster (Ostreidae), cone snails (Conidae), conchs (Strombidae), and nerites (Neritidae) (Alder and Braley 1989; Robertson 1981).

Thirteen distinct vegetation communities have been characterised on Lizard Island. The landscape is dominated by Themeda grassland, and a complex of low vine forest and eucalypt woodland, dominated by Eucalyptus tessellaris (Byrnes et al. 1977; Lentfer et al. 2013). The region adjacent to Site 3 MBHM consists of a mosaic of plant communities. A small patch of mangrove trees (Rhizophora stylosa) has established around the rock headland between Mangrove and Trawler Beaches, grasslands cover the valleys and granitic hills (T. australis and Arundinella nepalensis) merging with shrub-dominated heathland (Thryptomene oligandra and Acacia humifusa). The southwest extent of Mangrove Beach is comprised of a woodland dominated by Eucalyptus tessellaris and Acacia crassicarpa (Byrnes et al. 1977).

No medium-to-large bodied mammals have been recorded on the island, but small mammals are the black flying fox (Pteropus alecto), dusky leaf-nosed bat (Hipposideros ater), and two rat species (Hydromys chrysogaster and Melomys capensis). It is believed that $H$. chrysogaster is a more recent 
introduction in the last decade, and M. capensis is a previously unrecorded native rat species (Bryant 2013; Reef et al. 2014). Reptiles (snakes and lizards), including the large yellowspotted monitor (Varanus panoptes), are found on Lizard Island (Llewelyn et al. 2014). Birds (land and shore birds) include a variety of resident and visiting species that occupy diverse habitats (Smith 1987).

Permanent freshwater is available on Lizard Island, historically documented by Captain James Cook on the northern extent of Watson's Bay where water was collected from a creek (Beaglehole 1962). This, now brackish, water source flows into the sea at the southern end of the beach. Today freshwater is pumped from two bores situated in the pandanus swamp inland from Watson's Bay. Freshwater is also accessible from springs on the island interior and rim, including Mangrove Beach (Lentfer et al. 2013; Mills 1992).

\section{Ethnographic and Archaeological Context}

Lizard Island is known as Jigurru or Walmbaar by the Dingaal traditional owners (Lentfer et al. 2013; Phillip Baru, Dingaal elder, pers. comm., 2020). Dingaal elder, Gordon Charlie, characterised Lizard Island as a highly significant place. The island was the site of initiations, intergroup gatherings, judicial deliberations, and a place for knowledge to be passed down from the 'clever men' to young males (Lentfer et al. 2013; Mills 1995a). When young males were initiated, these visits were usually for several months, indicating that in the recent past Lizard Island may not have been permanently occupied. Phillip Baru (pers. comm., 2020) described the Dingaal people travelling to Lizard not only for initiation, but also to access foods such as wild yam, shellfish, fish, and turtle. In 1770 and 1848, structures ('huts') were observed by early European explorers on Lizard Island, along with hearths, and scatters of shellfish, fish and turtle remains (Beaglehole 1962; Macgillivray 1852). Cook also observed canoes, and based on the description these were likely dugout canoes (Beaglehole 1962; Lentfer et al. 2013; Mills 1992). Macgillivray (1852) documented the expansiveness of the reef adjacent to Eagle Island, particularly noting the extensive shellfish populations, and describing evidence of what was believed to be 'turtle feasts'.

Ethnohistoric, ethnographic, and archaeological evidence supports the movement and interaction of Aboriginal people and Torres Strait Islanders along the northeast coast of Queensland as far south as Lizard Island. These interactions are thought to be part of an expansive seascape that linked communities from the Gulf of Papua and northern Queensland, termed by McNiven et al. (2004:284) the Coral Sea Cultural Interaction Sphere (see also Barham 2000; Haddon 1935; Laade 1969; McCarthy 1939; McNiven 2015, 2019; McNiven et al. 2004; Moore 2000; Rowland 1987). There have been reports of Torres Strait Islanders from Warraber and Poruma Islands (Central Islands) sailing some $600 \mathrm{~km}$ southeast to Lizard Island to source 'clubstone' for trade with Mer (Eastern Islands) (Laade 1969). Furthermore, pottery finds on the southern coast of Papua New Guinea dating 2600-2900 years ago (David et al. 2011; McNiven et al. 2011), and in Torres Strait dating 2500 years ago (McNiven et al. 2006), have led to the consideration of possible Melanesian cultural influences along the east coast of Australia (McNiven et al. 2011). The recovery of pottery sherds of possible Melanesian origin during multiple seasons of excavation (2009, 2010, and 2012) at the Mangrove Beach
Intertidal Site on Lizard Island (Lentfer et al. 2013; Tochilin et al. 2012) potentially provides supporting evidence for these influences.

Archaeological research was first conducted on Lizard Island as part of broader survey efforts targeting islands and cays of the northern Great Barrier Reef. Beaton (1973) surveyed the central saddle region of Lizard Island and the south-facing dunes, all in the relative vicinity of the modern airstrip, most notably documenting a large midden deposit that contained numerous molluscan taxa and quartz artefacts. Specht (1978) conducted a more extensive survey of Lizard Island several years later to determine the viability of a dedicated archaeological study of the region, and recorded several additional middens and stone arrangements, including Site $3 \mathrm{MBHM}$ and Site 17 FBM. Situated on the southern extent of the island, adjacent to Freshwater Beach, and on the access road to the Lizard Island Research Station, Site 17 FBM was excavated initially by Mills (1992) and most recently by Lentfer et al. (2013). Excavations of Site 17 FBM indicate Lizard Island was first occupied by 3656 cal BP, with an increase in the intensity of site use at $\sim 1725$ cal BP and through to the recent past, as evidenced by increased discard rates of quartz artefacts and marine faunal remains (molluscs, fish, turtle, and dugong) (Lentfer et al. 2013; Mills 1992). Additionally, Mills (1992, 1995a, 1995b) conducted comprehensive surveys of Lizard Island, recording 21 middens, four stone arrangements, and two art sites. One of these arts sites - Site 18 Gecko Shelter - situated at the southern extent of Cook's Look at the base of the ridge on a densely vegetated boulder slope was excavated, and returned limited cultural material, but Mills (1992) hypothesised this site may have been more recently utilised as a lookout to Watson's Bay to observe European activity in the region.

Since 2012, successive field seasons directed by Ulm and McNiven have been conducted in collaboration with Traditional Owners, and include extensive survey of Lizard, Palfrey, South, and North Direction Islands, recording of stone arrangements (Fitzpatrick et al. 2018) and art sites (Arnold 2020), and excavations on South Island and in the lagoon itself. This research program will be comprehensively reported elsewhere.

\section{Site 3 Mangrove Beach Headland Midden}

Site $3 \mathrm{MBHM}$ is a large, stratified shell midden situated on the headland between Mangrove Beach (a sheltered lagoonal embayment) and Trawler Beach on the southern coast of Lizard Island (Figures 2-4). The site was approximately 2250 $\mathrm{m}^{2}$ in area in 2013, which was significantly larger than originally recorded by Specht (1978) who documented an area of 75-100 $\mathrm{m}^{2}$ and later by Mills (1992) who estimated the site to be $\sim 300 \mathrm{~m}^{2}$ in area. The expansion in recorded site size over the past several decades may be indicative of recent cyclonic activity and erosional processes increasingly exposing the subsurface deposit. The surface of the site is currently characterised by the shells of molluscs such as Conomurex luhuanus, Tridacna spp., Lambis spp., and Tegulidae (Appendix A), and by quartz artefacts, and granite cobbles (Figures 5-6).

Excavation of a single $1 \mathrm{~m} \mathrm{x} 1 \mathrm{~m}$ unit (Square A) was undertaken between 5 and 26 May 2013. The square was oriented north and positioned on the area of highest density shell exposure at the top of the ridge overlooking Mangrove Beach. A local datum was established to facilitate mapping 


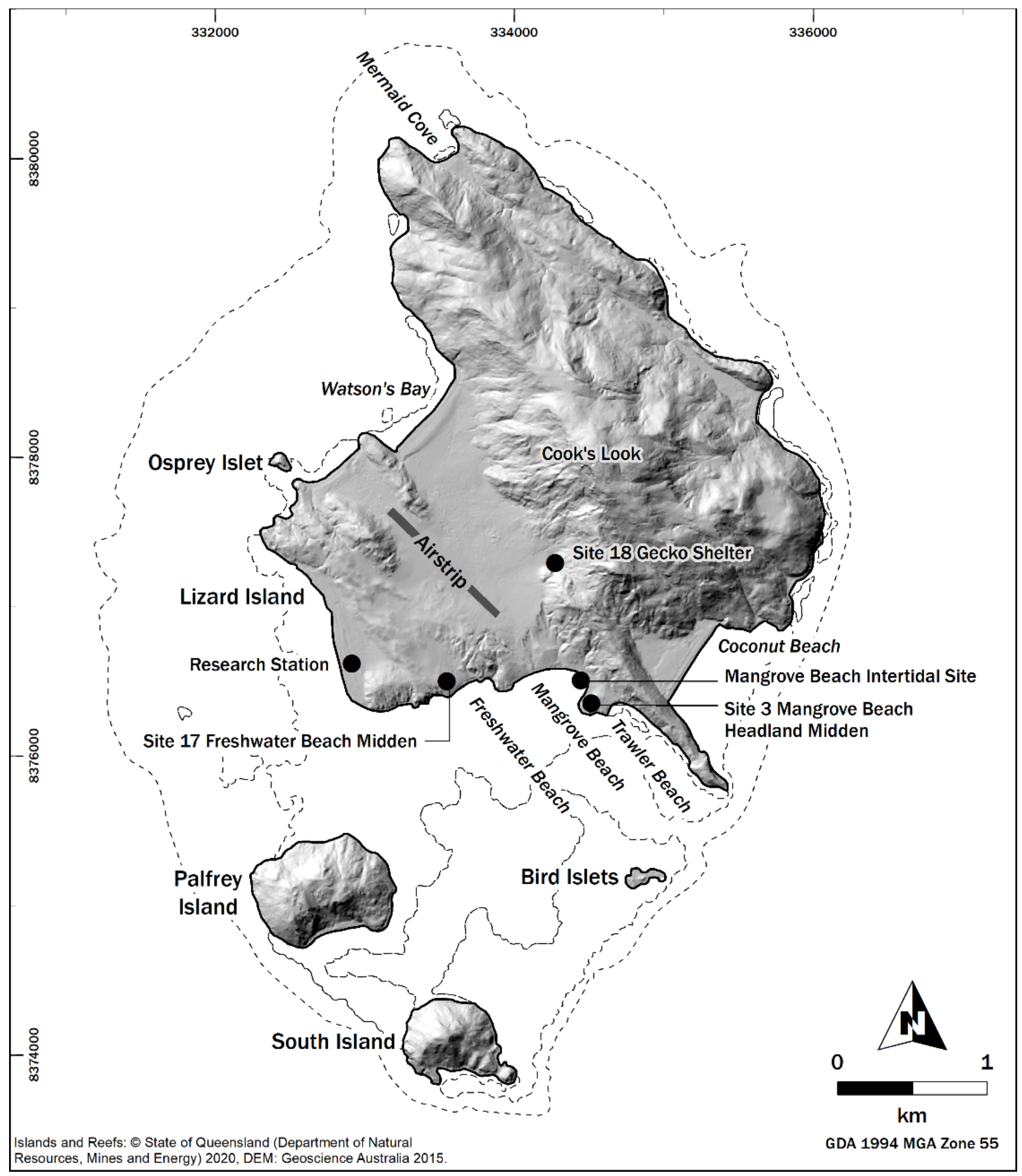

Figure 2. Lizard Island Group, showing the location of Site 3 Mangrove Beach Headland Midden (MBHM) and other archaeological sites and places mentioned in text. The dotted line shows the extent of the reef platform. 


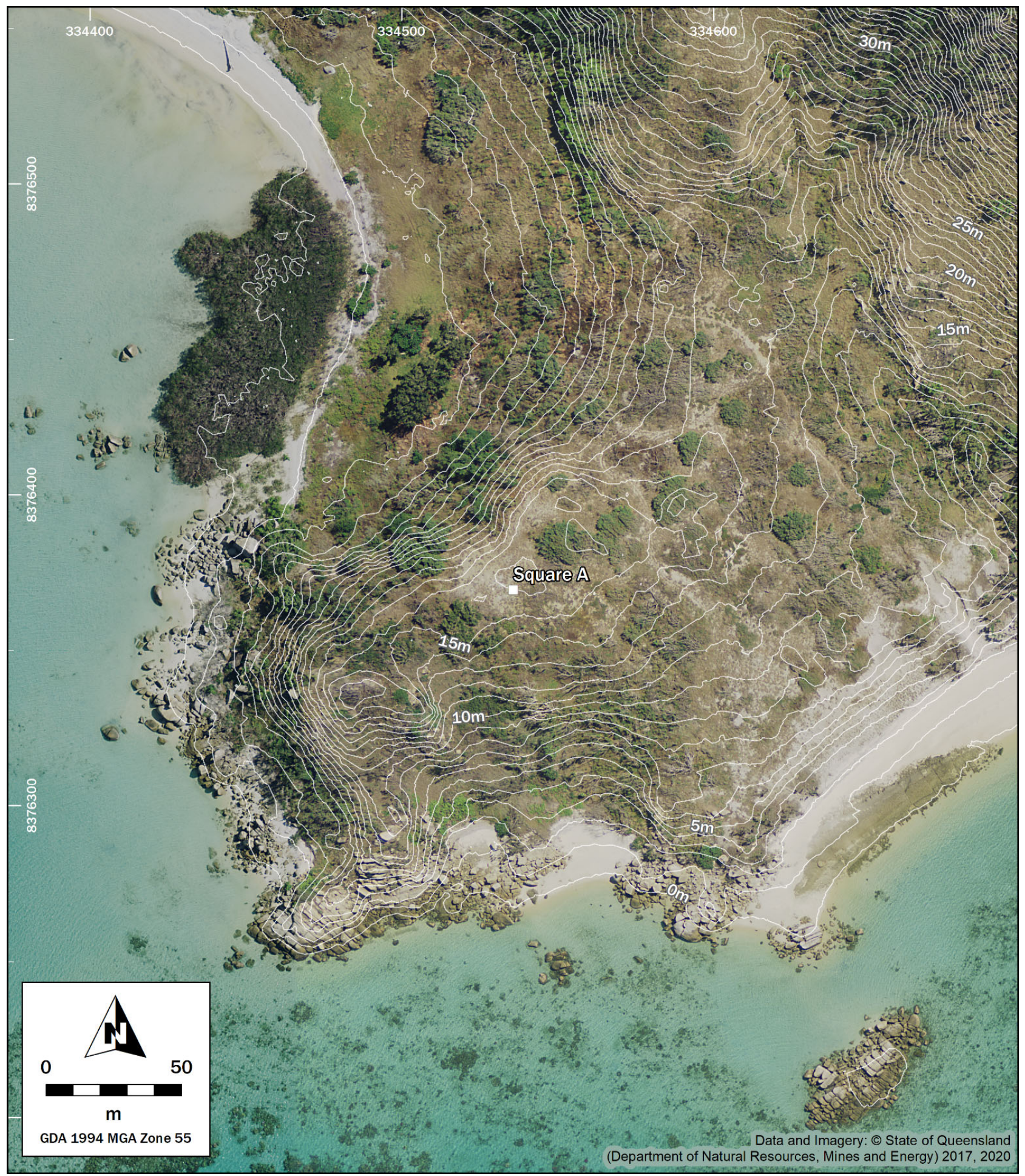

Figure 3. Topographic site map showing the location of Site 3 Mangrove Beach Headland Midden, Square A. 


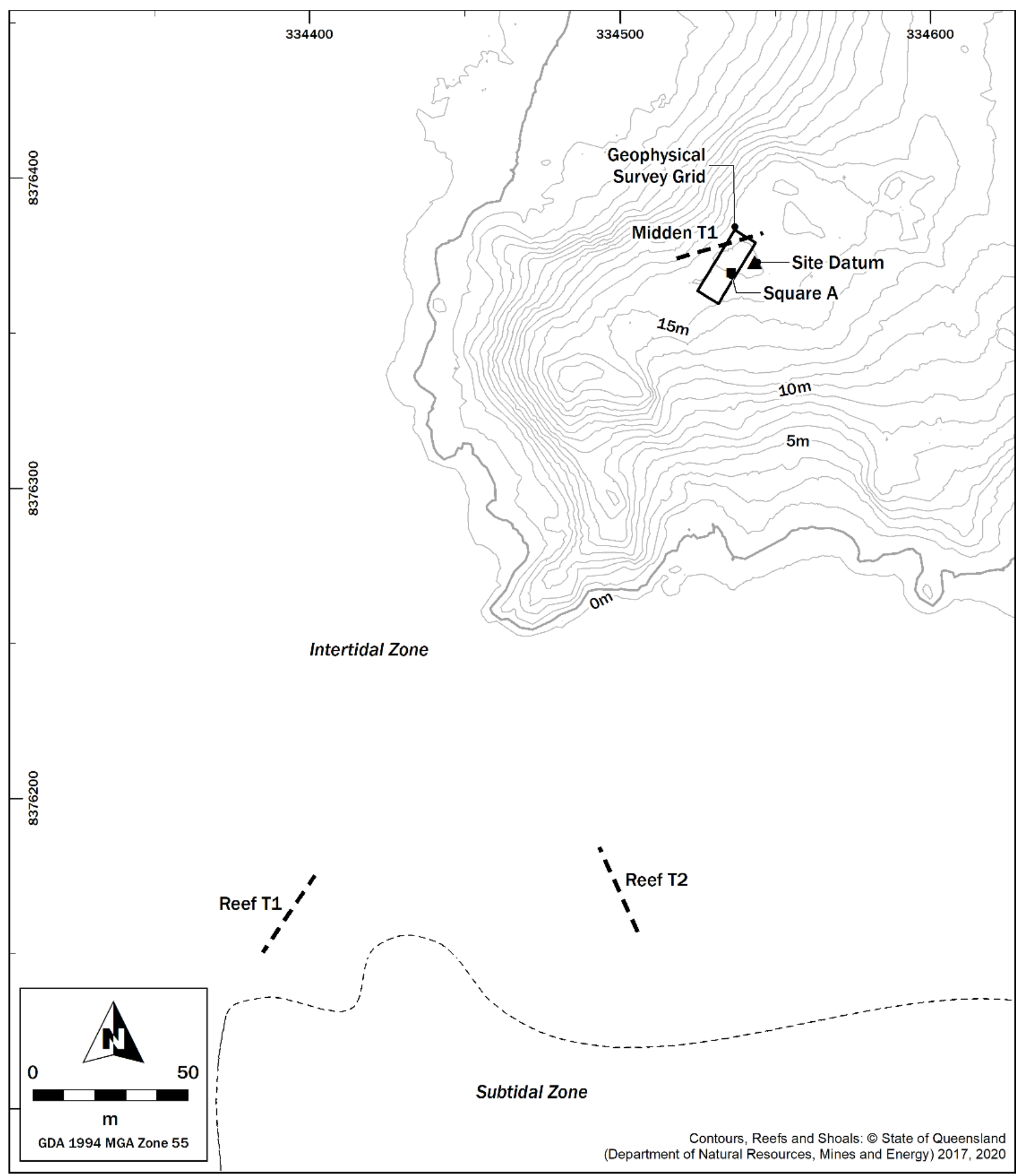

Figure 4. Topographic site map showing location of Site 3 Mangrove Beach Headland Midden, Square A in relation to the site datum, geophysical survey grid, and $T$. maxima transect surveys (Midden T1, Reef T1, and Reef T2). Transect Centrelines were used for the Midden T1, Reef T1, and T2 transects. 


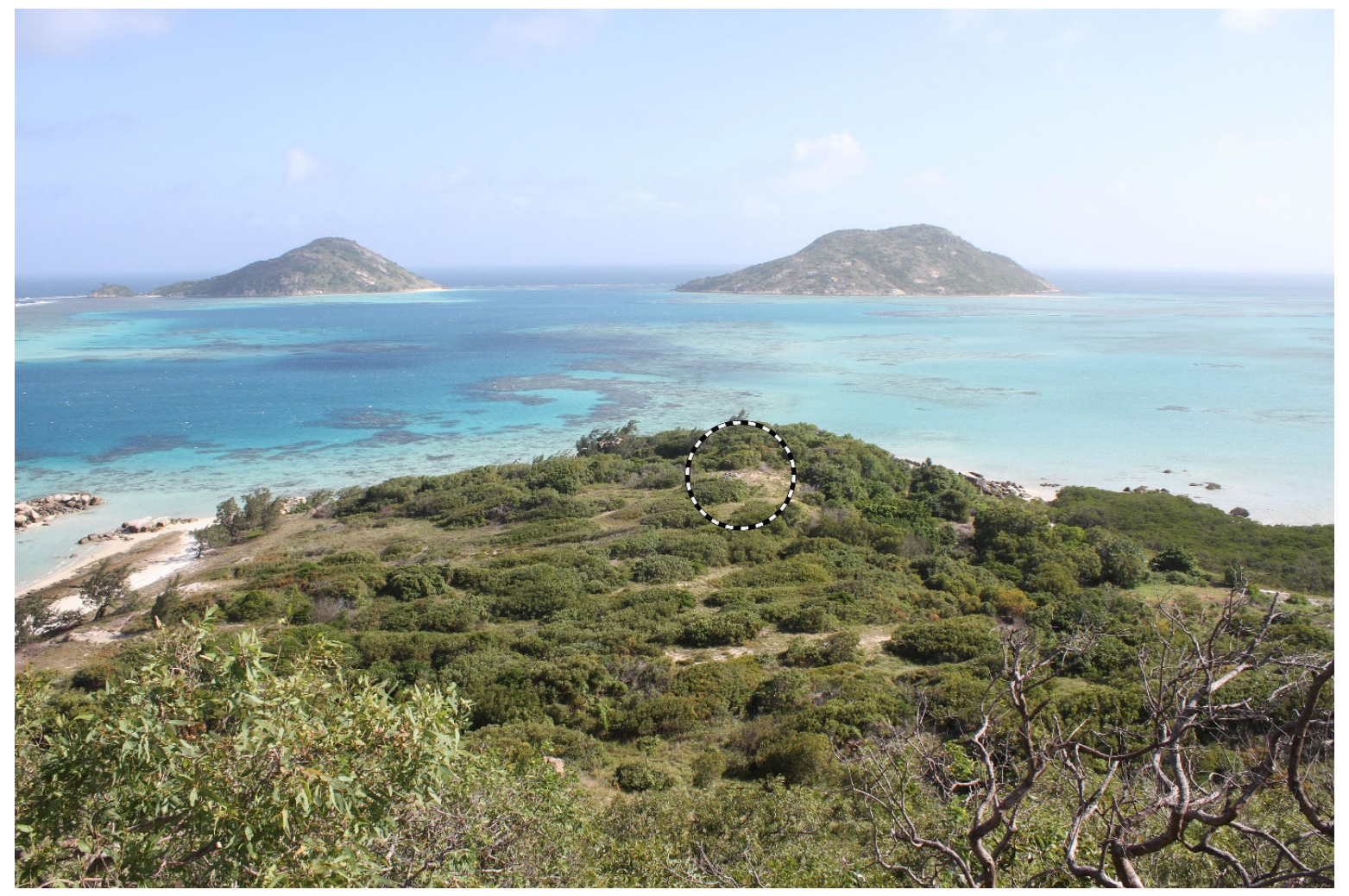

Figure 5. Site 3 Mangrove Beach Headland Midden (indicated by circle), looking towards the expansive reef and South Island (left) and Palfrey Island (right) in the background, facing southwest (Photograph: Sean Ulm, 2013).

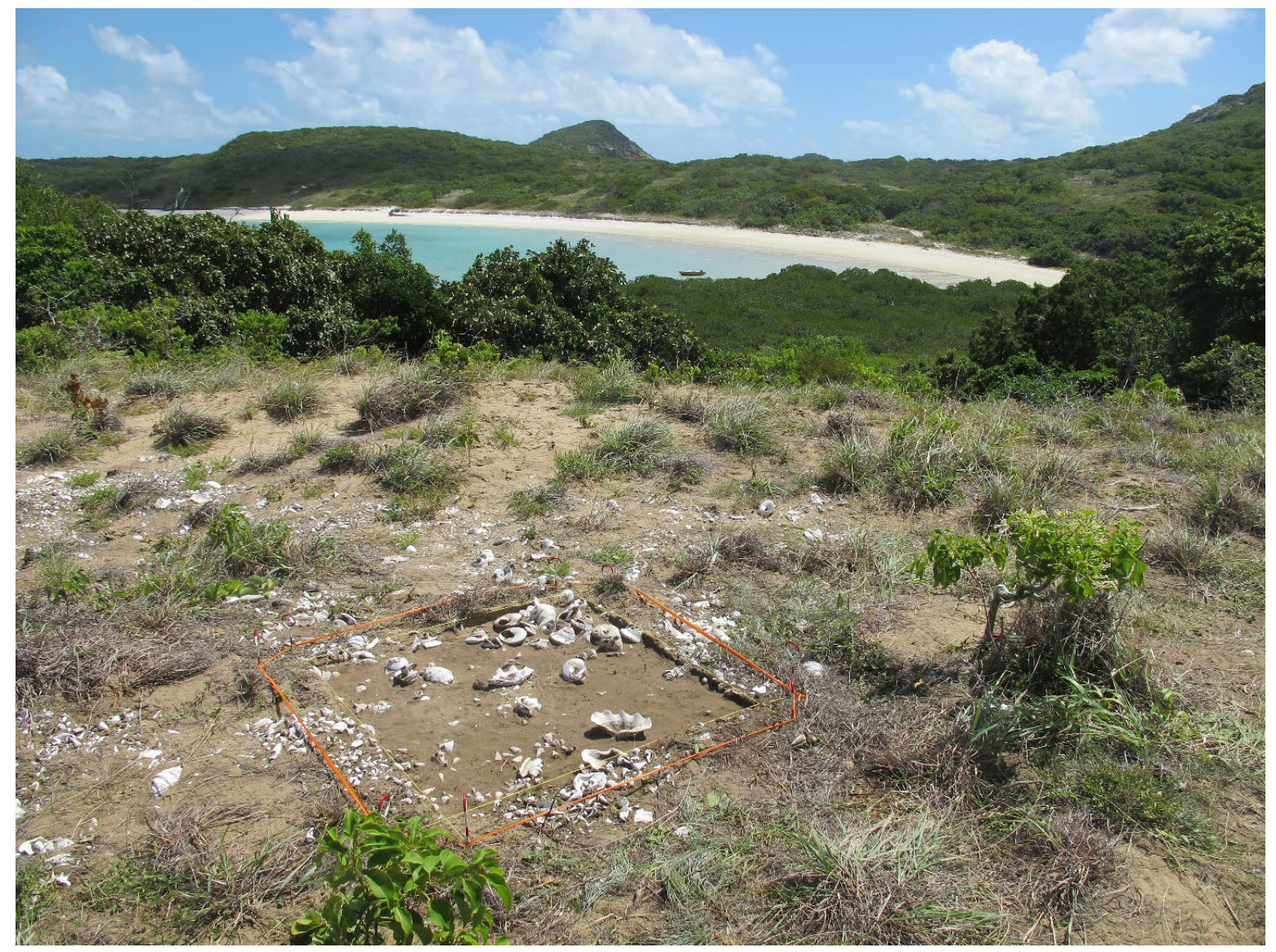

Figure 6. Site 3 Mangrove Beach Headland Midden, looking towards Mangrove Beach, showing excavations in progress, end of XU1 (Square A in foreground), facing west-southwest (Photograph: Ian McNiven, 2013). 
and to record elevations during excavation. Square A was excavated in 59 arbitrary excavation units (XUs), within stratigraphic units (SUs), avoiding mixing between SUs within the same XU where possible. The XUs averaged 2.53 $\mathrm{cm}$ in thickness, and excavations ceased at a maximum depth of $151.74 \mathrm{~cm}$. Using an automatic level and stadia rod, elevations (four corners and centre-point) were recorded at the start and completion of each XU. Finds recovered in situ were recorded three-dimensionally and assigned both an object and field specimen number (see Appendix I). The weight (to the nearest $0.1 \mathrm{~kg}$ ) and volume (to the nearest $0.5 \mathrm{~L}$ ) of material recovered from each XU was measured. All excavated material was dry-sieved through $2.36 \mathrm{~mm}$ mesh in the field, and this retained material and a $100 \mathrm{~g}$ sieved sediment sample collected for each $\mathrm{XU}$, were assigned individual field specimen numbers. Using dry sediments in the field, both $\mathrm{pH}$ readings and soil colour (classified using Munsell Soil Color ${ }^{\circledR}$ Charts) were recorded for each XU. Plan view photographs were captured at the completion of each XU. Excavated section walls were drawn and photographed when excavations were completed. A total of $2211.7 \mathrm{~kg}$ of material was excavated from Square A with a corresponding volume of 1897.9 L. Square A was backfilled with the sieved sediments from the spoil heap located $10 \mathrm{~m}$ northeast of Square A.

\section{Stratigraphy, Cultural Deposit, and Preservation}

The cultural deposit extended to approximately $100-110 \mathrm{~cm}$ below surface. Overall, the deposit was of low density consisting primarily of molluscs and artefactual stone, but also bone and charcoal (Figures 7-8). Square A comprised six SUs (Table 1; Figure 9), which generally consisted of loosely consolidated sands, with numerous roots, and a decreasing proportion of coarse-grained sediments with large visible quartz grains associated with the most recent deposits. The densest concentration of mollusc shell was recovered from the upper section of the deposit, down to a depth of $\sim 30 \mathrm{~cm}$ below the surface (SUs 1-3), whereas artefactual stone was recovered throughout the sequence down to a depth of $\sim 115$ $\mathrm{cm}$ below the surface (SUs 1-5). The lowest 3D-plotted stone artefact was recovered from the top $5 \mathrm{~cm}$ of SU6, but the lowest artefact was recovered from $15 \mathrm{~cm}$ below the SU5/6 boundary. The SU5/6 boundary is diffuse, indicating that there was some movement of sediments from the lower part of SU5 to the top $15 \mathrm{~cm}$ of SU6. No cultural materials were observed in undisturbed SU6 sediments during excavation.

Aside from root growth, there was limited evidence of bioturbation documented during excavation (i.e. no indication of lizard burrows or extensive insect activity). There was good preservation of faunal remains in the top section of the deposit down to $\sim 30 \mathrm{~cm}$ below the surface, particularly of mollusc shell, but small fish bones were also recovered, though they were highly fragmented. The increasingly acidic sediments with depth, particularly in SUs 5-6 (and the lower part of SU4), may account for the reduced representation of bone and mollusc shell in the earliest deposits, especially given stone artefacts were recovered well below the deepest faunal remains. Furthermore, pollen was only preserved in the top section of the deposit, specifically from sediments down to a depth of $\sim 18 \mathrm{~cm}$ below surface (SUs 1-2). Evidence at the site for the most intensive stone artefact discard does correspond with the highest density of recovered mollusc shell and bone down to a depth of $\sim 30 \mathrm{~cm}$ below surface (SUs 1-3).
These trends may indicate a combination of factors influenced discard and preservation of cultural materials through time at the site. For instance, poorer preservation of organics in the earliest occupation phases (SUs 4-5) may be due to comparatively more acidic sediments, which could indicate an underrepresentation of faunal remains associated with initial site use. Factors such as the presence of coarse sedimentary particles and the exposed nature of the site may also have influenced pollen preservation. Conversely, these observed changes in the deposition of cultural materials may relate to specific changes in site use and discard patterns through time, such as an increase in the intensity of occupation at the site. While poor preservation of faunal remains in the lower levels of Square A is a possibility, broader trends in the discard rates of cultural materials suggest these observed changes are probably a result of increased site use during the most recent phase of occupation.

\section{Radiocarbon Dating and Chronology}

Fourteen radiocarbon determinations were obtained using charcoal plotted in situ during excavation of the site $(n=8)$ and Anadara antiquata specimens $(n=6)$ collected from across the surface of the site (Table 2). The samples were processed at the University of Waikato Radiocarbon Dating Laboratory. Radiocarbon ages were calibrated using OxCal 4.1.3 (Bronk Ramsey 2009) and the IntCal13 calibration dataset for charcoal samples, and the Marine13 calibration dataset for marine shells (Reimer et al. 2013), using a $\Delta \mathrm{R}$ of $12 \pm 10{ }^{14} \mathrm{C}$ years (Ulm 2006). All calibrated ages are reported at the $95.4 \%$ probability distribution.

Dates for the surface of the site are tightly constrained, ranging from 580 to $530 \mathrm{cal} \mathrm{BP}$. In Square A, dates range from 680 cal BP in XU3 to 4040 cal BP (charcoal) in XU44. The base of the cultural deposit is around the interface of SUs 5 and 6, with the stone artefact recovered from XU45 (upper half of SU6) the earliest evidence of cultural activity at the site, suggesting basal cultural material at the site dates to shortly before $\sim 4000$ cal BP. The site appears to not to have been used in the last 500 years, except for some metal fragments recovered near the surface that are attributed to recent tourist visitation. Age-depth relationships between and slightly beyond these radiocarbon ages were used to define 250-year analytical units between 0 and $5000 \mathrm{cal} \mathrm{BP}$.

\section{Analytical Methods \\ Geophysical Survey}

A combination of ground-penetrating radar (GPR) and magnetic gradiometry were employed to conduct geophysical surveys at Site $3 \mathrm{MBHM}$ in 2018. Magnetic gradiometry measures the strength or alteration of the Earth's magnetic field across a targeted area, and can locate iron-rich material below the ground surface, including burnt features, metal, and iron-rich soil (Aspinall et al. 2008; Clark 1996; Gaffney and Gater 2003; Witten 2006). GPR transmits electromagnetic energy in the form of radar waves into the ground, and when these waves encounter differences in the soil (e.g. air voids, stone, or a differential moisture content), a reflection occurs, which is received and recorded (Bevan 1998; Conyers 2009, 2012). GPR was selected as it provides both horizonal and vertical spatial information and facilitates the production of three-dimensional images of the subsurface. It was anticipated that GPR would potentially identify the depth of the buried shell deposits and the underlying bedrock. 


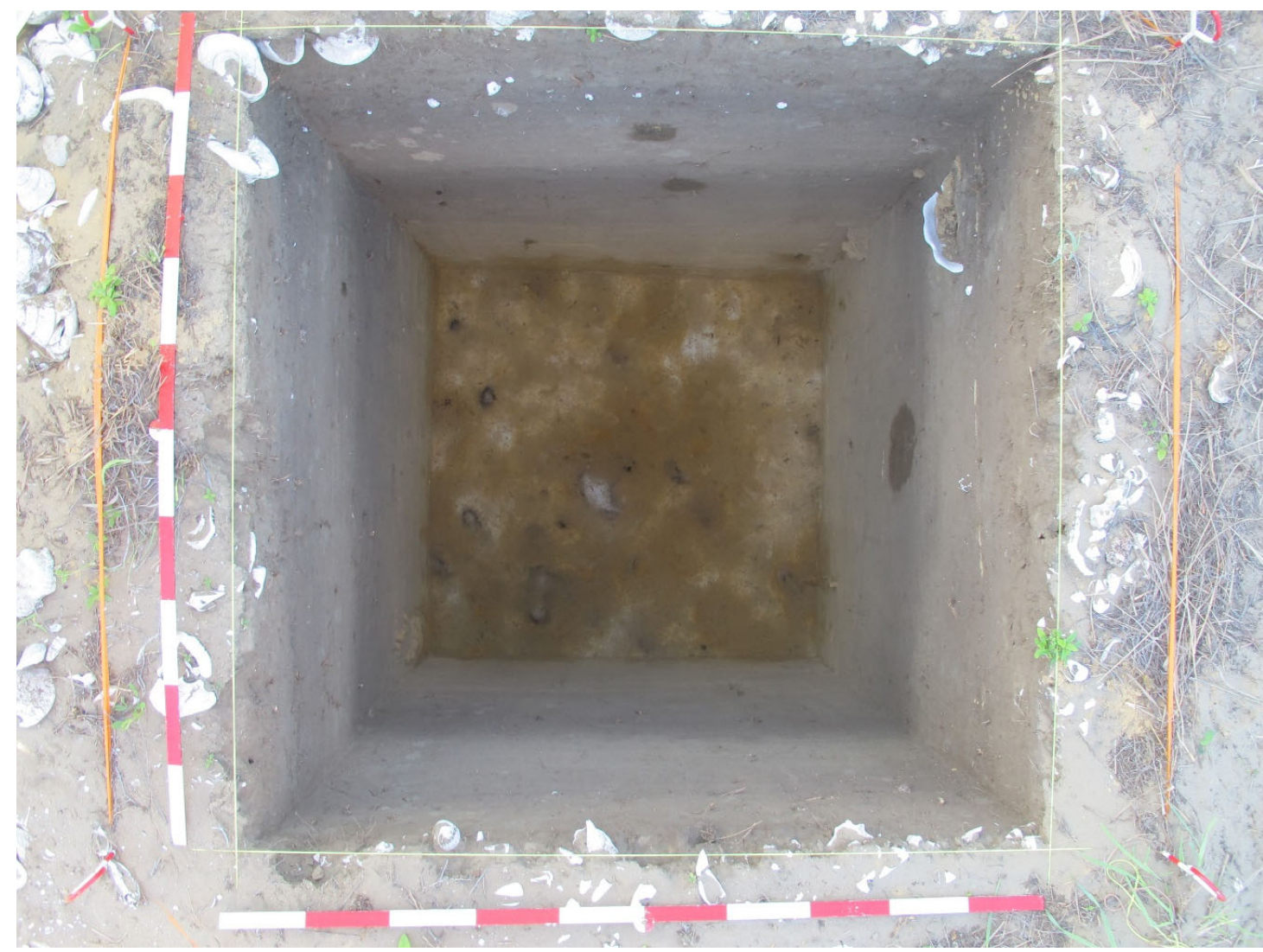

Figure 7. Site 3 Mangrove Beach Headland Midden, Square A at end of excavation, plan view, facing north (Photograph: Ian McNiven, 2013).

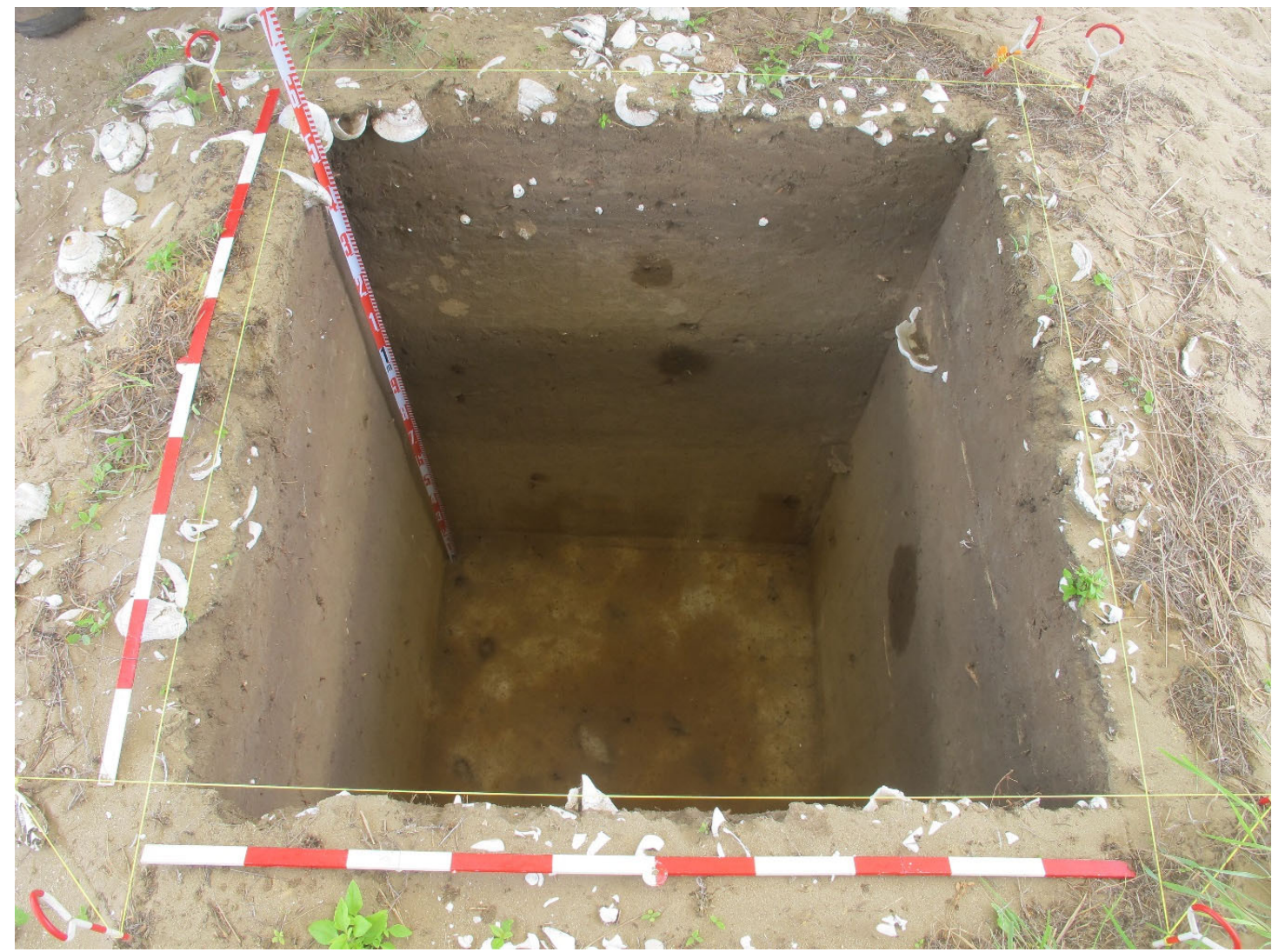

Figure 8. Site 3 Mangrove Beach Headland Midden, Square A at end of excavation showing Stratigraphic Units (SUs), facing north (Photograph: Ian McNiven, 2013). 


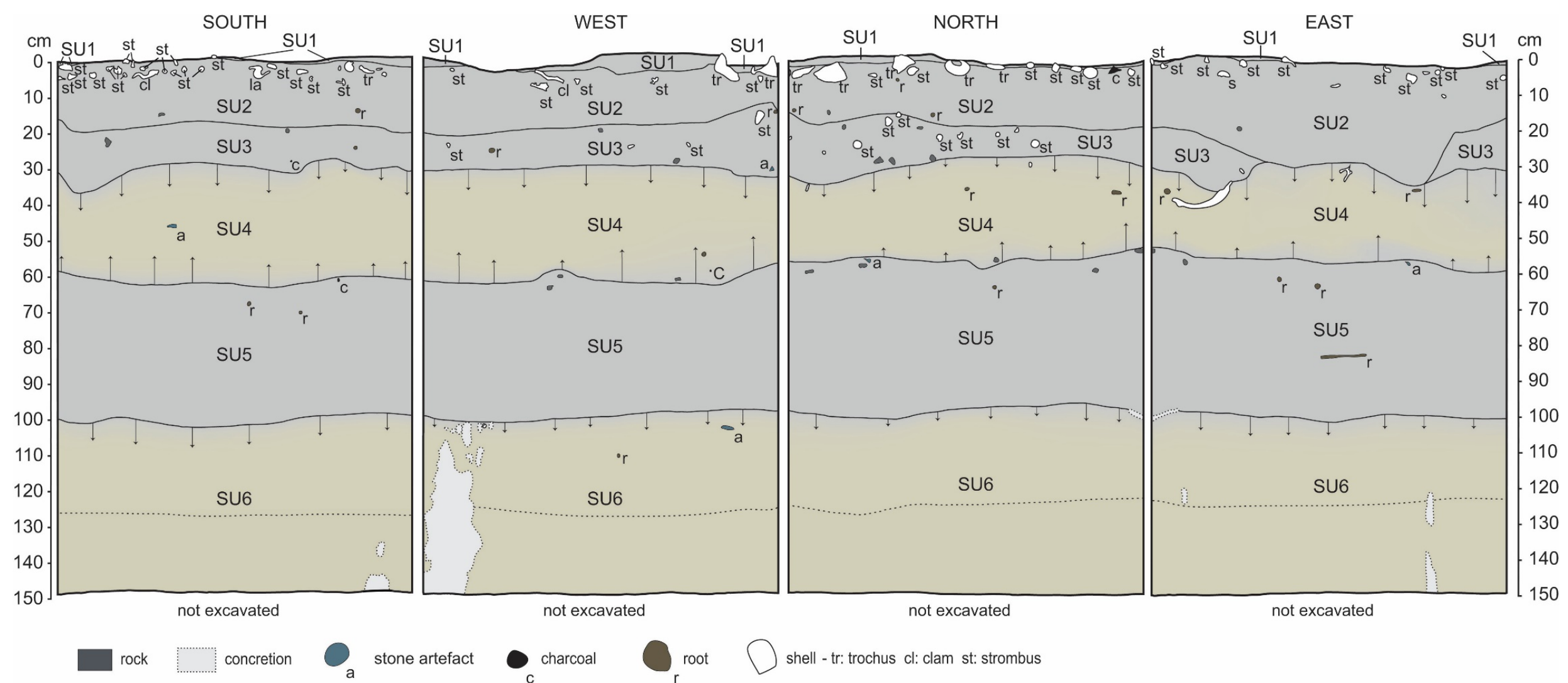

Figure 9. Section drawing of Site 3 Mangrove Beach Headland Midden, Square A, divided into six Stratigraphic Units (SUs) (Original section drawing by Ian McNiven and Sean UIm, 2013). 
Table 1. Stratigraphic Unit (SU) descriptions, Site 3 Mangrove Beach Headland Midden, Square A.

\begin{tabular}{|c|c|}
\hline SU & Description \\
\hline 1 & $\begin{array}{l}\text { Loosely consolidated yellow-brown (10YR 4/6) fine sands, surface grasses and rootlets. Shellfish dominated by } R . \text { nilotica and } C \text {. } \\
\text { luhuanus. SU1 is } 0-4 \mathrm{~cm} \text { below the surface and the interface with SU2 is abrupt and distinct. Sediments are alkaline }(9.0 \mathrm{pH}) \text {. }\end{array}$ \\
\hline 2 & $\begin{array}{l}\text { Partly consolidated brown (10YR 4/6-4/3) fine sands. Numerous fibrous rootlets and occasional larger roots up to } 5 \mathrm{~mm} \text { in diameter. } \\
\text { High concentration of shell between } 1 \mathrm{~cm} \text { and } 6 \mathrm{~cm} \text { below the surface comprised of Tridacna spp., R. nilotica, and C. luhuanus. SU2 } \\
\text { is } 1-35 \mathrm{~cm} \text { below the surface and the transition to SU3 ranges from distinct to diffuse. Towards the centre of the east section SU2 } \\
\text { sediments appear to directly rest on the surface of SU4 sediments. Some mottling of grey sands. Sediments are neutral (6.0-7.5 pH). }\end{array}$ \\
\hline 3 & $\begin{array}{l}\text { Darker brown }(10 \mathrm{YR} 4 / 3-4 / 4) \text { partly consolidated fine sands. An increase in shell comprised predominantly of } C \text {. luhuanus. Fewer } \\
\text { fibrous roots compared to SU2. Occasional larger roots up to } 5 \mathrm{~mm} \text { in diameter continue. SU3 is } 12-37 \mathrm{~cm} \text { below the surface and } \\
\text { the transition to SU4 is reasonably distinct; however, some diffusion of SU3 sediments into the upper sections of SU4. Sediments } \\
\text { are neutral-acidic }(5.5-7.5 \mathrm{pH}) \text {. }\end{array}$ \\
\hline 4 & $\begin{array}{l}\text { Lighter grey-brown (10YR 3/3-5/3). A little less consolidated than SU3. Fine sands, but with occasional coarse fraction with larger } \\
\text { quartz grains visible. Scattered small roots, but some larger roots }>1 \mathrm{~cm} \text { in diameter. Interface with SU5 is reasonably distinct; } \\
\text { however, there is some penetration of the darker sediments of SU5 into the lower part of SU4. The unit is } 27-64 \mathrm{~cm} \text { below the surface } \\
\text { with only a few } R \text {. nilotica in section of SU4. Patches of light grey and yellow sand mottling. Sediments are neutral-acidic (5.5-6.0 } \\
\mathrm{pH}) \text {. }\end{array}$ \\
\hline 5 & $\begin{array}{l}\text { Darker brown (10YR 4/3-5/3), but grades with depth to a slightly lighter coloured sediment. Scattered roots }>1 \mathrm{~cm} \text { in diameter. Fine } \\
\text { sediments but with a coarse-grained fraction. The coarse fraction has a higher density in the lower } 10 \mathrm{~cm} \text { of the unit. No shellfish in } \\
\text { section. Occasional nodules of degrading granite. SU5 is } 52-103 \mathrm{~cm} \text { below the surface and the interface with SU6 is diffuse. } \\
\text { Sediments are neutral-acidic }(5-6.5 \mathrm{pH}) \text {. }\end{array}$ \\
\hline 6 & $\begin{array}{l}\text { Yellow-brown sands (10YR 5/3-6/6), but heavily mottled in the lower half with patches of yellow and fine, white sands. Some } \\
\text { penetration of coarse-grained sediments from the basal part of SU5 into the top } 5 \mathrm{~cm} \text { of SU6. Partly consolidated orange } \\
\text { sandstone/ironstone concretions common in lower half. Occasional roots }>1 \mathrm{~cm} \text { in diameter. Lowest plotted artefact in east section } \\
\text { at the top of SU6, but in mixing interface zone with SU5. SU6 is c. } 96-125 \mathrm{~cm} \text { below the surface. No cultural materials were observed } \\
\text { in undisturbed SU6 sediments during excavation. Sediments are acidic }(4.5-5.5 \mathrm{pH}) \text {. }\end{array}$ \\
\hline
\end{tabular}

Table 2. Radiocarbon determinations for Site 3 Mangrove Beach Headland Midden, Square A. Dates were calibrated using OxCal 4.1.3 (Bronk Ramsey 2009). For wood charcoal dates, the IntCal13 calibration dataset was used and for marine shell, the Marine13 calibration dataset (Reimer et al. 2013), with a $\Delta R$ of $12 \pm 10{ }^{14} \mathrm{C}$ years for marine samples (Ulm 2006). Calibrated ages are rounded to the nearest 10 years. Note the $A$. antiquata samples were collected from the surface of the site beyond Square A. AMS= Accelerator Mass Spectrometry. LSC=Liquid Scintillation Counting.

\begin{tabular}{|c|c|l|l|l|l|l|l|c|c|}
\hline Lab. No. & SU & XU & $\begin{array}{c}\text { Depth } \\
\mathbf{( c m )}\end{array}$ & \multicolumn{1}{|c|}{ Sample } & Method & $\begin{array}{c}\mathbf{\delta}^{\mathbf{1 3}} \mathbf{C} \\
\mathbf{( \% )}\end{array}$ & $\begin{array}{c}{ }^{\mathbf{1 4}} \mathbf{C} \text { Age } \\
\text { (years BP) }\end{array}$ & $\begin{array}{c}\text { Calibrated } \\
\text { Age BP } \\
\mathbf{9 5 . 4 \%} \\
\text { Prob.) }\end{array}$ & $\begin{array}{c}\text { Median } \\
\text { Calibrated } \\
\text { Age BP }\end{array}$ \\
\hline Wk-37131 & - & - & 0 & A. antiquata & AMS & $1.7 \pm 0.1$ & $948 \pm 25$ & $490-610$ & 530 \\
\hline Wk-37132 & - & - & 0 & A. antiquata & LSC & $1.7 \pm 0.1$ & $965 \pm 27$ & $500-620$ & 550 \\
\hline Wk-37129 & - & - & 0 & A. antiquata & AMS & $1.7 \pm 0.1$ & $981 \pm 25$ & $510-620$ & 560 \\
\hline Wk-37133 & - & - & 0 & A. antiquata & LSC & $1.8 \pm 0.1$ & $985 \pm 30$ & $510-630$ & 570 \\
\hline Wk-37128 & - & - & 0 & A. antiquata & LSC & $0.6 \pm 0.1$ & $1002 \pm 31$ & $520-640$ & 580 \\
\hline Wk-37130 & - & - & 0 & A. antiquata & AMS & $1.8 \pm 0.1$ & $1008 \pm 25$ & $530-640$ & 580 \\
\hline Wk-38696 & 2 & 3 & $5.1-7.5$ & charcoal & AMS & - & $747 \pm 21$ & $670-720$ & 680 \\
\hline Wk-38697 & 3 & 10 & 23.3 & charcoal & AMS & - & $1836 \pm 21$ & $1710-1820$ & 1770 \\
\hline Wk-38698 & 4 & 16 & 39.9 & charcoal & AMS & - & $3144 \pm 22$ & $3270-3440$ & 3370 \\
\hline Wk-38699 & 4 & 20 & 50.0 & charcoal & AMS & - & $3151 \pm 21$ & $3280-3450$ & 3380 \\
\hline Wk-38700 & 4 & 24 & 60.6 & charcoal & AMS & - & $3149 \pm 21$ & $3270-3450$ & 3380 \\
\hline Wk-38701 & 5 & 27 & 66.4 & charcoal & AMS & - & $3148 \pm 21$ & $3270-3450$ & 3380 \\
\hline Wk-38702 & 5 & 30 & 72.4 & charcoal & AMS & - & $3136 \pm 22$ & $3260-3440$ & 3370 \\
\hline Wk-38703 & 6 & 44 & 108.8 & charcoal & AMS & - & $3689 \pm 21$ & $3930-4090$ & 4040 \\
\hline
\end{tabular}


The survey grid was $8 \mathrm{~m} \times 20 \mathrm{~m}$ for the magnetic gradiometer and extended to $8 \mathrm{~m}$ x $23 \mathrm{~m}$ for the GPR (Figure 4 ). The magnetic gradiometer data were collected using a Bartington Instruments Fluxgate Grad601-2. This instrument utilises two pairs of magnetometers that are stacked vertically $1 \mathrm{~m}$ apart to provide a measure of the magnetic gradient at each measuring station. Gradiometers record very subtle $(0.1$ nT) fluctuations in the local magnetic field. The instrument was set up to record data eight times per metre with $0.5 \mathrm{~m}$ spaced survey transects $\left(16\right.$ samples $\left./ \mathrm{m}^{2}\right)$. Data were processed using TerraSurveyor version 3.0.25.1. Processing was limited to de-striping to remove abnormal high/low readings, highpass filtering, and interpolation to equalise pixel size to 0.125 $\mathrm{m}$ by $0.125 \mathrm{~m}$. The processed data were exported and imported into Surfer for cartography.

A Geophysical Survey Systems, Inc. (GSSI) SIR-3000, $400 \mathrm{MHz}$ antenna and a model 620 survey wheel were used to collect the GPR data. Sixteen-bit data were collected with a $40 \mathrm{nS}$ time window, 512 samples/scan, and with 25 scans/metre. Transects were spaced every $0.5 \mathrm{~m}$. Using GPRSLICE v7.0, data were processed (time zero correction, background removal and bandpass filter) and converted into amplitude slice-maps and reflection profiles. A constant velocity $(\mathrm{m} / \mathrm{nS})$ model was used in the hyperbola search menu. The hyperbola fitting function estimated the relative dielectric permittivity, which is calculated from the two-way travel time to depth, and this facilitated the production of time slices and provided an estimated depth of the data (Goodman and Piro 2013; Jacob and Urban 2015). These generated depth estimates were compared to the excavation data to create amplitude slice-maps. An overlay analysis computed in GPRSLICE (see Goodman and Piro 2013) using depths from 28$59 \mathrm{~cm}$ was also created to highlight the anomalies across the site by depth. This supports interpretation of the reflection features as the amplitude slice levels are overlaid to show the strongest reflectors at specified depths.

\section{Laboratory Protocols}

Sediment samples were collected from each XU $(n=59)$ and sent to the University of Queensland for analysis of magnetic susceptibility, identification of pollen/spores, and assessment of micro-charcoal concentration throughout the sequence. All dry-sieved residues were transported to the James Cook University (JCU) Tropical Archaeology Research Laboratory (TARL) for analysis. Each XU was wet-sieved through 2.36 $\mathrm{mm}$ mesh, air-dried, and sorted into major categories mollusc, bone, charcoal, coral, other organic (i.e. noncarbonised roots, litter, seeds, and insect remains), metal, pumice, non-artefactual stone, artefactual stone, and ochre. Specialist analysis was conducted on all recovered materials and sediments, and detailed analytical protocols are outlined below.

\section{Magnetic Susceptibility Analysis}

Magnetic susceptibility is the degree to which magnetisation can be induced in a sample in the presence of a magnetic field (Dalan et al. 2017; Thompson and Oldfield 1986). Cultural and natural processes have the capacity to modify magnetic mineralogy, for example, the influence of fire, pedogenesis and chemical weathering (Dalan and Banerjee 1998; Ellwood et al. 1997; Herries and Fisher 2010; Linford et al. 2005). People tend to influence magnetic mineralogy through increased inputs of organic matter and the exposure of soils to high temperatures through burning events (Mullins 1974). In an archaeological context, soil magnetic susceptibilities tend to be enhanced and at the site-level as variability between site features and occupation layers can be observed; consequently, this technique is valuable for assessing changes in landscape use through time (Dalan et al. 2017; Tite and Mullins 1971).

All XU sediment samples $(n=59)$ from Square A were packed in small non-magnetic Althor P-15 boxes (5.28 cc volume). Magnetic susceptibility measurements were recorded using a Bartington MS2B dual frequency sensor. Repeat measurements were recorded for each sediment sample and averaged. Mass $(\chi)$ and volume ( $\kappa)$ low-field magnetic susceptibility measurements were recorded, as well as the frequency dependence of susceptibility $\left(\chi_{\mathrm{fd}}\right)$ for each sample. Frequency dependence is the percent difference in susceptibility measured at $460 \mathrm{~Hz}\left(\chi_{\mathrm{lf}}\right)$ and $4600 \mathrm{~Hz}\left(\chi_{\mathrm{hf}}\right)$ frequencies, and is expressed as a relative loss of susceptibility $\left(\chi_{\mathrm{fd}}=\chi_{\mathrm{lf}}-\chi_{\mathrm{hf}}\right)$ or percentage loss of the low frequency value $\left(\chi_{\mathrm{fd}} \%=100 \times\left[\chi_{\mathrm{lf}}-\chi_{\mathrm{hf}} / \chi_{\mathrm{lf}}\right]\right)$ (Dearing et al. 1996; Maher and Taylor 1988). Calculation of $\chi_{\mathrm{fd}}$ and $\chi_{\mathrm{fd}}(\%)$ track the content of ultrafine or superparamagnetic (SP) grains $(>0.03 \mu \mathrm{m})$, which are useful for documenting burned or welldeveloped soils (Dalan and Banerjee 1998; Dearing et al. 1996).

\section{Pollen and Micro-Charcoal Analysis}

Pollen, spore, and micro-charcoal samples from Square A comprised $1 \mathrm{~g}$ of sediment from the $<2.36 \mathrm{~mm}$ fraction collected per XU.

Sample preparation followed techniques developed by van der Kaars (1991) and detailed in Moss et al. (2019). Chemical and sieving preparations were selected to disaggregate then progressively remove bulk sand/gravel, separate organic from inorganic (mineral) fine-fractions, and finally stain the pollen/spores (combining Sodium pyrophosphate, $180-\mu \mathrm{m}$ and $8-\mu \mathrm{m}$ screen mesh, heavy liquid treatment, and Acetolysis treatments). Lycopodium spike additions served relative concentration calculations of both pollen/spores and microcharcoal. All samples were mounted in glycerol and examined at $\times 400$ using a Leica compound light microscope. The pollen sum consisted of two completely counted slides, while the charcoal analysis involved counting all black angular fragments $>5 \mu \mathrm{m}$ along three evenly spaced transects across all XUs. The results of the palynological and charcoal analysis are presented graphically using the TGView software (Grimm 2004).

\section{Faunal Identification and Quantification Protocols}

Fish, turtle, and molluscan remains were identified to the lowest taxonomic level using comparative collections housed at the JCU TARL (see Tomkins et al. 2013, for a description of the fish reference collection, but note that additional specimens have since been added). Reference manuals were also used for molluscan (Carpenter and Niem 1998; Eichhorst 2016; Hinton 1972; Huber 2010; Jarrett 2011), fish (Bellwood 1994; Bellwood and Schultz 1988; Berkovitz and Shellis 2016), and turtle (Wyneken 2003) identifications. All bone and mollusc fragments were considered for taxonomic identification, with genus- and species-level identifications assigned conservatively to avoid over-identification (Harris et al. 2016; Wolverton 2013). All faunal remains were 
quantified using number of identified specimens (NISP), minimum number of individuals (MNI), and weight (g). For vertebrate remains, MNI values were calculated following standard zooarchaeological protocols (Grayson 1984; Lambrides and Weisler 2016; Lyman 2008; Reitz and Wing 2008) and for molluscs following Harris et al. (2015). An MNI of 1 was assigned in the absence of an NRE to indicate presence only when the specimen was taxonomically identifiable and the effects of aggregation could be avoided (e.g. Attenbrow 1992; Faulkner et al. 2019; Giovas 2009; Jerardino and Marean 2010). The adoption of these quantification methods allows direct comparison between vertebrate and invertebrate taxonomic abundance data as MNI values were consistently calculated using the most frequently occurring non-repetitive element (NRE) according to periodised 250-year time intervals.

For the mollusc assemblage taxonomic heterogeneity was measured using NTAXA, Shannon-Wiener index of diversity $\left(H^{\prime}\right)$, Shannon's evenness (E), Simpson's dominance ( $\left.1-D\right)$, and Fisher's $\alpha$. All measures were calculated using MNI values and were determined using mutually exclusive taxonomic categories (or non-overlapping taxa) in accordance with standard quantitative zooarchaeology protocols (e.g. Giovas 2018; Lyman 2008). See Faith and Du (2017), Harris and Weisler (2018), Lambrides et al. (2018), Lyman (2008), Magurran (2004), and Smith and McNiven (2019) for definitions of terms and approaches for using these measures of taxonomic heterogeneity to analyse zooarchaeological assemblages. NTAXA values provide an assessment of taxonomic richness. High $H^{\prime}$ values broadly indicate greater species diversity and richness, with values generally falling below a theoretical maximum of 5 . E and $1-D$ values that are closer to 0 indicate an assemblage dominated by a single taxon, and rich and even assemblages will have values closer to 1 (Lyman 2008). Fisher's $\alpha$ provides an assessment of diversity that is independent of sample size by tracking taxa represented by single individuals, unlike NTAXA and Shannon's indices (Faith 2013; Hayek and Buzas 2010). Measures of taxonomic heterogeneity were not calculated for the fish and turtle assemblages due to insufficient sample sizes. All statistical analyses were completed using PAST, version 4.01 (Hammer et al. 2001).

Morphometric analysis of the dominant molluscan species was undertaken in a previous study, with lip thickness of Conomurex luhuanus $(n=224)$ and base diameter of Rochia nilotica $(n=38)$ measured to determine size-at-age habitat preferences (see Ulm et al. 2019 for a detailed description of the sample and analytical methods). The maximum shell length of Tridacna maxima specimens (left valve only) from both the archaeological deposit and a closely associated modern reef population were measured to provide a gross comparison of population age-structure of this species through time. See Chan et al. (2008:Figure 1) for an illustration of Tridacna spp. shell length landmarks. $T$. maxima specimens located on the surface of Site $3 \mathrm{MBHM}$ and within a $30 \mathrm{~m} \times 4 \mathrm{~m}$ transect (Midden T1) situated across the centre of the site were measured $(n=74)$ (Figure 4$)$, as well as specimens recovered during the excavation of Square A $(n=10)$. During November, 2016, live T. maxima specimens $(n=115)$ located along the reef flat and situated near the southwest extent of the site were measured within two underwater transects (Reef T1 and T2) that were $30 \mathrm{~m} \mathrm{x}$ $2 \mathrm{~m}$ in size. T. maxima sexual maturity can be indicated by a shell length of approximately $150 \mathrm{~mm}$, however, in some instances maturity is reached when the individual is significantly smaller, and geography and local ecological factors have variable influences on maturation (e.g. Chambers 2007; Gilbert et al. 2006; Jameson 1976). Given most individuals will be sexually mature by $150 \mathrm{~mm}$ and larger, to be conservative, specimens with maximum lengths equal to or larger than $150 \mathrm{~mm}$ were categorised as adult, and those smaller than $150 \mathrm{~mm}$ categorised as juvenile. This approach facilitated a gross comparison between the representation of adult and juvenile $T$. maxima individuals in the sampled archaeological and modern reef populations.

\section{Stone Artefact Analysis}

All recovered stone artefacts were analysed. Attributes recorded - raw material, type (e.g. flake, core, etc.), fragment category (e.g. complete, left, right, distal, marginal, etc.) and flake dimensions (length, width, thickness, elongation, and angle) - were used to document changes in lithic discard rates and raw material usage through time at the site, following methods described by Clarkson (2007), McNiven et al. (2014), and O'Connor et al. (2014).

\section{Results}

Overall, $36.49 \mathrm{~kg}$ of material was retained in the $2.36 \mathrm{~mm}$ mesh sieve, which is $1.7 \%$ of the total recovered sediment and material excavated, broadly suggesting a low-density cultural deposit. See Appendix B for a summary of excavation data and retained materials. The assemblage was dominated by molluscan remains $(55.1 \%, 20,101 \mathrm{~g})$ and non-artefactual stone $(43.1 \%, 15,719 \mathrm{~g})$, with $>2.0 \%$ of the deposit $(673.47 \mathrm{~g})$ comprising bone, charcoal, coral, other organic, metal, pumice, artefactual stone, and ochre. While the recovered stone artefacts weighed only $198.32 \mathrm{~g}$, there were 333 individual artefacts identified, averaging $0.60 \mathrm{~g}$ each. The pumice $(81.39 \mathrm{~g})$ was examined for signs of cultural modification (e.g. grinding facets) and determined not to be culturally introduced into the site. Metal (3.47 g) was recovered from XUs 1 and 2 only (up to $5.1 \mathrm{~cm}$ below surface [cmbs], 750-500 cal BP), suggesting some post-depositional disturbance at the surface of the site. This is consistent with the pollen and micro-charcoal records from the site, which indicate the possibility of missing sediments at the surface of the site. The entire assemblage was re-analysed for this study, and the results presented here supersede those in Aird (2014) and Ulm et al. (2019).

\section{Geophysical Survey Outcomes}

Gradiometer data revealed two magnetic anomaly types including a large positive (black) response in the northeast extent of the surveyed area, and a coupled positive and negative (white) response (Figure 10). The large positive anomaly was attributed to the metal star picket (site datum), which is located outside of the surveyed area, but still captured by the gradiometer. The coupled anomaly is a fragment of metal, and this is consistent with other metal fragments recovered from the site surface (XUs 1-2) during Square A excavation. The GPR data revealed several linear high-amplitude reflections throughout the survey area, most notably in those areas of the site that were topographically lower and towards the edges of the shell midden and surveyed area (Figure 10). 

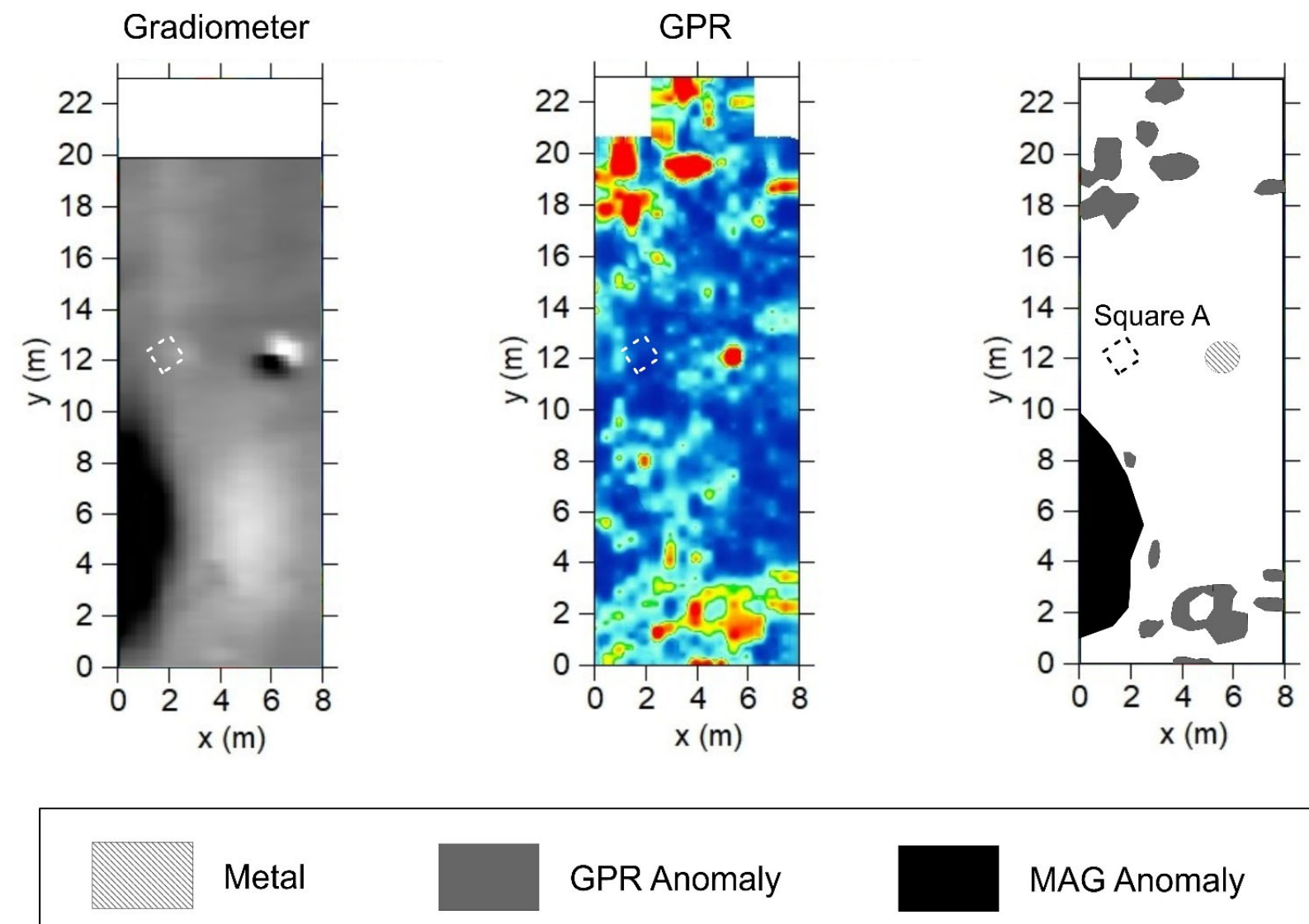

GPR Anomaly

MAG Anomaly

Figure 10. Magnetic gradiometer (left) and GPR (centre) datasets with the interpretations (right) for Site 3 Mangrove Beach Headland Midden. Note the square indicates the position of Square A, and for the GPR data that higher reflections are denoted by yellow and red, while weaker reflections are blue.

The GPR reflection profiles reveal several strong planar reflections within the area surveyed (Figure 11). Some anomalous reflections (red circles) may relate to bedrock deposits, subsurface boulders, or tree roots, and were mapped towards the southern extent of the study area from 50-140 cmbs (Figure 11a,b,d). Note the location of Square A (Figure 11a). The shell midden was visible (yellow dashed line) in the GPR reflection and extends to $\sim 60-80 \mathrm{cmbs}$. Figure $11 \mathrm{c}$ shows the same metal fragment described previously, visible as a strong and long hyperbola reflection (green circle). Below the shell midden and towards the southern extent of the survey area (where the shell midden starts to drop off), there is another subsurface layer denoted by a strong planar reflection (cyan line) around $200 \mathrm{cmbs}$. It is unknown what this feature may be but appears to be an old buried surface such as a sand ridge or dune that dips down towards the southern extent of the study area in the direction of the water (Figure 11c,d).

\section{Magnetic Susceptibility Analysis}

Magnetic susceptibility analysis reveals a strong correlation with stratigraphic units in the sedimentary sequence (Figure 12, see also Appendix C). The samples are weakly magnetic in the basal unit of SU6 and the lower section of SU5, with $\chi_{\mathrm{fd}}$ (\%) measurements of $\sim 16 \%$, but erroneous values in the lowest deposits were reported as sediments were too weakly magnetic to measure frequency dependence of susceptibility.
The $\chi_{\mathrm{fd}}(\%)$ for all samples in SU1, SU2, SU3, SU4, and the upper section of SU5 range between approximately $4 \%$ and $15 \%$, indicating a mix of magnetic grain sizes. Increases in both $\chi$ and $\chi_{\mathrm{fd}}(\%)$ occur in the upper section of SU5, which corresponds with documented increases in stone artefacts, macro-charcoal, and organics (Figure 12). Susceptibility values are highest in SU1, SU2, and SU3, and this is consistent with an increase in stone artefacts, macro-charcoal, organics, mollusc, and bone.

Increases in both $\chi$ and $\chi \mathrm{fd}(\%)$ occur in the top sections of SU5, SU3, and SU2. However, in the lowest section of SU5 (below $\sim 80 \mathrm{~cm}$ ) an increase in $\chi \mathrm{fd}(\%)$ and decrease in $\chi$ occurs, with a similar trend observed for SU4. Instances where an increase in both $\chi$ and $\chi \mathrm{fd}(\%)$ was documented tend to be associated with the interfaces between SU1 and SU2, SU2 and SU3, and SU4 and SU5, which indicates change in the fine-grained component of magnetic grains at these successive depths. These changes may represent developed surfaces and/or anthropogenic inputs such as burning. The inverse change of high $\chi \mathrm{fd}(\%)$ and $\chi$ values in SU4 are possible derivatives of sediment changes (i.e. increases in sands and silts). This also applies to the lower section of SU5 and SU6, as these basal sediments contain no cultural materials and are predominantly sand, with lower relative percentages of silt and clay (Figure 12). 

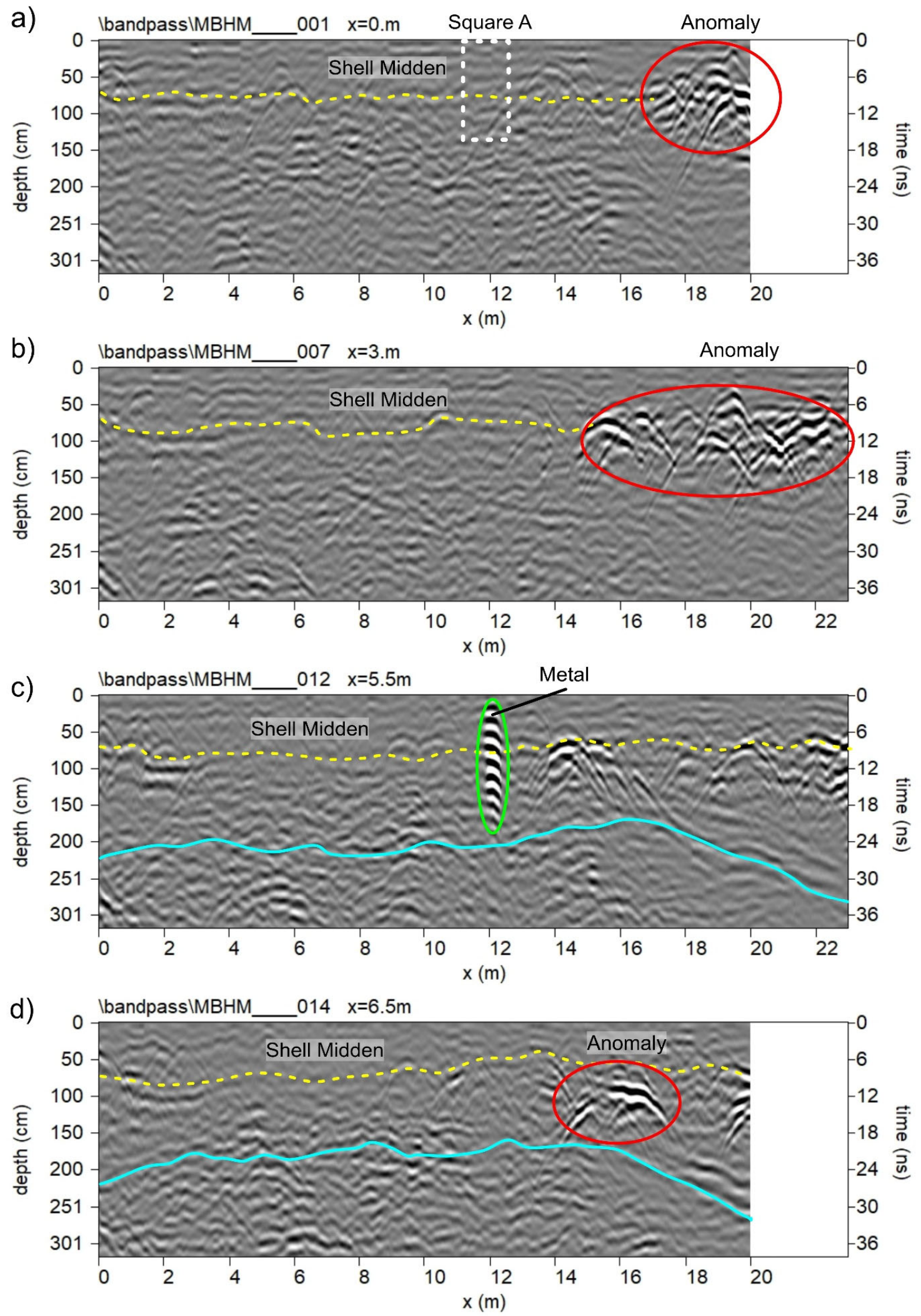

Figure 11. Reflection profiles (a) Profile 001, (b) Profile 007, (c) Profile 012, (d) Profile 014 showing the vertical distribution of the shell midden and the location of Site 3 Mangrove Beach Headland Midden, Square A. 


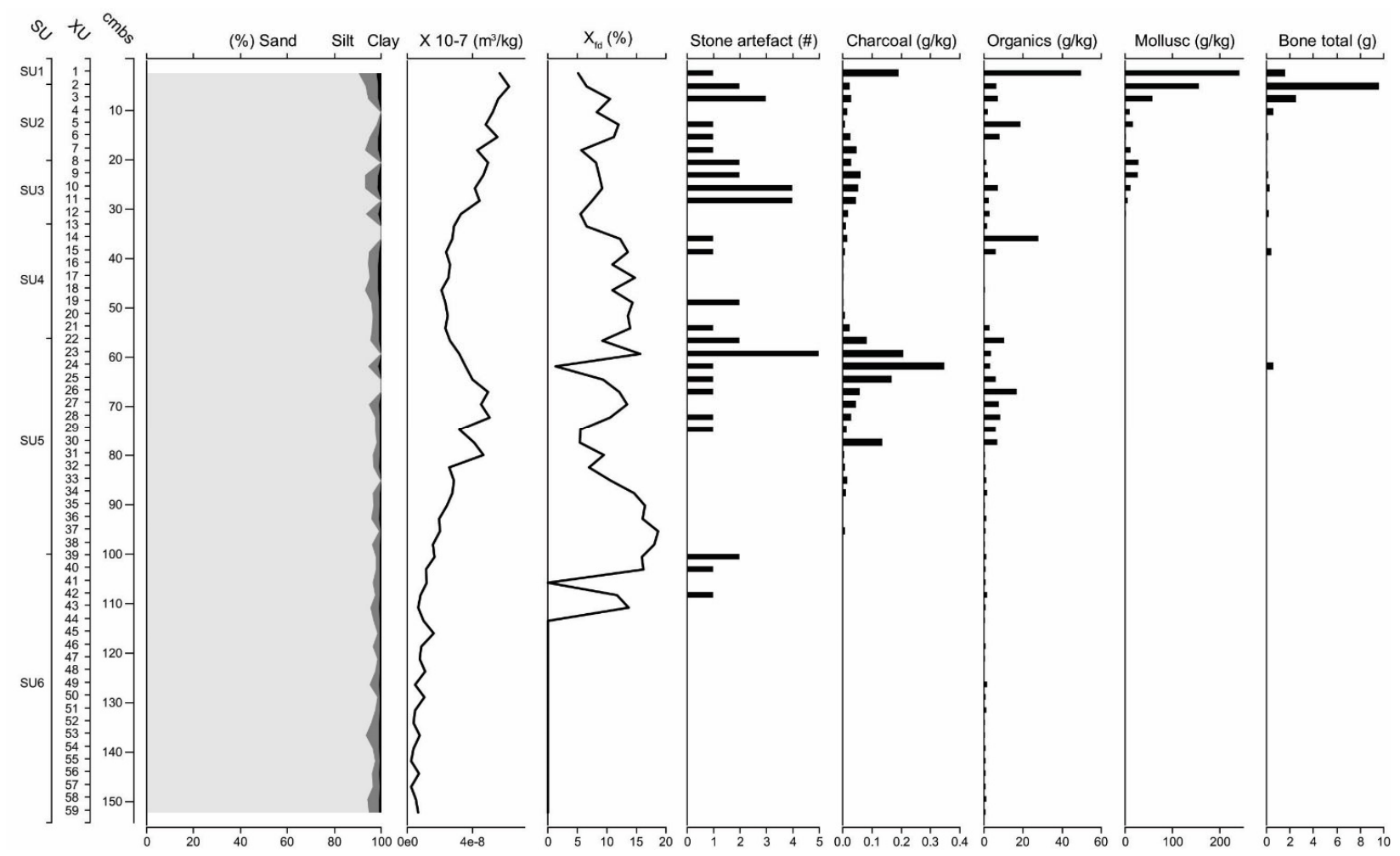

Figure 12. Changes in soil texture, low-field magnetic susceptibility $(\chi)$, frequency dependence of susceptibility $\chi_{\mathrm{fd}}(\%)$, and concentrations of stone artefacts, macro-charcoal, organics, mollusc, and bone with depth for Site 3 Mangrove Beach Headland Midden, Square A.

\section{Pollen and Micro-Charcoal Results}

Pollen-spore recovery decreased sharply with depth. Good grain preservation is limited to the upper seven XUs, corresponding to $1500-500$ cal BP. Micro-charcoal particles did not appear to deteriorate with depth and a record was obtained for the entire sequence. Palynological results are presented in Figure 13 and micro-charcoal in Figure 14. See Appendix D for pollen percentage and micro-charcoal concentration values.

Twenty-eight pollen-spore types were identified representing a wide range of both localised and regional island taxa, divided into trees, grasses and herbs, pteridophytes (ferns), aquatic plants, and mangroves.

Over half the sequence is dominated by grasses; high Poaceae values (64-73\% of the pollen sum) occur from XU7 and peak in XU4. Significant grass cover coincided with low tree-shrub abundance (majority values $<20 \%$, XUs $3-7$ ) suggestive of an open woodland surrounding the site from at least 1500 cal BP until 750 cal BP. This open woodland included mixed tree composition; Eucalyptus and Melaleuca presence was near matched by taxa such as Casuarinaceae and Callitris, with more sporadic Araucariaceae, Pandanus, and Arecaceae. Grassy ground cover existed to the exclusion of most herbs, however greater occurrence and diversity of ferns and sedges (Cyperaceae) indicate relatively moist undergrowth conditions 1500-750 cal BP. Available moisture at this time is further supported by the record of Pandanus, Leptospermum, and Arecaceae.

From 750 cal BP (XU3), and notably from 500 cal BP (XU2), grasses declined $(<20 \%)$. Tree abundance increased (to $60 \%$ ) and site woodlands thickened. Melaleuca and
Eucalyptus expanded to dominate the canopy, and with the loss of grasses, other herbs became more common. Herbs such as Asteraceae are dry-adapted (Moore 2005), with the onset of drier and potentially patchy undergrowth conditions further suggested by declines in all fern types and Cyperaceae up to the present day. The mixed nature woody composition also appears to have reduced with proportionally less secondary tree-shrub taxa.

Mangrove taxa do not reveal local palaeoecology but reflect longer-distance pollen transported into the site. Low values of Rhizophora, Avicennia marina, and Ceriops/Brugueria demonstrate the presence of an upper- and lower-tidal mangrove community within the broad vicinity, but not widespread growth, consistent with Proske and Haberle's (2012) findings of mangrove contraction at Watson's Bay, and possible progradation of shorelines within the past 2000 years.

Increased micro-charcoal deposition, incorporating progressively greater but fluctuating fire peaks, begins within the phase 4000-3750 cal BP (XU40), during 3750-3500 cal BP (XU35) and again through the early stages of 3500-3250 cal BP (from XU30). Micro-charcoal is most prominent between XU27 and XU22, corresponding to greatest burning through time centred on 3380 cal BP. By $3000-2750$ cal BP (XU14) the micro-charcoal particles decrease to a near minimum before values rise slightly $1750-1500$ cal BP (XUs 8-10). Burning at low levels continues through to the present day (reduced fires are reflected in the record of fire sensitive taxon Callitris, see Figure 13). Latest Holocene microcharcoal is comparable to trends recorded Mid-Holocene prior to XU40 (>4000 cal BP). Concentrations of microcharcoal notably decline $>4500$ cal BP (below XU51). 


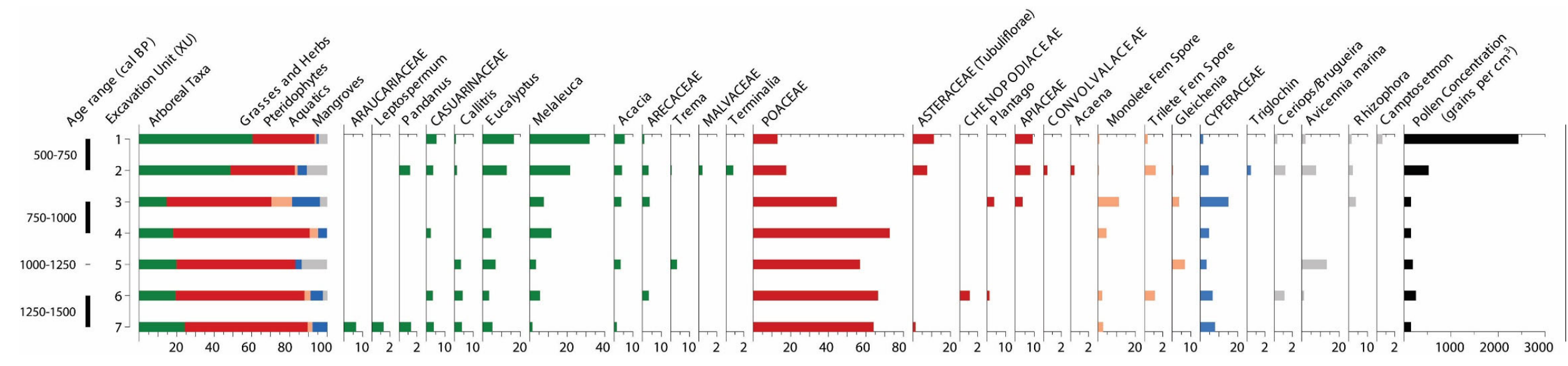

Figure 13. Site 3 Mangrove Beach Headland Midden, Square A, percentage pollen diagram plotted against XU and periodised 250-year time intervals developed using radiocarbon age determinations. All percentages derived from total pollen sum including spores. 


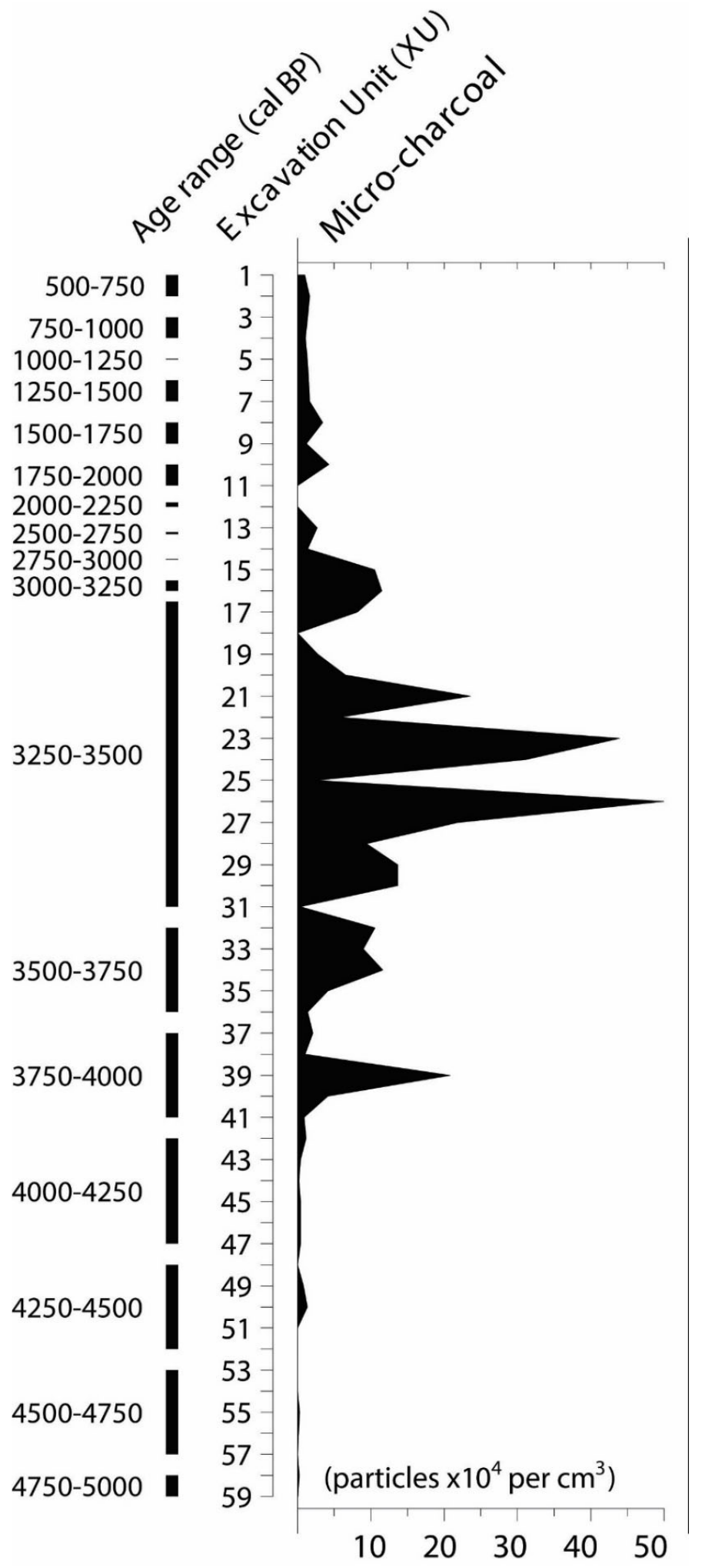

Figure 14. Site 3 Mangrove Beach Headland Midden, Square A, micro-charcoal (concentration) assemblage presented per XU and periodised 250-year time intervals developed using radiocarbon age determinations. Micro-charcoal has been defined as black angular fragments $>5 \mu \mathrm{m}$. 


\section{Invertebrate Remains}

A total of 11,127 mollusc shell fragments, weighing 20.1 $\mathrm{kg}$, were recovered from the site (see Table 3 and Appendix E). The molluscan assemblage was well preserved, with $<1.0 \%$ of the sample affected by burning and corrosion (see Hammond 2014, for a description of the considered taphonomic variables and methods for identifying these agents). Breakage patterns and/or instances of deliberate impact were recorded. For $C$. luhuanus specimens, $27.6 \%(n=477)$ of shell fragments had consistent breakage to the dorsal surface and $18.0 \%$ ( $n$ $=311$ ) to the ventral surface. Similar fragmentation patterns were observed for Lambis sp., but with only 7.2\% $(n=7)$ of shell fragments with breakage to the dorsal surface and $1.0 \%(n=1)$ to the ventral surface. $C$. luhuanus and Lambis sp. were the only taxa with these observed breakage patterns, potentially indicating a consistent anthropogenic breakage pattern possibly associated with meat extraction, or similar taphonomic process operating on shell of a similar morphology (i.e. strombids). Overall, the shell fragmentation ratio was 3.92 (NISP:MNI, Faulkner 2010), which indicates that on average there were $\sim 4$ fragments per identified individual, suggesting a high proportion of diagnostic fragments and complete mollusc shells.

Mollusc shell was recovered from most XUs (1-24, $26,28-31,42,50)$ with none reported from XUs 25, 27, 32-41 and 51-59. There was consistent evidence of mollusc exploitation from $\sim 3500-500$ cal BP. The indeterminate mollusc fragments $(\mathrm{NISP}=5$, weight $=0.03$ g) recovered from XUs 42 and 50 were from the SU5/6 diffuse zone and SU6 respectively, and it is likely these either moved down the sediment profile or are natural inclusions. The identified assemblage comprised 26 taxonomic categories, eight to order/family, six to genus, and 12 to species, for a total MNI of 1356 (NISP = 5287). Gastropod taxa dominate the molluscan assemblage, accounting for $97.4 \%(\mathrm{MNI}=1321)$, dominated by Conomurex luhuanus (NISP $=1726, \mathrm{MNI}=1201,88.6 \%$ $\mathrm{MNI}$ ) and a smaller component of Rochia nilotica (NISP $=65, \mathrm{MNI}=46,3.4 \% \mathrm{MNI})$. Bivalve taxa $(2.1 \%, \mathrm{MNI}=$ $28)$ and cephalopod taxa $(0.1 \%, \mathrm{MNI}=2)$, were only minor components of the recovered assemblage. This was supported by measures of taxonomic heterogeneity, with low taxonomic richness and high dominance of a single taxon $\left(C\right.$. luhuanus) reported (NTAXA $=15, H^{\prime}=0.435$, $\mathrm{E}=0.161,1-D=0.161$, Fisher's $\alpha=2.363$ ). Gross aggregated habitat assignments were established to facilitate broad categorisation of targeted zones and foraging methods (Beesley et al. 1998; Carpenter and Niem 1998; Wright 2018:Table 4.1). Identified mollusc species indicate that foraging efforts predominantly targeted intertidal benches, shallow subtidal reef flats, subtidal sandy substrates, and reef slopes (Table 3 ).

$C$. luhuanus was consistently the most commonly targeted species through time at the site, and $R$. nilotica the second most exploited during the majority of site occupation (Appendix E). Results indicate that a similar range of species were targeted, with no substantial shifts in their relative abundance through time. Morphometric analysis of these key molluscan species was undertaken and these results have previously been published (see Ulm et al. 2019). Lip thickness of $C$. luhuanus $(n=224)$ and base diameter of $R$. nilotica $(n=38)$ were measured to determine size-at-age habitat preferences and to facilitate high-resolution reconstructions of changes in foraging practices and targeted zones through time. Most specimens with measurable features occurred between $\sim 2000$ and $500 \mathrm{cal}$ BP, with adolescent $C$. luhuanus and adult $R$. nilotica dominating the assemblage. The dominance overall of adolescent $C$. luhuanus at the site indicates foraging efforts were particularly focused on subtidal sandy substrates and rock and rubble substrates of the intertidal reef flat.

A small pilot study was conducted to compare maximum shell length of $T$. maxima specimens from the archaeological deposit (surface transect and Square A assemblage) and a closely associated modern reef population to provide a gross comparison of population age-structure of this species through time (see Appendix F). Results indicate that $86.9 \%(n=73)$ of the archaeological population were juveniles $(\sim 1750-500 \mathrm{cal}$ BP) and $13.1 \%$ adults $(n=11)$, in comparison to the modern reef population, with $47.8 \%(n=55)$ juveniles and $52.2 \%$ adults $(n=60)$. Overall, sample size was insufficient to draw robust conclusions regarding population age-structure of this species through time, particularly given few measurable valves were recovered during excavation, and only limited sampling of the modern reef population was conducted. However, results provide some support for the conclusion that foraging efforts preferentially targeted juvenile $T$. maxima individuals situated along the shallow reef flat adjacent to the site.

\section{Vertebrate Remains}

\section{Fish}

A total of 238 fish bones, weighing $9.26 \mathrm{~g}$, was recovered from the Site 3 MBHM (Table 4 and Appendix G). Fish bone was recovered from XUs 1-16, 22, 24-25, and 2728 , with none reported from XUs 17-21, 23, 26, and 2959. The assemblage was highly fragmented, with the majority of fish bones recovered less than $10 \mathrm{~mm}$ in length or $\sim 0.04 \mathrm{~g}$ per element. Accordingly a low portion $13.0 \%$ overall - were identified to taxon. Fine mesh sieving directly facilitated the recovery of these highly fragmented fish remains from the site. Of the 31 fish bones identified to taxon and three to element only, $\sim 9.6 \%(n=$ 3 ) were burnt, with no indication that any bones were altered by digestive processes (see Butler and Schroeder 1998). At the site level, teeth were the most commonly identified element $(77.4 \%)$, followed by dentaries/premaxillae (16.1\%), and then vertebrae (6.5\%). Only $\sim 1.0 \%$ of the total fish bone assemblage recovered $(n=3)$ could be identified to only element but not taxon.

A continuous presence of fish bone through time is evident ( 3500-500 cal BP) though, compared to molluscs, the relative abundance of fish at the site is low. Overall, this small assemblage is dominated by parrotfish (Scaridae), a family that occupy diverse zones from the inshore reef flat to the deeper, oceanward portions of the reef, including the lagoon, shelves, and channels (Froese and Pauly 2018; Myers 1999; Randall et al. 1997). Parrotfish frequently inhabit coral reef and other hard bottom substrates as well as areas of sand and seagrass, and shallow water over reefs (Froese and Pauly 2018; 
Table 3. Mollusc remains recovered from Site 3 Mangrove Beach Headland Midden, Square A. Note that MNI values were calculated according to periodised 250 -year time intervals developed using radiocarbon age determinations, and only the site totals are presented. See Appendix E for detailed quantification data.

\begin{tabular}{|c|c|c|c|c|c|c|c|}
\hline Taxon & Common Name & Habitat & NISP & $\%$ NISP & MNI & $\% \mathrm{MNI}$ & Weight (g) \\
\hline \multicolumn{8}{|l|}{ Marine Mollusca } \\
\hline Indeterminate Mollusca & & & 4631 & & & & 179.92 \\
\hline \multicolumn{8}{|l|}{ Bivalvia } \\
\hline Indeterminate Bivalvia & & & 30 & & & & 18.86 \\
\hline \multicolumn{8}{|l|}{ Cardiidae } \\
\hline Hippopus hippopus & $\begin{array}{l}\text { Horse's hoof } \\
\text { clam }\end{array}$ & Reef flat & 1 & 0.02 & 1 & 0.07 & 0.26 \\
\hline Tridacna crocea & Boring clam & Reef flat & 4 & 0.08 & 4 & 0.29 & 558.72 \\
\hline Tridacna gigas & Giant clam & Reef flat & 1 & 0.02 & 1 & 0.07 & 12.37 \\
\hline Tridacna maxima & $\begin{array}{l}\text { Rugose giant } \\
\text { clam }\end{array}$ & Reef flat & 24 & 0.45 & 11 & 0.81 & 2405.43 \\
\hline Tridacna spp. & & Reef flat & 173 & 3.27 & 5 & 0.37 & 871.09 \\
\hline Ostreidae & Oyster & & 19 & 0.36 & 4 & 0.29 & 7.49 \\
\hline \multicolumn{8}{|l|}{ Veneridae } \\
\hline Periglypta puerpera & Youthful venus & $\begin{array}{l}\text { Intertidal - } \\
\text { sand/mud }\end{array}$ & 3 & 0.06 & 2 & 0.15 & 2.68 \\
\hline \multicolumn{8}{|l|}{ Cephalopoda } \\
\hline \multicolumn{8}{|l|}{ Nautilidae } \\
\hline Nautilus sp. & Nautilus & Reef slope & 1 & 0.02 & 1 & 0.07 & 16.46 \\
\hline Sepiida & Cuttlefish & Reef slope & 1 & 0.02 & 1 & 0.07 & 2.41 \\
\hline \multicolumn{8}{|l|}{ Gastropoda } \\
\hline Indeterminate Gastropoda & & & 1179 & & & & 194.79 \\
\hline Conidae & Cone snails & & 1 & 0.02 & 1 & 0.07 & 7.23 \\
\hline Conus sp. & & Varied & 1 & 0.02 & 1 & 0.07 & 63.94 \\
\hline Muricidae & Murex snails & & 1 & 0.02 & 1 & 0.07 & 0.56 \\
\hline Thais sp. & Dog winkle & Intertidal-hard & 2 & 0.04 & 1 & 0.07 & 2.39 \\
\hline Neritidae & Nerites & & & & & & \\
\hline Nerita costata & & Intertidal-hard & 1 & 0.02 & 1 & 0.07 & 0.76 \\
\hline Nerita polita & & Intertidal-hard & 8 & 0.15 & 5 & 0.37 & 8.91 \\
\hline Nerita spp. & & Varied & 9 & 0.17 & 4 & 0.29 & 4.30 \\
\hline Strombidae & True conchs & & 119 & 2.25 & 14 & 1.03 & 57.03 \\
\hline Conomurex luhuanus & Strawberry conch & Reef flat & 1726 & 32.65 & 1201 & 88.57 & 7837.13 \\
\hline Lambis lambis & Spider conch & Reef flat & 26 & 0.49 & 13 & 0.96 & 728.86 \\
\hline Lambis sp. & & Reef flat & 71 & 1.34 & 13 & 0.96 & 410.56 \\
\hline Tegulidae & Top shells & & 2946 & 55.72 & 13 & 0.96 & 767.91 \\
\hline Rochia nilotica & & Reef flat & 65 & 1.23 & 46 & 3.39 & 5931.05 \\
\hline \multicolumn{8}{|l|}{ Trochidae } \\
\hline Monodonta labio & Toothed top shell & Intertidal-hard & 14 & 0.26 & 3 & 0.22 & 7.04 \\
\hline Vermetidae & Worm snail & Reef flat & 62 & 1.17 & 4 & 0.29 & 1.52 \\
\hline \multicolumn{8}{|l|}{ Polyplacophora } \\
\hline \multicolumn{8}{|l|}{ Chitonidae } \\
\hline Acanthopleura gemmata & Jewelled chiton & Intertidal-hard & 1 & 0.02 & 1 & 0.07 & 0.41 \\
\hline \multicolumn{8}{|l|}{ Terrestrial Mollusca } \\
\hline \multicolumn{8}{|l|}{ Gastropoda } \\
\hline Rhytididae & Land snail & Terrestrial & 7 & 0.13 & 4 & 0.29 & 0.43 \\
\hline Total identified & & & 5287 & & 1356 & & \\
\hline Total Mollusca & & & 11127 & & & & \\
\hline Total weight (g) & & & 20100.51 & & & & \\
\hline$\%$ identified & & & 47.52 & & & & \\
\hline
\end{tabular}


Table 4. Fish remains recovered from Site 3 Mangrove Beach Headland Midden, Square A. Note that MNI values were calculated according to periodised 250-year time intervals developed using radiocarbon age determinations, and only the site totals are presented. See Appendix $\mathbf{G}$ for detailed quantification data. $\mathbf{P}=$ piscivore; $\mathbf{H}=$ herbivore.

\begin{tabular}{|c|l|l|l|l|l|l|l|}
\hline \multicolumn{1}{|c|}{ Taxon } & \multicolumn{1}{|c|}{ Common Name } & $\begin{array}{c}\text { Feeding } \\
\text { Behaviour }\end{array}$ & NISP & \%NISP & MNI & \%MNI & $\begin{array}{c}\text { Weight } \\
\text { (g) }\end{array}$ \\
\hline Chondrichthyes & & & & & & & \\
\hline Elasmobranchii & Sharks, skates, rays & P & 2 & 6.45 & 2 & 13.33 & 0.02 \\
\hline Actinopterygii & & & & & & & \\
\hline Indeterminate (element only) & & & 3 & & & & 0.19 \\
\hline Scaridae & parrotfish & H & 27 & 87.10 & 11 & 73.33 & 1.68 \\
\hline Bolbometopon muricatum & green humphead parrotfish & H & 2 & 6.45 & 2 & 13.33 & 0.12 \\
\hline $\begin{array}{l}\text { Total identified (excl. } \\
\text { indeterminate fish to element) }\end{array}$ & & & $\mathbf{3 1}$ & & $\mathbf{1 5}$ & & \\
\hline Total bones & & & $\mathbf{2 3 8}$ & & & & \\
\hline Total weight (g) & & & $\mathbf{9 . 2 6}$ & & & & \\
\hline \% identified & & & $\mathbf{1 3 . 0 3}$ & & & & \\
\hline
\end{tabular}

Randall et al. 1997). Parrotfish can be found in small to large aggregations, which are often mixed-species. These schools can move across large areas of the reef in a day as they graze on benthic algae and coral (Marshall 1965; Randall et al. 1997). Here we report the first archaeological record of green humphead parrotfish (Bolbometopon muricatum) exploitation from a Queensland coastal archaeological site (see Lambrides et al. 2019). B. muricatum are the largest species of parrotfish growing to $130 \mathrm{~cm}$ (commonly $70 \mathrm{~cm}$ ) in length, feeding in small aggregations on benthic algae and coral during the day, and sleeping at night in groups in caves or other sheltered areas. This group sheltering behaviour makes this species vulnerable to spearfishing (Froese and Pauly 2018; Myers 1999; Randall et al. 1997). While juveniles are frequently found in lagoons, adults tend to be associated with seaward reefs, particularly the outer-shelf reef crest and flat, such as surveyed Yonge, Day, and Hicks Reefs, approximately $20 \mathrm{~km}$ from Lizard Island (Froese and Pauly 2018; Hoey and Bellwood 2008). However, B. muricatum still does occur on the reefs in the vicinity of Lizard Island. Often described as the major coral predator on reefs, this species is a nonselective feeder that promotes coral diversity and can increase the resilience of corals to storm and wave dislodgement (Bellwood et al. 2003; Hoey and Bellwood 2008). In the Great Barrier Reef, green humphead parrotfish are the only species to perform this key role, and fundamentally contribute to long-term reef health in the region (Hoey and Bellwood 2008). There was also evidence for the exploitation of sharks, skates or rays (Elasmobranchii), however, this taxonomic grouping is too general to allow for habitat assignment.

Broadly, there is the potential for a wide range of habitats from the reef flat through to the deeper bank/shelf to have been exploited across millennia of site occupation, especially given the diverse reef zones parrotfish traverse daily and the variability in habitat preferences between species. It is probable that parrotfish would have been exploited using netting and spearfishing, however, no material culture was recovered to provide direct evidence of utilised capture techniques.

\section{Turtle}

Turtle remains (Cheloniidae) were recovered from XU1 $(\mathrm{NISP}=1$, weight $=0.47 \mathrm{~g})$ and $\mathrm{XU} 2(\mathrm{NISP}=28$, weight $=$ $6.24 \mathrm{~g}$ ), all fragments of carapace or plastron representing a minimum number of one adult or juvenile individual. There were no indications of burning or modification, and all remains were associated with the most recent phase of site occupation ( $750-500$ cal BP). Three species of turtle have been reported at Lizard Island, the logger-head turtle (Carretta caretta), green turtle (Chelonia mydas), and hawksbill turtle (Eretmochelys imbricata) (see the Lizard Island Field Guide: lifg.australianmuseum.net.au). Small green turtles (carapace length $40-50 \mathrm{~cm}$ ) are the most common species at Lizard Island and are frequently observed feeding on seagrass beds in proximity to Site $3 \mathrm{MBHM}$, but with infrequent reports of nesting (Goatley et al. 2012).

\section{Material Culture}

\section{Stone Artefacts}

Flaked stone artefacts $(n=333$, weight $=198.32 \mathrm{~g})$ were recovered from XUs 1-30, 33, 39-40, 42, and 45, with none reported from XUs 31-32, 34-38, 41, 43-44 and 46-59 (see Appendix H). There was an initial peak in stone artefact discard between XUs 21 and $25(n=71,3500-3250$ cal BP), with the highest density of stone artefacts from XUs 1-12 (n $=213,2250-500 \mathrm{cal} \mathrm{BP}$ ), and low numbers occurring in the remainder of Square A $(n=49)$ (Figure 12). Seven fracture types were recovered from Square A, flakes $(n=294,88.3 \%)$, flaked pieces $(n=21,6.3 \%)$, bipolar flakes $(n=8,2.4 \%)$, bipolar cores $(n=5,1.5 \%)$, cores $(n=2,0.6 \%)$, ground edge fragments $(n=2,0.6 \%)$, and a microblade $(n=1,0.3 \%)$. No indication of retouch of flaked stone artefacts was recorded at the site. The dominant raw materials throughout the deposit, accounting for $99.1 \%$ of flaked stone artefacts, were quartz ( $n$ $=312)$ and crystal quartz $(n=18)$, with the remainder manufactured from granite $(n=1)$, sedimentary $(n=1)$, and volcanic sources $(n=1)$. Quartz outcrops have been documented across Lizard Island and a local source for these Square A quartz artefacts is probable (Lentfer et al. 2013; Mills 1992, 1995a, 1995b). One ground edge-fragment, 
potentially from an axe, was made from volcanic stone, and is the only artefact that could have been produced from nonlocally sourced raw material. This artefact may indicate movement of raw materials from the adjacent mainland, but at this stage, the source of this raw material is inconclusive.

The dominant recovered fracture type was flakes, and on average each complete flake $(n=132)$ weighed $0.7 \mathrm{~g}$, had a mean length of $9.4 \mathrm{~mm}$, width of $8.4 \mathrm{~mm}$, elongation (length/width) of 1.2, and platform angle of $\sim 65^{\circ}$, suggesting overall the flakes were very squat, with slightly contracting margins (after O'Connor et al. 2014). No notable differences in flake shape were observed between the initial peak in flake discard ( $n=26$, XUs 21-25, 3500-3250 cal BP, but no complete flakes were recovered from XU21) and the period of highest flake discard ( $n=91$, XUs $1-12,2250-500$ cal BP), with a low number of complete flakes $(n=15)$ recovered from the remainder of Square A (XUs 13-16, 19, 28-29, 39-40, 42, 45). On average flakes were consistently small, squat, and with slightly contracting margins as observed initially at $3500-3250$ cal BP (weight $=0.7 \mathrm{~g}$, length $=11.3 \mathrm{~mm}$, width $=9.6 \mathrm{~mm}$, elongation $=1.3$, platform angle $=\sim 67^{\circ}$ ) and through to the most recent phase of site occupation 2250-500 cal $\mathrm{BP}$ (weight $=0.7 \mathrm{~g}$, length $=9.1 \mathrm{~mm}$, width $=8.2 \mathrm{~mm}$, elongation $=1.2$, platform angle $=\sim 64^{\circ}$ ).

The earliest evidence for bipolar reduction at the site was from XU23 ( $n=1,3500-3250$ cal BP), but with the highest density of bipolar flakes $(n=8)$ and cores $(n=4)$ recovered from XUs $1-14$ (3000-500 cal BP). Overall, only $3.9 \%$ of the flaked stone artefacts were reduced using bipolar techniques. On average each complete bipolar flake weighed $1.1 \mathrm{~g}$, had a mean length of $16.0 \mathrm{~mm}$, width of $9.7 \mathrm{~mm}$, elongation of 1.7 , and platform angle of $\sim 72^{\circ}$. Relatively, the bipolar flakes were larger and more elongate, but would still be considered squat with slightly contracting margins.

\section{Ochre}

A low density of red ochre was reported, with six small fragments (XU23, weight $=3.10 \mathrm{~g}$ ) dating to $3500-3250 \mathrm{cal}$ $\mathrm{BP}$ recovered from the site (Appendix B). A ground facet was not explicitly identified on any of the recovered ochre fragments (after McNiven et al. 2014), and as such their attribution as cultural is tentative.

\section{Discussion}

Palaeoenvironmental analyses on Lizard Island undertaken on the southern (Site $3 \mathrm{MBHM}$ and Site 17 FBM) and eastern (Watson's Bay) coasts record Late Holocene drying conditions and a rise in micro-charcoal concentration and fire frequency between 4000 and 3000 cal BP. This pattern suggests the occurrence of regional burning events spanning the Mid-to-Late Holocene that correspond with the earliest evidence for Aboriginal occupation of Lizard Island (Lentfer et al. 2013; Proske and Haberle 2012). Late Holocene vegetation succession following peaks in burning differs across Lizard Island, which indicates that although island burning was common, individual fire characteristics varied according to location, and ultimately influenced island vegetation communities differently. Lentfer et al. (2013) and Proske and Haberle (2012), for example, report trajectories of increasingly open vegetation communities following high frequencies of charcoal. At Site $3 \mathrm{MBHM}$, vegetation structure became more wooded through time. Lentfer et al. (2013) indicate that after frequent fire, there is initial recovery of myrtaceous plants and Acacia from at least $1725 \mathrm{cal}$ BP, followed by a rise associated with a more disturbed and open environment during the recent past. At Watson's Bay, increasingly dominant grassland and sclerophyll vegetation incorporated more abundant Cyclosorus ferns, which suggested enhanced vegetation disturbance from $\sim 1500$ cal BP onwards (Proske and Haberle 2012). At Site 3 MBHM, there is also evidence for a rise in Eucalyptus, Melaleuca (Myrtacaeae taxa), and Acacia following the period of maximum micro-charcoal, but the same transition to higher grasses, most recently, as recorded for Site 17 FBM and Watson's Bay, is absent. Furthermore, ferns at Site 3 MBHM remain low between 750 and 500 cal BP rather than becoming more abundant as documented elsewhere on Lizard Island.

This discrepancy between the other reported palaeoenvironmental records from Lizard Island and Site 3 MBHM may indicate that sediments are missing from the surface of this site. This trend is further supported by the environmental disturbance reported at Site 17 FBM and Watson's Bay from 1500 years ago (Lentfer et al. 2013; Proske and Haberle 2012). An increase in the visible surface area of the study site has been recorded over the last several decades $\left(\sim 75-100 \mathrm{~m}^{2}\right.$ to $2250 \mathrm{~m}^{2}$ ) (cf. Mills 1992; Specht 1978), and potentially indicates cyclonic activity and erosional processes may have successively removed the most recently accumulated deposits. However, given molluscs across the surface of the site were uniformly dated to $\sim 500 \mathrm{cal}$ BP, this may suggest that while sediment is potentially missing, a reduction or cessation of site use either occurred around this time, or cyclonic activity may have uniformly removed evidence for the past 500 years of cultural discard at the site.

Proske and Haberle (2012) also recorded increased fire frequencies from 1500 years ago, but this fire regime and pattern of site change is not seen at Site 3 MBHM. This trend further emphasises that individual fire characteristics varied according to location, and potentially the differential influences of natural fires and human activities across the landscape. At Watson's Bay, there was no evidence for the loss of dominant vegetation communities during the Late Holocene, but local extinction of Sonneratia (a component of mangrove forests) and Ilex (a component of rainforest patches) is followed by increases in micro-charcoal and may indicate increased disturbance over the past 2000 years (Proske and Haberle 2012). This also corresponds with an increase in the discard of cultural material at both Site 3 MBHM and Site 17 FBM. Specifically, at Site 3 MBHM magnetic susceptibility values are highest in the top section of the deposit down to $\sim 30 \mathrm{~cm}$ below surface, and this is consistent with an increase in stone artefacts, macro-charcoal, organics, mollusc, and bone from $\sim 2000 \mathrm{cal} \mathrm{BP}$.

The GPR survey at Site 3 MBHM indicated the subsurface midden across the site extended 60 to $80 \mathrm{~cm}$ below the surface, consistent with the highest concentration of recovered mollusc remains from Square A. Subsistence remains at the site are dominated by molluscs, with evidence of mollusc exploitation between $\sim 3500$ and 500 cal BP demonstrating that a similar range of species was targeted through time, but most particularly $C$. luhuanus and $R$. nilotica. These taxa indicate foraging efforts were likely targeted towards intertidal benches, shallow subtidal reef flats, subtidal sandy substrates, and reef slopes. An increase in the discard of molluses remains between $\sim 2000 \mathrm{cal} \mathrm{BP}$ and 
500 cal BP was documented, but presently there is no indication that anthropogenic and/or environmental factors altered the availability or population structure of these key exploited species (Ulm et al. 2019). Specifically, people were able to preferentially target adolescent and adult $C$. luhuanus and $R$. nilotica individuals, and juvenile T. maxima individuals (based on a small pilot study), throughout the occupation of the site. Fish bone abundances are low when compared to the representation of mollusc remains at Site 3 MBHM but were similarly exploited from 3500 to $500 \mathrm{cal} \mathrm{BP}$, suggesting that fish were potentially a minor, but consistent component of subsistence regimes. Here we have reported the first evidence for the exploitation of green humphead parrotfish (B. muricatum) at a Great Barrier Reef archaeological site at $\sim 2000-1750$ cal BP. This species has recently suffered rapid population decline (Hoey and Bellwood 2008), and these deep time records help to clarify historic biogeographic ranges for this keystone species. There was limited evidence for the exploitation of turtle, with all recovered remains associated with the most recent phase of site occupation $(\sim 750-500$ cal BP). Turtle may be underrepresented in sites owing to butchering and consumption on nearby beaches (Anderson and Robins 1988).

In terms of material culture, there was a dominance of quartz artefacts recovered from Site $3 \mathrm{MBHM}$, likely sourced locally given the well-documented quartz outcrops across Lizard Island. One ground edge-fragment, potentially from an axe, was made from volcanic stone, and may indicate the movement of raw materials from the adjacent mainland or elsewhere, but its source is not conclusive at this stage. Two peaks in stone artefact discard (3500-3250 and 2250-500 cal $\mathrm{BP}$ ) were recorded, with evidence for increased use of bipolar techniques from $\sim 2250$ cal $\mathrm{BP}$, a technique useful for fracturing small quartz cores and minimising flake fragmentation (e.g. Hiscock 1996; Tallavaara et al. 2010). There was no evidence that the quartz artefacts had been retouched, potentially due to the local availability of this resource; this may have minimised the need to extend the use life of the material through retouching. Finally, the use of red ochre has been documented at multiple art sites on Lizard Island (Arnold 2020; Mills 1992), but here we report the first evidence of the recovery of ochre from a stratified deposit.

Lizard Island archaeological sites are dominated by small quartz artefacts and faunal remains (e.g. mollusc, fish, and turtle). An increase in the discard of quartz artefacts from $\sim 2250$ cal BP at Site 3 MBHM is largely consistent with trends documented at nearby Site 17 FBM, where the highest discard rates were reported from $\sim 2500$ cal BP from Trench 1 (Mills 1992) and $\sim 1750$ cal BP from the more recently excavated Trench 2 (Lentfer et al. 2013). Regional subsistence trends suggest a focus on marine resources, particularly molluscs, with limited evidence for the exploitation of vertebrate, and particularly terrestrial, fauna. Only a small quantity of bird and lizard remains were reported from Site 17 FBM (Mills 1992). A consistent increase in the discard of mollusc remains from $\sim 2000$ cal BP was reported at Site $3 \mathrm{MBHM}$ and Site $17 \mathrm{FBM}$, with a similar range of species targeted between sites, including the preferential exploitation of $C$. luhuanus and R. nilotica individuals, and no significant alterations in the range of species exploited through time. A preference for small inshore reef taxa (e.g. scarids and labrids) and small, potentially juvenile, elasmobranchs is evident at Site 3 MBHM ( 3500-500 cal
BP) and Site 17 FBM ( 2000-750 cal BP), but with low relative abundances reported at both sites (Lentfer et al. 2013; Mills 1992).

Interestingly, while only $6.7 \mathrm{~g}$ of turtle bone was recovered from Site $3 \mathrm{MBHM}$ and associated with the most recent phase of site occupation $(\sim 750-500$ cal BP), at Site 17 FBM a considerable amount of turtle bone (652.7 g) was excavated and dated to the past 2250 years (Mills 1992). Ethnographic records suggest that turtles were an important resource accessed when voyaging to Lizard Island (Mills 1995a), but the archaeological record seems to suggest variability in the discard of turtle remains between sites. Currently there is limited evidence for the exploitation of dugong on Lizard Island, with no dugong remains recovered from Site $3 \mathrm{MBHM}$, and a minor quantity $(20.8 \mathrm{~g})$ recovered from Site 17 FBM dating to $\sim 1500$ cal BP (Mills 1992). However, Mills (1992:Figure 21) also documented a small dugong bone mound on the surface of Site 17 FBM. The low relative abundance of dugong bone recovered archaeologically may indicate restricted availability (due to limited seagrass food resources), culturally restricted exploitation, or inconsistent transport of dugong remains to the sites. The absence of dugong remains at Site $3 \mathrm{MBHM}$ is consistent with the low relative quantity of turtle remains at the site when compared with Site 17 FBM. Of relevance here is McNiven and Feldman's (2003) discussion of Torres Strait hunting rituals and the use of dugong bones in ritual bone mounds, particularly the associated implications of differential discard of faunal remains between sites (see also McNiven and Wright 2008). Here, the relative absence and/or differential discard of dugong and turtle remains between sites on Lizard Island may relate to social and cultural distinctions in the treatment and discard of their remains across the landscape, though further clarification of this pattern is required.

Based on this available archaeological evidence, Lizard Island was first occupied at $\sim 4040$ cal BP, which post-dates island formation by at least 4000 years, but during the potentially sustained high-stand until $\sim 2300$ cal BP. Regionally, there is evidence for lower relative patterns of site use during the initial phases of occupation, and this initial occupation of Lizard Island corresponds to a welldocumented regional burning event (Proske and Haberle 2012). Yet, there are notable increases in the discard of cultural materials from $\sim 2250$ cal BP (Site 3 MBHM and Site 17 FBM), and at the time when sea-levels began falling to modern levels along the northeast Australia coastline (Lewis et al. 2013, 2015). Lentfer et al. (2013) argued the absence of molluscs remains, for instance, from the earliest phases of site occupation, may be an issue of preservation, particularly due to the recovery of stone artefacts throughout the sequence. However, the recovery of fish bone and some mollusc shell from sediments associated with the earliest phases of site occupation at both Site $3 \mathrm{MBHM}$ and Site 17 FBM, more likely indicates this documented increase in the relative abundance of cultural material is related to changes in site use and discard rates through time.

The available archaeological evidence also complements the ethnographic and ethnohistoric records for the use of Lizard Island. Specifically, the archaeological evidence supports periodic occupation of Lizard Island, likely shortterm and perhaps seasonally by people with connections to the mainland or elsewhere. Such short-term use is similar to 
patterns of island use documented for the Shoalwater Bay region of the central Great Barrier Reef (McNiven et al. 2014) and preliminary results from the northern extent of the region for the Flinders Islands (Wright 2018), but unlike reports for the Whitsunday and Keppel Islands (Barker 2004; Rowland 1996).

The ethnographic, ethnohistorical, and archaeological records provide insight into the motivations for voyaging to Lizard Island, including targeted resource acquisition (e.g. molluscs and turtles), and furthermore, the social and cultural significance of the region as a place for gathering and ceremony, including the documented stone arrangements and art sites (Arnold 2020; Fitzpatrick et al. 2018; Mills 1992). However, it is apparent that the currently available archaeological evidence from Lizard Island may provide the first example of a previously undocumented occupation pattern associated with the Great Barrier Reef islands during the Late Holocene. Specifically, the Lizard Island archaeological evidence hints that an occupation hiatus does not occur between 2000 and 1000 years ago (see also Lentfer et al. 2013; Mills 1992), in contrast with equivalent highresolution records available for other offshore islands along the length of the Great Barrier Reef (Barker 2004; Border 1999; McNiven et al. 2014; Rowland 1996; Wright 2018).

On Lizard Island, it appears that the frequency and/or length of visits increased during the past $\sim 2,000$ years of occupation, as documented by an increase in the discard of cultural material. We suggest the ongoing occupation of Lizard Island from 4040 cal BP could relate to several locally specific factors. Firstly, the social and cultural significance of Lizard Island as a place of ceremony and gathering, which is supported by well-documented stone arrangements, interpreted as material expressions of these socio-cultural practices (Fitzpatrick et al. 2018; see also Greer et al. 2015). Secondly, is the potential importance of the Lizard Island Group within the Coral Sea Cultural Interaction Sphere (McNiven et al. 2004). Fitzpatrick et al. (2018) have suggested that the Lizard Island stone arrangements do share attributes with those from Cape York Peninsula and Torres Strait Islands, and the recent pottery finds - from the lagoon excavations - also raise questions about cultural links with Melanesia (Lentfer et al. 2013; Tochilin et al. 2012). Furthermore, the increase in the discard of cultural material at Lizard Island archaeological sites ( 2250 cal BP) roughly corresponds to the onset of the Torres Strait Cultural Complex ( 2500 cal BP) (Barham 2000), which McNiven et al. (2006) link to demographic expansion and the immigration of pottery-making peoples from southern New Guinea to the eastern and western islands of Torres Strait. More detailed archaeological evidence is clearly required to explore the potential place of Lizard Island within the Coral Sea Cultural Interaction Sphere. However, here we demonstrate an ongoing record of Lizard Island occupation from initial settlement, which in combination with ethnographic records, documents both the socio-cultural significance of this region and its possible links (both direct and indirect) with peoples from Torres Strait and the southwest Pacific. Hence, this Lizard Island record provides a unique insight into an otherwise undocumented pattern of Late Holocene offshore island occupation on the Great Barrier Reef.

\section{Conclusion}

As new archaeological records of Great Barrier Reef offshore island occupation become available, an increasingly nuanced picture of the use of these islands by Aboriginal and Torres Strait Islander peoples during the Mid-to-Late Holocene is formed. These islands not only provided access to key resources, but were likely places of socio-cultural significance, and in the case of Lizard Island a place of ceremony and gathering. At Lizard Island we see an increase in island use from 2000 years ago, at a time when a hiatus or reduction in offshore island occupation has been documented for other Great Barrier Reef islands, but concurrent with the onset of the Torres Strait Cultural Complex and associated demographic expansion. This association potentially demonstrates the complex interplay between the environmental, economic, social, and cultural factors that influenced and shaped island occupation in this region. More comprehensive records of landscape use across the entire Lizard Island Group are still required. Available evidence is constrained to Lizard Island, and broader work is needed on nearby islands to generate a more nuanced perspective on the frequency and intensity of island use. Within the broader Great Barrier Reef region, it is plausible that this unique pattern of site occupation documented for Lizard Island relates to its place within the Coral Sea Cultural Interaction Sphere and its significance both locally and regionally within a vast, networked seascape. Yet, future work is required to evaluate these themes, and importantly, to generate a comprehensive framework from which to consider offshore island use in northeast Australia more broadly, but also the dynamic history of Lizard Island occupation.

\section{Acknowledgements}

We acknowledge the Dingaal Aboriginal community as partners in this research. This research was supported by the Australian Research Council Centre of Excellence for Australian Biodiversity and Heritage (project number CE170100015), the Scarp Archaeology Richard Brookdale Scholarship to SA, and an Australian Research Council Future Fellowship to SU (project number FT120100656). We extend a special thanks to: Dr Anne Hoggett and Dr Lyle Vail for hosting us at the Australian Museum's Lizard Island Research Station; Kara Rasmanis (then Monash University) for preparing Figure 9; Javier Leon (University of the Sunshine Coast) for advice on mapping data; Jim Specht (Australian Museum) for advice and kindly supplying photographs. Adriana Basiaco, Simon Coxe, Alison Fitzpatrick, Shoshanna Grounds, Robyn Jenkins, Helene Peck, Tammy Purssell, and Ioana Zaharia assisted with the excavation of the site. Fieldwork on Lizard Island was conducted under Queensland Government Department of Environment and Heritage Protection Permit Number WITK12835313. Figure 3 contains data provided by the State of Queensland [2017]. In consideration of the State permitting use of this data we acknowledge and agree that the State gives no warranty in relation to the data (including accuracy, reliability, completeness, currency or suitability) and accepts no liability (including without limitation, liability in negligence) for any loss, damage or costs (including consequential damage) relating to any use of the data. Data must not be used for direct marketing or be used in breach of the privacy laws. We thank the Editor, Mike Rowland, and three anonymous reviewers for their thoughtful comments on the manuscript. 


\section{References}

Aird, S. 2014 Assessing Mid-to-Late Holocene Predation of Conomurex luhuanus and Tectus niloticus at Lizard Island, Northeastern Australia. Unpublished BA (Hons) thesis, College of Arts, Society and Education, James Cook University, Cairns.

Alder, J. and R. Braley 1989 Serious mortality in populations of giant clams on reefs surrounding Lizard Island, Great Barrier Reef. Marine and Freshwater Research 40:205-213. https://doi.org/10.1071/ MF9890205

Anderson, C. and R. Robins 1988 Dismissed due to lack of evidence: Contemporary Kuku-Yalangi campsites and their significance. In B. Meehan and R. Jones (eds), Archaeology with Ethnography: An Australian Perspective, pp.182-205. Canberra: Department of Prehistory, Research School of Pacific Studies, Australian National University.

Arnold, O. 2020 The Rock Art of Lizard Island: A Preliminary Study of Dingaal Rock Art. Unpublished MA (Soc. Sci.) thesis, College of Arts, Society and Education, James Cook University, Cairns.

Ash, J., L. Manas and D. Bosun 2010 Lining the path: A seascape perspective of two Torres Strait missions, northeast Australia. International Journal of Historical Archaeology 14(1):56-85. https://doi.org/10.1007/s10761-009-0095-9

Aspinall, A., C. Gaffney and A. Schmidt 2008 Magnetometry for Archaeologists. Lanham, MD: AltaMira Press.

Attenbrow, V. 1992 Shell bed or shell midden. Australian Archaeology 34:3-21. https://doi.org/10.1080/03122417.1992. $\underline{11681447}$

Barham, A.J. 2000 Late Holocene maritime societies in the Torres Strait Islands, northern Australia-cultural arrival or cultural emergence? In S. O'Connor and P.M. Veth (eds), East of Wallace's Line: Studies of Past and Present Maritime Cultures of the IndoPacific Region, pp.223-314. Rotterdam: AA Balkema.

Barker, B. 1996 Maritime hunter-gatherers on the tropical coast: A social model for change. In S. Ulm, I. Lilley and A. Ross (eds), Australian Archaeology '95: Proceedings of the 1995 Australian Archaeological Association Annual Conference, pp.31-43. Tempus 6. St Lucia: Anthropology Museum, University of Queensland.

Barker, B. 2004 The Sea People: Late Holocene Maritime Specialisation in the Whitsunday Islands, Central Queensland. Terra Australis 20. Canberra: Pandanus Books, Australian National University.

Beaglehole, J. 1962 The Voyage of the Endeavour 1768-1771. Cambridge: Cambridge University Press for the Hakluyt Society.

Beaton, J.M. 1973 An Archaeological Reconnaissance of Some Islands of the Great Barrier Reef: A Survey Carried Out Under the Auspices of the Royal Society and Universities of Queensland Expedition to the Great Barrier Reef. Unpublished report to Royal Society and the Universities of Queensland, Brisbane.

Beaton, J.M. 1978 Archaeology and the Great Barrier Reef. Philosophical Transactions of the Royal Society of London B 284:141-147.

Beaton, J.M. 1985 Evidence for a coastal occupation time-lag at Princess Charlotte Bay (north Queensland) and implications for coastal colonization and population growth theories for Aboriginal Australia. Archaeology in Oceania 20(1):1-20. https://doi.org/ $\underline{\text { 10.1002/j.1834-4453.1985.tb00096.x }}$

Beesley, P.L., G.J.B. Ross and A. Wells (eds) 1998 Mollusca: The Southern Synthesis: Fauna of Australia. Melbourne: CSIRO Publishing.

Bellwood, D.R. 1994 A Phylogenetic Study of the Parrotfishes Family Scaridae (Pisces: Labroidei), with a Revision of Genera. Sydney: Australian Museum.
Bellwood, D.R., A.S. Hoey and J.H. Choat 2003 Limited functional redundancy in high diversity systems: Resilience and ecosystem function on coral reefs. Ecology Letters 6(4):281-285. https://doi.org/10.1046/j.1461-0248.2003.00432.x

Bellwood, D.R. and O. Schultz 1988 A review of the fossil record of the parrotfishes (Labroidei: Scaridae) with a description of a new Calotomus species from the Middle Miocene (Badenian) of Austria. Annalen des Naturhistorischen Museums in Wien. Serie A für Mineralogie und Petrographie, Geologie und Paläontologie, Anthropologie und Prähistorie 92:55-71.

Berkovitz, B. and R.P. Shellis 2016 The Teeth of Non-Mammalian Vertebrates. London: Academic Press.

Bevan, B.W. 1998 Geophysical Exploration for Archaeology: An Introduction to Geophysical Exploration. Midwest Archaeological Center Special Report 1. Lincoln: National Park Service, Midwest Archaeological Center.

Border, A. 1999 Aboriginal settlement of offshore islands in the Southern Great Barrier Reef Province, central Queensland. In J. Hall and I.J. McNiven (eds), Australian Coastal Archaeology, pp.129139. Research Papers in Archaeology and Natural History 31. Canberra: Archaeology and Natural History Publications, Research School of Pacific and Asian Studies, Australian National University.

Brady, L. 2010 Pictures, Patterns and Objects: Rock-Art of the Torres Strait Islands, Northeastern Australia. North Melbourne: Australian Scholarly Publishing.

Brady, L.M. and J. Ash 2018 New radiocarbon dates from Kirriri 4: Extending the 2,500 BP signature for the onset of the Torres Strait Cultural Complex to south western Torres Strait, northeast Queensland. Australian Archaeology 84(1):98-104. https://doi.org/ 10.1080/03122417.2018.1458271

Brady, L.M., W. Delaney and R. Robins 2013 The Queensland Museum expedition to Ngiangu (Booby Island): Rock art, archaeology and inter-regional interaction in south-western Torres Strait. Queensland Archaeological Research 16:93-120. https://doi.org/10.25120/qar.16.2013.225

Bronk Ramsey, C. 2009 Bayesian analysis of radiocarbon dates. Radiocarbon 51(1):337-360. https://doi.org/10.1017/ S0033822200033865

Bryant, L.M. 2013 Cryptic Diversity and Evolutionary Relationships among Australian Closed-Forest Melomys (Rodentia: Muridae) and related Australo-Papuan Mosaic-Tailed Rats. Unpublished PhD thesis, School of Earth, Environmental and Biological Sciences, Queensland University of Technology, Brisbane.

Butler, V.L. and R.A. Schroeder 1998 Do digestive processes leave diagnostic traces on fish bones. Journal of Archaeological Science 25(10):957-971. https://doi.org/10.1006/jasc.1997.0725

Byrnes, N.B., S.L. Everist, S.T. Reynolds, A. Specht and R.L. Specht 1977 The vegetation of Lizard Island, north Queensland. Proceedings of the Royal Society of Queensland 88:1-15.

Campbell, J.B. 1979 Settlement patterns on offshore islands in northeastern Queensland. Australian Archaeology 9:18-32. https://doi.org/10.1080/03122417.1979.12093357

Campbell, J.B. 1982a New radiocarbon results for north Queensland prehistory. Australian Archaeology 14:62-66. https://doi.org/ $\underline{10.1080 / 03122417.1982 .12092838}$

Campbell, J.B. 1982b Automatic seafood retrieval systems: The evidence from Hinchinbrook Island and its implications. In S. Bowdler (ed.), Coastal Archaeology in Eastern Australia: Proceedings of the 1980 Valla Conference on Australian Prehistory, pp.96-107. Occasional Papers in Prehistory 11. Canberra: Department of Prehistory, Research School of Pacific Studies, Australian National University. 
Carpenter, K.E. and V.H. Niem (eds) 1998 The Living Marine Resources of the Western Central Pacific, Vol. 1: Seaweeds, Corals, Bivalves and Gastropods. Rome: FAO.

Carter, M. 2004 North of the Cape and South of the Fly: The Archaeology of Settlement and Subsistence on the Murray Islands, Eastern Torres Strait. Unpublished $\mathrm{PhD}$ thesis, School of Anthropology, Archaeology and Sociology, James Cook University, Townsville.

Chambers, C.N. 2007 Pasua (Tridacna maxima) size and abundance in Tongareva Lagoon, Cook Islands. SPC Trochus Information Bulletin 13:7-12.

Chan, K., P. Todd and L. Chou 2008 An allometric analysis of juvenile fluted giant clam shells (Tridacna squamosa L.). Journal of Conchology 39(6):621-626.

Chappell, J., A. Chivas, E. Wallensky, H. Polach and P. Aharon 1983 Holocene palaeo-environmental changes, central to north Great Barrier Reef inner zone. BMR Journal of Australian Geology and Geophysics Canberra 8:223-235.

Clark, A. 1996 Seeing Beneath the Soil: Prospecting Methods in Archaeology. London: Routledge.

Clarkson, C. 2007 Lithics in the Land of the Lightning Brothers: The Archaeology of Wardaman Country, Northern Territory. Terra Australis 25. Canberra: ANU Press. http://doi.org/10.22459/ TA25.2007

Conroy, J.L., J.T. Overpeck, J.E. Cole, T.M. Shanahan and M. Steinitz-Kannan 2008 Holocene changes in eastern tropical Pacific climate inferred from a Galápagos lake sediment record. Quaternary Science Reviews 27(11):1166-1180. https://doi.org/10.1016/ j.quascirev.2008.02.015

Conyers, L.B. 2009 Ground-penetrating radar for landscape archaeology: Methods and applications. In S. Campana and S. Piro (eds), Seeing the Unseen, pp.245-255. London: Taylor and Francis.

Conyers, L.B. 2012 Interpreting Ground-Penetrating Radar for Archaeology. Walnut Creek: Left Coast Press.

Crouch, J. 2015 Small island, ‘big swamp', Kuiku Pad Reef: Sarbi 4200-3500 cal BP, western Torres Strait. Quaternary International 385:88-101. https://doi.org/10.1016/j.quaint.2015.02.011

Crouch, J., I.J. McNiven, B. David, C. Rowe and M. Weisler 2007 Berberass: Marine resource specialisation and environmental change in Torres Strait during the past 4000 years. Archaeology in Oceania 42(2):49-64. https://doi.org/10.1002/j.1834-4453.2007.tb00016.x

Dalan, R., J. Sturdevant, R. Wallace, B. Schneider and S. Vore 2017 Cutbank geophysics: A new method for expanding magnetic investigations to the subsurface using magnetic susceptibility testing at an Awatixa Hidatsa Village, North Dakota. Remote Sensing 9(2):112. https://doi.org/10.3390/rs9020112

Dalan, R.A. and S.K. Banerjee 1998 Solving archaeological problems using techniques of soil magnetism. Geoarchaeology: An International Journal 13(1):3-36. $\underline{\text { https://doi.org/10.1002/ }}$ (SICI)1520-6548(199801)13:1<3::AID-GEA2>3.0.CO;2-9

David, B., J. Crouch and U. Zoppi 2005 Historicizing the spiritual: $\mathrm{Bu}$ shell arrangements on the island of Badu, Torres Strait. Cambridge Archaeological Journal 15(1):71-91. https://doi.org/ 10.1017/S0959774305000041

David, B., I.J. McNiven, J. Crouch, Mura Badulgal Corporation Committee, R. Skelly, B. Barker, K. Courtney and G. Hewitt 2009 Koey Ngurtai: The emergence of a ritual domain in Western Torres Strait. Archaeology in Oceania 44(1):1-17. https://doi.org/10.1002/ j.1834-4453.2009.tb00040.x

David, B., I.J. McNiven, T. Richards, S.P. Connaughton, M. Leavesley, B. Barker and C. Rowe 2011 Lapita sites in the Central Province of mainland Papua New Guinea. World Archaeology 43(4):576-593. https://doi.org/10.1080/00438243.2011.624720
David, B. and M. Weisler 2006 Kurturniaiwak (Badu) and the archaeology of villages in Torres Strait. Australian Archaeology 63:21-34. https://doi.org/10.1080/03122417.2006.11681835

Dearing, J.A., K.L. Hay, S.M. Baban, A.S. Huddleston, E.M. Wellington and P. Loveland 1996 Magnetic susceptibility of soil: An evaluation of conflicting theories using a national data set. Geophysical Journal International 127(3):728-734. https://doi.org/ 10.1111/j.1365-246X.1996.tb04051.x

Dechnik, B., J.M. Webster, G.E. Webb, L. Nothdurft and J.-x. Zhao 2017 Successive phases of Holocene reef flat development: Evidence from the mid- to outer Great Barrier Reef. Palaeogeography, Palaeoclimatology, Palaeoecology 466:221-230. https://doi.org/https://doi.org/10.1016/j.palaeo.2016.11.030

Denham, T., C.B. Ramsey and J. Specht 2012 Dating the appearance of Lapita pottery in the Bismarck Archipelago and its dispersal to Remote Oceania. Archaeology in Oceania 47(1):39-46. https://doi.org/10.1002/j.1834-4453.2012.tb00113.x

Eichhorst, T.E. 2016 Neritidae of the World. Harxheim: ConchBooks.

Ellwood, B.B., K.M. Petruso, F.B. Harrold and J. Schuldenrein 1997 High-resolution paleoclimatic trends for the Holocene identified using magnetic susceptibility data from archaeological excavations in caves. Journal of Archaeological Science 24(6):569-573. https://doi.org/10.1006/jasc.1996.0140

Faith, J.T. 2013 Taphonomic and paleoecological change in the large mammal sequence from Boomplaas Cave, western Cape, South Africa. Journal of Human Evolution 65(6):715-730. https://doi.org/ $\underline{10.1016 / \text { j.jhevol.2013.09.001 }}$

Faith, J.T. and A. Du 2017 The measurement of taxonomic evenness in zooarchaeology. Archaeological and Anthropological Sciences 10:1419-1428. https://doi.org/10.1007/s12520-017-0467-8

Faulkner, P. 2010 Morphometric and taphonomic analysis of granular ark (Anadara granosa) dominated shell deposits of Blue Mud Bay, northern Australia. Journal of Archaeological Science 37(8):1942-1952. https://doi.org/10.1016/j.jas.2010.02.021

Faulkner, P., M. Harris, O. Haji, A.K. Ali, A. Crowther, C. Shipton, M.C. Horton and N. Boivin 2019 Long-term trends in terrestrial and marine invertebrate exploitation on the eastern African coast: Insights from Kuumbi Cave, Zanzibar. Journal of Island and Coastal Archaeology 14(4):479-514. https://doi.org/10.1080/15564894. $\underline{2018.1501442}$

Fitzpatrick, A., I.J. McNiven, J. Specht and S. Ulm 2018 Stylistic analysis of stone arrangements supports regional cultural interactions along the northern Great Barrier Reef, Queensland. Australian Archaeology 84(2):129-144. https://doi.org/10.1080/ $\underline{03122417.2018 .1507807}$

Frisch, A.J., M. Ireland, J.R. Rizzari, O.M. Lönnstedt, K.A. Magnenat, C.E. Mirbach and J.-P.A. Hobbs 2016 Reassessing the trophic role of reef sharks as apex predators on coral reefs. Coral Reefs 35(2):459-472. https://doi.org/10.1007/s00338-016-1415-2

Froese, R. and D. Pauly (eds) 2018 FishBase. Retrieved 1 December 2019 from www.fishbase.org.

Gaffney, C. and J. Gater 2003 Revealing the Buried Past: Geophysics for Archaeologists. Stroud: Tempus Publishing.

Gagan, M.K., E.J. Hendy, S.G. Haberle and W.S. Hantoro 2004 Postglacial evolution of the Indo-Pacific Warm Pool and El NiñoSouthern oscillation. Quaternary International 118-119:127-143. https://doi.org/10.1016/S1040-6182(03)00134-4

Genever, M., J. Grindrod and B. Barker 2003 Holocene palynology of Whitehaven Swamp, Whitsunday Island, Queensland, and implications for the regional archaeological record. Palaeogeography, Palaeoclimatology, Palaeoecology 201:141-156. https://doi.org/10.1016/S0031-0182(03)00542-X 
Ghaleb, B. 1990 An Ethnoarchaeological Study of Mabuiag Island, Torres Strait, Northern Australia. Unpublished $\mathrm{PhD}$ thesis, University College London, London.

Gilbert, A., G. Remoissenet, L. Yan and S. Andrefouet 2006 Special traits and promises of the giant clam (Tridacna maxima) in French Polynesia. Fisheries Newsletter-South Pacific Commission 118:44.

Giovas, C.M. 2009 The shell game: Analytic problems in archaeological mollusc quantification. Journal of Archaeological Science 36(7):1557-1564. https://doi.org/10.1016/j.jas.2009.03.017

Giovas, C.M. 2018 Pre-Columbian Amerindian lifeways at the Sabazan site, Carriacou, West Indies. The Journal of Island and Coastal Archaeology 13(2):161-190. https://doi.org/10.1080/ $\underline{15564894.2016 .1229702}$

Goatley, C.H. and D.R. Bellwood 2012 Sediment suppresses herbivory across a coral reef depth gradient. Biology Letters 8(6):1016-1018. https://doi.org/10.1098/rsbl.2012.0770

Goatley, C.H.R., A.S. Hoey and D.R. Bellwood 2012 The role of turtles as coral reef macroherbivores. PloS ONE 7(6):e39979. https://doi.org/10.1371/journal.pone.0039979

Goodman, D. and S. Piro 2013 GPR Remote Sensing in Archaeology. New York: Springer.

Grayson, D.K. 1984 Quantitative Zooarchaeology: Topics in the Analysis of Archaeological Faunas. Orlando: Academic Press.

Greer, S., R. Henry and S. McIntyre-Tamwoy 2015 Mainland magic: Interpreting cultural influences across Cape York-Torres Strait. Quaternary International 385:69-78.

Grimm, E.C. 2004 TGView Version 2.0.2. Springfield, IL: Illinois State Museum.

Grindrod, J. 1985 The palynology of mangroves on a prograded shore, Princess Charlotte Bay, North Queensland, Australia. Journal of Biogeography 12:323-348.

Haddon, A.C. 1935 Reports of the Cambridge Anthropological Expedition to Torres Straits, Vol. 1: General Ethnography. Cambridge: Cambridge University Press.

Hammer, Ø., D.A.T. Harper and P.D. Ryan 2001 PAST: Paleontological statistics software package for education and data analysis. Palaeontologia Electronica 4(1):1-9.

Hammond, H. 2014 Taphonomic analysis of archaeomalacological assemblages: Shell middens on the northern coast of Santa Cruz (Patagonia, Argentina). Intersecciones en Antropología 15(1):2134.

Hamylton, S.M., J.X. Leon, M.I. Saunders and C.D. Woodroffe 2014 Simulating reef response to sea-level rise at Lizard Island: A geospatial approach. Geomorphology 222:151-161. https://doi.org/ $\underline{10.1016 / \text { j.geomorph.2014.03.006 }}$

Harris, M., P. Faulkner and B. Asmussen 2017 Macroscopic approaches to the identification of expedient bivalve tools: A case study investigating Polymesoda (=Geloina) coaxans (Bivalvia: Corbiculidae) shell valves from Princess Charlotte Bay, Queensland, Australia. Quaternary International 427:201-215. https://oi.org/ $\underline{10.1016 / \text { j.quaint.2015.08.020 }}$

Harris, M., A.B.J. Lambrides and M.I. Weisler 2016 Windward vs. leeward: Inter-site variation in marine resource exploitation on Ebon Atoll, Republic of the Marshall Islands. Journal of Archaeological Science: Reports 6:221-229. https://doi.org/10.1016/i.jasrep. $\underline{2016.02 .012}$

Harris, M. and M. Weisler 2018 Two millennia of mollusc foraging on Ebon Atoll, Marshall Islands: Sustained marine resource use on a Pacific atoll. Archaeology in Oceania 53(1):41-57. https://doi.org/ $\underline{10.1002 / \operatorname{arco} .5134}$
Harris, M., M. Weisler and P. Faulkner 2015 A refined protocol for calculating MNI in archaeological molluscan shell assemblages: A Marshall Islands case study. Journal of Archaeological Science 57:168-179. https://doi.org/10.1016/j.jas.2015.01.017

Hayek, L.-A.C. and M.A. Buzas 2010 Surveying Natural Populations: Quantitative Tools for Assessing Biodiversity. New York: Columbia University Press.

Herries, A.I. and E.C. Fisher 2010 Multidimensional GIS modeling of magnetic mineralogy as a proxy for fire use and spatial patterning: Evidence from the Middle Stone Age bearing sea cave of Pinnacle Point 13B (Western Cape, South Africa). Journal of Human Evolution 59(3-4):306-320. https://doi.org/10.1016/j.jhevol. $\underline{2010.07 .012}$

Hinton, A.G. 1972 Shells of New Guinea and the Central IndoPacific. Port Moresby: Robert Brown and Associates.

Hiscock, P. 1996 Mobility and technology in the Kakadu coastal wetlands. Bulletin of the Indo-Pacific Prehistory Association 15:151-157.

Hoey, A. and D. Bellwood 2008 Cross-shelf variation in the role of parrotfishes on the Great Barrier Reef. Coral Reefs 27(1):37-47. https://doi.org/10.1007/s00338-007-0287-x

Huber, M. 2010 Compendium of Bivalves. Hackenheim: ConchBooks.

Jacob, R.W. and T.M. Urban 2015 Ground-penetrating radar velocity determination and precision estimates using common-mid-point (CMP) collection with hand-picking, semblance analysis, and crosscorrelation analysis: A case study and tutorial for archaeologists. Archaeometry 58(6):987-1002. https://doi.org/10.1111/arcm.12214

Jameson, S.C. 1976 Early life history of the giant clams Tridacna crocea Lamarck, Tridacna maxima (Roding), and Hippopus hippopus (Linnaeus). Pacific Science 30:219-233.

Jarrett, A.G. 2011 Marine Shells of the Whitsunday Coast \& Islands. Australia: Alan G. Jarrett Publishing.

Jerardino, A. and C.W. Marean 2010 Shellfish gathering, marine paleoecology and modern human behavior: Perspectives from cave PP13B, Pinnacle Point, South Africa. Journal of Human Evolution 59(3):412-424. https://doi.org/10.1016/j.jhevol.2010.07.003

Kinsey, D.W. 1979 Carbon Turnover and Accumulation by Coral Reefs. Unpublished PhD thesis, University of Hawaii, Manoa.

Laade, W. 1969 Ethnographic notes on the Murray Islanders, Torres Strait. Zeitschrift fur Ethnologie 94(1):33-46.

Lamb, L. and B. Barker 2001 Evidence for early Holocene change in the Whitsunday Islands: A new radiocarbon determination from Nara Inlet 1. Australian Archaeology 53:42-43. https://doi.org/ $\underline{10.1080 / 03122417.2001 .11681722}$

Lambeck, K. and M. Nakada 1990 Late Pleistocene and Holocene sea-level change along the Australian coast. Palaeogeography, Palaeoclimatology, Palaeoecology 89(1-2):143-176. https://doi.org/10.1016/0921-8181(90)90060-P

Lambrides, A.B.J., I.J. McNiven and S. Ulm 2019 Meta-analysis of Queensland's coastal Indigenous fisheries: Examining the archaeological evidence for geographic and temporal patterning. Journal of Archaeological Science: Reports 28:102057. https://doi.org/10.1016/i.jasrep.2019.102057

Lambrides, A.B.J. and M.I. Weisler 2016 Pacific Islands ichthyoarchaeology: Implications for the development of prehistoric fishing studies and global sustainability. Journal of Archaeological Research 24(3):275-324. https://doi.org/10.1007/s10814-016-9090$\mathrm{y}$ 
Lambrides, A.B.J., M.I. Weisler and M. Charleux 2018 New taxonomic records and regional trends for the Marquesan prehistoric marine fishery, Eiao Island, Polynesia. Journal of Pacific Archaeology 9(1):44-62.

Leis, J. 1986 Vertical and horizontal distribution of fish larvae near coral reefs at Lizard Island, Great Barrier Reef. Marine Biology 90(4):505-516. https://doi.org/10.1007/BF00409271

Lentfer, C.J., M.W. Felgate, R.A. Mills and J. Specht 2013 Human history and palaeoenvironmental change at Site 17, Freshwater Beach, Lizard Island, northeast Queensland, Australia. Queensland Archaeological Research 16:141-164. https://doi.org/10.25120/ qar.16.2013.227

Leonard, N.D., M.L. Lepore, J.X. Zhao, A. Rodriguez-Ramirez, I.R. Butler, T.R. Clark, G. Roff, L. McCook, A.D. Nguyen, Y. Feng and J.M. and Pandolfi 2020. Re-evaluating mid-Holocene reef "turn-off" on the inshore Southern Great Barrier Reef. Quaternary Science Reviews 244:106518. https://doi.org/10.1016/j.quascirev.2020. $\underline{106518}$

Lewis, S.E., C.R. Sloss, C.V. Murray-Wallace, C.D. Woodroffe and S.G. Smithers 2013 Post-glacial sea-level changes around the Australian margin: A review. Quaternary Science Reviews 74:115138. https://doi.org/10.1016/j.quascirev.2012.09.006

Lewis, S.E., R.A.J. Wüst, J.M. Webster, J. Collins, S.A. Wright and G. Jacobsen 2015 Rapid relative sea-level fall along north-eastern Australia between 1200 and 800 cal. yr BP: An appraisal of the oyster evidence. Marine Geology 370:20-30. https://doi.org/ 10.1016/j.margeo.2015.09.014

Linford, N., P. Linford and E. Platzman 2005 Dating environmental change using magnetic bacteria in archaeological soils from the upper Thames Valley, UK. Journal of Archaeological Science 32(7):1037-1043. https://doi.org/10.1016/j.jas.2005.01.017

Llewelyn, J., L. Schwarzkopf, B.L. Phillips and R. Shine 2014 After the crash: How do predators adjust following the invasion of a novel toxic prey type? Austral Ecology 39(2):190-197. https://doi.org/ $\underline{10.1111 / \mathrm{aec} .12058}$

Lucas, K.G. 1965 Cape Melville, Queensland. Geology and Geophysics Geological Series Sheet SD/55-9, Scale 1:250,000. Canberra: Australian Bureau of Mineral Resources.

Lyman, R.L. 2008 Quantitative Paleozoology. New York: Cambridge University Press.

Macgillivray, J. 1852 Narrative of the Voyage of H.M.S. Rattlesnake, Commanded by the Late Captain Owen Stanley during the Years 1846-50. London: T. \& W. Boone.

Madin, J.S., K.P. Black and S.R. Connolly 2006 Scaling water motion on coral reefs: From regional to organismal scales. Coral Reefs 25(4):635-644. https://doi.org/10.1007/s00338-006-0137-2

Magurran, A.E. 2004 Measuring Biological Diversity. Malden, MA: Blackwell Publishing.

Maher, B.A. and R.M. Taylor 1988 Formation of ultrafine-grained magnetite in soils. Nature 336(6197):368-370. https://doi.org/ $10.1038 / 336368 \mathrm{a} 0$

Marshall, T.C. 1965 Fishes of the Great Barrier Reef and Coastal Waters of Queensland. Sydney: Angus and Robertson.

McCarthy, F.D. 1939 "Trade" in Aboriginal Australia, and "trade" relationships with Torres Strait, New Guinea and Malaya. Oceania 9(4):405-438. https://doi.org/10.1002/j.1834-4461.1939.tb00247.x

McKenzie, L., W.L. Long and E. Bradshaw 1997 Distribution of Seagrasses in the Lizard Island Group: A Reconnaissance Survey, October 1995. Technical Report 14. Cairns: CRC Reef Research Centre.
McNiven, I.J. 2006 Dauan 4 and the emergence of ethnographicallyknown social arrangements across Torres Strait during the last 600800 years. Australian Archaeology 62:1-12. https://doi.org/10.1080/ $\underline{03122417.2006 .11681825}$

McNiven, I.J. 2015 Precarious islands: Kulkalgal reef island settlement and high mobility across $700 \mathrm{~km}$ of seascape, central Torres Strait and northern Great Barrier Reef. Quaternary International 385:39-55. https://doi.org/10.1016/j.quaint.2014. $\underline{09.015}$

McNiven, I.J. 2019 Beyond bridge and barrier: Torres Strait and curious artefact distributions between Queensland and New Guinea. Oceanic Art Society 24(3):3-6.

McNiven, I.J., B. David, Goemulgau Kod and J. Fitzpatrick 2009 The great kod of Pulu: Mutual historical emergence of ceremonial sites and social groups in Torres Strait, northeast Australia. Cambridge Archaeological Journal 19(3):291-317. https://doi.org/ 10.1017/S095977430900050X

McNiven, I.J., B. David, T. Richards, K. Aplin, B. Asmussen, J. Mialanes, M. Leavesley, P. Faulkner and S. Ulm 2011 New direction in human colonisation of the Pacific: Lapita settlement of south coast New Guinea. Australian Archaeology 72:1-6. https://doi.org/ $\underline{10.1080 / 03122417.2011 .11690525}$

McNiven, I.J., N. De Maria, M. Weisler and T. Lewis 2014 Darumbal voyaging: Intensifying use of central Queensland's Shoalwater Bay islands over the past 5000 years. Archaeology in Oceania 49(1):2-42. https://doi.org/10.1002/arco.5016

McNiven, I.J., W.R. Dickinson, B. David, M.I. Weisler, F. Von Gnielinski, M. Carter and U. Zoppi 2006 Mask Cave: Red-slipped pottery and the Australian-Papuan settlement of Zenadh Kes (Torres Strait). Archaeology in Oceania 41(2):49-81. https://doi.org/ 10.1002/j.1834-4453.2006.tb00610.x

McNiven, I.J. and R. Feldman 2003 Ritually orchestrated seascapes: Hunting magic and dugong bone mounds in Torres Strait, NE Australia. Cambridge Archaeological Journal 13(2):169-194. https://doi.org/10.1017/S0959774303000118

McNiven, I.J., F.E. von Gnielinski and M. Quinnell 2004 Torres Strait and the origin of large stone axes from Kiwai Island, Fly River estuary (Papua New Guinea). In I.J. McNiven and M. Quinnell (eds), Torres Strait Archaeology and Material Culture, pp.271-289. Memoirs of the Queensland Museum, Cultural Heritage Series 3. Brisbane: Queensland Museum.

McNiven, I.J. and D. Wright 2008 Ritualised marine midden formation in western Zenadh Kes (Torres Strait). In G. Clark, F. Leach and S. O'Connor (eds), Islands of Inquiry: Colonisation, Seafaring and the Archaeology of Maritime Landscapes, pp.133147. Terra Australis 29. Canberra: ANU E Press. http://doi.org/10.22459/TA29.06.2008.09

McNiven, I.J., D. Wright, S. Sutton, M.I. Weisler, S. Hocknull and J. Stanisic 2015 Midden formation and marine specialisation at Goemu village, Mabuyag (Torres Strait) before and after European contact. In I.J. McNiven and G. Hitchcock (eds), Goemulgaw Lagal: Cultural and Natural Histories of the Island of Mabuyag, Torres Strait, pp.377-475. Memoirs of the Queensland Museum - Culture 8(2). Brisbane: Queensland Museum.

Mills, R.A. 1992 Aboriginal Occupation of Lizard Island. Unpublished MA thesis, Department of Archaeology, University of Sydney, Sydney.

Mills, R.A. 1995a Cultural Heritage Study of the Clynder Sub-Lease, Lizard Island. Unpublished report to Department of Environment and Heritage, Queensland Government, Brisbane.

Mills, R.A. 1995b Archaeological Survey of the Proposed Extension to the Lizard Island Lodge Resort. Unpublished report to Suncorp, Brisbane. 
Moore, C. 2000 Refocusing indigenous trade and power: The dynamics of early foreign contact and trade in Torres Strait, Cape York and Southeast New Guinea in the nineteenth century. Journal of the Royal Historical Society of Queensland 17(7):289-302.

Moore, P. 2005 Plants of Inland Australia. Sydney: Reed New Holland.

Moss, P.T., S. Ulm, L. Mackenzie, L.A. Wallis, D. Rosendahl and L. Steinberger 2019 Robust local vegetation records from dense archaeological shell matrixes: A palynological analysis of the Thundiy shell deposit, Bentinck Island, Gulf of Carpentaria, Australia. Archaeological and Anthropological Sciences 11(2):511520. https://doi.org/10.1007/s12520-016-0394-0

Mullins, C.E. 1974 The magnetic properties of the soil and their applications to archaeological prospecting. Archaeo-Physika 5:143347.

Myers, R.F. 1999 Micronesian Reef Fishes: A Comprehensive Guide to the Coral Reef Fishes of Micronesia. Barrigada: Coral Graphics.

Nakada, M. and K. Lambeck 1989 Late Pleistocene and Holocene sea-level change in the Australian region and mantle rheology. Geophysical Journal International 96(3):497-517.

O'Connor, S., T. Maloney, D. Vannieuwenhuyse, J. Balme and R. Wood 2014 Occupation at Carpenters Gap 3, Windjana Gorge, Kimberley, Western Australia. Australian Archaeology 78:10-23. https://doi.org/10.1080/03122417.2014.11681994

Orme, G.R. and P.G. Flood 1977 The geological history of the Great Barrier Reef: A reappraisal of some aspects in the light of new evidence. Proceedings of 3rd International Coral Reef Symposium 2:37-43.

Perry, C.T. and S.G. Smithers 2011 Cycles of coral reef 'turn-on', rapid growth and 'turn-off'over the past 8500 years: A context for understanding modern ecological states and trajectories. Global Change Biology 17(1):76-86. https://doi.org/10.1111/j.13652486.2010.02181.x

Proske, U. and S.G. Haberle 2012 Island ecosystem and biodiversity dynamics in northeastern Australia during the Holocene: Unravelling short-term impacts and long-term drivers. The Holocene 22(10):1097-1111. https://doi.org/10.1177/0959683612441840

Randall, J.E., G.R. Allen and R.C. Steene 1997 Fishes of the Great Barrier Reef and Coral Sea. Bathurst: Crawford House Publishing.

Reef, R., I.C. Feller and C.E. Lovelock 2014 Mammalian herbivores in Australia transport nutrients from terrestrial to marine ecosystems via mangroves. Journal of Tropical Ecology 30(3):179-188. https://doi.org/10.1017/S0266467414000054

Rees, S.A., B.N. Opdyke, P.A. Wilson, L.K. Fifield and V. Levchenko 2006 Holocene evolution of the granite based Lizard Island and MacGillivray reef systems, Northern Great Barrier Reef. Coral Reefs 25(4):555-565. https://doi.org/10.1007/s00338-006$\underline{0138-1}$

Reimer, P.J., E. Bard, A. Bayliss, J.W. Beck, P.G. Blackwell, C.B. Ramsey, C.E. Buck, H. Cheng, R.L. Edwards and M. Friedrich 2013 IntCal13 and Marine13 radiocarbon age calibration curves $0-50,000$ years cal BP. Radiocarbon 55(4):1869-1887. https://doi.org/ $\underline{10.2458 / a z u}$ js_rc. 55.16947

Reitz, E.J. and E.S. Wing 2008 Zooarchaeology. Cambridge: Cambridge University Press.

Robertson, R. 1981 List of shell-bearing mollusks observed and collected at Lizard Island, Great Barrier Reef, Australia. Tryonia 4:1-32.

Rowland, M.J. 1980 The Keppel Islands - Preliminary investigations. Australian Archaeology 11:1-17. https://doi.org/ $\underline{10.1080 / 03122417.1980 .12092770}$
Rowland, M.J. 1981 Radiocarbon dates for a shell fishhook and disc from Mazie Bay, North Keppel Island. Australian Archaeology 12:63-69. https://doi.org/10.1080/03122417.1981.12092800

Rowland, M.J. 1982 Further radiocarbon dates from the Keppel Islands. Australian Archaeology 15:43-48. https://doi.org/10.1080/ $\underline{03122417.1982 .12092857}$

Rowland, M.J. 1984 A long way in a bark canoe: Aboriginal occupation of the Percy Isles. Australian Archaeology 18:7-31. https://doi.org/10.1080/03122417.1984.12092928

Rowland, M.J. 1985 Further radiocarbon dates from Mazie Bay, North Keppel Island. Australian Archaeology 21:113-118. https://doi.org/10.1080/03122417.1985.12093020

Rowland, M. 1987 The distribution of Aboriginal watercraft on the east coast of Queensland: Implications for culture contact. Australian Aboriginal Studies 2:38-45.

Rowland, M.J. 1996 Prehistoric archaeology of the Great Barrier Reef Province: Retrospect and prospect. In P.M. Veth and P. Hiscock (eds), Archaeology of Northern Australia: Regional Perspectives, pp.191-211. Tempus 4. Brisbane: Anthropology Museum, University of Queensland.

Rowland, M.J. 1999 The Keppel Islands - “A 3000 year" event revisited. In J. Hall and I.J. McNiven (eds), Australian Coastal Archaeology, pp.141-151. Research Papers in Archaeology and Natural History 31. Canberra: Archaeology and Natural History Publications, Research School of Pacific and Asian Studies, Australian National University.

Saunders, M.I., E. Bayraktarov, C.M. Roelfsema, J.X. Leon, J. Samper-Villarreal, S.R. Phinn, C.E. Lovelock and P.J. Mumby 2015 Spatial and temporal variability of seagrass at Lizard Island, Great Barrier Reef. Botanica Marina 58(1):35-49. https://doi.org/10.1515/ bot-2014-0060

Sim, R. and L. Wallis 2008 Northern Australian offshore island use during the Holocene: The archaeology of Vanderlin Island, Sir Edward Pellew Group, Gulf of Carpentaria. Australian Archaeology 67:95-106. https://doi.org/10.1080/03122417.2008.11681882

Smith, G.C. and R. Buckley 1986 Eagle Island, Great Barrier Reef, Queensland. Seabird Islands Series 161:81-83.

Smith, G.C. 1987 The birds of Eagle Island, a tropical sand cay on the northern Great Barrier Reef, Australia. The Sunbird 17(1):1-11.

Smith, T. and I.J. McNiven 2019 Aboriginal marine subsistence foraging flexibility in a dynamic estuarine environment: The late development of Tin Can Inlet (southeast Queensland) middens revisited. Queensland Archaeological Research 22:1-38. https://doi.org/10.25120/qar.22.2019.3670

Specht, J. 1978 An Archaeological Survey of Lizard Island, Queensland. Unpublished report to Trustees of the Australian Museum, Sydney.

Tallavaara, M., M.A. Manninen, E. Hertell and T. Rankama 2010 How flakes shatter: A critical evaluation of quartz fracture analysis. Journal of Archaeological Science 37(10):2442-2448. https://doi.org/10.1016/j.jas.2010.05.005

Thompson, R. and F. Oldfield 1986 Environmental Magnetism. London: Allen and Unwin.

Tite, M.S. and C. Mullins 1971 Enhancement of the magnetic susceptibility of soils on archaeological sites. Archaeometry 13(2):209-219. https://doi.org/10.1111/j.1475-4754.1971.tb00043.x

Tochilin, C., W.R. Dickinson, M.W. Felgate, M. Pecha, P. Sheppard, F.H. Damon, S. Bickler and G.E. Gehrels 2012 Sourcing temper sands in ancient ceramics with $\mathrm{U}-\mathrm{Pb}$ ages of detrital zircons: A southwest Pacific test case. Journal of Archaeological Science 39(7):2583-2591. https://doi.org/10.1016/j.jas.2012.04.002 
Tomkins, H., D. Rosendahl and S. Ulm 2013 Tropical Archaeology Research Laboratory comparative fish reference collection: Developing a resource for identifying marine fish remains in archaeological deposits in tropical Australasia. Queensland Archaeological Research 16:1-14. https://doi.org/10.25120/ gar.16.2013.220

Ulm, S. 2006 Australian marine reservoir effects: A guide to $\Delta \mathrm{R}$ values. Australian Archaeology 63:57-60. https://doi.org/10.1080/ $\underline{03122417.2006 .11681838}$

Ulm, S. 2011 Coastal foragers on southern shores: Marine resource use in northeast Australia since the late Pleistocene. In N.F. Bicho, J.A. Haws and L.G. Davis (eds), Trekking the Shore: Changing Coastlines and the Antiquity of Coastal Settlement, pp.441-461. New York: Springer. https://doi.org/10.1007/978-1-4419-8219$\underline{319}$

Ulm, S. 2013 'Complexity' and the Australian continental narrative: Themes in the archaeology of Holocene Australia. Quaternary International 285:182-192. https://doi.org/10.1016/j.quaint. $\underline{2012.03 .046}$

Ulm, S., I.J. McNiven, S. Aird and A.B.J. Lambrides 2019 Sustainable harvesting of Conomurex luhuanus and Rochia nilotica by Indigenous Australians on the Great Barrier Reef over the past 2000 years. Journal of Archaeological Science: Reports 28:102017. https://doi.org/10.1016/j.jasrep.2019.102017

van der Kaars, W. 1991 Palynology of eastern Indonesian marine piston-cores: A Late Quaternary vegetational and climatic record for Australasia. Palaeogeography, Palaeoclimatology, Palaeoecology 85(3-4):239-302. https://doi.org/10.1016/0031-0182(91)90163-L

Williams, A.N., S. Ulm, T. Sapienza, S. Lewis and C.S.M. Turney 2018 Sea-level change and demography during the last glacial termination and early Holocene across the Australian continent. Quaternary Science Reviews 182:144-154. https://doi.org/10.1016/ j.quascirev.2017.11.030

Witten, A.J. 2006 Handbook of Geophysics and Archaeology. London: Equinox Publishing.

Wolverton, S. 2013 Data quality in zooarchaeological faunal identification. Journal of Archaeological Method and Theory 20(3):381-396. https://doi.org/10.1007/s10816-012-9161-4
Wright, D., P. Hiscock and K. Aplin 2013 Re-excavation of Dabangay, a mid-Holocene settlement site on Mabuyag in western Torres Strait. Queensland Archaeological Research 16:15-32. https://doi.org/10.25120/qar.16.2013.221

Wright, M. 2018 Rocky Shores, Mud, and Mangroves: An Assessment of Economic Intensification at the Yindayin Rockshelter, Stanley Island. Unpublished BA (Hons) thesis, Department of Archaeology, The University of Sydney, Sydney.

Wright, S.A. 2011 Fixed Intertidal Biological Indicators and Holocene Sea-Level on the Great Barrier Reef Coast. Unpublished $\mathrm{PhD}$ thesis, University of New England, Armidale.

Wyneken, J. 2003 The external morphology, musculoskeletal system, and neuro-anatomy of sea turtles. In P.L. Lutz, J.A. Musick and J. Wyneken (eds), The Biology of Sea Turtles, pp.39-77. Florida: CRC Press.

Zwartz, D.P. 1995 The Recent History of the Antarctic Ice Sheet: Constraints from Sea-Level Change. Unpublished $\mathrm{PhD}$ thesis, Australian National University, Canberra.

Citation: Lambrides, A.B.J., I.J. McNiven, S.J. Aird, K.A. Lowe, P. Moss, C. Rowe, C. Harris, C. Maclaurin, S.A. Slater, K. Carroll, M.H. Cedar, F. Petchey, C. Reepmeyer, M. Harris, J. Charlie, E. McGreen, P. Baru and S. Ulm 2020 Changing use of Lizard Island over the past 4000 years and implications for understanding Indigenous offshore island use on the Great Barrier Reef. Queensland Archaeological Research 23:43-109. https://doi.org/ $\underline{10.25120 / \text { qar.23.2020.3778 }}$ 


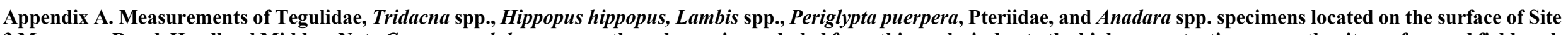

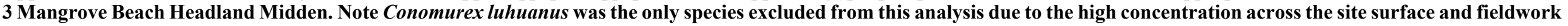
time constraints.

\begin{tabular}{|c|c|c|c|c|c|c|c|}
\hline \multirow[b]{2}{*}{ Taxon } & & \multicolumn{2}{|c|}{$n$} & \multicolumn{2}{|c|}{$\begin{array}{l}\text { Mean } \\
(\mathrm{mm})\end{array}$} & \multicolumn{2}{|c|}{$\begin{array}{c}\text { Range } \pm \text { s.d. }(\sigma) \\
(\mathrm{mm})\end{array}$} \\
\hline & & Width/ Height & $\begin{array}{c}\text { Length/ Base } \\
\text { Diameter }\end{array}$ & Width/ Height & $\begin{array}{c}\text { Length/ Base } \\
\text { Diameter }\end{array}$ & Width/ Height & $\begin{array}{c}\text { Length/ Base } \\
\text { Diameter } \\
\end{array}$ \\
\hline \multirow[t]{3}{*}{ Gastropoda } & Strombidae & & & & & & \\
\hline & Lambis spp. & 2 & 2 & 47.5 & 115.0 & $45.0-50.0 \pm 3.5$ & $100.0-130.0 \pm 21.2$ \\
\hline & Tegulidae & 49 & 417 & 73.8 & 89.9 & $38.0-110.0 \pm 17.2$ & $35.0-130.0 \pm 18.2$ \\
\hline \multirow[t]{2}{*}{ Bivalvia } & Arcidae & & & & & & \\
\hline & Anadara spp. & 21 & 21 & 48.6 & 71.1 & $38.0-60.0 \pm 5.6$ & $50.0-90.0 \pm 9.2$ \\
\hline \multicolumn{8}{|c|}{ Cardiidae } \\
\hline & Hippopus hippopus & 4 & 4 & 78.9 & 110 & $70.0-100.0 \pm 14.4$ & $100.0-130.0 \pm 14.1$ \\
\hline & Tridacna spp. & 350 & 352 & 70.6 & 125.1 & $40.0-120.0 \pm 14.7$ & $70.0-230.0 \pm 25.7$ \\
\hline & Pteriidae & 1 & 1 & 80.0 & 95.0 & - & - \\
\hline \multicolumn{8}{|c|}{ Veneridae } \\
\hline & Periglypta puerpera & 1 & 1 & 50.0 & 50.0 & - & - \\
\hline
\end{tabular}


Appendix B. Summary excavation data and retained materials, Site 3 Mangrove Beach Headland Midden, Square A.

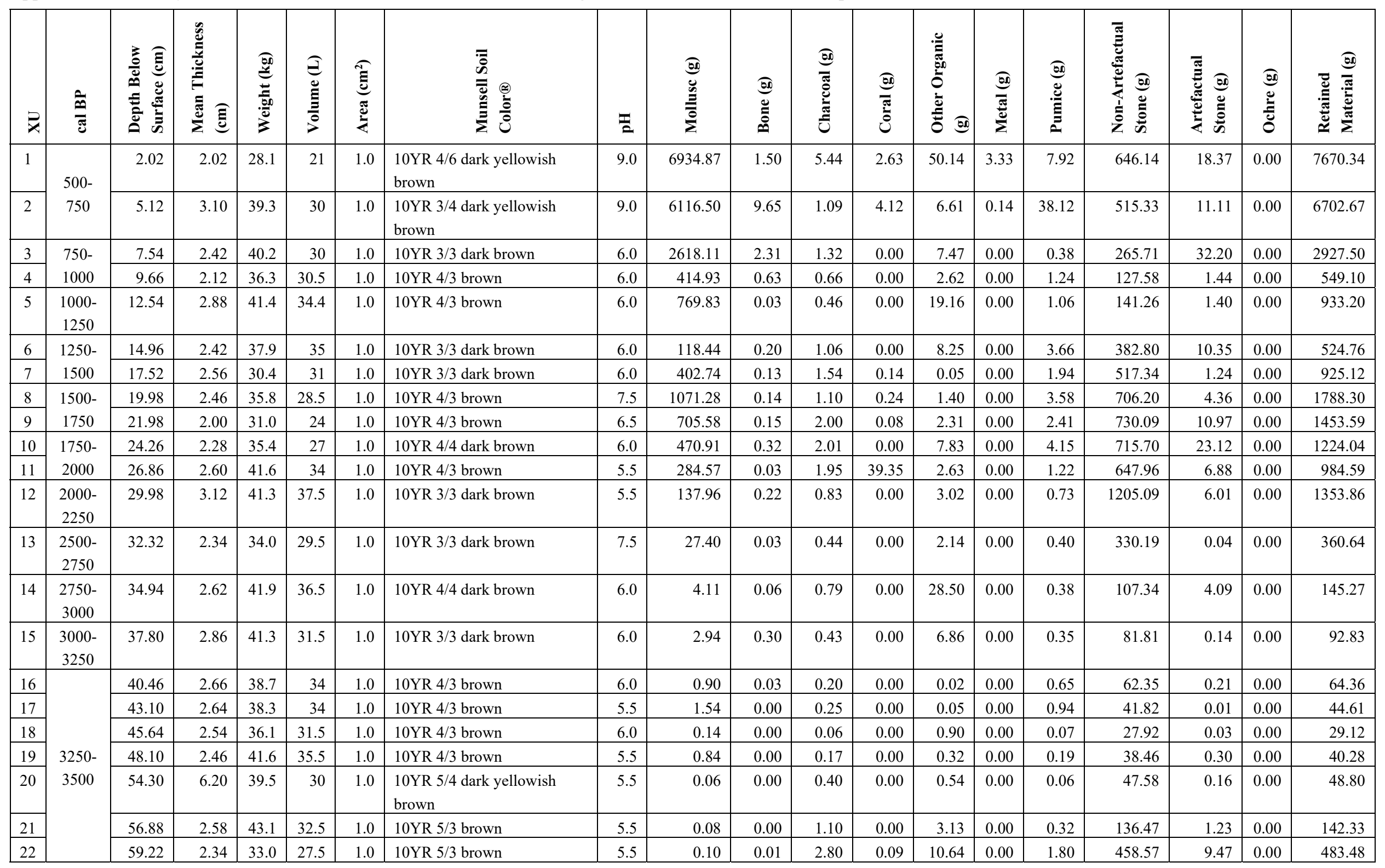


Appendix B. Summary excavation data and retained materials, Site 3 Mangrove Beach Headland Midden, Square A (cont.).

\begin{tabular}{|c|c|c|c|c|c|c|c|c|c|c|c|c|c|c|c|c|c|c|c|}
\hline 2 & $\hat{\bar{x}}$ & 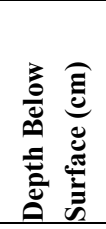 & 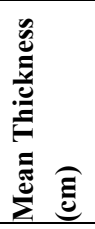 & 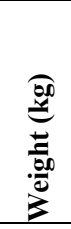 & 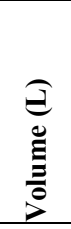 & 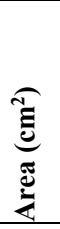 & 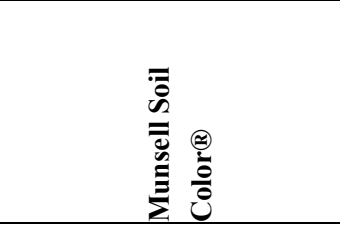 & 플 & 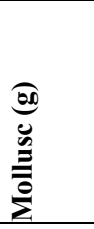 & 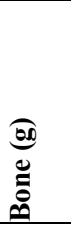 & 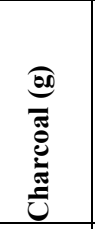 & ब0త0 & 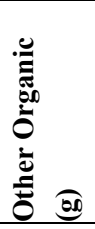 & 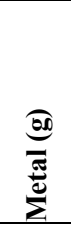 & 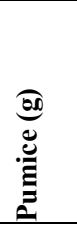 & 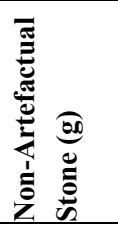 & 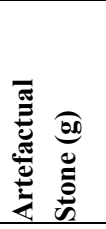 & 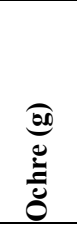 & 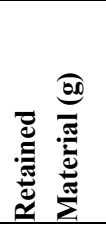 \\
\hline 23 & \multirow{9}{*}{$\begin{array}{l}3250- \\
3500\end{array}$} & 61.08 & 1.86 & 29.1 & 21.5 & 1.0 & 10YR 4/3 brown & 6.0 & 0.06 & 0.00 & 6.09 & 0.00 & 3.79 & 0.00 & 2.94 & 1252.20 & 15.80 & 3.10 & 1283.98 \\
\hline 24 & & 63.84 & 2.76 & 36.7 & 29.5 & 1.0 & 10YR 4/3 brown & 5.5 & 0.24 & 0.06 & 12.87 & 0.00 & 3.58 & 0.00 & 2.21 & 1532.08 & 8.09 & 0.00 & 1559.13 \\
\hline 25 & & 66.10 & 2.26 & 39.0 & 30.5 & 1.0 & 10YR 3/3 dark brown & 6.5 & 0.00 & 0.08 & 6.60 & 0.00 & 6.41 & 0.00 & 0.40 & 1544.83 & 1.55 & 0.00 & 1559.87 \\
\hline 26 & & 68.76 & 2.66 & 34.6 & 31 & 1.0 & 10YR 3/3 dark brown & 5.5 & 0.02 & 0.00 & 2.07 & 0.00 & 16.99 & 0.00 & 0.45 & 299.37 & 0.55 & 0.00 & 319.45 \\
\hline 27 & & 70.32 & 1.56 & 23.5 & 20 & 1.0 & 10YR 3/3 dark brown & 5.5 & 0.00 & 0.02 & 1.12 & 0.00 & 8.02 & 0.00 & 0.01 & 123.29 & 0.04 & 0.00 & 132.50 \\
\hline 28 & & 72.42 & 2.10 & 34.0 & 31 & 1.0 & 10YR 4/3 brown & 5.5 & 15.42 & 0.05 & 1.04 & 0.01 & 8.78 & 0.00 & 0.20 & 60.47 & 1.43 & 0.00 & 87.40 \\
\hline 29 & & 75.20 & 2.78 & 44.7 & 41 & 1.0 & 10YR 3/3 dark brown & 5.5 & 0.26 & 0.00 & 0.66 & 0.00 & 6.43 & 0.00 & 1.82 & 210.06 & 0.73 & 0.00 & 219.96 \\
\hline 30 & & 77.98 & 2.78 & 39.1 & 32.5 & 1.0 & 10YR 3/3 dark brown & 6.0 & 0.59 & 0.00 & 5.41 & 0.00 & 7.24 & 0.00 & 0.44 & 320.07 & 3.50 & 0.00 & 337.25 \\
\hline 31 & & 80.26 & 2.28 & 25.6 & 24.5 & 1.0 & 10YR 4/3 brown & 6.0 & 0.06 & 0.00 & 0.23 & 0.00 & 0.86 & 0.00 & 0.11 & 69.28 & 0.00 & 0.00 & 70.54 \\
\hline 32 & \multirow{5}{*}{$\begin{array}{l}3500- \\
3750\end{array}$} & 81.82 & 1.56 & 30.4 & 26 & 1.0 & 10YR 4/3 brown & 5.5 & 0.00 & 0.00 & 0.29 & 0.00 & 1.12 & 0.00 & 0.24 & 54.89 & 0.00 & 0.00 & 56.54 \\
\hline 33 & & 84.64 & 2.82 & 39.6 & 34 & 1.0 & 10YR 4/3 brown & 5.5 & 0.00 & 0.00 & 0.70 & 0.00 & 1.47 & 0.00 & 0.01 & 66.76 & 3.52 & 0.00 & 72.46 \\
\hline 34 & & 87.36 & 2.72 & 39.3 & 35.5 & 1.0 & 10YR 4/3 brown & 5.5 & 0.00 & 0.00 & 0.52 & 0.00 & 1.95 & 0.00 & 0.10 & 60.38 & 0.00 & 0.00 & 62.95 \\
\hline 35 & & 89.64 & 2.28 & 32.1 & 28.5 & 1.0 & 10YR 4/3 brown & 5.5 & 0.00 & 0.00 & 0.04 & 0.00 & 0.73 & 0.00 & 0.21 & 44.59 & 0.00 & 0.00 & 45.57 \\
\hline 36 & & 92.48 & 2.84 & 42.7 & 40 & 1.0 & 10YR 4/3 brown & 5.5 & 0.00 & 0.00 & 0.07 & 0.00 & 1.56 & 0.00 & 0.13 & 71.99 & 0.00 & 0.00 & 73.75 \\
\hline 37 & \multirow{5}{*}{$\begin{array}{l}3750- \\
4000\end{array}$} & 94.96 & 2.48 & 38.3 & 33.5 & 1.0 & 10YR 4/3 brown & 5.5 & 0.00 & 0.00 & 0.36 & 0.00 & 1.24 & 0.00 & 0.00 & 81.40 & 0.00 & 0.00 & 83.00 \\
\hline 38 & & 97.40 & 2.44 & 34.7 & 30.5 & 1.0 & 10YR $5 / 3$ brown & 5.0 & 0.00 & 0.00 & 0.02 & 0.00 & 0.92 & 0.00 & 0.14 & 124.41 & 0.00 & 0.00 & 125.49 \\
\hline 39 & & 100.20 & 2.80 & 39.9 & 34.5 & 1.0 & $10 \mathrm{YR} 5 / 3$ brown & 5.5 & 0.00 & 0.00 & 0.05 & 0.00 & 1.44 & 0.00 & 0.13 & 269.76 & 4.50 & 0.00 & 275.88 \\
\hline 40 & & 102.80 & 2.60 & 36.7 & 31 & 1.0 & 10YR $5 / 3$ brown & 5.5 & 0.00 & 0.00 & 0.02 & 0.00 & 1.14 & 0.00 & 0.07 & 531.65 & 1.32 & 0.00 & 534.20 \\
\hline 41 & & 105.38 & 2.58 & 41.9 & 36 & 1.0 & 10YR 5/6 yellowish brown & 5.5 & 0.00 & 0.00 & 0.16 & 0.00 & 1.25 & 0.00 & 0.21 & 428.34 & 0.00 & 0.00 & 429.96 \\
\hline 42 & \multirow{6}{*}{$\begin{array}{l}4000- \\
4250\end{array}$} & 108.70 & 3.32 & 49.8 & 43.5 & 1.0 & $\begin{array}{l}10 \text { YR } 5 / 4 \text { dark yellowish } \\
\text { brown }\end{array}$ & 5.5 & 0.02 & 0.00 & 0.12 & 0.00 & 1.86 & 0.00 & 0.00 & 359.33 & 13.04 & 0.00 & 374.37 \\
\hline 43 & & 110.88 & 2.18 & 34.9 & 30.5 & 1.0 & 10YR 5/6 yellowish brown & 5.0 & 0.00 & 0.00 & 0.10 & 0.00 & 1.05 & 0.00 & 0.00 & 65.08 & 0.00 & 0.00 & 66.23 \\
\hline 44 & & 113.58 & 2.70 & 37.8 & 33.5 & 1.0 & 10YR 5/6 yellowish brown & 5.0 & 0.00 & 0.00 & 0.05 & 0.00 & 0.98 & 0.00 & 0.00 & 33.64 & 0.00 & 0.00 & 34.67 \\
\hline 45 & & 115.82 & 2.24 & 37.9 & 35 & 1.0 & $\begin{array}{l}\text { 10YR 5/4 dark yellowish } \\
\text { brown }\end{array}$ & 5.5 & 0.00 & 0.00 & 0.57 & 0.00 & 0.00 & 0.00 & 0.00 & 19.53 & 1.12 & 0.00 & 21.22 \\
\hline 46 & & 118.18 & 2.36 & 33.2 & 29.5 & 1.0 & $\begin{array}{l}10 Y R 5 / 4 \text { dark yellowish } \\
\text { brown }\end{array}$ & 5.5 & 0.00 & 0.00 & 0.00 & 0.00 & 1.36 & 0.00 & 0.00 & 16.85 & 0.00 & 0.00 & 18.21 \\
\hline 47 & & 120.94 & 2.76 & 38.5 & 34.5 & 1.0 & 10YR 5/6 yellowish brown & 5.5 & 0.00 & 0.00 & 0.07 & 0.00 & 0.77 & 0.00 & 0.00 & 12.30 & 0.00 & 0.00 & 13.14 \\
\hline 48 & \multirow{2}{*}{$\begin{array}{l}4250- \\
4500\end{array}$} & 123.74 & 2.80 & 46.2 & 40.5 & 1.0 & 10YR 5/6 yellowish brown & 5.5 & 0.00 & 0.00 & 0.00 & 0.00 & 0.32 & 0.00 & 0.00 & 14.45 & 0.00 & 0.00 & 14.77 \\
\hline 49 & & 126.68 & 2.94 & 44.3 & 40 & 1.0 & 10YR 5/6 yellowish brown & 5.0 & 0.00 & 0.00 & 0.00 & 0.00 & 1.81 & 0.00 & 0.00 & 15.86 & 0.00 & 0.00 & 17.67 \\
\hline
\end{tabular}


Appendix B. Summary excavation data and retained materials, Site 3 Mangrove Beach Headland Midden, Square A (cont.).

\begin{tabular}{|c|c|c|c|c|c|c|c|c|c|c|c|c|c|c|c|c|c|c|c|}
\hline 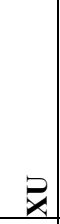 & है & 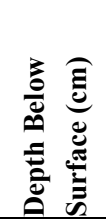 & 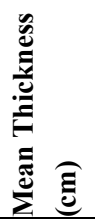 & 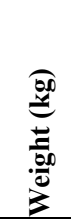 & 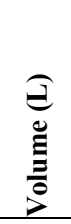 & 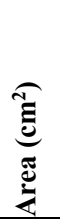 & 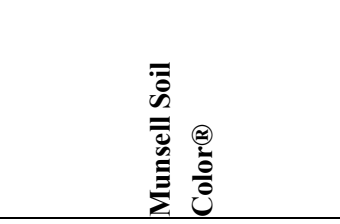 & $\frac{\pi}{2}$ & 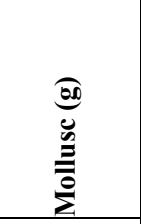 & $\begin{array}{l}\text { ब0, } \\
0 \\
0 \\
0 \\
0\end{array}$ & 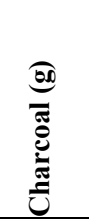 & 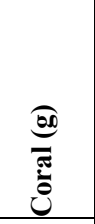 & 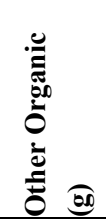 & 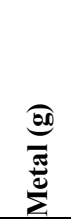 & 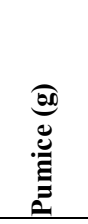 & 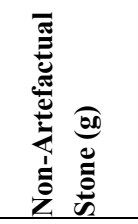 & 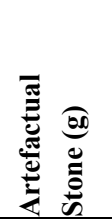 & 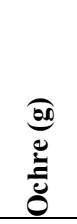 & 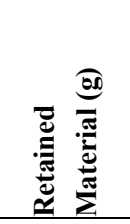 \\
\hline 50 & \multirow{3}{*}{$\begin{array}{c}4250- \\
4500\end{array}$} & 129.18 & 2.50 & 36.6 & 33 & 1.0 & 10YR $5 / 6$ yellowish brown & 5.5 & 0.01 & 0.00 & 0.00 & 0.00 & 1.14 & 0.00 & 0.00 & 11.29 & 0.00 & 0.00 & 12.44 \\
\hline 51 & & 131.74 & 2.56 & 40.6 & 36 & 1.0 & 10YR 5/6 yellowish brown & 5.0 & 0.00 & 0.00 & 0.00 & 0.00 & 1.67 & 0.00 & 0.00 & 12.75 & 0.00 & 0.00 & 14.42 \\
\hline 52 & & 134.20 & 2.46 & 38.5 & 33 & 1.0 & 10YR 5/6 yellowish brown & 5.0 & 0.00 & 0.00 & 0.00 & 0.00 & 0.97 & 0.00 & 0.00 & 7.99 & 0.00 & 0.00 & 8.96 \\
\hline 53 & \multirow{5}{*}{$\begin{array}{c}4500- \\
4750\end{array}$} & 136.82 & 2.62 & 38.8 & 34.5 & 1.0 & 10YR 6/6 brownish yellow & 5.5 & 0.00 & 0.00 & 0.00 & 0.00 & 0.70 & 0.00 & 0.00 & 8.78 & 0.00 & 0.00 & 9.48 \\
\hline 54 & & 139.38 & 2.56 & 38.0 & 32.5 & 1.0 & 10YR $6 / 6$ brownish yellow & 4.5 & 0.00 & 0.00 & 0.02 & 0.00 & 1.08 & 0.00 & 0.00 & 7.21 & 0.00 & 0.00 & 8.31 \\
\hline 55 & & 141.96 & 2.58 & 41.2 & 37.5 & 1.0 & 10YR 6/6 brownish yellow & 5.5 & 0.00 & 0.00 & 0.00 & 0.00 & 1.21 & 0.00 & 0.00 & 12.28 & 0.00 & 0.00 & 13.49 \\
\hline 56 & & 144.32 & 2.36 & 35.7 & 29 & 1.0 & 10YR 6/6 brownish yellow & 5.0 & 0.00 & 0.00 & 0.00 & 0.00 & 1.18 & 0.00 & 0.00 & 7.84 & 0.00 & 0.00 & 9.02 \\
\hline 57 & & 146.64 & 2.32 & 37.4 & 32.5 & 1.0 & 10YR 6/6 brownish yellow & 5.5 & 0.00 & 0.00 & 0.00 & 0.00 & 1.04 & 0.00 & 0.00 & 9.29 & 0.00 & 0.00 & 10.33 \\
\hline 58 & \multirow{3}{*}{$\begin{array}{c}4750- \\
5000 \\
\end{array}$} & 149.26 & 2.62 & 37.4 & 32 & 1.0 & 10YR 6/6 brownish yellow & 5.0 & 0.00 & 0.00 & 0.00 & 0.00 & 1.51 & 0.00 & 0.00 & 13.43 & 0.00 & 0.00 & 14.94 \\
\hline 59 & & 151.74 & 2.48 & 36.8 & 34.5 & 1.0 & 10YR 6/6 brownish yellow & 5.5 & 0.00 & 0.00 & 0.00 & 0.00 & 1.07 & 0.00 & 0.00 & 11.12 & 0.00 & 0.00 & 12.19 \\
\hline & & & & & & & & & 20100.51 & 15.95 & 65.35 & 46.66 & 259.23 & 3.47 & 81.39 & 15718.55 & 198.32 & 3.10 & 36492.53 \\
\hline
\end{tabular}


Appendix C. Magnetic susceptibility data, Site 3 Mangrove Beach Headland Midden, Square A.

\begin{tabular}{|c|c|c|c|c|c|c|}
\hline $\mathbf{X U}$ & $\begin{array}{c}\text { Depth } \\
(\mathrm{cm})\end{array}$ & $\begin{array}{c}\text { Mass } \\
(\mathrm{g}) \\
\end{array}$ & $\begin{array}{c}\text { Mass } \\
\text { Susceptibility } \\
\left(\mathrm{m}^{\wedge} \mathbf{3} / \mathbf{k g}\right) \\
\end{array}$ & $\begin{array}{c}\text { Volume } \\
\text { Susceptibility } \\
\text { (SI) } \\
\end{array}$ & $\begin{array}{c}\text { Frequency } \\
\text { Dependence } \\
(\%) \\
\end{array}$ & $\begin{array}{c}\text { XIf-Xhf } \\
\text { (X 10-7 m3/kg) }\end{array}$ \\
\hline 1 & 2.02 & 6.97 & $6.35 \mathrm{E}-08$ & 8.39E-06 & 5.1 & $1.95 \mathrm{E}-06$ \\
\hline 2 & 5.12 & 7.34 & $6.56 \mathrm{E}-08$ & $9.12 \mathrm{E}-06$ & 6.6 & $2.75 \mathrm{E}-06$ \\
\hline 3 & 7.54 & 7.06 & $6.47 \mathrm{E}-08$ & $8.65 \mathrm{E}-06$ & 10.5 & $4.12 \mathrm{E}-06$ \\
\hline 4 & 9.66 & 7.09 & $5.86 \mathrm{E}-08$ & 7.87E-06 & 8.3 & $2.94 \mathrm{E}-06$ \\
\hline 5 & 12.54 & 6.63 & $5.86 \mathrm{E}-08$ & $7.36 \mathrm{E}-06$ & 12.0 & $3.94 \mathrm{E}-06$ \\
\hline 6 & 14.96 & 7.17 & 5.75E-08 & 7.81E-06 & 11.2 & $3.94 \mathrm{E}-06$ \\
\hline 7 & 17.52 & 6.87 & $5.16 \mathrm{E}-08$ & $6.72 \mathrm{E}-06$ & 5.7 & $1.67 \mathrm{E}-06$ \\
\hline 8 & 19.98 & 7.67 & 5.03E-08 & $7.30 \mathrm{E}-06$ & 8.2 & $2.66 \mathrm{E}-06$ \\
\hline 9 & 21.98 & 7.29 & $5.57 \mathrm{E}-08$ & 7.69E-06 & 8.7 & $3.00 \mathrm{E}-06$ \\
\hline 10 & 24.26 & 7.23 & $4.81 \mathrm{E}-08$ & $6.59 \mathrm{E}-06$ & 9.2 & $2.66 \mathrm{E}-06$ \\
\hline 11 & 26.86 & 7.42 & $4.96 \mathrm{E}-08$ & $6.97 \mathrm{E}-06$ & 7.5 & $2.31 \mathrm{E}-06$ \\
\hline 12 & 29.98 & 7.66 & $3.78 \mathrm{E}-08$ & 5.49E-06 & 5.6 & $1.29 \mathrm{E}-06$ \\
\hline 13 & 32.32 & 7.21 & 3.69E-08 & 5.04E-06 & 6.5 & $1.36 \mathrm{E}-06$ \\
\hline 14 & 34.94 & 7.67 & $3.20 \mathrm{E}-08$ & 4.66E-06 & 12.2 & $2.31 \mathrm{E}-06$ \\
\hline 15 & 37.8 & 7.42 & $3.08 \mathrm{E}-08$ & 4.33E-06 & 13.6 & $2.34 \mathrm{E}-06$ \\
\hline 16 & 40.46 & 7.51 & $3.22 \mathrm{E}-08$ & 4.59E-06 & 10.9 & $2.02 \mathrm{E}-06$ \\
\hline 17 & 43.1 & 7.73 & $3.04 \mathrm{E}-08$ & $4.46 \mathrm{E}-06$ & 14.7 & $2.63 \mathrm{E}-06$ \\
\hline 18 & 45.64 & 7.31 & $2.85 \mathrm{E}-08$ & $3.94 \mathrm{E}-06$ & 10.9 & $1.65 \mathrm{E}-06$ \\
\hline 19 & 48.1 & 7.33 & $2.98 \mathrm{E}-08$ & 4.13E-06 & 14.4 & $2.33 \mathrm{E}-06$ \\
\hline 20 & 54.3 & 7.49 & $3.05 \mathrm{E}-08$ & 4.33E-06 & 13.5 & $2.32 \mathrm{E}-06$ \\
\hline 21 & 56.88 & 7.47 & $2.97 \mathrm{E}-08$ & $4.20 \mathrm{E}-06$ & 13.9 & $2.30 \mathrm{E}-06$ \\
\hline 22 & 59.22 & 7.65 & $3.17 \mathrm{E}-08$ & $4.59 \mathrm{E}-06$ & 9.3 & $1.72 \mathrm{E}-06$ \\
\hline 23 & 61.08 & 7.61 & $3.81 \mathrm{E}-08$ & $5.49 \mathrm{E}-06$ & 15.7 & $3.64 \mathrm{E}-06$ \\
\hline 24 & 63.84 & 7.44 & 4.33E-08 & $6.10 \mathrm{E}-06$ & 3.2 & $8.35 \mathrm{E}-07$ \\
\hline 25 & 66.1 & 7.48 & 4.60E-08 & $6.52 \mathrm{E}-06$ & 9.3 & $2.65 \mathrm{E}-06$ \\
\hline 26 & 68.76 & 7.37 & $5.65 \mathrm{E}-08$ & $7.88 \mathrm{E}-06$ & 12.1 & $4.29 \mathrm{E}-06$ \\
\hline 27 & 70.32 & 7.68 & 4.97E-08 & 7.23E-06 & 13.4 & $4.29 \mathrm{E}-06$ \\
\hline 28 & 72.42 & 7.69 & 5.67E-08 & $8.26 \mathrm{E}-06$ & 10.6 & $3.96 \mathrm{E}-06$ \\
\hline 29 & 75.2 & 7.64 & $3.84 \mathrm{E}-08$ & $5.55 \mathrm{E}-06$ & 5.5 & $1.29 \mathrm{E}-06$ \\
\hline 30 & 77.98 & 7.76 & 4.65E-08 & $6.84 \mathrm{E}-06$ & 5.4 & $1.64 \mathrm{E}-06$ \\
\hline 31 & 80.26 & 7.72 & $5.30 \mathrm{E}-08$ & $7.75 \mathrm{E}-06$ & 9.5 & $3.31 \mathrm{E}-06$ \\
\hline 32 & 81.82 & 7.87 & $3.12 \mathrm{E}-08$ & $4.65 \mathrm{E}-06$ & 6.9 & $1.31 \mathrm{E}-06$ \\
\hline 33 & 84.64 & 7.82 & $3.49 \mathrm{E}-08$ & 5.17E-06 & 10.7 & $2.30 \mathrm{E}-06$ \\
\hline 34 & 87.36 & 7.78 & $3.38 \mathrm{E}-08$ & $4.98 \mathrm{E}-06$ & 14.6 & $3.00 \mathrm{E}-06$ \\
\hline 35 & 89.64 & 7.73 & 3.04E-08 & $4.45 \mathrm{E}-06$ & 16.5 & $2.94 \mathrm{E}-06$ \\
\hline 36 & 92.48 & 7.62 & $2.60 \mathrm{E}-08$ & $3.75 \mathrm{E}-06$ & 16.0 & $2.28 \mathrm{E}-06$ \\
\hline 37 & 94.96 & 7.84 & $2.52 \mathrm{E}-08$ & $3.75 \mathrm{E}-06$ & 18.7 & $2.66 \mathrm{E}-06$ \\
\hline 38 & 97.4 & 7.93 & $2.16 \mathrm{E}-08$ & $3.24 \mathrm{E}-06$ & 18.0 & $2.38 \mathrm{E}-06$ \\
\hline 39 & 100.2 & 7.86 & $2.26 \mathrm{E}-08$ & $3.36 \mathrm{E}-06$ & 16.0 & $1.95 \mathrm{E}-06$ \\
\hline 40 & 102.8 & 7.84 & $1.74 \mathrm{E}-08$ & $2.59 \mathrm{E}-06$ & 16.2 & $1.35 \mathrm{E}-06$ \\
\hline 41 & 105.38 & 7.84 & $1.79 \mathrm{E}-08$ & $2.66 \mathrm{E}-06$ & 18.0 & $2.98 \mathrm{E}-06$ \\
\hline 42 & 108.7 & 7.88 & $1.39 \mathrm{E}-08$ & $2.07 \mathrm{E}-06$ & 11.8 & $6.60 \mathrm{E}-07$ \\
\hline 43 & 110.88 & 7.71 & $1.29 \mathrm{E}-08$ & $1.88 \mathrm{E}-06$ & 13.7 & $6.35 \mathrm{E}-07$ \\
\hline 44 & 113.58 & 7.38 & $1.67 \mathrm{E}-08$ & 2.33E-06 & 18.0 & $2.97 \mathrm{E}-06$ \\
\hline 45 & 115.82 & 7.74 & $2.16 \mathrm{E}-08$ & $3.17 \mathrm{E}-06$ & 16.0 & $6.64 \mathrm{E}-06$ \\
\hline 46 & 118.18 & 7.64 & $1.48 \mathrm{E}-08$ & $2.14 \mathrm{E}-06$ & 0.0 & $3.01 \mathrm{E}-06$ \\
\hline 47 & 120.94 & 7.75 & $1.37 \mathrm{E}-08$ & $2.01 \mathrm{E}-06$ & 0.0 & $2.30 \mathrm{E}-06$ \\
\hline 48 & 123.74 & 7.38 & $1.76 \mathrm{E}-08$ & $2.46 \mathrm{E}-06$ & 0.0 & $5.32 \mathrm{E}-06$ \\
\hline 49 & 126.68 & 7.88 & $1.05 \mathrm{E}-08$ & $1.56 \mathrm{E}-06$ & 0.0 & $1.01 \mathrm{E}-06$ \\
\hline 50 & 129.18 & 7.81 & $1.66 \mathrm{E}-08$ & $2.46 \mathrm{E}-06$ & 0.0 & $6.30 \mathrm{E}-06$ \\
\hline
\end{tabular}


Appendix C. Magnetic susceptibility data, Site 3 Mangrove Beach Headland Midden, Square A (cont.).

\begin{tabular}{|c|r|r|r|r|r|c|}
\hline $\mathbf{X U}$ & $\begin{array}{r}\text { Depth } \\
\mathbf{( c m )}\end{array}$ & $\begin{array}{r}\text { Mass } \\
\mathbf{( g )}\end{array}$ & $\begin{array}{r}\text { Mass } \\
\text { Susceptibility } \\
(\mathbf{m} \text { (3/kg) }\end{array}$ & $\begin{array}{r}\text { Volume } \\
\text { Susceptibility } \\
\mathbf{( S I )}\end{array}$ & $\begin{array}{r}\text { Frequency } \\
\text { Dependence } \\
\mathbf{( \% )}\end{array}$ & $\begin{array}{r}\text { XIf-Xhf } \\
\mathbf{( X ~ 1 0 - 7 ~ m 3 / k g )}\end{array}$ \\
\hline 51 & 131.74 & 7.36 & $1.11 \mathrm{E}-08$ & $1.55 \mathrm{E}-06$ & 0.0 & - \\
\hline 52 & 134.2 & 7.54 & $9.99 \mathrm{E}-09$ & $1.43 \mathrm{E}-06$ & 0.0 & - \\
\hline 53 & 136.82 & 7.82 & $1.31 \mathrm{E}-08$ & $1.94 \mathrm{E}-06$ & 0.0 & - \\
\hline 54 & 139.38 & 7.7 & $9.75 \mathrm{E}-09$ & $1.42 \mathrm{E}-06$ & 0.0 & - \\
\hline 55 & 141.96 & 7.48 & $8.67 \mathrm{E}-09$ & $1.23 \mathrm{E}-06$ & 0.0 & $1.94 \mathrm{E}-06$ \\
\hline 56 & 144.32 & 7.5 & $1.32 \mathrm{E}-08$ & $1.88 \mathrm{E}-06$ & 0.0 & - \\
\hline 57 & 146.64 & 7.26 & $8.97 \mathrm{E}-09$ & $1.23 \mathrm{E}-06$ & 0.0 & - \\
\hline 58 & 149.26 & 7.65 & $1.12 \mathrm{E}-08$ & $1.62 \mathrm{E}-06$ & 0.0 & $2.67 \mathrm{E}-06$ \\
\hline 59 & 151.74 & 7.53 & $1.32 \mathrm{E}-08$ & $1.88 \mathrm{E}-06$ & 0.0 & $3.97 \mathrm{E}-06$ \\
\hline
\end{tabular}


Appendix D. Percentage values for identified pollen-spore types and micro-charcoal concentration, Site 3 Mangrove Beach Headland Midden, Square A.

\begin{tabular}{|c|c|c|c|c|c|c|c|c|c|c|c|c|c|c|c|c|c|c|c|c|c|c|c|c|c|c|c|c|c|c|c|}
\hline$\vec{x}$ & 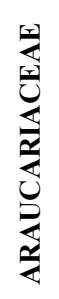 & Е & 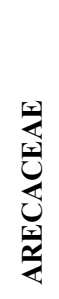 & 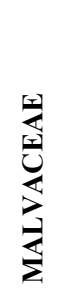 & 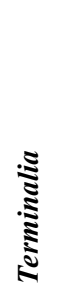 & 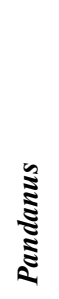 & 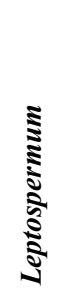 & 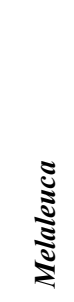 & 壳 & 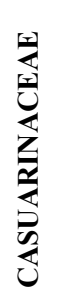 & 莣 & $\begin{array}{l}\mathbb{Z} \\
\mathbb{E} \\
\mathbb{E}\end{array}$ & 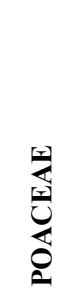 & 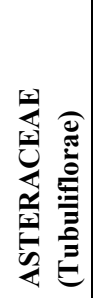 & 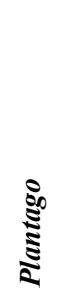 & 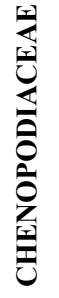 & 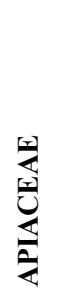 & 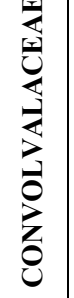 & 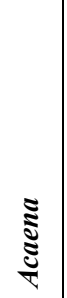 & ڤั: & 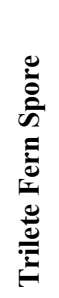 & 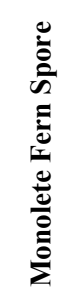 & 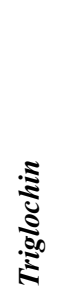 & 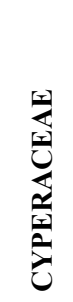 & 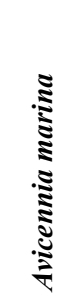 & 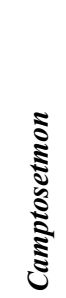 & 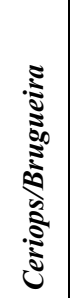 & 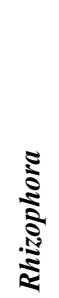 & $\begin{array}{l}\Xi \\
\overline{\bar{D}} \\
\bar{\Xi} \\
\overline{\overline{0}}\end{array}$ & 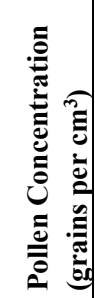 & 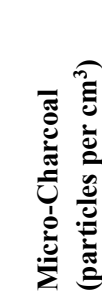 \\
\hline 1 & 0 & 0 & 0.9 & 0 & 0 & 0 & 0 & 31.8 & 16.5 & 5.4 & 0.6 & 5.4 & 12.8 & 11.1 & 0 & 0 & 9.1 & 0 & 0 & 0 & 0.3 & 0.6 & 0 & 1.4 & 2 & 0.6 & 0.3 & 1.4 & 352 & 2429 & 9832 \\
\hline 2 & 0 & 0.4 & 3.2 & 0.4 & 0.8 & 1.2 & 0 & 21.4 & 12.7 & 3.6 & 1.2 & 4 & 17.5 & 7.5 & 0 & 0 & 7.9 & 0.4 & 0.4 & 0.4 & 1.2 & 0.4 & 0.4 & 4.4 & 7.5 & 0 & 1.2 & 2 & 252 & 519 & 16722 \\
\hline 3 & 0 & 0 & 3.7 & 0 & 0 & 0 & 0 & 7.4 & 0 & 0 & 0 & 3.7 & 44.4 & 0 & 3.7 & 0 & 3.7 & 0 & 0 & 3.7 & 0 & \begin{tabular}{|l|}
11.1 \\
\end{tabular} & 0 & 14.8 & 0 & 0 & 0 & 3.7 & 27 & 143 & 14096 \\
\hline 4 & 0 & 0 & 0 & 0 & 0 & 0 & 0 & 11.4 & 4.5 & 2.3 & 0 & 0 & $\begin{array}{l}72.7 \\
\end{array}$ & 0 & 0 & 0 & 0 & \begin{tabular}{l|l}
0 \\
\end{tabular} & 0 & 0 & 0 & 4.5 & 0 & 4.5 & 0 & 0 & 0 & 0 & 44 & 144 & 10672 \\
\hline 5 & 0 & 3.3 & 0 & 0 & 0 & 0 & 0 & 3.3 & 6.7 & 0 & 3.3 & 3.3 & 56.7 & 0 & 0 & 0 & 0 & 0 & 0 & 6.7 & 0 & 0 & 0 & 3.3 & 13.3 & 0 & 0 & 0 & 30 & 180 & 13564 \\
\hline 6 & 0 & 0 & 3.3 & 0 & 0 & 0 & 0 & 5.4 & 3.3 & 3.3 & 4.3 & 0 & 66.3 & 0 & 1.1 & 1.1 & 0 & 0 & 0 & 0 & 1.1 & 2.2 & 0 & 6.5 & 1.1 & 0 & 1.1 & 0 & 92 & 249 & 15054 \\
\hline 7 & 6.4 & 0 & 0 & 0 & 0 & 1.3 & 1.3 & 1.3 & 5.1 & 3.8 & 3.8 & 1.3 & 64.1 & 1.3 & 0 & 0 & 0 & 0 & 0 & 0 & 0 & 2.6 & 0 & 7.7 & 0 & 0 & 0 & 0 & 78 & 142 & 16797 \\
\hline 8 & 0 & 0 & 0 & 0 & 0 & 0 & 0 & 0 & 0 & 0 & 0 & 0 & 0 & 0 & 0 & 0 & 0 & 0 & 0 & 0 & 0 & 0 & 0 & 0 & 0 & 0 & 0 & 0 & 0 & 0 & 34125 \\
\hline 9 & 0 & 0 & 0 & 0 & 0 & 0 & 0 & 0 & 0 & 0 & 0 & 0 & 0 & 0 & 0 & 0 & 0 & 0 & 0 & 0 & 0 & 0 & 0 & 0 & 0 & 0 & 0 & 0 & 0 & 0 & 12266 \\
\hline 10 & 0 & 0 & 0 & 0 & 0 & 0 & 0 & 0 & 0 & 0 & 0 & 0 & 0 & 0 & 0 & 0 & 0 & 0 & 0 & 0 & 0 & 0 & 0 & 0 & 0 & 0 & 0 & 0 & 0 & 0 & 42656 \\
\hline 11 & 0 & 0 & 0 & 0 & 0 & 0 & 0 & 0 & 0 & 0 & 0 & 0 & 0 & 0 & 0 & 0 & 0 & 0 & 0 & 0 & 0 & 0 & 0 & 0 & 0 & 0 & 0 & 0 & 0 & 0 & 0 \\
\hline 12 & 0 & 0 & 0 & 0 & 0 & 0 & 0 & 0 & 0 & 0 & 0 & 0 & 0 & 0 & 0 & 0 & 0 & 0 & 0 & 0 & 0 & 0 & 0 & 0 & 0 & 0 & 0 & 0 & 0 & 0 & 0 \\
\hline 13 & 0 & 0 & 0 & 0 & 0 & 0 & 0 & 0 & 0 & 0 & 0 & 0 & 0 & 0 & 0 & 0 & 0 & 0 & 0 & 0 & 0 & 0 & 0 & 0 & 0 & 0 & 0 & 0 & 0 & 0 & 26570 \\
\hline 14 & 0 & 0 & 0 & 0 & 0 & 0 & 0 & 0 & 0 & 0 & 0 & 0 & 0 & 0 & 0 & 0 & 0 & 0 & 0 & 0 & 0 & 0 & 0 & 0 & 0 & 0 & 0 & 0 & 0 & 0 & 13872 \\
\hline 15 & 0 & 0 & 0 & 0 & 0 & 0 & 0 & 0 & 0 & 0 & 0 & 0 & 0 & 0 & 0 & 0 & 0 & 0 & 0 & 0 & 0 & 0 & 0 & 0 & 0 & 0 & 0 & 0 & 0 & 0 & 105427 \\
\hline 16 & 0 & 0 & 0 & 0 & 0 & 0 & 0 & 0 & 0 & 0 & 0 & 0 & 0 & 0 & 0 & 0 & 0 & 0 & 0 & 0 & 0 & 0 & 0 & 0 & 0 & 0 & 0 & 0 & 0 & 0 & 115138 \\
\hline 17 & 0 & 0 & 0 & 0 & 0 & 0 & 0 & 0 & 0 & 0 & 0 & 0 & 0 & 0 & 0 & 0 & 0 & 0 & 0 & 0 & 0 & 0 & 0 & 0 & 0 & 0 & 0 & 0 & 0 & 0 & 81845 \\
\hline 18 & 0 & 0 & 0 & 0 & 0 & 0 & 0 & 0 & 0 & 0 & 0 & 0 & 0 & 0 & 0 & 0 & 0 & 0 & 0 & 0 & 0 & 0 & 0 & 0 & 0 & 0 & 0 & 0 & 0 & 0 & \\
\hline 19 & 0 & 0 & 0 & 0 & 0 & 0 & 0 & 0 & 0 & 0 & 0 & 0 & 0 & 0 & 0 & 0 & 0 & 0 & 0 & 0 & 0 & 0 & 0 & 0 & 0 & 0 & 0 & 0 & 0 & 0 & 27744 \\
\hline 20 & 0 & 0 & 0 & 0 & 0 & 0 & 0 & 0 & 0 & 0 & 0 & 0 & 0 & 0 & 0 & 0 & 0 & 0 & 0 & 0 & 0 & 0 & 0 & 0 & 0 & 0 & 0 & 0 & 0 & 0 & 65198 \\
\hline 21 & 0 & 0 & 0 & 0 & 0 & 0 & 0 & 0 & 0 & 0 & 0 & 0 & 0 & 0 & 0 & 0 & 0 & 0 & 0 & 0 & 0 & 0 & 0 & 0 & 0 & 0 & 0 & 0 & 0 & 0 & 235824 \\
\hline 22 & 0 & 0 & 0 & 0 & 0 & 0 & 0 & 0 & 0 & 0 & 0 & 0 & 0 & 0 & 0 & 0 & 0 & 0 & 0 & 0 & 0 & 0 & 0 & 0 & 0 & 0 & 0 & 0 & 0 & 0 & 58262 \\
\hline 23 & 0 & 0 & 0 & 0 & 0 & 0 & 0 & 0 & 0 & 0 & 0 & 0 & 0 & 0 & 0 & 0 & 0 & 0 & 0 & 0 & 0 & 0 & 0 & 0 & 0 & 0 & 0 & 0 & 0 & 0 & 439049 \\
\hline 24 & 0 & 0 & 0 & 0 & 0 & 0 & 0 & 0 & 0 & 0 & 0 & 0 & 0 & 0 & 0 & 0 & 0 & 0 & 0 & 0 & 0 & 0 & 0 & 0 & 0 & 0 & 0 & 0 & 0 & 0 & 312120 \\
\hline 25 & 0 & 0 & 0 & 0 & 0 & 0 & 0 & 0 & 0 & 0 & 0 & 0 & 0 & 0 & 0 & 0 & 0 & 0 & 0 & 0 & 0 & 0 & 0 & 0 & 0 & 0 & 0 & 0 & 0 & 0 & 24970 \\
\hline 26 & 0 & 0 & 0 & 0 & 0 & 0 & 0 & 0 & 0 & 0 & 0 & 0 & 0 & 0 & 0 & 0 & 0 & 0 & 0 & 0 & 0 & 0 & 0 & 0 & 0 & 0 & 0 & 0 & 0 & 0 & 499392 \\
\hline 27 & 0 & 0 & 0 & 0 & 0 & 0 & 0 & 0 & 0 & 0 & 0 & 0 & 0 & 0 & 0 & 0 & 0 & 0 & 0 & 0 & 0 & 0 & 0 & 0 & 0 & 0 & 0 & 0 & 0 & 0 & 218484 \\
\hline 28 & 0 & 0 & 0 & 0 & 0 & 0 & 0 & 0 & 0 & 0 & 0 & 0 & 0 & 0 & 0 & 0 & 0 & 0 & 0 & 0 & 0 & 0 & 0 & 0 & 0 & 0 & 0 & 0 & 0 & 0 & 94330 \\
\hline 29 & 0 & 0 & 0 & 0 & 0 & 0 & 0 & 0 & 0 & 0 & 0 & 0 & 0 & 0 & 0 & 0 & 0 & \begin{tabular}{l|l}
0 \\
\end{tabular} & 0 & 0 & 0 & 0 & 0 & 0 & 0 & 0 & 0 & 0 & 0 & 0 & 136738 \\
\hline
\end{tabular}


Appendix D. Percentage values for identified pollen-spore types and micro-charcoal concentration, Site 3 Mangrove Beach Headland Midden, Square A (cont.).

\begin{tabular}{|c|c|c|c|c|c|c|c|c|c|c|c|c|c|c|c|c|c|c|c|c|c|c|c|c|c|c|c|c|c|c|c|}
\hline$\vec{x}$ & 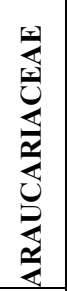 & Е & 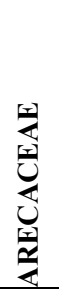 & 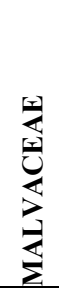 & 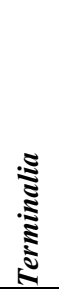 & 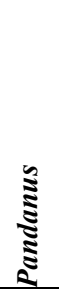 & 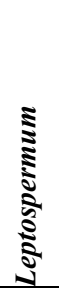 & 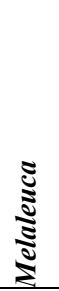 & 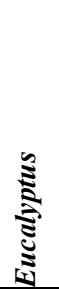 & 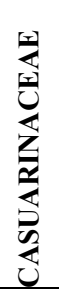 & 胥 & $\begin{array}{l}\mathbb{\Xi} \\
\stackrel{\Xi}{\Xi}\end{array}$ & 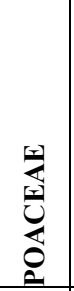 & 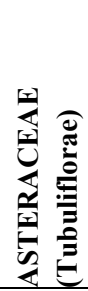 & 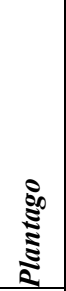 & 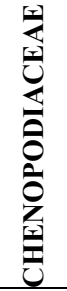 & 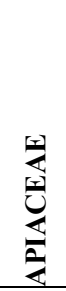 & 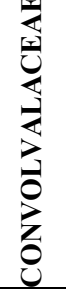 & 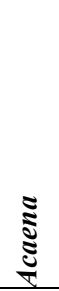 & 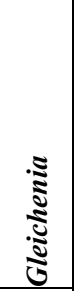 & 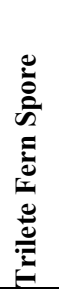 & 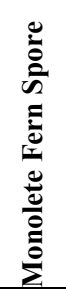 & 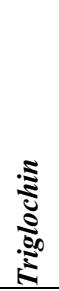 & 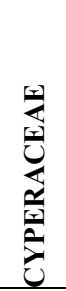 & 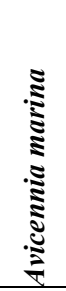 & 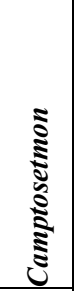 & 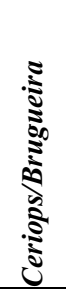 & 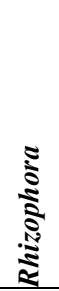 & 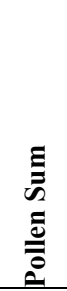 & 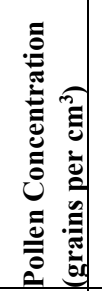 & 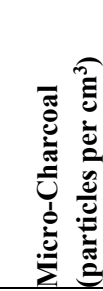 \\
\hline 30 & 0 & 0 & 0 & 0 & 0 & 0 & 0 & 0 & 0 & 0 & 0 & 0 & 0 & 0 & 0 & 0 & 0 & 0 & 0 & 0 & 0 & 0 & 0 & 0 & 0 & 0 & 0 & 0 & 0 & 0 & 136738 \\
\hline 31 & 0 & 0 & 0 & 0 & 0 & 0 & 0 & 0 & 0 & 0 & 0 & 0 & 0 & 0 & 0 & 0 & 0 & 0 & 0 & 0 & 0 & 0 & 0 & 0 & 0 & 0 & 0 & 0 & 0 & 0 & 3588 \\
\hline 32 & 0 & 0 & 0 & 0 & 0 & 0 & 0 & 0 & 0 & 0 & 0 & 0 & 0 & 0 & 0 & 0 & 0 & 0 & 0 & 0 & 0 & 0 & 0 & 0 & 0 & 0 & 0 & 0 & 0 & 0 & 105601 \\
\hline 33 & 0 & 0 & 0 & 0 & 0 & 0 & 0 & 0 & 0 & 0 & 0 & 0 & 0 & 0 & 0 & 0 & 0 & 0 & 0 & 0 & 0 & 0 & 0 & 0 & 0 & 0 & 0 & 0 & 0 & 0 & 89891 \\
\hline 34 & 0 & 0 & 0 & 0 & 0 & 0 & 0 & 0 & 0 & 0 & 0 & 0 & 0 & 0 & 0 & 0 & 0 & 0 & 0 & 0 & 0 & 0 & 0 & 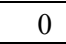 & 0 & 0 & 0 & 0 & 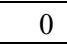 & 0 & 116524 \\
\hline 35 & 0 & 0 & 0 & 0 & 0 & 0 & 0 & 0 & 0 & 0 & 0 & 0 & 0 & 0 & 0 & 0 & 0 & 0 & 0 & 0 & 0 & 0 & 0 & ( & 0 & 0 & 0 & 0 & I & 0 & 41616 \\
\hline 36 & 0 & 0 & 0 & 0 & 0 & 0 & 0 & 0 & 0 & 0 & 0 & 0 & 0 & 0 & 0 & 0 & 0 & 0 & 0 & 0 & 0 & 0 & 0 & 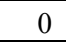 & 0 & 0 & 0 & 0 & 0 & 0 & 13872 \\
\hline 37 & 0 & 0 & 0 & 0 & 0 & 0 & 0 & 0 & 0 & 0 & 0 & 0 & 0 & 0 & 0 & 0 & 0 & 0 & 0 & 0 & 0 & 0 & 0 & 0 & 0 & 0 & 0 & 0 & 0 & 0 & 20808 \\
\hline 38 & 0 & 0 & 0 & 0 & 0 & 0 & 0 & 0 & 0 & 0 & 0 & 0 & 0 & 0 & 0 & 0 & 0 & 0 & 0 & 0 & 0 & 0 & 0 & 0 & 0 & 0 & 0 & 0 & 0 & 0 & 10404 \\
\hline 39 & 0 & 0 & 0 & 0 & 0 & 0 & 0 & 0 & 0 & 0 & 0 & 0 & 0 & 0 & 0 & 0 & 0 & 0 & 0 & 0 & 0 & 0 & 0 & 0 & 0 & 0 & 0 & 0 & 0 & 0 & 208080 \\
\hline 40 & 0 & 0 & 0 & 0 & 0 & 0 & 0 & 0 & 0 & 0 & 0 & 0 & 0 & 0 & 0 & 0 & 0 & 0 & 0 & 0 & 0 & 0 & 0 & 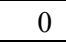 & 0 & 0 & 0 & 0 & 0 & 0 & 41616 \\
\hline 41 & 0 & 0 & 0 & 0 & 0 & 0 & 0 & 0 & 0 & 0 & 0 & 0 & 0 & 0 & 0 & 0 & 0 & 0 & 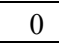 & 0 & 0 & 0 & 0 & 0 & 0 & 0 & 0 & 0 & ( & 0 & 8989 \\
\hline 42 & 0 & 0 & 0 & 0 & 0 & 0 & 0 & 0 & 0 & 0 & 0 & 0 & 0 & 0 & 0 & 0 & 0 & 0 & 0 & 0 & 0 & 0 & 0 & 0 & 0 & ( & 0 & 0 & 0 & 0 & 11890 \\
\hline 43 & 0 & 0 & 0 & 0 & 0 & 0 & 0 & 0 & 0 & 0 & 0 & 0 & 0 & 0 & 0 & 0 & 0 & 0 & 0 & 0 & 0 & 0 & 0 & 0 & 0 & 0 & 0 & 0 & 0 & 0 & 4162 \\
\hline 44 & 0 & 0 & 0 & 0 & 0 & 0 & 0 & 0 & 0 & 0 & 0 & 0 & 0 & 0 & 0 & 0 & 0 & 0 & 0 & 0 & 0 & 0 & 0 & -0 & 0 & 0 & 0 & 0 & 0 & 0 & 2081 \\
\hline 45 & 0 & 0 & 0 & 0 & 0 & 0 & 0 & 0 & 0 & 0 & 0 & 0 & 0 & 0 & 0 & 0 & 0 & 0 & 0 & 0 & 0 & 0 & 0 & 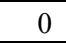 & 0 & 0 & 0 & 0 & 0 & 0 & 4162 \\
\hline 46 & 0 & 0 & 0 & 0 & 0 & 0 & 0 & 0 & 0 & 0 & 0 & 0 & 0 & 0 & 0 & 0 & 0 & 0 & . & 0 & 0 & 0 & 0 & 0 & 0 & 0 & 0 & 0 & 0 & 0 & 4162 \\
\hline 47 & 0 & 0 & 0 & 0 & 0 & 0 & 0 & 0 & 0 & 0 & 0 & 0 & 0 & 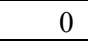 & 0 & 0 & 0 & 0 & 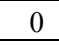 & 0 & 0 & 0 & 0 & 0 & 0 & 0 & 0 & 0 & 0 & 0 & 4162 \\
\hline 48 & 0 & 0 & 0 & 0 & 0 & 0 & 0 & 0 & 0 & 0 & 0 & 0 & 0 & 0 & 0 & 0 & 0 & 0 & 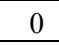 & 0 & 0 & 0 & 0 & 0 & 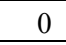 & ( & 0 & 0 & 0 & 0 & 0 \\
\hline 49 & 0 & 0 & 0 & 0 & 0 & 0 & 0 & 0 & 0 & 0 & 0 & 0 & 0 & 0 & 0 & 0 & 0 & 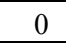 & 0 & 0 & 0 & 0 & 0 & 0 & 0 & 7 & 0 & 0 & 0 & 0 & 8323 \\
\hline 50 & 0 & 0 & 0 & 0 & 0 & 0 & 0 & 0 & 0 & 0 & 0 & 0 & 0 & 0 & 0 & 0 & 0 & 0 & 0 & 0 & 0 & 0 & 0 & 0 & 0 & 0 & 0 & 0 & 0 & 0 & 13317 \\
\hline 51 & 0 & 0 & 0 & 0 & 0 & 0 & 0 & 0 & 0 & 0 & 0 & 0 & 0 & 0 & 0 & 0 & 0 & 0 & 0 & 0 & 0 & 0 & 0 & 0 & 0 & 0 & 0 & 0 & 0 & 0 & 0 \\
\hline 52 & 0 & 0 & 0 & 0 & 0 & 0 & 0 & 0 & 0 & 0 & 0 & 0 & 0 & 0 & 0 & 0 & 0 & 0 & 0 & 0 & 0 & 0 & 0 & 0 & 0 & 0 & 0 & 0 & 0 & 0 & 0 \\
\hline 53 & 0 & 0 & 0 & 0 & 0 & 0 & 0 & 0 & 0 & 0 & 0 & 0 & 0 & 0 & 0 & 0 & 0 & 0 & 0 & 0 & 0 & 0 & 0 & 0 & 0 & 0 & 0 & 0 & 0 & 0 & 0 \\
\hline 54 & 0 & 0 & 0 & 0 & 0 & 0 & 0 & 0 & 0 & 0 & 0 & 0 & 0 & 0 & 0 & 0 & 0 & 0 & 0 & 0 & 0 & 0 & 0 & 0 & 0 & 0 & 0 & 0 & 0 & 0 & 0 \\
\hline 55 & 0 & 0 & 0 & 0 & 0 & 0 & 0 & 0 & 0 & 0 & 0 & 0 & 0 & 0 & 0 & 0 & 0 & 0 & 0 & 0 & 0 & 0 & 0 & 0 & 0 & 0 & 0 & 0 & 0 & 0 & 2732 \\
\hline 56 & 0 & 0 & 0 & 0 & 0 & 0 & 0 & 0 & 0 & 0 & 0 & 0 & 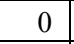 & 0 & 0 & 0 & 0 & 0 & 0 & 0 & 0 & 0 & 0 & 0 & 0 & 0 & 0 & 0 & 0 & 0 & 1355 \\
\hline 57 & 0 & 0 & 0 & 0 & 0 & 0 & 0 & 0 & 0 & 0 & 0 & 0 & 0 & 0 & 0 & 0 & 0 & 0 & 0 & 0 & 0 & 0 & 0 & 0 & 0 & 0 & 0 & 0 & 0 & 0 & 0 \\
\hline 58 & 0 & 0 & 0 & 0 & 0 & 0 & 0 & 0 & 0 & 0 & 0 & 0 & 0 & 0 & 0 & 0 & 0 & 0 & 0 & 0 & 0 & 0 & 0 & 0 & 0 & 0 & 0 & 0 & 0 & 0 & 2270 \\
\hline 59 & 0 & 0 & 0 & 0 & 0 & 0 & 0 & 0 & 0 & 0 & 0 & 0 & 0 & 0 & 0 & 0 & 0 & 0 & 0 & 0 & 0 & 0 & 0 & 0 & 0 & 0 & 0 & 0 & 0 & 0 & 740 \\
\hline
\end{tabular}




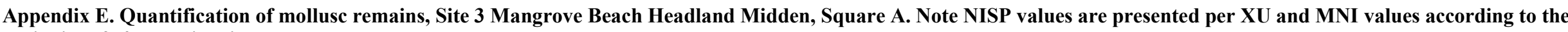
periodised 250-year time intervals.

\begin{tabular}{|c|c|c|c|c|c|c|c|c|c|c|c|c|c|c|c|c|c|c|c|c|}
\hline \multirow[b]{2}{*}{$\mathbf{X U}$} & \multirow[b]{2}{*}{ cal BP } & \multirow[b]{2}{*}{ Phylum } & \multirow[b]{2}{*}{ Class } & \multirow[b]{2}{*}{ Order/Family } & \multirow[b]{2}{*}{ Genus } & \multirow[b]{2}{*}{ Species } & \multirow[b]{2}{*}{ Side } & \multirow[b]{2}{*}{ NISP } & \multirow[b]{2}{*}{ MNI } & \multirow[b]{2}{*}{$\begin{array}{c}\text { Weight } \\
\text { (g) }\end{array}$} & \multicolumn{6}{|c|}{ Gastropod NREs } & \multicolumn{4}{|c|}{ Bivalve NREs } \\
\hline & & & & & & & & & & & $\stackrel{0}{\frac{\pi}{n}}$ & 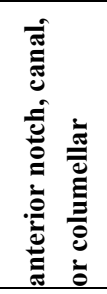 & 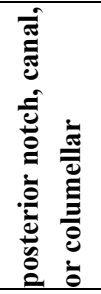 & 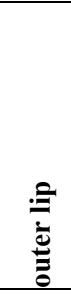 & 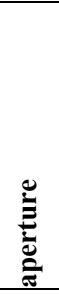 & 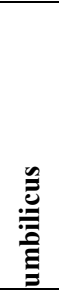 & 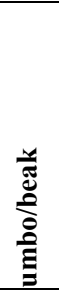 & 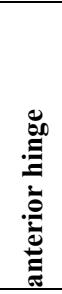 & 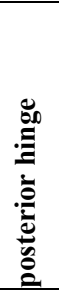 & 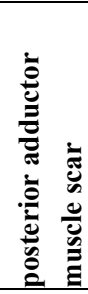 \\
\hline 1 & $500-750$ & Mollusca & & & & & & 1310 & & 77.02 & & & & & & & & & & \\
\hline 1 & $500-750$ & Mollusca & Gastropoda & & & & & 283 & & 75.03 & & & & & & & & & & \\
\hline 1 & $500-750$ & Mollusca & Bivalvia & & & & & 12 & & 8.57 & & & & & & & & & & \\
\hline 1 & $500-750$ & Mollusca & Gastropoda & Strombidae & & & & 74 & 6 & 34.52 & 5 & & & & & & & & & \\
\hline 1 & $500-750$ & Mollusca & Gastropoda & Strombidae & Conomurex & luhuanus & & 610 & 771 & 4299.18 & 590 & 307 & 179 & 111 & 98 & & & & & \\
\hline 1 & $500-750$ & Mollusca & Gastropoda & Strombidae & Lambis & lambis & & 11 & 12 & 247.1 & 3 & & 4 & 4 & 2 & & & & & \\
\hline 1 & $500-750$ & Mollusca & Gastropoda & Strombidae & Lambis & sp. & & 27 & 7 & 176.97 & & 2 & & & 1 & & & & & \\
\hline 1 & $500-750$ & Mollusca & Gastropoda & Tegulidae & & & & 1985 & 5 & 368.71 & & & & & & 5 & & & & \\
\hline 1 & $500-750$ & Mollusca & Gastropoda & Tegulidae & Rochia & nilotica & & 13 & 25 & 641.89 & 1 & & & 1 & 1 & 8 & & & & \\
\hline 1 & $500-750$ & Mollusca & Gastropoda & Rhytididae & & & & 5 & 3 & 0.41 & 2 & & & 1 & 1 & 2 & & & & \\
\hline 1 & $500-750$ & Mollusca & Bivalvia & Ostreidae & & & indet. & 1 & 1 & 0.05 & & & & & & & & & & \\
\hline 1 & $500-750$ & Mollusca & Gastropoda & Vermetidae & & & & 1 & 1 & 0.05 & & & & & & & & & & \\
\hline 1 & $500-750$ & Mollusca & Bivalvia & Cardiidae & Hippopus & hippopus & indet. & 1 & 1 & 0.26 & & & & & & & & & & \\
\hline 1 & $500-750$ & Mollusca & Gastropoda & Trochidae & Monodonta & labio & & 7 & 1 & 3.15 & & & & & & & & & & \\
\hline 1 & $500-750$ & Mollusca & Gastropoda & Muricidae & & & & 1 & 1 & 0.56 & & & & & & & & & & \\
\hline 1 & $500-750$ & Mollusca & Gastropoda & Muricidae & Thais & sp. & & 2 & 1 & 2.39 & & 1 & & & & & & & & \\
\hline 1 & $500-750$ & Mollusca & Gastropoda & Neritidae & Nerita & spp. & & 1 & 2 & 0.81 & & 1 & & 1 & & & & & & \\
\hline 1 & $500-750$ & Mollusca & Gastropoda & Neritidae & Nerita & polita & & 2 & 2 & 2.96 & 1 & & & & & & & & & \\
\hline 1 & $500-750$ & Mollusca & Bivalvia & Cardiidae & Tridacna & spp. & $1 \mathrm{~L}$ & 63 & 1 & 430.95 & & & & & & & & & 1 & \\
\hline 1 & $500-750$ & Mollusca & Bivalvia & Cardiidae & Tridacna & maxima & $5 \mathrm{R}$ & 5 & 4 & 465.62 & & & & & & & 3 & 4 & 3 & \\
\hline 1 & $500-750$ & Mollusca & Bivalvia & Cardiidae & Tridacna & maxima & $2 \mathrm{~L}$ & 2 & & & & & & & & & 1 & 1 & 1 & \\
\hline 1 & $500-750$ & Mollusca & Bivalvia & Cardiidae & Tridacna & maxima & indet. & 3 & & & & & & & & & & & & \\
\hline 1 & $500-750$ & Mollusca & Bivalvia & Cardiidae & Tridacna & gigas & $1 \mathrm{~L}$ & 1 & 1 & 12.37 & & & & & & & 1 & 1 & 1 & \\
\hline 1 & $500-750$ & Mollusca & Bivalvia & Cardiidae & Tridacna & crocea & $2 \mathrm{~L}$ & 2 & 3 & 86.3 & & & & & & & 2 & 2 & 2 & \\
\hline 2 & $500-750$ & Mollusca & & & & & & 1315 & & 36.25 & & & & & & & & & & \\
\hline 2 & $500-750$ & Mollusca & Gastropoda & & & & & 135 & & 39.75 & & & & & & & & & & \\
\hline
\end{tabular}




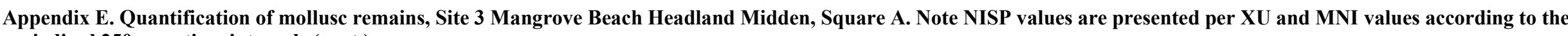
periodised 250-year time intervals (cont.).

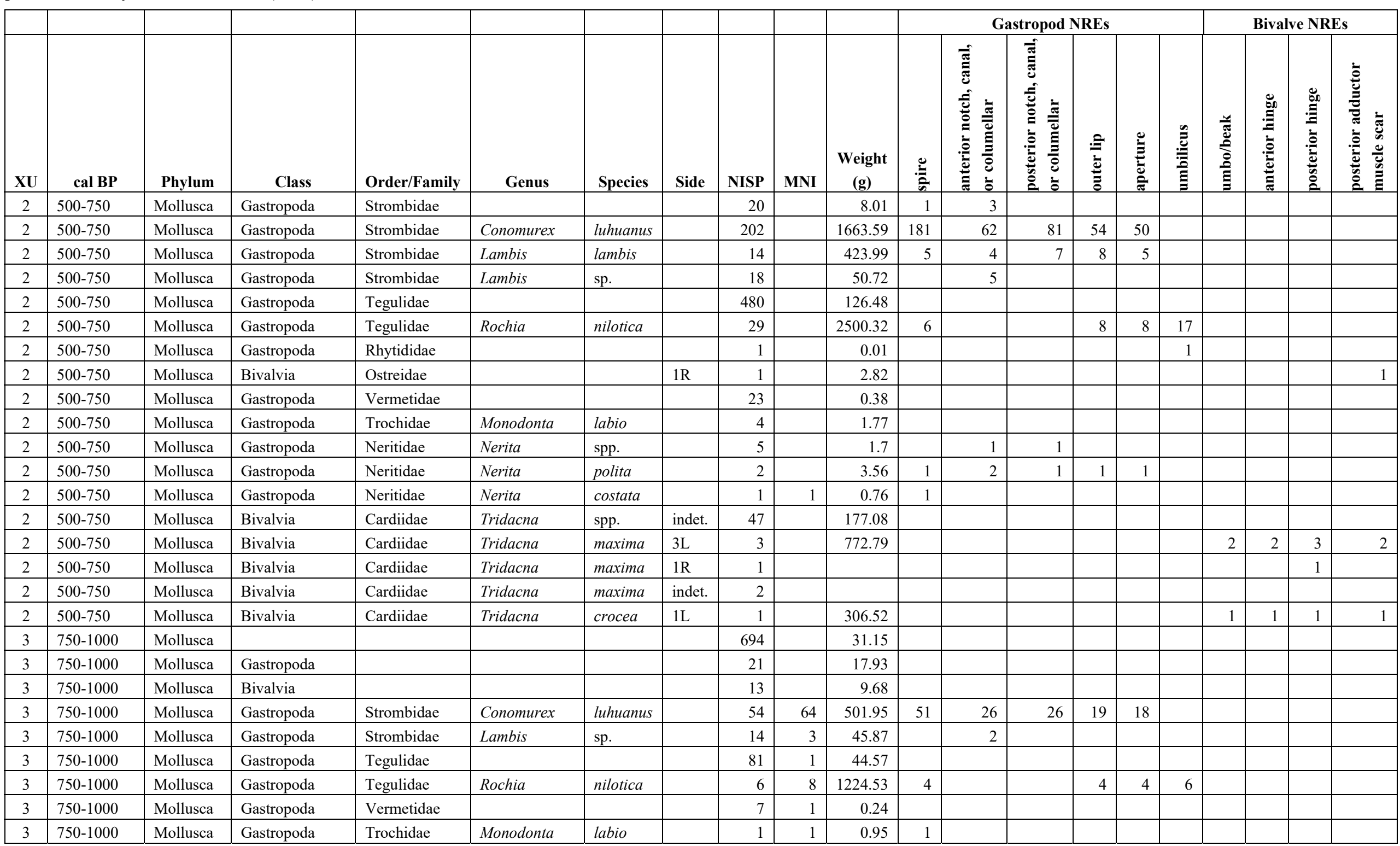




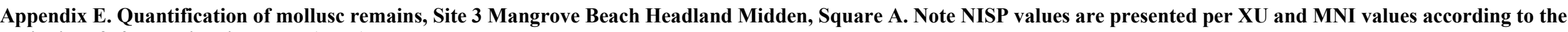
periodised 250-year time intervals (cont.).

\begin{tabular}{|c|c|c|c|c|c|c|c|c|c|c|c|c|c|c|c|c|c|c|c|c|}
\hline \multirow[b]{2}{*}{$\mathbf{X U}$} & \multirow[b]{2}{*}{ cal BP } & \multirow[b]{2}{*}{ Phylum } & \multirow[b]{2}{*}{ Class } & \multirow[b]{2}{*}{ Order/Family } & \multirow[b]{2}{*}{ Genus } & \multirow[b]{2}{*}{ Species } & \multirow[b]{2}{*}{ Side } & \multirow[b]{2}{*}{ NISP } & \multirow[b]{2}{*}{ MNI } & \multirow[b]{2}{*}{$\begin{array}{c}\text { Weight } \\
\text { (g) }\end{array}$} & \multicolumn{6}{|c|}{ Gastropod NREs } & \multicolumn{4}{|c|}{ Bivalve NREs } \\
\hline & & & & & & & & & & & $\stackrel{0}{\bar{z}}$ & 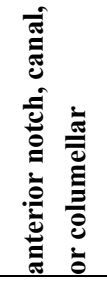 & 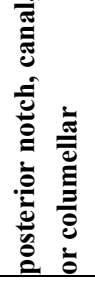 & 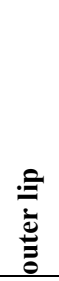 & $\begin{array}{l}\stackrel{0}{\Xi} \\
\stackrel{0}{0} \\
\stackrel{0}{\sigma}\end{array}$ & 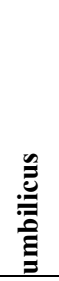 & 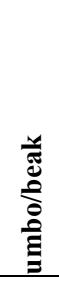 & 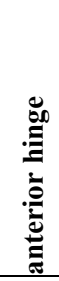 & 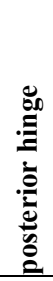 & 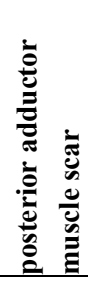 \\
\hline 3 & $750-1000$ & Mollusca & Gastropoda & Neritidae & Nerita & sp. & & 2 & 1 & 1 & & & & & & & & & & \\
\hline 3 & $750-1000$ & Mollusca & Gastropoda & Neritidae & Nerita & polita & & 4 & 3 & 2.39 & 3 & 1 & 1 & 1 & 1 & & & & & \\
\hline 3 & $750-1000$ & Mollusca & Cephalopoda & Sepiida & & & & 1 & 1 & 2.41 & & & & & & & & & & \\
\hline 3 & $750-1000$ & Mollusca & Bivalvia & Cardiidae & Tridacna & spp. & indet. & 17 & 1 & 81.32 & & & & & & & & & & \\
\hline 3 & $750-1000$ & Mollusca & Bivalvia & Cardiidae & Tridacna & maxima & $1 \mathrm{~L}$ & 1 & 2 & 488.22 & & & & & & & & & 1 & 1 \\
\hline 3 & $750-1000$ & Mollusca & Bivalvia & Cardiidae & Tridacna & maxima & $1 \mathrm{R}$ & 1 & & & & & & & & & 1 & 1 & 1 & 1 \\
\hline 3 & $750-1000$ & Mollusca & Bivalvia & Cardiidae & Tridacna & crocea & $1 \mathrm{R}$ & 1 & 1 & 165.9 & & & & & & & 1 & 1 & 1 & 1 \\
\hline 4 & $750-1000$ & Mollusca & & & & & & 183 & & 7.16 & & & & & & & & & & \\
\hline 4 & $750-1000$ & Mollusca & Gastropoda & & & & & 22 & & 3.23 & & & & & & & & & & \\
\hline 4 & $750-1000$ & Mollusca & Gastropoda & Strombidae & Conomurex & luhuanus & & 15 & & 124.97 & 13 & 7 & 7 & 7 & 7 & & & & & \\
\hline 4 & $750-1000$ & Mollusca & Gastropoda & Strombidae & Lambis & lambis & & 1 & 1 & 57.77 & 1 & 1 & 1 & 1 & 1 & & & & & \\
\hline 4 & $750-1000$ & Mollusca & Gastropoda & Strombidae & Lambis & sp. & & 1 & & 28.84 & 1 & 1 & 1 & & & & & & & \\
\hline 4 & $750-1000$ & Mollusca & Gastropoda & Tegulidae & & & & 10 & & 9.75 & & & & & & 1 & & & & \\
\hline 4 & $750-1000$ & Mollusca & Gastropoda & Tegulidae & Rochia & nilotica & & 2 & & 116.05 & 2 & & & 2 & 2 & 2 & & & & \\
\hline 4 & $750-1000$ & Mollusca & Bivalvia & Ostreidae & & & $\mathrm{L}$ & 1 & 1 & 0.2 & & & & & & & & & & 1 \\
\hline 4 & $750-1000$ & Mollusca & Gastropoda & Trochidae & Monodonta & labio & & 1 & & 0.81 & & & & & & & & & & \\
\hline 4 & $750-1000$ & Mollusca & Bivalvia & Cardiidae & Tridacna & sp. & indet. & 4 & & 9 & & & & & & & & & & \\
\hline 4 & $750-1000$ & Mollusca & Bivalvia & Cardiidae & Tridacna & maxima & $1 \mathrm{~L}$ & 1 & & 57.15 & & & & & & & 1 & 1 & 1 & \\
\hline 5 & $1000-1250$ & Mollusca & & & & & & 167 & & 5.62 & & & & & & & & & & \\
\hline 5 & $1000-1250$ & Mollusca & Gastropoda & & & & & 20 & & 3.31 & & & & & & & & & & \\
\hline 5 & $1000-1250$ & Mollusca & Gastropoda & Strombidae & & & & 3 & 1 & 1.8 & & & & & & & & & & \\
\hline 5 & $1000-1250$ & Mollusca & Gastropoda & Strombidae & Conomurex & luhuanus & & 7 & 7 & 47.34 & 7 & 3 & 3 & 3 & 3 & & & & & \\
\hline 5 & $1000-1250$ & Mollusca & Gastropoda & Strombidae & Lambis & sp. & & 1 & 1 & 0.26 & & & & & & & & & & \\
\hline 5 & $1000-1250$ & Mollusca & Gastropoda & Tegulidae & & & & 58 & 1 & 3.67 & & & & & & & & & & \\
\hline 5 & $1000-1250$ & Mollusca & Gastropoda & Tegulidae & Rochia & nilotica & & 3 & 3 & 707.81 & 1 & & & 3 & 3 & 3 & & & & \\
\hline 5 & $1000-1250$ & Mollusca & Gastropoda & Vermetidae & & & & 1 & 1 & 0.01 & & & & & & & & & & \\
\hline 5 & $1000-1250$ & Mollusca & Gastropoda & Rhytididae & & & & 1 & 1 & 0.01 & 1 & & & & & & & & & \\
\hline
\end{tabular}




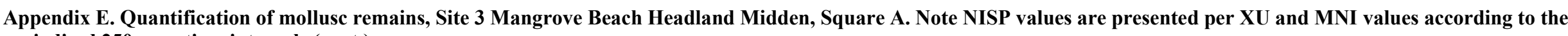
periodised 250-year time intervals (cont.).

\begin{tabular}{|c|c|c|c|c|c|c|c|c|c|c|c|c|c|c|c|c|c|c|c|c|}
\hline \multirow[b]{2}{*}{$\mathbf{X U}$} & \multirow[b]{2}{*}{ cal BP } & \multirow[b]{2}{*}{ Phylum } & \multirow[b]{2}{*}{ Class } & \multirow[b]{2}{*}{ Order/Family } & \multirow[b]{2}{*}{ Genus } & \multirow[b]{2}{*}{ Species } & \multirow[b]{2}{*}{ Side } & \multirow[b]{2}{*}{ NISP } & \multirow[b]{2}{*}{ MNI } & \multirow[b]{2}{*}{$\begin{array}{c}\text { Weight } \\
\text { (g) }\end{array}$} & \multicolumn{6}{|c|}{ Gastropod NREs } & \multicolumn{4}{|c|}{ Bivalve NREs } \\
\hline & & & & & & & & & & & : & 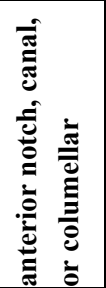 & 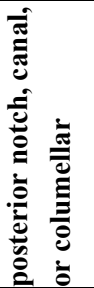 & 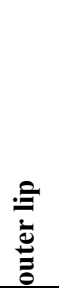 & 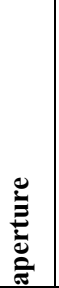 & 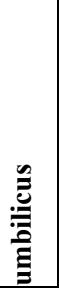 & 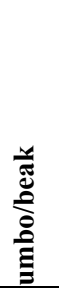 & 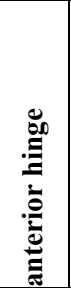 & 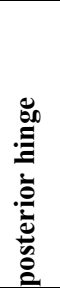 & 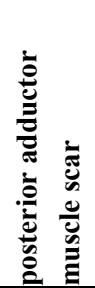 \\
\hline 6 & $1250-1500$ & Mollusca & & & & & & 31 & & 1.95 & & & & & & & & & & \\
\hline 6 & $1250-1500$ & Mollusca & Gastropoda & & & & & 125 & & 6.68 & & & & & & & & & & \\
\hline 6 & $1250-1500$ & Mollusca & Gastropoda & Strombidae & Conomurex & luhuanus & & 40 & 74 & 67.96 & 15 & 2 & 1 & & & & & & & \\
\hline 6 & $1250-1500$ & Mollusca & Gastropoda & Tegulidae & & & & 3 & 1 & 14.13 & & & & & & & & & & \\
\hline 6 & $1250-1500$ & Mollusca & Bivalvia & Cardiidae & Tridacna & sp. & indet. & 14 & 1 & 27.72 & & & & & & & & & & \\
\hline 7 & $1250-1500$ & Mollusca & & & & & & 145 & & 4.1 & & & & & & & & & & \\
\hline 7 & $1250-1500$ & Mollusca & Gastropoda & & & & & 77 & & 8.55 & & & & & & & & & & \\
\hline 7 & $1250-1500$ & Mollusca & Bivalvia & & & & & 3 & & 0.08 & & & & & & & & & & \\
\hline 7 & $1250-1500$ & Mollusca & Gastropoda & Conidae & Conus & sp. & & 1 & 1 & 63.94 & 1 & 1 & & & & & & & & \\
\hline 7 & $1250-1500$ & Mollusca & Gastropoda & Strombidae & Conomurex & luhuanus & & 140 & & 171.26 & 59 & & 1 & & & & & & & \\
\hline 7 & $1250-1500$ & Mollusca & Gastropoda & Tegulidae & & & & 73 & & 16.78 & & & & & & & & & & \\
\hline 7 & $1250-1500$ & Mollusca & Gastropoda & Tegulidae & Rochia & nilotica & & 2 & 2 & 9.74 & 2 & & & 1 & 1 & 1 & & & & \\
\hline 7 & $1250-1500$ & Mollusca & Bivalvia & Cardiidae & Tridacna & sp. & indet. & 17 & & 67.49 & & & & & & & & & & \\
\hline 7 & $1250-1500$ & Mollusca & Bivalvia & Cardiidae & Tridacna & maxima & $1 \mathrm{~L}$ & 1 & 1 & 43.07 & & & & & & & 1 & 1 & 1 & \\
\hline 7 & $1250-1500$ & Mollusca & Gastropoda & Trochidae & Monodonta & labio & & 1 & 1 & 0.36 & & & & & & & & & & \\
\hline 7 & $1250-1500$ & Mollusca & Bivalvia & Veneridae & Periglypta & puerpera & indet. & 1 & 1 & 0.91 & & & & & & & & & & \\
\hline 7 & $1250-1500$ & Mollusca & Cephalopoda & Nautilidae & Nautilus & sp. & & 1 & 1 & 16.46 & & & & & & & & & & \\
\hline 8 & $1500-1750$ & Mollusca & & & & & & 61 & & 0.97 & & & & & & & & & & \\
\hline 8 & $1500-1750$ & Mollusca & Gastropoda & & & & & 240 & & 13.65 & & & & & & & & & & \\
\hline 8 & $1500-1750$ & Mollusca & Gastropoda & Conidae & & & & 1 & 1 & 7.23 & & 1 & & & & & & & & \\
\hline 8 & $1500-1750$ & Mollusca & Gastropoda & Strombidae & & & & 13 & 5 & 6.18 & & 4 & & & & & & & & \\
\hline 8 & $1500-1750$ & Mollusca & Gastropoda & Strombidae & Conomurex & luhuanus & & 246 & 171 & 347.68 & 91 & 4 & 2 & & & & & & & \\
\hline 8 & $1500-1750$ & Mollusca & Gastropoda & Strombidae & Lambis & sp. & & 2 & 1 & 5.87 & & & & & & & & & & \\
\hline 8 & $1500-1750$ & Mollusca & Gastropoda & Tegulidae & & & & 124 & 1 & 126.81 & & & & & & & & & & \\
\hline 8 & $1500-1750$ & Mollusca & Gastropoda & Tegulidae & Rochia & nilotica & & 4 & 4 & 497.05 & 3 & & & 1 & 1 & 4 & & & & \\
\hline 8 & $1500-1750$ & Mollusca & Bivalvia & Cardiidae & Tridacna & sp. & indet. & 2 & 1 & 2.99 & & & & & & & & & & \\
\hline 8 & $1500-1750$ & Mollusca & Bivalvia & Cardiidae & Tridacna & maxima & $1 \mathrm{~L}$ & 1 & 3 & 60.91 & & & & & & & & & 1 & \\
\hline
\end{tabular}




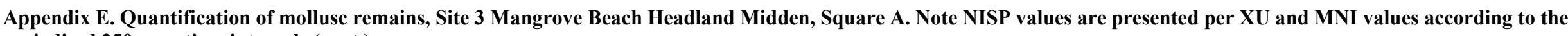
periodised 250-year time intervals (cont.).

\begin{tabular}{|c|c|c|c|c|c|c|c|c|c|c|c|c|c|c|c|c|c|c|c|c|}
\hline \multirow[b]{2}{*}{$\mathbf{X U}$} & \multirow[b]{2}{*}{ cal BP } & \multirow[b]{2}{*}{ Phylum } & \multirow[b]{2}{*}{ Class } & \multirow[b]{2}{*}{ Order/Family } & \multirow[b]{2}{*}{ Genus } & \multirow[b]{2}{*}{ Species } & \multirow[b]{2}{*}{ Side } & \multirow[b]{2}{*}{ NISP } & \multirow[b]{2}{*}{ MNI } & \multirow[b]{2}{*}{$\begin{array}{c}\text { Weight } \\
\text { (g) }\end{array}$} & \multicolumn{6}{|c|}{ Gastropod NREs } & \multicolumn{4}{|c|}{ Bivalve NREs } \\
\hline & & & & & & & & & & & $\stackrel{\frac{\pi}{a}}{\infty}$ & 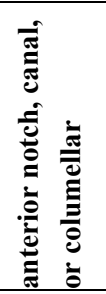 & 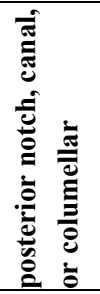 & 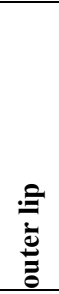 & 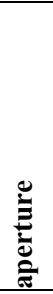 & 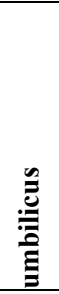 & 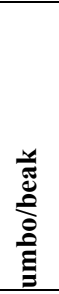 & 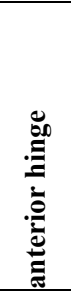 & 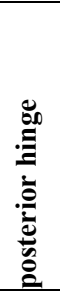 & 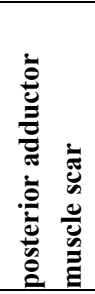 \\
\hline 8 & $1500-1750$ & Mollusca & Gastropoda & Vermetidae & & & & 21 & 1 & 0.58 & & & & & & & & & & \\
\hline 9 & $1500-1750$ & Mollusca & & & & & & 146 & & 3.45 & & & & & & & & & & \\
\hline 9 & $1500-1750$ & Mollusca & Gastropoda & & & & & 72 & & 6.74 & & & & & & & & & & \\
\hline 9 & $1500-1750$ & Mollusca & Gastropoda & Strombidae & & & & 3 & & 3.63 & & 1 & & & & & & & & \\
\hline 9 & $1500-1750$ & Mollusca & Gastropoda & Strombidae & Conomurex & luhuanus & & 173 & & 168.24 & 80 & 7 & 11 & & & & & & & \\
\hline 9 & $1500-1750$ & Mollusca & Gastropoda & Strombidae & Lambis & sp. & & 5 & & 24.18 & & & & & & & & & & \\
\hline 9 & $1500-1750$ & Mollusca & Gastropoda & Tegulidae & & & & 8 & & 10.19 & & & & & & & & & & \\
\hline 9 & $1500-1750$ & Mollusca & Bivalvia & Cardiidae & Tridacna & sp. & indet. & 2 & & 40.41 & & & & & & & & & & \\
\hline 9 & $1500-1750$ & Mollusca & Bivalvia & Ostreidae & & & indet. & 2 & & 0.3 & & & & & & & & & & \\
\hline 9 & $1500-1750$ & Mollusca & Gastropoda & Vermetidae & & & & 9 & & 0.26 & & & & & & & & & & \\
\hline 10 & $1750-2000$ & Mollusca & & & & & & 308 & & 6.17 & & & & & & & & & & \\
\hline 10 & $1750-2000$ & Mollusca & Gastropoda & & & & & 108 & & 11.38 & & & & & & & & & & \\
\hline 10 & $1750-2000$ & Mollusca & Bivalvia & & & & & 2 & & 0.53 & & & & & & & & & & \\
\hline 10 & $1750-2000$ & Mollusca & Gastropoda & Strombidae & Conomurex & luhuanus & & 120 & 87 & 265.39 & 66 & 1 & 5 & 1 & 1 & & & & & \\
\hline 10 & $1750-2000$ & Mollusca & Gastropoda & Strombidae & Lambis & sp. & & 2 & 1 & 73.14 & & & & 1 & 1 & & & & & \\
\hline 10 & $1750-2000$ & Mollusca & Gastropoda & Tegulidae & & & & 13 & 1 & 22.87 & & & & & & & & & & \\
\hline 10 & $1750-2000$ & Mollusca & Gastropoda & Tegulidae & Rochia & nilotica & & 2 & 3 & 65.58 & 1 & & & & & 2 & & & & \\
\hline 10 & $1750-2000$ & Mollusca & Bivalvia & Cardiidae & Tridacna & sp. & indet. & 5 & 1 & 22.68 & & & & & & & & & & \\
\hline 10 & $1750-2000$ & Mollusca & Bivalvia & Ostreidae & & & indet. & 9 & 1 & 2.76 & & & & & & & & & & \\
\hline 10 & $1750-2000$ & Mollusca & Polyplacophora & Chitonidae & Acanthopleura & gemmata & & 1 & 1 & 0.41 & & & & & & & & & & \\
\hline 11 & $1750-2000$ & Mollusca & & & & & & 133 & & 2.74 & & & & & & & & & & \\
\hline 11 & $1750-2000$ & Mollusca & Gastropoda & & & & & 18 & & 1.52 & & & & & & & & & & \\
\hline 11 & $1750-2000$ & Mollusca & Gastropoda & Strombidae & Conomurex & luhuanus & & 68 & & 94.51 & 21 & 1 & & & & & & & & \\
\hline
\end{tabular}




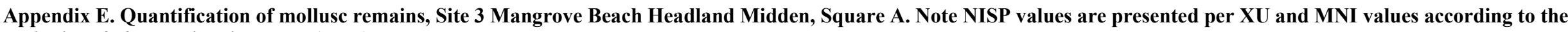
periodised 250-year time intervals (cont.).

\begin{tabular}{|c|c|c|c|c|c|c|c|c|c|c|c|c|c|c|c|c|c|c|c|c|}
\hline \multirow[b]{2}{*}{$\mathbf{X U}$} & \multirow[b]{2}{*}{ cal BP } & \multirow[b]{2}{*}{ Phylum } & \multirow[b]{2}{*}{ Class } & \multirow[b]{2}{*}{ Order/Family } & \multirow[b]{2}{*}{ Genus } & \multirow[b]{2}{*}{ Species } & \multirow[b]{2}{*}{ Side } & \multirow[b]{2}{*}{ NISP } & \multirow[b]{2}{*}{ MNI } & \multirow[b]{2}{*}{$\begin{array}{c}\text { Weight } \\
\text { (g) }\end{array}$} & \multicolumn{6}{|c|}{ Gastropod NREs } & \multicolumn{4}{|c|}{ Bivalve NREs } \\
\hline & & & & & & & & & & & $\stackrel{0}{\tilde{n}}$ & 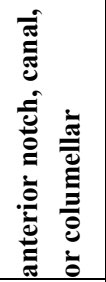 & 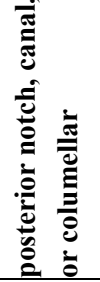 & $\begin{array}{l}\cong \\
\Xi \\
\stackrel{\Xi}{\Xi}\end{array}$ & 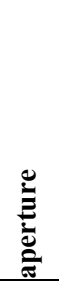 & 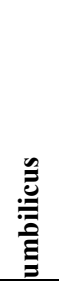 & 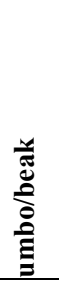 & 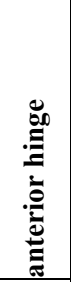 & 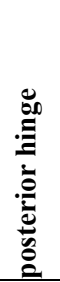 & 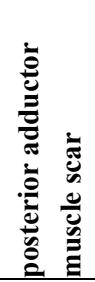 \\
\hline 11 & $1750-2000$ & Mollusca & Bivalvia & Cardiidae & Tridacna & $\mathrm{sp}$. & indet. & 2 & & 11.45 & & & & & & & & & & \\
\hline 12 & $2000-2250$ & Mollusca & & & & & & 56 & & 0.8 & & & & & & & & & & \\
\hline 12 & $2000-2250$ & Mollusca & Gastropoda & & & & & 22 & & 3.95 & & & & & & & & & & \\
\hline 12 & $2000-2250$ & Mollusca & Gastropoda & Strombidae & Conomurex & luhuanus & & 27 & 16 & 56.67 & 16 & & & & & & & & & \\
\hline 12 & $2000-2250$ & Mollusca & Gastropoda & Tegulidae & & & & 90 & 1 & 5.28 & & & & & & & & & & \\
\hline 12 & $2000-2250$ & Mollusca & Bivalvia & Cardiidae & Tridacna & maxima & $1 \mathrm{R}$ & 1 & 1 & 69.49 & & & & & & & 1 & 1 & 1 & 1 \\
\hline 12 & $2000-2250$ & Mollusca & Gastropoda & Veneridae & Periglypta & puerpera & indet. & 2 & 1 & 1.77 & & & & & & & & & & \\
\hline 13 & $2500-2750$ & Mollusca & Gastropoda & Tegulidae & & & & 3 & 1 & 0.68 & & & & & & & & & & \\
\hline 14 & $2750-3000$ & Mollusca & & & & & & 17 & & 0.35 & & & & & & & & & & \\
\hline 14 & $2750-3000$ & Mollusca & Gastropoda & & & & & 5 & & 0.31 & & & & & & & & & & \\
\hline 14 & $2750-3000$ & Mollusca & Gastropoda & Strombidae & Conomurex & luhuanus & & 6 & 2 & 2.66 & 2 & 1 & & & & & & & & \\
\hline 14 & $2750-3000$ & Mollusca & Gastropoda & Neritidae & Nerita & sp. & & 1 & 1 & 0.79 & & & 1 & 1 & 1 & & & & & \\
\hline 15 & $3000-3250$ & Mollusca & & & & & & 7 & & 1.28 & & & & & & & & & & \\
\hline 15 & $3000-3250$ & Mollusca & Gastropoda & & & & & 1 & & 0.65 & & & & & & & & & & \\
\hline 15 & $3000-3250$ & Mollusca & Gastropoda & Tegulidae & & & & 7 & 1 & 1.01 & & & & & & & & & & \\
\hline 16 & $3250-3500$ & Mollusca & & & & & & 1 & & 0.01 & & & & & & & & & & \\
\hline 16 & $3250-3500$ & Mollusca & Gastropoda & Strombidae & & & & 4 & 2 & 0.89 & & & & & & & & & & \\
\hline 17 & $3250-3500$ & Mollusca & & & & & & 14 & & 0.11 & & & & & & & & & & \\
\hline 17 & $3250-3500$ & Mollusca & Gastropoda & & & & & 2 & & 0.21 & & & & & & & & & & \\
\hline 17 & $3250-3500$ & Mollusca & Gastropoda & Strombidae & & & & 1 & & 1.22 & 1 & & & & & & & & & \\
\hline 18 & $3250-3500$ & Mollusca & Gastropoda & & & & & 3 & & 0.14 & & & & & & & & & & \\
\hline
\end{tabular}




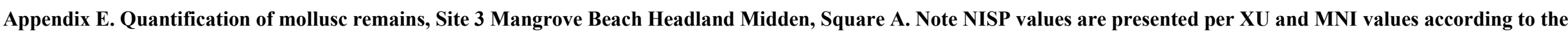
periodised 250-year time intervals (cont.).

\begin{tabular}{|c|c|c|c|c|c|c|c|c|c|c|c|c|c|c|c|c|c|c|c|c|}
\hline \multirow[b]{2}{*}{$\mathbf{X U}$} & \multirow[b]{2}{*}{ cal BP } & \multirow[b]{2}{*}{ Phylum } & \multirow[b]{2}{*}{ Class } & \multirow[b]{2}{*}{ Order/Family } & \multirow[b]{2}{*}{ Genus } & \multirow[b]{2}{*}{ Species } & \multirow[b]{2}{*}{ Side } & \multirow[b]{2}{*}{ NISP } & \multirow[b]{2}{*}{ MNI } & \multirow[b]{2}{*}{$\begin{array}{c}\text { Weight } \\
\text { (g) }\end{array}$} & \multicolumn{6}{|c|}{ Gastropod NREs } & \multicolumn{4}{|c|}{ Bivalve NREs } \\
\hline & & & & & & & & & & & $\stackrel{0}{\overrightarrow{0}}$ & 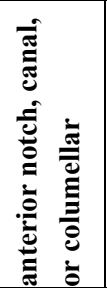 & 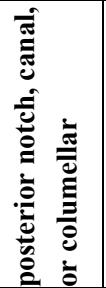 & $\begin{array}{l}\stackrel{\Xi}{\Xi} \\
\vdots \\
\stackrel{\Xi}{\Xi}\end{array}$ & 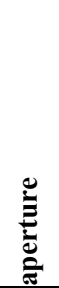 & 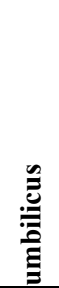 & 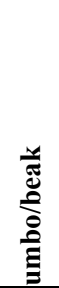 & 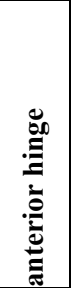 & 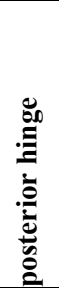 & 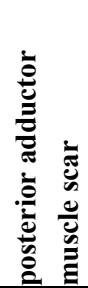 \\
\hline 20 & $3250-3500$ & Mollusca & & & & & & 4 & & 0.06 & & & & & & & & & & \\
\hline 21 & $3250-3500$ & Mollusca & Gastropoda & & & & & 5 & & 0.08 & & & & & & & & & & \\
\hline 22 & $3250-3500$ & Mollusca & & & & & & 8 & & 0.1 & & & & & & & & & & \\
\hline 23 & $3250-3500$ & Mollusca & & & & & & 8 & & 0.06 & & & & & & & & & & \\
\hline 24 & $3250-3500$ & Mollusca & & & & & & 7 & & 0.15 & & & & & & & & & & \\
\hline 24 & $3250-3500$ & Mollusca & Gastropoda & & & & & 6 & & 0.09 & & & & & & & & & & \\
\hline 26 & $3250-3500$ & Mollusca & & & & & & 1 & & 0.02 & & & & & & & & & & \\
\hline 28 & $3250-3500$ & Mollusca & Gastropoda & Tegulidae & Rochia & nilotica & & 3 & 1 & 15.42 & & & & & & & & & & \\
\hline 29 & $3250-3500$ & Mollusca & & & & & & 3 & & 0.26 & & & & & & & & & & \\
\hline 30 & $3250-3500$ & Mollusca & Gastropoda & & & & & 1 & & 0.59 & & & & & & & & & & \\
\hline 31 & $3250-3500$ & Mollusca & & & & & & 1 & & 0.06 & & & & & & & & & & \\
\hline 42 & $4000-4250$ & Mollusca & & & & & & 3 & & 0.02 & & & & & & & & & & \\
\hline 50 & $4250-4500$ & Mollusca & & & & & & 2 & & 0.01 & & & & & & & & & & \\
\hline & & Total & & & & & & 11127 & 1356 & 20100.51 & & & & & & & & & & \\
\hline
\end{tabular}




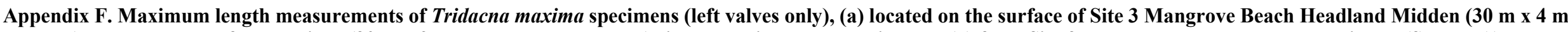

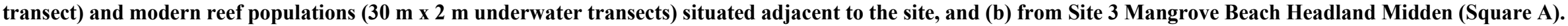

(a)

\begin{tabular}{|c|c|c|c|c|c|}
\hline Sample & $n$ & Mean (mm) & Range \pm s.d. $(\sigma)(\mathrm{mm})$ & \% Juveniles & \% Adults \\
\hline Archaeological population $(\sim 500 \mathrm{cal} \mathrm{BP})$ & 74 & 120.96 & $76.32-176.23 \pm 21.59$ & 91 & 9 \\
\hline Reef population (modern) & 115 & 152.97 & $8.00-360.00 \pm 82.25$ & 48 & 52 \\
\hline
\end{tabular}

(b)

\begin{tabular}{|l|l|r|r|c|r|r|}
\hline \multicolumn{1}{|c|}{ XU } & \multicolumn{1}{|c|}{ cal BP } & \multicolumn{1}{c|}{$\boldsymbol{n}$} & Mean $(\mathbf{m m})$ & \multicolumn{1}{c|}{ Range \pm s.d. $(\boldsymbol{\sigma})(\mathbf{m m})$} & \% Juveniles & \multicolumn{1}{c|}{ \% Adults } \\
\hline $1-2$ & $500-750$ & 5 & 143.47 & $87.47-179.41 \pm 30.59$ & 60 & 40 \\
\hline 3 & $750-1000$ & 1 & 174.16 & - & 0 & 100 \\
\hline 7 & $1250-1500$ & 1 & 112.05 & - & 100 & 0 \\
\hline $8-9$ & $1500-1750$ & 3 & 119.67 & $96.21-165.13 \pm 32.15$ & 67 & 33 \\
\hline
\end{tabular}


Appendix G: Quantification of fish remains, Site 3 Mangrove Beach Headland Midden, Square A.

\begin{tabular}{|c|c|c|c|c|c|c|c|c|c|}
\hline XU & cal BP & Class & Family & Genus & Species & Element & NISP & MNI & $\begin{array}{c}\text { Weight } \\
\text { (g) }\end{array}$ \\
\hline 1 & $500-750$ & Actinopterygii & Scaridae & & & tooth & 2 & 1 & 0.10 \\
\hline 1 & $500-750$ & Actinopterygii & Scaridae & & & dentary or premaxilla & 1 & - & 0.14 \\
\hline 1 & $500-750$ & Actinopterygii & & & & unknown (too fragmented) & 29 & - & 0.78 \\
\hline 2 & $500-750$ & Actinopterygii & Scaridae & & & dentary or premaxilla & 1 & - & 0.84 \\
\hline 2 & $500-750$ & Actinopterygii & Scaridae & & & tooth & 1 & - & 0.02 \\
\hline 2 & $500-750$ & Actinopterygii & & & & unknown (too fragmented) & 51 & - & 2.55 \\
\hline 3 & $750-1000$ & Actinopterygii & Scaridae & & & tooth & 1 & 1 & 0.04 \\
\hline 3 & $750-1000$ & Actinopterygii & & & & unknown (too fragmented) & 61 & - & 2.27 \\
\hline 4 & $750-1000$ & Actinopterygii & Scaridae & & & tooth & 3 & - & 0.10 \\
\hline 4 & $750-1000$ & Actinopterygii & & & & unknown (too fragmented) & 23 & - & 0.53 \\
\hline 5 & $1000-1250$ & Actinopterygii & & & & unknown (too fragmented) & 1 & - & 0.02 \\
\hline 5 & $1000-1250$ & Actinopterygii & Scaridae & & & tooth & 1 & 1 & 0.02 \\
\hline 6 & $1250-1500$ & Actinopterygii & & & & unknown (too fragmented) & 1 & - & 0.01 \\
\hline 6 & $1250-1500$ & Actinopterygii & & & & tooth & 2 & - & 0.12 \\
\hline 6 & $1250-1500$ & Actinopterygii & & & & unknown (too fragmented) & 6 & - & 0.06 \\
\hline 7 & $1250-1500$ & Actinopterygii & Scaridae & & & dentary or premaxilla & 1 & 1 & 0.02 \\
\hline 7 & $1250-1500$ & Actinopterygii & & & & unknown (too fragmented) & 4 & - & 0.08 \\
\hline 7 & $1250-1500$ & Actinopterygii & Scaridae & Bolbometopon & muricatum & tooth & 1 & 1 & 0.01 \\
\hline 7 & $1250-1500$ & Elasmobranchii & & & & vertebra (unknown type) & 1 & 1 & 0.02 \\
\hline 8 & $1500-1750$ & Actinopterygii & Scaridae & & & tooth & 1 & 1 & 0.01 \\
\hline 8 & $1500-1750$ & Actinopterygii & Scaridae & & & tooth & 1 & - & 0.03 \\
\hline 8 & $1500-1750$ & Actinopterygii & & & & tooth & 1 & - & 0.07 \\
\hline 8 & $1500-1750$ & Actinopterygii & & & & unknown (too fragmented) & 2 & - & 0.04 \\
\hline 9 & $1500-1750$ & Actinopterygii & & & & unknown (too fragmented) & 7 & - & 0.15 \\
\hline 10 & $1750-2000$ & Actinopterygii & Scaridae & Bolbometopon & muricatum & dentary or premaxilla & 1 & 1 & 0.11 \\
\hline 10 & $1750-2000$ & Actinopterygii & Scaridae & & & tooth & 1 & 1 & 0.10 \\
\hline 10 & $1750-2000$ & Actinopterygii & & & & unknown (too fragmented) & 4 & - & 0.11 \\
\hline 10 & $1750-2000$ & Elasmobranchii & & & & vertebra (unknown type) & 1 & 1 & 0.00 \\
\hline 11 & $1750-2000$ & Actinopterygii & & & & unknown (too fragmented) & 1 & - & 0.03 \\
\hline 12 & $2000-2250$ & Actinopterygii & Scaridae & & & tooth & 2 & 1 & 0.05 \\
\hline 12 & $2000-2250$ & Actinopterygii & & & & unknown (too fragmented) & 5 & - & 0.18 \\
\hline 13 & $2500-2750$ & Actinopterygii & Scaridae & & & tooth & 2 & 1 & 0.02 \\
\hline 13 & $2500-2750$ & Actinopterygii & & & & unknown (too fragmented) & 1 & - & 0.01 \\
\hline 14 & $2750-3000$ & Actinopterygii & Scaridae & & & tooth & 1 & 1 & 0.02 \\
\hline 14 & $2750-3000$ & Actinopterygii & Scaridae & & & dentary or premaxilla & 1 & - & 0.03 \\
\hline 15 & $3000-3250$ & Actinopterygii & Scaridae & & & tooth & 1 & 1 & 0.01 \\
\hline 15 & $3000-3250$ & Actinopterygii & & & & unknown (too fragmented) & 2 & - & 0.30 \\
\hline 16 & $3250-3500$ & Actinopterygii & & & & unknown (too fragmented) & 1 & - & 0.03 \\
\hline 22 & $3250-3500$ & Actinopterygii & Scaridae & & & tooth & 1 & 1 & 0.01 \\
\hline 24 & $3250-3500$ & Actinopterygii & Scaridae & & & tooth & 1 & - & 0.02 \\
\hline 24 & $3250-3500$ & Actinopterygii & & & & unknown (too fragmented) & 3 & - & 0.05 \\
\hline 25 & $3250-3500$ & Actinopterygii & & & & unknown (too fragmented) & 1 & - & 0.01 \\
\hline 25 & $3250-3500$ & Actinopterygii & Scaridae & & & tooth & 3 & - & 0.07 \\
\hline 27 & $3250-3500$ & Actinopterygii & & & & unknown (too fragmented) & 1 & - & 0.02 \\
\hline \multirow[t]{2}{*}{28} & $3250-3500$ & Actinopterygii & Scaridae & & & tooth & 1 & - & 0.05 \\
\hline & & Total & & & & & 238 & 15 & 9.26 \\
\hline
\end{tabular}


Appendix H. Stone artefact analysis, Site 3 Mangrove Beach Headland Midden, Square A.

\begin{tabular}{|c|c|c|c|c|c|c|c|c|c|c|}
\hline $\mathbf{X U}$ & $\begin{array}{c}\text { Object } \\
\# \\
\end{array}$ & Raw Material & $\begin{array}{c}\text { Fracture } \\
\text { Type } \\
\end{array}$ & $\begin{array}{c}\text { Fragment } \\
\text { Category }\end{array}$ & $\begin{array}{c}\text { Weight } \\
\text { (g) }\end{array}$ & $\begin{array}{c}\text { Length } \\
(\mathrm{mm})\end{array}$ & $\begin{array}{l}\text { Width } \\
(\mathrm{mm})\end{array}$ & $\begin{array}{c}\text { Thickness } \\
(\mathrm{mm})\end{array}$ & $\begin{array}{c}\text { Elongation } \\
(\mathbf{m m})\end{array}$ & $\begin{array}{c}\text { Angle } \\
\left({ }^{\circ}\right) \\
\end{array}$ \\
\hline 1 & 1 & Quartz & Bipolar Core & Complete & 5.06 & 23.28 & 22.00 & 6.49 & 1.06 & - \\
\hline 1 & - & Quartz & Flake & Complete & 1.96 & 19.47 & 15.36 & 5.41 & 1.27 & 79 \\
\hline 1 & - & Quartz & Flaked Piece & - & 2.27 & - & - & - & - & - \\
\hline 1 & - & Quartz & Flake & Complete & 0.58 & 15.44 & 9.92 & 2.54 & 1.56 & 43 \\
\hline 1 & - & Quartz & Flake & Complete & 0.37 & 6.26 & 11.54 & 3.08 & 0.54 & 52 \\
\hline 1 & - & Quartz & Flake & Complete & 0.62 & 15.24 & 11.05 & 2.83 & 1.38 & 59 \\
\hline 1 & - & Quartz & Flake & Proximal & 0.02 & - & - & - & - & - \\
\hline 1 & - & Quartz & Flake & Complete & 1.1 & 14.98 & 10.08 & 5.97 & 1.49 & 45 \\
\hline 1 & - & Quartz & Flake & Complete & 0.97 & 8.20 & 13.63 & 5.87 & 0.60 & 56 \\
\hline 1 & - & Quartz & Flake & Complete & 0.04 & 5.00 & 5.83 & 1.20 & 0.86 & 74 \\
\hline 1 & - & Quartz & Flake & Left & 0.02 & - & - & - & - & - \\
\hline 1 & - & Quartz & Flake & Complete & 0.08 & 3.84 & 5.17 & 2.60 & 0.74 & 63 \\
\hline 1 & - & Quartz & Flake & Distal & 0.04 & - & - & - & - & - \\
\hline 1 & - & Quartz & Flake & Complete & 0.01 & 7.16 & 6.09 & 0.89 & 1.18 & 78 \\
\hline 1 & - & Quartz & Flake & Complete & 0.04 & 7.09 & 3.31 & 1.68 & 2.14 & 51 \\
\hline 1 & - & Quartz & Flake & Marginal & 0.04 & - & - & - & - & - \\
\hline 1 & - & Quartz & Flake & Distal & 0.3 & - & - & - & - & - \\
\hline 1 & - & Quartz & Flake & Complete & 0.19 & 5.87 & 7.19 & 1.88 & 0.82 & 32 \\
\hline 1 & - & Quartz & Flake & Complete & 0.11 & 5.29 & 5.82 & 1.41 & 0.91 & 72 \\
\hline 1 & - & Quartz & Flake & Complete & 0.08 & 3.64 & 6.75 & 0.82 & 0.54 & 32 \\
\hline 1 & - & Crystal Quartz & Flake & Complete & 0.03 & 6.37 & 1.84 & 0.89 & 3.46 & 53 \\
\hline 1 & - & Quartz & Flake & Distal & 0.03 & - & - & - & - & - \\
\hline 1 & - & Quartz & Flake & Complete & 0.03 & 3.27 & 4.80 & 0.99 & 0.68 & 40 \\
\hline 1 & - & Quartz & Flake & Complete & 0.02 & 5.93 & 3.35 & 1.03 & 1.77 & 67 \\
\hline 1 & - & Quartz & Flake & Marginal & 0.02 & - & - & - & - & - \\
\hline 1 & - & Quartz & Flake & Complete & 0.02 & 3.14 & 3.44 & 1.29 & 0.91 & 53 \\
\hline 1 & - & Quartz & Flake & Marginal & 0.01 & - & - & - & - & - \\
\hline 1 & - & Quartz & Flake & Marginal & 0.02 & - & - & - & - & - \\
\hline 1 & - & Quartz & Flaked Piece & - & 0.01 & - & - & - & - & - \\
\hline 1 & - & Quartz & Flake & Marginal & 0.01 & - & - & - & - & - \\
\hline 1 & - & Quartz & Flaked Piece & - & 0.02 & - & - & - & - & - \\
\hline 1 & - & Quartz & Flaked Piece & - & 0.02 & - & - & - & - & - \\
\hline 1 & - & Quartz & Flaked Piece & - & 0.03 & - & - & - & - & - \\
\hline 1 & - & Quartz & Flaked Piece & - & 0.02 & - & - & - & - & - \\
\hline 1 & - & Quartz & Flake & Complete & 0.04 & 6.37 & 5.64 & 2.31 & 1.13 & 70 \\
\hline 1 & - & Quartz & Flake & Proximal & 0.17 & - & - & - & - & - \\
\hline 1 & - & Quartz & Flake & Medial & 0.08 & - & - & - & - & - \\
\hline 1 & - & Quartz & Flake & Distal & 0.33 & - & - & - & - & - \\
\hline 1 & - & Quartz & Flake & Right & 0.02 & - & - & - & - & - \\
\hline 1 & - & Quartz & Flaked Piece & - & 3.35 & - & - & - & - & - \\
\hline 1 & - & Quartz & Flaked Piece & - & 0.18 & - & - & - & - & - \\
\hline 1 & - & Quartz & Flaked Piece & - & 0.01 & - & - & - & - & - \\
\hline 2 & 2 & Quartz & Flake & Complete & 7.66 & 38.63 & 15.93 & 11.95 & 2.42 & 77 \\
\hline 2 & 3 & Quartz & Bipolar Flake & Complete & 0.56 & 17.77 & 10.98 & 3.30 & 1.62 & 70 \\
\hline 2 & - & Crystal Quartz & Flake & Complete & 0.15 & 6.94 & 5.59 & 2.41 & 1.24 & 64 \\
\hline 2 & - & Quartz & Flake & Complete & 0.86 & 17.58 & 9.23 & 5.56 & 1.90 & 66 \\
\hline 2 & - & Quartz & Flake & Complete & 0.24 & 9.76 & 12.51 & 2.14 & 0.78 & 86 \\
\hline 2 & - & Quartz & Flake & Complete & 0.07 & 6.28 & 6.83 & 1.22 & 0.92 & 73 \\
\hline 2 & - & Quartz & Flake & Distal & 0.12 & - & - & - & - & - \\
\hline 2 & - & Quartz & Flake & Distal & 0.09 & - & - & - & - & - \\
\hline 2 & - & Crystal Quartz & Flake & Left & 0.06 & - & - & - & - & - \\
\hline
\end{tabular}


Appendix H. Stone artefact analysis, Site 3 Mangrove Beach Headland Midden, Square A (cont.).

\begin{tabular}{|c|c|c|c|c|c|c|c|c|c|c|}
\hline $\mathbf{X U}$ & $\begin{array}{c}\text { Object } \\
\# \\
\end{array}$ & Raw Material & $\begin{array}{c}\text { Fracture } \\
\text { Type }\end{array}$ & $\begin{array}{c}\text { Fragment } \\
\text { Category }\end{array}$ & $\begin{array}{c}\text { Weight } \\
\text { (g) }\end{array}$ & $\begin{array}{c}\text { Length } \\
(\mathrm{mm})\end{array}$ & $\begin{array}{c}\text { Width } \\
(\mathrm{mm})\end{array}$ & $\begin{array}{c}\text { Thickness } \\
(\mathrm{mm})\end{array}$ & $\begin{array}{c}\text { Elongation } \\
(\mathbf{m m})\end{array}$ & $\begin{array}{c}\text { Angle } \\
\left({ }^{\circ}\right) \\
\end{array}$ \\
\hline 2 & - & Quartz & Flake & Proximal & 0.04 & - & - & - & - & - \\
\hline 2 & - & Quartz & Flake & Left & 0.04 & - & - & - & - & - \\
\hline 2 & - & Quartz & Flake & Marginal & 0.02 & - & - & - & - & - \\
\hline 2 & - & Quartz & Flake & Marginal & 0.03 & - & - & - & - & - \\
\hline 2 & - & Quartz & Bipolar Core & Complete & 1.17 & 16.09 & 10.14 & 6.03 & 1.59 & - \\
\hline 3 & 1 & Quartz & Flake & Complete & 9.83 & 28.55 & 18.54 & 10.59 & 1.54 & 82 \\
\hline 3 & 2 & Quartz & Flake & Complete & 16.3 & 22.33 & 31.43 & 20.50 & 0.71 & 38 \\
\hline 3 & 3 & Quartz & Flake & Proximal & 0.94 & - & - & - & - & - \\
\hline 3 & 7 & Quartz & Flake & Complete & 3.51 & 21.24 & 21.92 & 6.70 & 0.97 & 78 \\
\hline 3 & - & Quartz & Flake & Complete & 0.11 & 14.72 & 4.99 & 1.12 & 2.95 & 74 \\
\hline 3 & - & Quartz & Flake & Complete & 0.04 & 9.47 & 2.14 & 1.44 & 4.43 & 75 \\
\hline 3 & - & Quartz & Flake & Complete & 0.08 & 5.65 & 8.98 & 1.57 & 0.63 & 68 \\
\hline 3 & - & Quartz & Flake & Right & 0.02 & - & - & - & - & - \\
\hline 3 & - & Quartz & Flake & Marginal & 0.02 & - & - & - & - & - \\
\hline 3 & - & Quartz & Flake & Medial & 0.04 & - & - & - & - & - \\
\hline 3 & - & Quartz & Flake & Medial & 0.01 & - & - & - & - & - \\
\hline 3 & - & Quartz & Flake & Distal & 0.2 & - & - & - & - & - \\
\hline 3 & - & Quartz & Flake & Distal & 0.65 & - & - & - & - & - \\
\hline 3 & - & Quartz & Flake & Distal & 0.21 & - & - & - & - & - \\
\hline 3 & - & Quartz & Flake & Distal & 0.07 & - & - & - & - & - \\
\hline 3 & - & Quartz & Flake & Distal & 0.06 & - & - & - & - & - \\
\hline 3 & - & Quartz & Flake & Distal & 0.09 & - & - & - & - & - \\
\hline 3 & - & Quartz & Flake & Distal & 0.02 & - & - & - & - & - \\
\hline 4 & - & Quartz & Flake & Complete & 0.11 & 6.89 & 7.09 & 1.89 & 0.97 & 70 \\
\hline 4 & - & Quartz & Flake & Complete & 0.1 & 8.94 & 6.49 & 1.96 & 1.38 & 83 \\
\hline 4 & - & Quartz & Flake & Complete & 0.08 & 10.32 & 4.56 & 1.68 & 2.26 & 76 \\
\hline 4 & - & Quartz & Flake & Medial & 0.98 & - & - & - & - & - \\
\hline 4 & - & Quartz & Flake & Medial & 0.02 & - & - & - & - & - \\
\hline 4 & - & Quartz & Flake & Distal & 0.03 & - & - & - & - & - \\
\hline 4 & - & Quartz & Flake & Distal & 0.06 & - & - & - & - & - \\
\hline 4 & - & Quartz & Flake & Distal & 0.04 & - & - & - & - & - \\
\hline 4 & - & Quartz & Flake & Distal & 0.01 & - & - & - & - & - \\
\hline 4 & - & Quartz & Flake & Distal & 0.01 & - & - & - & - & - \\
\hline 5 & 1 & Quartz & Flake & Left & 1.06 & - & - & - & - & - \\
\hline 5 & - & Quartz & Flake & Complete & 0.09 & 6.13 & 9.79 & 1.27 & 0.63 & 43 \\
\hline 5 & - & Quartz & Flake & Complete & 0.03 & 5.89 & 5.77 & 0.94 & 1.02 & 73 \\
\hline 5 & - & Quartz & Flake & Complete & 0.03 & 5.14 & 4.36 & 1.05 & 1.18 & 75 \\
\hline 5 & - & Crystal Quartz & Flake & Marginal & 0.02 & - & - & - & - & - \\
\hline 5 & - & Quartz & Flake & Left & 0.16 & - & - & - & - & - \\
\hline 5 & - & Quartz & Flake & Distal & 0.01 & - & - & - & - & - \\
\hline 6 & 1 & Quartz & Flake & Complete & 0.53 & 13.42 & 7.92 & 3.45 & 1.69 & 60 \\
\hline 6 & - & Quartz & Flake & Complete & 3.39 & 26.76 & 15.05 & 6.37 & 1.78 & 105 \\
\hline 6 & - & Quartz & Flake & Complete & 0.86 & 14.37 & 15.55 & 3.01 & 0.92 & 58 \\
\hline 6 & - & Quartz & Flake & Complete & 0.18 & 10.79 & 7.74 & 1.74 & 1.39 & 67 \\
\hline 6 & - & Quartz & Flake & Complete & 0.23 & 7.55 & 9.88 & 2.33 & 0.76 & 74 \\
\hline 6 & - & Quartz & Flake & Complete & 0.09 & 12.46 & 4.83 & 1.05 & 2.58 & 74 \\
\hline 6 & - & Quartz & Flake & Complete & 0.04 & 4.42 & 5.51 & 1.36 & 0.80 & 62 \\
\hline 6 & - & Quartz & Flake & Complete & 0.05 & 5.33 & 4.31 & 1.46 & 1.24 & 56 \\
\hline 6 & - & Quartz & Flake & Complete & 0.07 & 6.49 & 5.55 & 1.79 & 1.17 & 70 \\
\hline 6 & - & Quartz & Flake & Complete & 0.03 & 4.67 & 5.75 & 0.98 & 0.81 & 60 \\
\hline 6 & - & Quartz & Flake & Marginal & 0.06 & - & - & - & - & - \\
\hline
\end{tabular}


Appendix H. Stone artefact analysis, Site 3 Mangrove Beach Headland Midden, Square A (cont.).

\begin{tabular}{|c|c|c|c|c|c|c|c|c|c|c|}
\hline $\mathbf{X U}$ & $\begin{array}{c}\text { Object } \\
\#\end{array}$ & Raw Material & $\begin{array}{c}\text { Fracture } \\
\text { Type }\end{array}$ & $\begin{array}{c}\text { Fragment } \\
\text { Category }\end{array}$ & $\begin{array}{c}\text { Weight } \\
\text { (g) }\end{array}$ & $\begin{array}{c}\text { Length } \\
(\mathrm{mm})\end{array}$ & $\begin{array}{l}\text { Width } \\
(\mathrm{mm})\end{array}$ & $\begin{array}{c}\text { Thickness } \\
\text { (mm) }\end{array}$ & $\begin{array}{c}\text { Elongation } \\
(\mathbf{m m})\end{array}$ & $\begin{array}{c}\text { Angle } \\
\left({ }^{\circ}\right)\end{array}$ \\
\hline 6 & - & Quartz & Flake & Distal & 0.12 & - & - & - & - & - \\
\hline 6 & - & Quartz & Flake & Distal & 0.01 & - & - & - & - & - \\
\hline 6 & - & Quartz & Flake & Distal & 0.01 & - & - & - & - & - \\
\hline 6 & - & Quartz & Flake & Distal & 0.01 & - & - & - & - & - \\
\hline 6 & - & Quartz & Flake & Distal & 0.02 & - & - & - & - & - \\
\hline 6 & - & Quartz & Flaked Piece & - & 4.3 & - & - & - & - & - \\
\hline 6 & - & Quartz & Flake & Complete & 0.3 & 8.93 & 8.61 & 3.04 & 1.04 & 72 \\
\hline 6 & - & Quartz & Flake & Complete & 0.05 & 2.50 & 10.08 & 1.08 & 0.25 & 69 \\
\hline 7 & 1 & Quartz & Flake & Distal & 0.06 & - & - & - & - & - \\
\hline 7 & 9 & Quartz & Flake & Complete & 0.13 & 3.82 & 8.37 & 2.23 & 0.46 & 47 \\
\hline 7 & - & Quartz & Flake & Complete & 0.21 & 8.03 & 7.04 & 2.69 & 1.14 & 55 \\
\hline 7 & - & Quartz & Flake & Complete & 0.05 & 4.31 & 5.49 & 1.21 & 0.79 & 49 \\
\hline 7 & - & Quartz & Flake & Complete & 0.01 & 4.05 & 2.53 & 0.72 & 1.60 & 69 \\
\hline 7 & - & Quartz & Flake & Complete & 0.02 & 3.59 & 3.92 & 1.15 & 0.92 & 60 \\
\hline 7 & - & Quartz & Flake & Complete & 0.03 & 4.84 & 2.98 & 1.51 & 1.62 & 68 \\
\hline 7 & - & Quartz & Flake & Complete & 0.01 & 2.67 & 4.14 & 0.75 & 0.64 & 70 \\
\hline 7 & - & Quartz & Flake & Marginal & 0.02 & - & - & - & - & - \\
\hline 7 & - & Quartz & Flake & Medial & 0.36 & - & - & - & - & - \\
\hline 7 & - & Quartz & Flake & Distal & 0.05 & - & - & - & - & - \\
\hline 7 & - & Quartz & Flake & Distal & 0.06 & - & - & - & - & - \\
\hline 7 & - & Quartz & Flake & Distal & 0.16 & - & - & - & - & - \\
\hline 7 & - & Quartz & Flake & Distal & 0.02 & - & - & - & - & - \\
\hline 7 & - & Quartz & Flake & Distal & 0.01 & - & - & - & - & - \\
\hline 7 & - & Quartz & Flake & Distal & 0.01 & - & - & - & - & - \\
\hline 7 & - & Quartz & Flake & Distal & 0.01 & - & - & - & - & - \\
\hline 7 & - & Quartz & Flake & Distal & 0.02 & - & - & - & - & - \\
\hline 8 & 1 & Quartz & Bipolar Flake & Complete & 1.23 & 18.43 & 9.64 & 5.35 & 1.91 & 92 \\
\hline 8 & 2 & Quartz & Bipolar Flake & Complete & 0.11 & 6.60 & 5.20 & 2.18 & 1.27 & 75 \\
\hline 8 & 6 & Quartz & Flake & Complete & 0.52 & 9.86 & 11.43 & 3.91 & 0.86 & 69 \\
\hline 8 & - & Quartz & Flake & Complete & 0.45 & 7.23 & 12.23 & 3.63 & 0.59 & 56 \\
\hline 8 & - & Quartz & Bipolar Flake & Complete & 0.32 & 14.09 & 7.30 & 2.68 & 1.93 & 69 \\
\hline 8 & - & Quartz & Flake & Complete & 0.07 & 5.11 & 7.61 & 0.82 & 0.67 & 57 \\
\hline 8 & - & Quartz & Flake & Complete & 0.09 & 6.92 & 4.81 & 1.79 & 1.44 & 79 \\
\hline 8 & - & Quartz & Flake & Complete & 0.09 & 7.94 & 5.68 & 1.75 & 1.40 & 76 \\
\hline 8 & - & Quartz & Flake & Complete & 0.03 & 5.21 & 3.28 & 1.23 & 1.59 & 49 \\
\hline 8 & - & Quartz & Flake & Complete & 0.02 & 4.49 & 4.12 & 0.71 & 1.09 & 28 \\
\hline 8 & - & Quartz & Flake & Marginal & 0.02 & - & - & - & - & - \\
\hline 8 & - & Quartz & Flake & Complete & 0.36 & 11.84 & 7.65 & 3.92 & 1.55 & 75 \\
\hline 8 & - & Quartz & Flake & Medial & 0.37 & - & - & - & - & - \\
\hline 8 & - & Quartz & Flake & Medial & 0.4 & - & - & - & - & - \\
\hline 8 & - & Quartz & Flake & Distal & 0.04 & - & - & - & - & - \\
\hline 8 & - & Quartz & Flake & Distal & 0.13 & - & - & - & - & - \\
\hline 8 & - & Quartz & Flake & Distal & 0.02 & - & - & - & - & - \\
\hline 8 & - & Quartz & Flake & Distal & 0.02 & - & - & - & - & - \\
\hline 8 & - & Quartz & Flake & Distal & 0.06 & - & - & - & - & - \\
\hline 8 & - & Quartz & Flake & Distal & 0.01 & - & - & - & - & - \\
\hline 9 & 2 & Quartz & Bipolar Flake & Complete & 3.26 & 16.46 & 17.78 & 8.05 & 0.93 & 54 \\
\hline 9 & 5 & Quartz & Microblade & Complete & 0.22 & 13.65 & 4.75 & 2.13 & 2.87 & 57 \\
\hline 9 & 12 & Quartz & Flake & Complete & 2.35 & 11.10 & 17.04 & 10.29 & 0.65 & 40 \\
\hline 9 & 14 & Quartz & Flake & Distal & 3.23 & - & - & - & - & - \\
\hline 9 & 16 & Quartz & Flake & Complete & 0.08 & 6.12 & 5.57 & 1.42 & 1.10 & 69 \\
\hline
\end{tabular}


Appendix H. Stone artefact analysis, Site 3 Mangrove Beach Headland Midden, Square A (cont.).

\begin{tabular}{|c|c|c|c|c|c|c|c|c|c|c|}
\hline $\mathbf{X U}$ & $\begin{array}{c}\text { Object } \\
\# \\
\end{array}$ & Raw Material & $\begin{array}{c}\text { Fracture } \\
\text { Type }\end{array}$ & $\begin{array}{c}\text { Fragment } \\
\text { Category }\end{array}$ & $\begin{array}{c}\text { Weight } \\
\text { (g) }\end{array}$ & $\begin{array}{c}\text { Length } \\
(\mathrm{mm})\end{array}$ & $\begin{array}{l}\text { Width } \\
(\mathrm{mm})\end{array}$ & $\begin{array}{c}\text { Thickness } \\
(\mathrm{mm})\end{array}$ & $\begin{array}{c}\text { Elongation } \\
(\mathrm{mm})\end{array}$ & $\begin{array}{c}\text { Angle } \\
\left({ }^{\circ}\right)\end{array}$ \\
\hline 9 & - & Quartz & Flake & Complete & 0.48 & 11.56 & 12.27 & 3.50 & 0.94 & 67 \\
\hline 9 & - & Quartz & Flake & Complete & 0.35 & 6.30 & 11.42 & 2.52 & 0.55 & 30 \\
\hline 9 & - & Quartz & Flake & Complete & 0.06 & 5.89 & 5.74 & 1.61 & 1.03 & 75 \\
\hline 9 & - & Quartz & Flake & Complete & 0.02 & 6.46 & 4.97 & 0.80 & 1.30 & 73 \\
\hline 9 & - & Quartz & Flake & Complete & 0.04 & 6.55 & 5.12 & 0.73 & 1.28 & 78 \\
\hline 9 & - & Quartz & Flake & Complete & 0.01 & 3.63 & 4.42 & 0.66 & 0.82 & 84 \\
\hline 9 & - & Quartz & Flake & Right & 0.6 & - & - & - & - & - \\
\hline 9 & - & Quartz & Flake & Marginal & 0.05 & - & - & - & - & - \\
\hline 9 & - & Quartz & Flake & Proximal & 0.12 & - & - & - & - & - \\
\hline 9 & - & Quartz & Flake & Distal & 0.04 & - & - & - & - & - \\
\hline 9 & - & Quartz & Flake & Right & 0.06 & - & - & - & - & - \\
\hline 10 & 3 & Quartz & Flake & Complete & 1.3 & 16.75 & 14.12 & 4.98 & 1.19 & 67 \\
\hline 10 & 4 & Quartz & Flake & Complete & 0.78 & 11.36 & 9.37 & 3.05 & 1.21 & 68 \\
\hline 10 & 5 & Quartz & Flake & Proximal & 1.14 & - & - & - & - & - \\
\hline 10 & 6 & Quartz & Flake & Proximal & 0.5 & - & - & - & - & - \\
\hline 10 & 9 & Quartz & Bipolar Core & Complete & 11.15 & 29.86 & 22.03 & 15.06 & 1.36 & - \\
\hline 10 & 10 & Quartz & Flaked Piece & - & 4.88 & - & - & - & - & - \\
\hline 10 & - & Quartz & Flake & Complete & 0.62 & 11.90 & 10.36 & 2.99 & 1.15 & 71 \\
\hline 10 & - & Quartz & Flake & Complete & 0.4 & 13.27 & 12.61 & 3.06 & 1.05 & 68 \\
\hline 10 & - & Quartz & Flake & Complete & 0.2 & 9.78 & 9.33 & 1.75 & 1.05 & 64 \\
\hline 10 & - & Quartz & Flake & Complete & 0.23 & 8.98 & 7.08 & 2.52 & 1.27 & 91 \\
\hline 10 & - & Quartz & Flake & Complete & 0.19 & 7.98 & 10.10 & 1.83 & 0.79 & 87 \\
\hline 10 & - & Quartz & Flake & Complete & 0.01 & 5.29 & 5.08 & 0.46 & 1.04 & 72 \\
\hline 10 & - & Quartz & Flake & Proximal & 0.06 & - & - & - & - & - \\
\hline 10 & - & Quartz & Flake & Left & 0.29 & - & - & - & - & - \\
\hline 10 & - & Quartz & Flake & Distal & 0.05 & - & - & - & - & - \\
\hline 10 & - & Quartz & Flake & Medial & 0.3 & - & - & - & - & - \\
\hline 10 & - & Quartz & Flake & Distal & 0.19 & - & - & - & - & - \\
\hline 10 & - & Quartz & Flake & Complete & 0.27 & 4.40 & 9.65 & 2.81 & 0.46 & 51 \\
\hline 10 & - & Quartz & Flake & Distal & 0.03 & - & - & - & - & - \\
\hline 10 & - & Quartz & Bipolar Flake & Complete & 0.21 & 7.24 & 9.98 & 2.00 & 0.73 & 74 \\
\hline 10 & - & Quartz & Flake & Complete & 0.13 & 5.17 & 9.77 & 1.83 & 0.53 & 71 \\
\hline 10 & - & Quartz & Flake & Complete & 0.07 & 3.33 & 6.11 & 2.16 & 0.55 & 48 \\
\hline 10 & - & Quartz & Flake & Complete & 0.05 & 6.28 & 4.36 & 1.45 & 1.44 & 43 \\
\hline 10 & - & Quartz & Flake & Complete & 0.01 & 4.19 & 3.88 & 0.97 & 1.08 & 79 \\
\hline 10 & - & Quartz & Flake & Marginal & 0.03 & - & - & - & - & - \\
\hline 10 & - & Quartz & Flake & Distal & 0.03 & - & - & - & - & - \\
\hline 11 & 1 & Quartz & Flake & Complete & 2.62 & 22.53 & 14.94 & 4.86 & 1.51 & 46 \\
\hline 11 & 2 & Quartz & Bipolar Flake & Complete & 0.48 & 15.47 & 7.31 & 2.74 & 2.12 & 68 \\
\hline 11 & 3 & Quartz & Flake & Distal & 0.13 & - & - & - & - & - \\
\hline 11 & 4 & Quartz & Flaked Piece & - & 1.02 & - & - & - & - & - \\
\hline 11 & 13 & Quartz & Flaked Piece & - & 1.7 & - & - & - & - & - \\
\hline 11 & 16 & Quartz & Flake & Distal & 0.05 & - & - & - & - & - \\
\hline 11 & - & Crystal Quartz & Flake & Complete & 0.4 & 14.79 & 9.15 & 2.02 & 1.62 & 64 \\
\hline 11 & - & Quartz & Flake & Complete & 0.16 & 9.56 & 8.09 & 2.08 & 1.18 & 74 \\
\hline 11 & - & Quartz & Flake & Complete & 0.07 & 8.05 & 5.92 & 1.20 & 1.36 & 73 \\
\hline 11 & - & Quartz & Flake & Complete & 0.06 & 5.49 & 6.11 & 1.26 & 0.90 & 71 \\
\hline 11 & - & Quartz & Flake & Proximal & 0.1 & - & - & - & - & - \\
\hline 11 & - & Quartz & Flake & Distal & 0.04 & - & - & - & - & - \\
\hline 11 & - & Quartz & Flake & Distal & 0.02 & - & - & - & - & - \\
\hline 11 & - & Quartz & Flake & Distal & 0.03 & - & - & - & - & - \\
\hline
\end{tabular}


Appendix H. Stone artefact analysis, Site 3 Mangrove Beach Headland Midden, Square A (cont.).

\begin{tabular}{|c|c|c|c|c|c|c|c|c|c|c|}
\hline $\mathbf{X U}$ & $\begin{array}{c}\text { Object } \\
\# \\
\end{array}$ & Raw Material & $\begin{array}{c}\text { Fracture } \\
\text { Type }\end{array}$ & $\begin{array}{c}\text { Fragment } \\
\text { Category }\end{array}$ & $\begin{array}{c}\text { Weight } \\
\text { (g) }\end{array}$ & $\begin{array}{c}\text { Length } \\
(\mathrm{mm})\end{array}$ & $\begin{array}{l}\text { Width } \\
(\mathrm{mm})\end{array}$ & $\begin{array}{c}\text { Thickness } \\
(\mathrm{mm})\end{array}$ & $\begin{array}{c}\text { Elongation } \\
(\mathbf{m m})\end{array}$ & $\begin{array}{c}\text { Angle } \\
\left({ }^{\circ}\right) \\
\end{array}$ \\
\hline 12 & - & Quartz & Bipolar Flake & Complete & 2.35 & 32.14 & 9.76 & 4.49 & 3.29 & 74 \\
\hline 12 & - & Quartz & Core & Complete & 1.58 & 9.18 & 23.29 & 5.93 & 0.39 & - \\
\hline 12 & - & Crystal Quartz & Flake & Complete & 0.16 & 9.73 & 7.41 & 1.68 & 1.31 & 77 \\
\hline 12 & - & Quartz & Flake & Complete & 0.2 & 7.79 & 8.93 & 2.87 & 0.87 & 54 \\
\hline 12 & - & Quartz & Flake & Proximal & 1.03 & - & - & - & - & - \\
\hline 12 & - & Quartz & Flake & Distal & 0.07 & - & - & - & - & - \\
\hline 12 & - & Quartz & Flake & Distal & 0.13 & - & - & - & - & - \\
\hline 12 & - & Quartz & Flake & Distal & 0.01 & - & - & - & - & - \\
\hline 12 & - & Quartz & Flake & Complete & 0.48 & 8.17 & 8.74 & 6.13 & 0.93 & 58 \\
\hline 13 & - & Quartz & Flake & Complete & 0.04 & 5.60 & 4.74 & 1.44 & 1.18 & 77 \\
\hline 14 & 1 & Quartz & Bipolar Core & Complete & 3.78 & 27.74 & 14.96 & 8.68 & 1.85 & - \\
\hline 14 & - & Quartz & Flake & Right & 0.22 & - & - & - & - & - \\
\hline 14 & - & Quartz & Flake & Complete & 0.09 & 6.99 & 4.05 & 2.33 & 1.73 & 60 \\
\hline 15 & 2 & Quartz & Flake & Complete & 0.09 & 7.73 & 6.51 & 1.37 & 1.19 & 74 \\
\hline 15 & - & Crystal Quartz & Flake & Complete & 0.02 & 5.68 & 3.04 & 0.88 & 1.87 & 74 \\
\hline 15 & - & Crystal Quartz & Flake & Marginal & 0.01 & - & - & - & - & - \\
\hline 15 & - & Crystal Quartz & Flake & Distal & 0.01 & - & - & - & - & - \\
\hline 15 & - & Crystal Quartz & Flake & Distal & 0.01 & - & - & - & - & - \\
\hline 16 & - & Crystal Quartz & Flake & Complete & 0.01 & 4.97 & 3.81 & 0.90 & 1.30 & 58 \\
\hline 16 & - & Quartz & Flake & Complete & 0.02 & 6.28 & 5.05 & 0.68 & 1.24 & 68 \\
\hline 16 & - & Quartz & Flake & Proximal & 0.17 & - & - & - & - & - \\
\hline 16 & - & Quartz & Flake & Distal & 0.01 & - & - & - & - & - \\
\hline 17 & - & Quartz & Flake & Distal & 0.01 & - & - & - & - & - \\
\hline 18 & - & Quartz & Flake & Medial & 0.03 & - & - & - & - & - \\
\hline 19 & 8 & Quartz & Flake & Medial & 0.02 & - & - & - & - & - \\
\hline 19 & - & Quartz & Flake & Complete & 0.07 & 6.54 & 4.68 & 2.23 & 1.40 & 55 \\
\hline 19 & - & Quartz & Flake & Complete & 0.12 & 6.61 & 6.21 & 1.90 & 1.06 & 58 \\
\hline 19 & - & Quartz & Flake & Distal & 0.06 & - & - & - & - & - \\
\hline 19 & - & Quartz & Flake & Distal & 0.02 & - & - & - & - & - \\
\hline 19 & - & Quartz & Flake & Distal & 0.01 & - & - & - & - & - \\
\hline 20 & - & Quartz & Flake & Distal & 0.04 & - & - & - & - & - \\
\hline 20 & - & Quartz & Flake & Distal & 0.1 & - & - & - & - & - \\
\hline 20 & - & Crystal Quartz & Flake & Distal & 0.02 & - & - & - & - & - \\
\hline 21 & - & Quartz & Flake & Proximal & 0.05 & - & - & - & - & - \\
\hline 21 & - & Quartz & Flake & Medial & 0.08 & - & - & - & - & - \\
\hline 21 & - & Quartz & Flake & Distal & 0.64 & - & - & - & - & - \\
\hline 21 & - & Quartz & Flake & Distal & 0.16 & - & - & - & - & - \\
\hline 21 & - & Quartz & Flake & Distal & 0.26 & - & - & - & - & - \\
\hline 21 & - & Quartz & Flake & Distal & 0.01 & - & - & - & - & - \\
\hline 21 & - & Quartz & Flake & Distal & 0.03 & - & - & - & - & - \\
\hline 22 & 10 & Quartz & Flake & Distal & 0.24 & - & - & - & - & - \\
\hline 22 & 11 & Quartz & Flake & Left & 0.13 & - & - & - & - & - \\
\hline 22 & 15 & Crystal Quartz & Flake & Complete & 0.58 & 11.72 & 11.95 & 2.96 & 0.98 & 74 \\
\hline 22 & - & Quartz & Flake & Complete & 0.04 & 8.57 & 4.50 & 1.19 & 1.90 & 76 \\
\hline 22 & - & Quartz & Flake & Complete & 0.03 & 8.93 & 4.80 & 0.78 & 1.86 & 73 \\
\hline 22 & - & Quartz & Flake & Left & 1.39 & - & - & - & - & - \\
\hline 22 & - & Quartz & Flake & Right & 4.38 & - & - & - & - & - \\
\hline 22 & - & Quartz & Flake & Distal & 2.36 & - & - & - & - & - \\
\hline 22 & - & Quartz & Flake & Distal & 0.22 & - & - & - & - & - \\
\hline 22 & - & Quartz & Flake & Distal & 0.04 & - & - & - & - & - \\
\hline 22 & - & Quartz & Flake & Distal & 0.01 & - & - & - & - & - \\
\hline
\end{tabular}


Appendix H. Stone artefact analysis, Site 3 Mangrove Beach Headland Midden, Square A (cont.).

\begin{tabular}{|c|c|c|c|c|c|c|c|c|c|c|}
\hline $\mathbf{X U}$ & $\begin{array}{c}\text { Object } \\
\# \\
\end{array}$ & Raw Material & $\begin{array}{c}\text { Fracture } \\
\text { Type }\end{array}$ & $\begin{array}{c}\text { Fragment } \\
\text { Category }\end{array}$ & $\begin{array}{c}\text { Weight } \\
\text { (g) }\end{array}$ & $\begin{array}{c}\text { Length } \\
(\mathrm{mm})\end{array}$ & $\begin{array}{l}\text { Width } \\
(\mathrm{mm})\end{array}$ & $\begin{array}{c}\text { Thickness } \\
\text { (mm) }\end{array}$ & $\begin{array}{c}\text { Elongation } \\
(\mathbf{m m})\end{array}$ & $\begin{array}{c}\text { Angle } \\
\left({ }^{\circ}\right) \\
\end{array}$ \\
\hline 22 & - & Quartz & Flake & Proximal & 0.04 & - & - & - & - & - \\
\hline 22 & - & Quartz & Flaked Piece & - & 0.01 & - & - & - & - & - \\
\hline 23 & 1 & Quartz & Flake & Complete & 4.44 & 21.03 & 29.85 & 5.43 & 0.70 & 50 \\
\hline 23 & 20 & Quartz & Flake & Complete & 1.31 & 21.95 & 8.70 & 4.62 & 2.52 & 61 \\
\hline 23 & 23 & Quartz & Flake & Complete & 2.63 & 13.91 & 23.77 & 3.09 & 0.59 & 76 \\
\hline 23 & 32 & Quartz & Flake & Left & 0.47 & - & - & - & - & - \\
\hline 23 & 33 & Sedimentary & Flake & Proximal & 2.37 & - & - & - & - & - \\
\hline 23 & 41 & Quartz & Flake & Complete & 0.47 & 19.82 & 11.10 & 1.67 & 1.79 & 62 \\
\hline 23 & - & Quartz & Bipolar Core & Complete & 1.91 & 22.66 & 5.42 & 10.06 & 4.18 & - \\
\hline 23 & - & Crystal Quartz & Flake & Complete & 0.27 & 17.24 & 6.23 & 1.95 & 2.77 & 79 \\
\hline 23 & - & Quartz & Flake & Complete & 0.66 & 22.60 & 4.97 & 5.80 & 4.55 & 89 \\
\hline 23 & - & Quartz & Flake & Complete & 0.03 & 3.65 & 6.35 & 1.30 & 0.57 & 79 \\
\hline 23 & - & Quartz & Flake & Complete & 0.03 & 5.00 & 5.07 & 1.49 & 0.99 & 67 \\
\hline 23 & - & Quartz & Flake & Proximal & 0.02 & - & - & - & - & - \\
\hline 23 & - & Quartz & Flake & Left & 0.1 & - & - & - & - & - \\
\hline 23 & - & Crystal Quartz & Flake & Right & 0.25 & - & - & - & - & - \\
\hline 23 & - & Quartz & Flake & Distal & 0.19 & - & - & - & - & - \\
\hline 23 & - & Quartz & Flake & Distal & 0.03 & - & - & - & - & - \\
\hline 23 & - & Quartz & Flake & Medial & 0.01 & - & - & - & - & - \\
\hline 23 & - & Quartz & Flaked Piece & - & 0.03 & - & - & - & - & - \\
\hline 23 & - & Granite & Flake & Medial & 0.58 & - & - & - & - & - \\
\hline 24 & 5 & Quartz & Flake & Complete & 0.16 & 9.22 & 7.11 & 1.98 & 1.30 & 88 \\
\hline 24 & 13 & Quartz & Flaked Piece & - & 0.04 & - & - & - & - & - \\
\hline 24 & 14 & Quartz & Flake & Complete & 1.42 & 14.49 & 14.27 & 5.48 & 1.02 & 83 \\
\hline 24 & 15 & Quartz & Flake & Right & 0.27 & - & - & - & - & - \\
\hline 24 & 57 & Quartz & Flake & Complete & 3.72 & 32.92 & 21.40 & 4.12 & 1.54 & 70 \\
\hline 24 & - & Quartz & Flake & Complete & 0.48 & 8.90 & 16.12 & 2.52 & 0.55 & 49 \\
\hline 24 & - & Quartz & Flake & Complete & 0.26 & 7.08 & 8.97 & 2.20 & 0.79 & 54 \\
\hline 24 & - & Quartz & Flake & Complete & 0.08 & 6.93 & 5.83 & 1.21 & 1.19 & 75 \\
\hline 24 & - & Quartz & Flake & Complete & 0.13 & 6.12 & 7.26 & 2.29 & 0.84 & 61 \\
\hline 24 & - & Quartz & Flake & Complete & 0.06 & 4.35 & 8.90 & 1.22 & 0.49 & 49 \\
\hline 24 & - & Quartz & Flake & Complete & 0.03 & 5.89 & 4.48 & 1.02 & 1.31 & 67 \\
\hline 24 & - & Quartz & Flake & Complete & 0.08 & 4.32 & 6.90 & 1.69 & 0.63 & 43 \\
\hline 24 & - & Quartz & Flake & Complete & 0.04 & 4.73 & 5.29 & 1.43 & 0.89 & 43 \\
\hline 24 & - & Quartz & Flake & Complete & 0.01 & 4.46 & 3.28 & 0.59 & 1.36 & 48 \\
\hline 24 & - & Quartz & Flake & Proximal & 0.09 & - & - & - & - & - \\
\hline 24 & - & Quartz & Flake & Proximal & 0.07 & - & - & - & - & - \\
\hline 24 & - & Quartz & Flake & Proximal & 0.03 & - & - & - & - & - \\
\hline 24 & - & Quartz & Flake & Distal & 0.07 & - & - & - & - & - \\
\hline 24 & - & Quartz & Flake & Distal & 0.46 & - & - & - & - & - \\
\hline 24 & - & Quartz & Flake & Distal & 0.22 & - & - & - & - & - \\
\hline 24 & - & Quartz & Flake & Distal & 0.01 & - & - & - & - & - \\
\hline 24 & - & Quartz & Flaked Piece & - & 0.36 & - & - & - & - & - \\
\hline 25 & 13 & Quartz & Flake & Complete & 0.99 & 18.83 & 9.42 & 3.75 & 2.00 & 66 \\
\hline 25 & - & Quartz & Flake & Complete & 0.11 & 5.86 & 6.52 & 2.03 & 0.90 & 73 \\
\hline 25 & - & Quartz & Flake & Complete & 0.1 & 5.19 & 7.24 & 2.06 & 0.72 & 75 \\
\hline 25 & - & Quartz & Flake & Proximal & 0.17 & - & - & - & - & - \\
\hline 25 & - & Quartz & Flake & Medial & 0.01 & - & - & - & - & - \\
\hline 25 & - & Quartz & Flake & Distal & 0.03 & - & - & - & - & - \\
\hline 25 & - & Quartz & Flake & Distal & 0.02 & - & - & - & - & - \\
\hline
\end{tabular}


Appendix H. Stone artefact analysis, Site 3 Mangrove Beach Headland Midden, Square A (cont.).

\begin{tabular}{|c|c|c|c|c|c|c|c|c|c|c|}
\hline $\mathbf{X U}$ & $\begin{array}{c}\text { Object } \\
\# \\
\end{array}$ & Raw Material & $\begin{array}{c}\text { Fracture } \\
\text { Type }\end{array}$ & $\begin{array}{c}\text { Fragment } \\
\text { Category }\end{array}$ & $\begin{array}{c}\text { Weight } \\
\text { (g) }\end{array}$ & $\begin{array}{c}\text { Length } \\
(\mathrm{mm})\end{array}$ & $\begin{array}{l}\text { Width } \\
(\mathrm{mm})\end{array}$ & $\begin{array}{c}\text { Thickness } \\
(\mathrm{mm})\end{array}$ & $\begin{array}{c}\text { Elongation } \\
(\mathrm{mm})\end{array}$ & $\begin{array}{c}\text { Angle } \\
\left({ }^{\circ}\right)\end{array}$ \\
\hline 25 & - & Quartz & $\begin{array}{l}\text { Ground Edge } \\
\text { Fragment }\end{array}$ & - & 0.09 & - & - & - & - & - \\
\hline 25 & - & Quartz & Flaked Piece & - & 0.02 & - & - & - & - & - \\
\hline 25 & - & Quartz & Flaked Piece & - & 0.01 & - & - & - & - & - \\
\hline 26 & 13 & Quartz & Flake & Distal & 0.49 & - & - & - & - & - \\
\hline 26 & - & Quartz & Flake & Proximal & 0.03 & - & - & - & - & - \\
\hline 26 & - & Quartz & Flake & Distal & 0.02 & - & - & - & - & - \\
\hline 26 & - & Quartz & Flake & Medial & 0.01 & - & - & - & - & - \\
\hline 27 & - & Quartz & Flake & Left & 0.03 & - & - & - & - & - \\
\hline 27 & - & Quartz & Flake & Distal & 0.01 & - & - & - & - & - \\
\hline 28 & 3 & Quartz & Flake & Complete & 1.38 & 10.72 & 14.18 & 7.10 & 0.76 & 68 \\
\hline 28 & - & Quartz & Flake & Complete & 0.04 & 4.73 & 5.52 & 1.19 & 0.86 & 79 \\
\hline 28 & - & Quartz & Flake & Marginal & 0.01 & - & - & - & - & - \\
\hline 29 & 8 & Quartz & Flake & Complete & 0.66 & 8.19 & 13.13 & 3.03 & 0.62 & 59 \\
\hline 29 & - & Quartz & Flake & Proximal & 0.01 & - & - & - & - & - \\
\hline 29 & - & Quartz & Flake & Distal & 0.02 & - & - & - & - & - \\
\hline 29 & - & Quartz & Flake & Distal & 0.03 & - & - & - & - & - \\
\hline 29 & - & Quartz & Flake & Marginal & 0.01 & - & - & - & - & - \\
\hline 30 & 6 & Quartz & Flaked Piece & - & 3.49 & - & - & - & - & - \\
\hline 30 & - & Crystal Quartz & Flake & Marginal & 0.01 & - & - & - & - & - \\
\hline 33 & 4 & Volcanic & $\begin{array}{l}\text { Ground Edge } \\
\text { Fragment }\end{array}$ & Broken & 3.52 & - & - & - & - & - \\
\hline 39 & 2 & Quartz & Flake & Right & 1.96 & - & - & - & - & - \\
\hline 39 & 3 & Quartz & Flaked Piece & - & 2.01 & - & - & - & - & - \\
\hline 39 & - & Quartz & Flake & Complete & 0.52 & 8.29 & 9.33 & 3.00 & 0.89 & 55 \\
\hline 39 & - & Crystal Quartz & Flake & Marginal & 0.01 & - & - & - & - & - \\
\hline 40 & 1 & Quartz & Flake & Complete & 1.32 & 8.02 & 16.02 & 6.10 & 0.50 & 53 \\
\hline 42 & 4 & Quartz & Core & Complete & 13.03 & 28.16 & 35.83 & 7.13 & 0.79 & - \\
\hline 42 & - & Crystal Quartz & Flake & Complete & 0.01 & 6.31 & 2.23 & 0.71 & 2.83 & 71 \\
\hline 45 & - & Quartz & Flake & Complete & 1.12 & 18.13 & 8.68 & 5.35 & 2.09 & 58 \\
\hline
\end{tabular}


Appendix I. Field specimen log, Site 3 Mangrove Beach Headland Midden, Square A.

\begin{tabular}{|c|c|c|c|c|c|c|}
\hline FS\# & Square & $\mathbf{X U}$ & Object \# & Description & Date & \# of Bags \\
\hline 1 & $\mathrm{~A}$ & 1 & - & $2.3 \mathrm{~mm}$ sieve residue & $7 / 05 / 2013$ & 3 \\
\hline 2 & $\mathrm{~A}$ & 1 & - & sediment sample & $7 / 05 / 2013$ & 1 \\
\hline 3 & $\mathrm{~A}$ & 1 & 1 & quartz artefact & $7 / 05 / 2013$ & 1 \\
\hline 4 & $\mathrm{~A}$ & 1 & 2 & charcoal & $7 / 05 / 2013$ & 1 \\
\hline 5 & A & 1 & 3 & charcoal & $7 / 05 / 2013$ & 1 \\
\hline 6 & $\mathrm{~A}$ & 1 & 4 & charcoal & $7 / 05 / 2013$ & 1 \\
\hline 7 & $\mathrm{~A}$ & 1 & 5 & charcoal & $7 / 05 / 2013$ & 1 \\
\hline 8 & $\mathrm{~A}$ & 1 & 6 & charcoal & $7 / 05 / 2013$ & 1 \\
\hline 9 & $\mathrm{~A}$ & 1 & 7 & turtle bone & $7 / 05 / 2013$ & 1 \\
\hline 10 & $\mathrm{~A}$ & 2 & - & quartz artefact & $7 / 05 / 2013$ & 3 \\
\hline 11 & $\mathrm{~A}$ & 2 & - & quartz artefact & $7 / 05 / 2013$ & 1 \\
\hline 12 & $\mathrm{~A}$ & 2 & 1 & turtle bone & $7 / 05 / 2013$ & 1 \\
\hline 13 & $\mathrm{~A}$ & 2 & 2 & quartz artefact & $7 / 05 / 2013$ & 1 \\
\hline 14 & $\mathrm{~A}$ & 3 & 3 & quartz artefact & $7 / 05 / 2013$ & 1 \\
\hline 15 & $\mathrm{~A}$ & 3 & - & $2.3 \mathrm{~mm}$ sieve residue & $7 / 05 / 2013$ & 2 \\
\hline 16 & A & 3 & - & sediment sample & $7 / 05 / 2013$ & 1 \\
\hline 17 & $\mathrm{~A}$ & 3 & 1 & quartz artefact & $7 / 05 / 2013$ & 1 \\
\hline 18 & $\mathrm{~A}$ & 3 & 2 & quartz artefact & $7 / 05 / 2013$ & 1 \\
\hline 19 & $\mathrm{~A}$ & 3 & 3 & quartz artefact & $7 / 05 / 2013$ & 1 \\
\hline 20 & $\mathrm{~A}$ & 3 & 4 & charcoal & $7 / 05 / 2013$ & 1 \\
\hline 21 & $\mathrm{~A}$ & 3 & 5 & charcoal & $7 / 05 / 2013$ & 1 \\
\hline 22 & $\mathrm{~A}$ & 3 & 6 & charcoal & $7 / 05 / 2013$ & 1 \\
\hline 23 & $\mathrm{~A}$ & 3 & 7 & quartz artefact & $7 / 05 / 2013$ & 1 \\
\hline 24 & $\mathrm{~A}$ & 3 & 8 & charcoal & $7 / 05 / 2013$ & 1 \\
\hline 25 & $\mathrm{~A}$ & 3 & 9 & charcoal & $7 / 05 / 2013$ & 1 \\
\hline 26 & $\mathrm{~A}$ & 4 & - & $2.3 \mathrm{~mm}$ sieve residue & $7 / 05 / 2013$ & 1 \\
\hline 27 & A & 4 & - & sediment sample & $7 / 05 / 2013$ & 1 \\
\hline 28 & $\mathrm{~A}$ & 5 & - & $2.3 \mathrm{~mm}$ sieve residue & $8 / 05 / 2013$ & 1 \\
\hline 29 & $\mathrm{~A}$ & 5 & - & sediment sample & $8 / 05 / 2013$ & 1 \\
\hline 30 & $\mathrm{~A}$ & 5 & 1 & quartz artefact & $8 / 05 / 2013$ & 1 \\
\hline 31 & $\mathrm{~A}$ & 6 & - & $2.3 \mathrm{~mm}$ sieve residue & $8 / 05 / 2013$ & 1 \\
\hline 32 & $\mathrm{~A}$ & 6 & - & sediment sample & $8 / 05 / 2013$ & 1 \\
\hline 33 & $\mathrm{~A}$ & 6 & 1 & quartz artefact & $8 / 05 / 2013$ & 1 \\
\hline 34 & $\mathrm{~A}$ & 7 & - & $2.3 \mathrm{~mm}$ sieve residue & $8 / 05 / 2013$ & 1 \\
\hline 35 & $\mathrm{~A}$ & 7 & - & sediment sample & $8 / 05 / 2013$ & 1 \\
\hline 36 & $\mathrm{~A}$ & 7 & 1 & quartz artefact & $8 / 05 / 2013$ & 1 \\
\hline 37 & $\mathrm{~A}$ & 7 & 2 & charcoal & $8 / 05 / 2013$ & 1 \\
\hline 38 & $\mathrm{~A}$ & 7 & 3 & charcoal & $8 / 05 / 2013$ & 1 \\
\hline 39 & $\mathrm{~A}$ & 7 & 4 & charcoal & $8 / 05 / 2013$ & 1 \\
\hline 40 & $\mathrm{~A}$ & 7 & 5 & charcoal & $8 / 05 / 2013$ & 1 \\
\hline 41 & $\mathrm{~A}$ & 7 & 6 & charcoal & $8 / 05 / 2013$ & 1 \\
\hline 42 & $\mathrm{~A}$ & 7 & 7 & Conus sp. fragment & $8 / 05 / 2013$ & 1 \\
\hline 43 & A & 7 & 8 & charcoal & $8 / 05 / 2013$ & 1 \\
\hline 44 & $\mathrm{~A}$ & 7 & 9 & quartz artefact & $8 / 05 / 2013$ & 1 \\
\hline 45 & $\mathrm{~A}$ & 7 & 10 & charcoal & $8 / 05 / 2013$ & 1 \\
\hline 46 & $\mathrm{~A}$ & 7 & 11 & charcoal & $8 / 05 / 2013$ & 1 \\
\hline 47 & $\mathrm{~A}$ & 7 & 12 & charcoal & $8 / 05 / 2013$ & 1 \\
\hline 48 & $\mathrm{~A}$ & 7 & 13 & charcoal & $8 / 05 / 2013$ & 1 \\
\hline 49 & $\mathrm{~A}$ & 7 & 14 & charcoal & $8 / 05 / 2013$ & 1 \\
\hline 50 & $\mathrm{~A}$ & 7 & 15 & charcoal & $8 / 05 / 2013$ & 1 \\
\hline 51 & $\mathrm{~A}$ & 7 & 16 & charcoal & $8 / 05 / 2013$ & 1 \\
\hline 52 & A & 8 & - & $2.3 \mathrm{~mm}$ sieve residue & $8 / 05 / 2013$ & 1 \\
\hline
\end{tabular}


Appendix I. Field specimen log, Site 3 Mangrove Beach Headland Midden, Square A (cont.).

\begin{tabular}{|c|c|c|c|c|c|c|}
\hline FS\# & Square & $\mathbf{X U}$ & Object \# & Description & Date & \# of Bags \\
\hline 53 & $\mathrm{~A}$ & 8 & - & sediment sample & $8 / 05 / 2013$ & 1 \\
\hline 54 & A & 8 & 1 & quartz artefact & $8 / 05 / 2013$ & 1 \\
\hline 55 & $\mathrm{~A}$ & 8 & 2 & quartz artefact & $8 / 05 / 2013$ & 1 \\
\hline 56 & A & 8 & 3 & charcoal & $8 / 05 / 2013$ & 1 \\
\hline 57 & A & 8 & 4 & charcoal & $8 / 05 / 2013$ & 1 \\
\hline 58 & A & 8 & 5 & charcoal & $8 / 05 / 2013$ & 1 \\
\hline 59 & A & 8 & 6 & quartz artefact & $8 / 05 / 2013$ & 1 \\
\hline 60 & A & 8 & 7 & rock & $8 / 05 / 2013$ & 1 \\
\hline 61 & A & 9 & - & $2.3 \mathrm{~mm}$ sieve residue & $8 / 05 / 2013$ & 1 \\
\hline 62 & A & 9 & - & sediment sample & $8 / 05 / 2013$ & 1 \\
\hline 63 & A & 9 & 1 & quartz artefact & $8 / 05 / 2013$ & 1 \\
\hline 64 & A & 9 & 2 & quartz artefact & $8 / 05 / 2013$ & 1 \\
\hline 65 & A & 9 & 3 & charcoal & $8 / 05 / 2013$ & 1 \\
\hline 66 & A & 9 & 4 & charcoal & $8 / 05 / 2013$ & 1 \\
\hline 67 & A & 9 & 5 & quartz artefact & $8 / 05 / 2013$ & 1 \\
\hline 68 & A & 9 & 6 & charcoal & $8 / 05 / 2013$ & 1 \\
\hline 69 & A & 9 & 7 & charcoal & $8 / 05 / 2013$ & 1 \\
\hline 70 & A & 9 & 8 & charcoal & $8 / 05 / 2013$ & 1 \\
\hline 71 & A & 9 & 9 & charcoal & $8 / 05 / 2013$ & 1 \\
\hline 72 & A & 9 & 10 & charcoal & $8 / 05 / 2013$ & 1 \\
\hline 73 & $\mathrm{~A}$ & 9 & 11 & charcoal & $8 / 05 / 2013$ & 1 \\
\hline 74 & A & 9 & 12 & quartz artefact & $8 / 05 / 2013$ & 1 \\
\hline 75 & A & 9 & 13 & charcoal & $8 / 05 / 2013$ & 1 \\
\hline 76 & A & 9 & 14 & quartz artefact & $8 / 05 / 2013$ & 1 \\
\hline 77 & A & 9 & 15 & charcoal & $8 / 05 / 2013$ & 1 \\
\hline 78 & A & 9 & 16 & quartz artefact & $8 / 05 / 2013$ & 1 \\
\hline 79 & A & 9 & 17 & charcoal & $8 / 05 / 2013$ & 1 \\
\hline 80 & A & 9 & 18 & charcoal & $8 / 05 / 2013$ & 1 \\
\hline 81 & A & 9 & 19 & charcoal & $8 / 05 / 2013$ & 1 \\
\hline 82 & A & 10 & - & $2.3 \mathrm{~mm}$ sieve residue & $8 / 05 / 2013$ & 1 \\
\hline 83 & A & 10 & - & sediment sample & $8 / 05 / 2013$ & 1 \\
\hline 84 & A & 10 & 1 & charcoal & $8 / 05 / 2013$ & 1 \\
\hline 85 & A & 10 & 2 & charcoal & $8 / 05 / 2013$ & 1 \\
\hline 86 & A & 10 & 3 & quartz artefact & $8 / 05 / 2013$ & 1 \\
\hline 87 & A & 10 & 4 & quartz artefact & $8 / 05 / 2013$ & 1 \\
\hline 88 & A & 10 & 5 & quartz artefact & $8 / 05 / 2013$ & 1 \\
\hline 89 & A & 10 & 6 & quartz artefact & $8 / 05 / 2013$ & 1 \\
\hline 90 & A & 10 & 7 & charcoal & $8 / 05 / 2013$ & 1 \\
\hline 91 & A & 10 & 8 & charcoal & $8 / 05 / 2013$ & 1 \\
\hline 92 & A & 10 & 9 & quartz artefact & $8 / 05 / 2013$ & 1 \\
\hline 93 & A & 10 & 10 & quartz artefact & $8 / 05 / 2013$ & 1 \\
\hline 94 & $\mathrm{~A}$ & 10 & 11 & charcoal & $8 / 05 / 2013$ & 1 \\
\hline 95 & A & 11 & - & $2.3 \mathrm{~mm}$ sieve residue & $9 / 05 / 2013$ & 1 \\
\hline 96 & A & 11 & - & sediment sample & $9 / 05 / 2013$ & 1 \\
\hline 97 & A & 11 & 1 & quartz artefact & $9 / 05 / 2013$ & 1 \\
\hline 98 & A & 11 & 2 & quartz artefact & $9 / 05 / 2013$ & 1 \\
\hline 99 & A & 11 & 3 & quartz artefact & $9 / 05 / 2013$ & 1 \\
\hline 100 & A & 11 & 4 & quartz artefact & $9 / 05 / 2013$ & 1 \\
\hline 101 & A & 11 & 5 & charcoal & $9 / 05 / 2013$ & 1 \\
\hline 102 & A & 11 & 6 & discarded sample (rock) & $9 / 05 / 2013$ & 1 \\
\hline 103 & A & 11 & 7 & charcoal & $9 / 05 / 2013$ & 1 \\
\hline 104 & A & 11 & 8 & pumice & $9 / 05 / 2013$ & 1 \\
\hline
\end{tabular}


Appendix I. Field specimen log, Site 3 Mangrove Beach Headland Midden, Square A (cont.).

\begin{tabular}{|c|c|c|c|c|c|c|}
\hline FS\# & Square & $\mathbf{X U}$ & Object \# & Description & Date & \# of Bags \\
\hline 105 & $\mathrm{~A}$ & 11 & 9 & charcoal & $9 / 05 / 2013$ & 1 \\
\hline 106 & $\mathrm{~A}$ & 11 & 10 & charcoal & $9 / 05 / 2013$ & 1 \\
\hline 107 & $\mathrm{~A}$ & 11 & 11 & charcoal & $9 / 05 / 2013$ & 1 \\
\hline 108 & $\mathrm{~A}$ & 11 & 12 & charcoal & $9 / 05 / 2013$ & 1 \\
\hline 109 & $\mathrm{~A}$ & 11 & 13 & quartz artefact & $9 / 05 / 2013$ & 1 \\
\hline 110 & A & 11 & 14 & charcoal & $9 / 05 / 2013$ & 1 \\
\hline 111 & $\mathrm{~A}$ & 11 & 15 & charcoal & $9 / 05 / 2013$ & 1 \\
\hline 112 & $\mathrm{~A}$ & 11 & 16 & quartz artefact & $9 / 05 / 2013$ & 1 \\
\hline 113 & $\mathrm{~A}$ & 11 & 17 & charcoal & $9 / 05 / 2013$ & 1 \\
\hline 114 & $\mathrm{~A}$ & 11 & 18 & charcoal & $9 / 05 / 2013$ & 1 \\
\hline 115 & A & 11 & 19 & charcoal & $9 / 05 / 2013$ & 1 \\
\hline 116 & $\mathrm{~A}$ & 11 & 20 & charcoal & $9 / 05 / 2013$ & 1 \\
\hline 117 & $\mathrm{~A}$ & 12 & - & $2.3 \mathrm{~mm}$ sieve residue & $9 / 05 / 2013$ & 1 \\
\hline 118 & $\mathrm{~A}$ & 12 & - & sediment sample & $9 / 05 / 2013$ & 1 \\
\hline 119 & $\mathrm{~A}$ & 13 & - & $2.3 \mathrm{~mm}$ sieve residue & $9 / 05 / 2013$ & 1 \\
\hline 120 & $\mathrm{~A}$ & 13 & - & sediment sample & $9 / 05 / 2013$ & 1 \\
\hline 121 & $\mathrm{~A}$ & 14 & - & $2.3 \mathrm{~mm}$ sieve residue & $9 / 05 / 2013$ & 1 \\
\hline 122 & $\mathrm{~A}$ & 14 & - & sediment sample & $9 / 05 / 2013$ & 1 \\
\hline 123 & $\mathrm{~A}$ & 14 & 1 & quartz artefact & $9 / 05 / 2013$ & 1 \\
\hline 124 & $\mathrm{~A}$ & 14 & 2 & charcoal & $9 / 05 / 2013$ & 1 \\
\hline 125 & $\mathrm{~A}$ & 14 & 3 & charcoal & $9 / 05 / 2013$ & 1 \\
\hline 126 & A & 14 & 4 & charcoal & $9 / 05 / 2013$ & 1 \\
\hline 127 & A & 14 & 5 & charcoal & $9 / 05 / 2013$ & 1 \\
\hline 128 & A & 15 & - & $2.3 \mathrm{~mm}$ sieve residue & $9 / 05 / 2013$ & 1 \\
\hline 129 & A & 15 & - & sediment sample & $9 / 05 / 2013$ & 1 \\
\hline 130 & A & 15 & 1 & manuport & $9 / 05 / 2013$ & 1 \\
\hline 131 & $\mathrm{~A}$ & 15 & 2 & quartz artefact & $9 / 05 / 2013$ & 1 \\
\hline 132 & $\mathrm{~A}$ & 16 & - & $2.3 \mathrm{~mm}$ sieve residue & $9 / 05 / 2013$ & 1 \\
\hline 133 & $\mathrm{~A}$ & 16 & - & sediment sample & $9 / 05 / 2013$ & 1 \\
\hline 134 & $\mathrm{~A}$ & 16 & 1 & charcoal & $9 / 05 / 2013$ & 1 \\
\hline 135 & $\mathrm{~A}$ & 16 & 2 & charcoal & $9 / 05 / 2013$ & 1 \\
\hline 136 & $\mathrm{~A}$ & 17 & - & $2.3 \mathrm{~mm}$ sieve residue & $10 / 05 / 2013$ & 1 \\
\hline 137 & A & 17 & - & sediment sample & $10 / 05 / 2013$ & 1 \\
\hline 138 & A & 17 & 1 & charcoal & $10 / 05 / 2013$ & 1 \\
\hline 139 & $\mathrm{~A}$ & 17 & 2 & charcoal & $10 / 05 / 2013$ & 1 \\
\hline 140 & $\mathrm{~A}$ & 17 & 3 & charcoal & $10 / 05 / 2013$ & 1 \\
\hline 141 & $\mathrm{~A}$ & 17 & 4 & charcoal & $10 / 05 / 2013$ & 1 \\
\hline 142 & A & 18 & - & $2.3 \mathrm{~mm}$ sieve residue & $10 / 05 / 2013$ & 1 \\
\hline 143 & A & 18 & - & sediment sample & $10 / 05 / 2013$ & 1 \\
\hline 144 & $\mathrm{~A}$ & 18 & 1 & sediment collected in situ & $10 / 05 / 2013$ & 1 \\
\hline 145 & $\mathrm{~A}$ & 18 & 2 & sediment collected in situ & $10 / 05 / 2013$ & 1 \\
\hline 146 & $\mathrm{~A}$ & 19 & - & $2.3 \mathrm{~mm}$ sieve residue & $10 / 05 / 2013$ & 1 \\
\hline 147 & $\mathrm{~A}$ & 19 & - & sediment sample & $10 / 05 / 2013$ & 1 \\
\hline 148 & A & 19 & 1 & charcoal & $10 / 05 / 2013$ & 1 \\
\hline 149 & $\mathrm{~A}$ & 19 & 2 & quartz artefact & $10 / 05 / 2013$ & 1 \\
\hline 150 & $\mathrm{~A}$ & 19 & 3 & charcoal & $10 / 05 / 2013$ & 1 \\
\hline 151 & $\mathrm{~A}$ & 19 & 4 & charcoal & $10 / 05 / 2013$ & 1 \\
\hline 152 & $\mathrm{~A}$ & 19 & 5 & charcoal & $10 / 05 / 2013$ & 1 \\
\hline 153 & $\mathrm{~A}$ & 19 & 6 & charcoal & $10 / 05 / 2013$ & 1 \\
\hline 154 & $\mathrm{~A}$ & 19 & 7 & charcoal & $10 / 05 / 2013$ & 1 \\
\hline 155 & $\mathrm{~A}$ & 19 & 8 & quartz artefact & $10 / 05 / 2013$ & 1 \\
\hline 156 & A & 19 & 9 & charcoal & $10 / 05 / 2013$ & 1 \\
\hline
\end{tabular}


Appendix I. Field specimen log, Site 3 Mangrove Beach Headland Midden, Square A (cont.).

\begin{tabular}{|c|c|c|c|c|c|c|}
\hline FS\# & Square & $\mathbf{X U}$ & Object \# & Description & Date & \# of Bags \\
\hline 157 & A & 20 & - & $2.3 \mathrm{~mm}$ sieve residue & $10 / 05 / 2013$ & 1 \\
\hline 158 & $\mathrm{~A}$ & 20 & - & sediment sample & $10 / 05 / 2013$ & 1 \\
\hline 159 & A & 20 & 1 & charcoal & $10 / 05 / 2013$ & 1 \\
\hline 160 & A & 20 & 2 & charcoal & $10 / 05 / 2013$ & 1 \\
\hline 161 & $\mathrm{~A}$ & 20 & 3 & charcoal & $10 / 05 / 2013$ & 1 \\
\hline 162 & A & 20 & 4 & charcoal & $10 / 05 / 2013$ & 1 \\
\hline 163 & A & 20 & 5 & charcoal & $10 / 05 / 2013$ & 1 \\
\hline 164 & A & 20 & 6 & charcoal & $10 / 05 / 2013$ & 1 \\
\hline 165 & $\mathrm{~A}$ & 20 & 7 & charcoal & $10 / 05 / 2013$ & 1 \\
\hline 166 & $\mathrm{~A}$ & 20 & 8 & charcoal & $10 / 05 / 2013$ & 1 \\
\hline 167 & A & 20 & 9 & charcoal & $10 / 05 / 2013$ & 1 \\
\hline 168 & $\mathrm{~A}$ & 20 & 10 & charcoal & $10 / 05 / 2013$ & 1 \\
\hline 169 & A & 20 & 11 & charcoal & $10 / 05 / 2013$ & 1 \\
\hline 170 & A & 20 & 12 & charcoal & $10 / 05 / 2013$ & 1 \\
\hline 171 & A & 20 & 13 & charcoal & $10 / 05 / 2013$ & 1 \\
\hline 172 & A & 20 & 14 & charcoal & $10 / 05 / 2013$ & 1 \\
\hline 173 & $\mathrm{~A}$ & 20 & 15 & charcoal & $10 / 05 / 2013$ & 1 \\
\hline 174 & A & 20 & 16 & charcoal & $10 / 05 / 2013$ & 1 \\
\hline 175 & A & 20 & 17 & charcoal & $10 / 05 / 2013$ & 1 \\
\hline 176 & A & 20 & 18 & charcoal & $10 / 05 / 2013$ & 1 \\
\hline 177 & $\mathrm{~A}$ & 21 & - & $2.3 \mathrm{~mm}$ sieve residue & $10 / 05 / 2013$ & 1 \\
\hline 178 & A & 21 & - & sediment sample & $10 / 05 / 2013$ & 1 \\
\hline 179 & A & 21 & 1 & rock & $10 / 05 / 2013$ & 1 \\
\hline 180 & A & 21 & 2 & charcoal & $10 / 05 / 2013$ & 1 \\
\hline 181 & A & 22 & - & $2.3 \mathrm{~mm}$ sieve residue & $11 / 05 / 2013$ & 1 \\
\hline 182 & A & 22 & - & sediment sample & $11 / 05 / 2013$ & 1 \\
\hline 183 & $\mathrm{~A}$ & 22 & 1 & charcoal & $11 / 05 / 2013$ & 1 \\
\hline 184 & $\mathrm{~A}$ & 22 & 2 & charcoal & $11 / 05 / 2013$ & 1 \\
\hline 185 & $\mathrm{~A}$ & 22 & 3 & charcoal & $11 / 05 / 2013$ & 1 \\
\hline 186 & A & 22 & 4 & charcoal & $11 / 05 / 2013$ & 1 \\
\hline 187 & $\mathrm{~A}$ & 22 & 5 & charcoal & $11 / 05 / 2013$ & 1 \\
\hline 188 & A & 22 & 6 & charcoal & $11 / 05 / 2013$ & 1 \\
\hline 189 & A & 22 & 7 & charcoal & $11 / 05 / 2013$ & 1 \\
\hline 190 & $\mathrm{~A}$ & 22 & 8 & charcoal & $11 / 05 / 2013$ & 1 \\
\hline 191 & A & 22 & 9 & charcoal & $11 / 05 / 2013$ & 1 \\
\hline 192 & $\mathrm{~A}$ & 22 & 10 & quartz artefact & $11 / 05 / 2013$ & 1 \\
\hline 193 & $\mathrm{~A}$ & 22 & 11 & quartz artefact & $11 / 05 / 2013$ & 1 \\
\hline 194 & A & 22 & 12 & charcoal & $11 / 05 / 2013$ & 1 \\
\hline 195 & $\mathrm{~A}$ & 22 & 13 & charcoal & $11 / 05 / 2013$ & 1 \\
\hline 196 & $\mathrm{~A}$ & 22 & 14 & charcoal & $11 / 05 / 2013$ & 1 \\
\hline 197 & A & 22 & 15 & charcoal & $11 / 05 / 2013$ & 1 \\
\hline 198 & $\mathrm{~A}$ & 22 & 16 & charcoal & $11 / 05 / 2013$ & 1 \\
\hline 199 & A & 22 & 17 & charcoal & $11 / 05 / 2013$ & 1 \\
\hline 200 & $\mathrm{~A}$ & 22 & 18 & charcoal & $11 / 05 / 2013$ & 1 \\
\hline 201 & A & 22 & 19 & charcoal & $11 / 05 / 2013$ & 1 \\
\hline 202 & $\mathrm{~A}$ & 22 & 20 & charcoal & $11 / 05 / 2013$ & 1 \\
\hline 203 & A & 22 & 21 & charcoal & $11 / 05 / 2013$ & 1 \\
\hline 204 & $\mathrm{~A}$ & 22 & 22 & charcoal & $11 / 05 / 2013$ & 1 \\
\hline 205 & A & 22 & 23 & manuport & $11 / 05 / 2013$ & 1 \\
\hline 206 & $\mathrm{~A}$ & 22 & 24 & charcoal & $11 / 05 / 2013$ & 1 \\
\hline 207 & $\mathrm{~A}$ & 23 & - & $2.3 \mathrm{~mm}$ sieve residue & $11 / 05 / 2013$ & 1 \\
\hline 208 & A & 23 & - & sediment sample & $11 / 05 / 2013$ & 1 \\
\hline
\end{tabular}


Appendix I. Field specimen log, Site 3 Mangrove Beach Headland Midden, Square A (cont.).

\begin{tabular}{|c|c|c|c|c|c|c|}
\hline FS\# & Square & $\mathbf{X U}$ & Object \# & Description & Date & \# of Bags \\
\hline 209 & $\mathrm{~A}$ & 23 & 1 & quartz artefact & $11 / 05 / 2013$ & 1 \\
\hline 210 & $\mathrm{~A}$ & 23 & 2 & red ochre & $11 / 05 / 2013$ & 1 \\
\hline 211 & $\mathrm{~A}$ & 23 & 3 & charcoal & $11 / 05 / 2013$ & 1 \\
\hline 212 & A & 23 & 4 & charcoal & $11 / 05 / 2013$ & 1 \\
\hline 213 & $\mathrm{~A}$ & 23 & 5 & charcoal & $11 / 05 / 2013$ & 1 \\
\hline 214 & A & 23 & 6 & charcoal & $11 / 05 / 2013$ & 1 \\
\hline 215 & $\mathrm{~A}$ & 23 & 7 & charcoal & $11 / 05 / 2013$ & 1 \\
\hline 216 & $\mathrm{~A}$ & 23 & 8 & charcoal & $11 / 05 / 2013$ & 1 \\
\hline 217 & A & 23 & 9 & charcoal & $11 / 05 / 2013$ & 1 \\
\hline 218 & $\mathrm{~A}$ & 23 & 10 & charcoal & $11 / 05 / 2013$ & 1 \\
\hline 219 & A & 23 & 11 & charcoal & $11 / 05 / 2013$ & 1 \\
\hline 220 & $\mathrm{~A}$ & 23 & 12 & charcoal & $11 / 05 / 2013$ & 1 \\
\hline 221 & $\mathrm{~A}$ & 23 & 13 & charcoal & $11 / 05 / 2013$ & 1 \\
\hline 222 & $\mathrm{~A}$ & 23 & 14 & red ochre & $11 / 05 / 2013$ & 1 \\
\hline 223 & $\mathrm{~A}$ & 23 & 15 & mollusc fragment & $11 / 05 / 2013$ & 1 \\
\hline 224 & $\mathrm{~A}$ & 23 & 16 & charcoal & $11 / 05 / 2013$ & 1 \\
\hline 225 & $\mathrm{~A}$ & 23 & 17 & charcoal & $11 / 05 / 2013$ & 1 \\
\hline 226 & $\mathrm{~A}$ & 23 & 18 & charcoal & $11 / 05 / 2013$ & 1 \\
\hline 227 & $\mathrm{~A}$ & 23 & 19 & quartz artefact & $11 / 05 / 2013$ & 1 \\
\hline 228 & $\mathrm{~A}$ & 23 & 20 & quartz artefact & $11 / 05 / 2013$ & 1 \\
\hline 229 & $\mathrm{~A}$ & 23 & 21 & charcoal & $11 / 05 / 2013$ & 1 \\
\hline 230 & A & 23 & 22 & red ochre & $11 / 05 / 2013$ & 1 \\
\hline 231 & A & 23 & 23 & charcoal & $11 / 05 / 2013$ & 1 \\
\hline 232 & A & 23 & 24 & charcoal & $11 / 05 / 2013$ & 1 \\
\hline 233 & $\mathrm{~A}$ & 23 & 25 & charcoal & $11 / 05 / 2013$ & 1 \\
\hline 234 & A & 23 & 26 & charcoal & $11 / 05 / 2013$ & 1 \\
\hline 235 & $\mathrm{~A}$ & 23 & 27 & charcoal & $11 / 05 / 2013$ & 1 \\
\hline 236 & $\mathrm{~A}$ & 23 & 28 & charcoal & $11 / 05 / 2013$ & 1 \\
\hline 237 & $\mathrm{~A}$ & 23 & 29 & charcoal & $11 / 05 / 2013$ & 1 \\
\hline 238 & $\mathrm{~A}$ & 23 & 30 & charcoal & $11 / 05 / 2013$ & 1 \\
\hline 239 & $\mathrm{~A}$ & 23 & 31 & charcoal & $11 / 05 / 2013$ & 1 \\
\hline 240 & $\mathrm{~A}$ & 23 & 32 & quartz artefact & $11 / 05 / 2013$ & 1 \\
\hline 241 & A & 23 & 33 & sedimentary artefact & $11 / 05 / 2013$ & 1 \\
\hline 242 & A & 23 & 34 & charcoal & $11 / 05 / 2013$ & 1 \\
\hline 243 & $\mathrm{~A}$ & 23 & 35 & mollusc fragment & $11 / 05 / 2013$ & 1 \\
\hline 244 & $\mathrm{~A}$ & 23 & 36 & charcoal & $11 / 05 / 2013$ & 1 \\
\hline 245 & $\mathrm{~A}$ & 23 & 37 & charcoal & $11 / 05 / 2013$ & 1 \\
\hline 246 & A & 23 & 38 & charcoal & $11 / 05 / 2013$ & 1 \\
\hline 247 & A & 23 & 39 & heat retainer? & $11 / 05 / 2013$ & 1 \\
\hline 248 & $\mathrm{~A}$ & 23 & 40 & charcoal & $11 / 05 / 2013$ & 1 \\
\hline 249 & $\mathrm{~A}$ & 23 & 41 & quartz artefact & $11 / 05 / 2013$ & 1 \\
\hline 250 & $\mathrm{~A}$ & 23 & 42 & heat retainer? & $11 / 05 / 2013$ & 1 \\
\hline 251 & $\mathrm{~A}$ & 23 & 43 & heat retainer? & $11 / 05 / 2013$ & 1 \\
\hline 252 & A & 23 & 44 & charcoal & $11 / 05 / 2013$ & 1 \\
\hline 253 & $\mathrm{~A}$ & 23 & 45 & charcoal & $11 / 05 / 2013$ & 1 \\
\hline 254 & $\mathrm{~A}$ & 24 & - & $2.3 \mathrm{~mm}$ sieve residue & $13 / 05 / 2013$ & 1 \\
\hline 255 & $\mathrm{~A}$ & 24 & - & sediment sample & $13 / 05 / 2013$ & 1 \\
\hline 256 & $\mathrm{~A}$ & 24 & 1 & heat retainer? & $13 / 05 / 2013$ & 1 \\
\hline 257 & $\mathrm{~A}$ & 24 & 2 & charcoal & $13 / 05 / 2013$ & 1 \\
\hline 258 & $\mathrm{~A}$ & 24 & 3 & charcoal & $13 / 05 / 2013$ & 1 \\
\hline 259 & $\mathrm{~A}$ & 24 & 4 & charcoal & $13 / 05 / 2013$ & 1 \\
\hline 260 & A & 24 & 5 & quartz artefact & $13 / 05 / 2013$ & 1 \\
\hline
\end{tabular}


Appendix I. Field specimen log, Site 3 Mangrove Beach Headland Midden, Square A (cont.).

\begin{tabular}{|c|c|c|c|c|c|c|}
\hline FS\# & Square & $\mathbf{X U}$ & Object \# & Description & Date & \# of Bags \\
\hline 261 & A & 24 & 6 & charcoal & $13 / 05 / 2013$ & 1 \\
\hline 262 & $\mathrm{~A}$ & 24 & 7 & charcoal & $13 / 05 / 2013$ & 1 \\
\hline 263 & $\mathrm{~A}$ & 24 & 8 & charcoal & $13 / 05 / 2013$ & 1 \\
\hline 264 & $\mathrm{~A}$ & 24 & 9 & charcoal & $13 / 05 / 2013$ & 1 \\
\hline 265 & A & 24 & 10 & charcoal & $13 / 05 / 2013$ & 1 \\
\hline 266 & $\mathrm{~A}$ & 24 & 11 & charcoal & $13 / 05 / 2013$ & 1 \\
\hline 267 & $\mathrm{~A}$ & 24 & 12 & charcoal & $13 / 05 / 2013$ & 1 \\
\hline 268 & $\mathrm{~A}$ & 24 & 13 & quartz artefact & $13 / 05 / 2013$ & 1 \\
\hline 269 & A & 24 & 14 & quartz artefact & $13 / 05 / 2013$ & 1 \\
\hline 270 & A & 24 & 15 & quartz artefact & $13 / 05 / 2013$ & 1 \\
\hline 271 & A & 24 & 16 & charcoal & $13 / 05 / 2013$ & 1 \\
\hline 272 & $\mathrm{~A}$ & 24 & 17 & charcoal & $13 / 05 / 2013$ & 1 \\
\hline 273 & $\mathrm{~A}$ & 24 & 18 & charcoal & $13 / 05 / 2013$ & 1 \\
\hline 274 & $\mathrm{~A}$ & 24 & 19 & charcoal & $13 / 05 / 2013$ & 1 \\
\hline 275 & A & 24 & 20 & charcoal & $13 / 05 / 2013$ & 1 \\
\hline 276 & $\mathrm{~A}$ & 24 & 21 & charcoal & $13 / 05 / 2013$ & 1 \\
\hline 277 & A & 24 & 22 & charcoal & $13 / 05 / 2013$ & 1 \\
\hline 278 & $\mathrm{~A}$ & 24 & 23 & charcoal & $13 / 05 / 2013$ & 1 \\
\hline 279 & $\mathrm{~A}$ & 24 & 24 & charcoal & $13 / 05 / 2013$ & 1 \\
\hline 280 & $\mathrm{~A}$ & 24 & 25 & charcoal & $13 / 05 / 2013$ & 1 \\
\hline 281 & $\mathrm{~A}$ & 24 & 26 & charcoal & $13 / 05 / 2013$ & 1 \\
\hline 282 & A & 24 & 27 & charcoal & $13 / 05 / 2013$ & 1 \\
\hline 283 & A & 24 & 28 & charcoal & $13 / 05 / 2013$ & 1 \\
\hline 284 & $\mathrm{~A}$ & 24 & 29 & charcoal & $13 / 05 / 2013$ & 1 \\
\hline 285 & $\mathrm{~A}$ & 24 & 30 & charcoal & $13 / 05 / 2013$ & 1 \\
\hline 286 & $\mathrm{~A}$ & 24 & 31 & charcoal & $13 / 05 / 2013$ & 1 \\
\hline 287 & $\mathrm{~A}$ & 24 & 32 & charcoal & $13 / 05 / 2013$ & 1 \\
\hline 288 & $\mathrm{~A}$ & 24 & 33 & charcoal & $13 / 05 / 2013$ & 1 \\
\hline 289 & $\mathrm{~A}$ & 24 & 34 & charcoal & $13 / 05 / 2013$ & 1 \\
\hline 290 & $\mathrm{~A}$ & 24 & 35 & charcoal & $13 / 05 / 2013$ & 1 \\
\hline 291 & $\mathrm{~A}$ & 24 & 36 & charcoal & $13 / 05 / 2013$ & 1 \\
\hline 292 & $\mathrm{~A}$ & 24 & 37 & charcoal & $13 / 05 / 2013$ & 1 \\
\hline 293 & $\mathrm{~A}$ & 24 & 38 & charcoal & $13 / 05 / 2013$ & 1 \\
\hline 294 & $\mathrm{~A}$ & 24 & 39 & charcoal & $13 / 05 / 2013$ & 1 \\
\hline 295 & $\mathrm{~A}$ & 24 & 40 & charcoal & $13 / 05 / 2013$ & 1 \\
\hline 296 & A & 24 & 41 & charcoal & $13 / 05 / 2013$ & 1 \\
\hline 297 & $\mathrm{~A}$ & 24 & 42 & charcoal & $13 / 05 / 2013$ & 1 \\
\hline 298 & $\mathrm{~A}$ & 24 & 43 & charcoal & $13 / 05 / 2013$ & 1 \\
\hline 299 & $\mathrm{~A}$ & 24 & 44 & charcoal & $13 / 05 / 2013$ & 1 \\
\hline 300 & $\mathrm{~A}$ & 24 & 45 & charcoal & $13 / 05 / 2013$ & 1 \\
\hline 301 & $\mathrm{~A}$ & 24 & 46 & charcoal & $13 / 05 / 2013$ & 1 \\
\hline 302 & $\mathrm{~A}$ & 24 & 47 & charcoal & $13 / 05 / 2013$ & 1 \\
\hline 303 & $\mathrm{~A}$ & 24 & 48 & charcoal & $13 / 05 / 2013$ & 1 \\
\hline 304 & $\mathrm{~A}$ & 24 & 49 & charcoal & $13 / 05 / 2013$ & 1 \\
\hline 305 & A & 24 & 50 & charcoal & $13 / 05 / 2013$ & 1 \\
\hline 306 & $\mathrm{~A}$ & 24 & 51 & charcoal & $13 / 05 / 2013$ & 1 \\
\hline 307 & $\mathrm{~A}$ & 24 & 52 & charcoal & $13 / 05 / 2013$ & 1 \\
\hline 308 & $\mathrm{~A}$ & 24 & 53 & charcoal & $13 / 05 / 2013$ & 1 \\
\hline 309 & $\mathrm{~A}$ & 24 & 54 & charcoal & $13 / 05 / 2013$ & 1 \\
\hline 310 & $\mathrm{~A}$ & 24 & 55 & charcoal & $13 / 05 / 2013$ & 1 \\
\hline 311 & $\mathrm{~A}$ & 24 & 56 & charcoal & $13 / 05 / 2013$ & 1 \\
\hline 312 & $\mathrm{~A}$ & 24 & 57 & quartz artefact & $13 / 05 / 2013$ & 1 \\
\hline
\end{tabular}


Appendix I. Field specimen log, Site 3 Mangrove Beach Headland Midden, Square A (cont.).

\begin{tabular}{|c|c|c|c|c|c|c|}
\hline FS\# & Square & $\mathbf{X U}$ & Object \# & Description & Date & \# of Bags \\
\hline 313 & $\mathrm{~A}$ & 24 & 58 & charcoal & $13 / 05 / 2013$ & 1 \\
\hline 314 & $\mathrm{~A}$ & 24 & 59 & charcoal & $13 / 05 / 2013$ & 1 \\
\hline 315 & $\mathrm{~A}$ & 24 & 60 & charcoal & $13 / 05 / 2013$ & 1 \\
\hline 316 & $\mathrm{~A}$ & 24 & 61 & charcoal & $13 / 05 / 2013$ & 1 \\
\hline 317 & A & 24 & 62 & charcoal & $13 / 05 / 2013$ & 1 \\
\hline 318 & $\mathrm{~A}$ & 24 & 63 & fish tooth & $13 / 05 / 2013$ & 1 \\
\hline 319 & $\mathrm{~A}$ & 24 & 64 & charcoal & $13 / 05 / 2013$ & 1 \\
\hline 320 & $\mathrm{~A}$ & 24 & 65 & charcoal & $13 / 05 / 2013$ & 1 \\
\hline 321 & $\mathrm{~A}$ & 24 & 66 & charcoal & $13 / 05 / 2013$ & 1 \\
\hline 322 & $\mathrm{~A}$ & 25 & 1 & charcoal & $14 / 05 / 2013$ & 1 \\
\hline 323 & $\mathrm{~A}$ & 25 & 2 & charcoal & $14 / 05 / 2013$ & 1 \\
\hline 324 & A & 25 & 3 & charcoal & $14 / 05 / 2013$ & 1 \\
\hline 325 & A & 25 & 4 & charcoal & $14 / 05 / 2013$ & 1 \\
\hline 326 & A & 25 & 5 & charcoal & $14 / 05 / 2013$ & 1 \\
\hline 327 & $\mathrm{~A}$ & 25 & 6 & charcoal & $14 / 05 / 2013$ & 1 \\
\hline 328 & A & 25 & 7 & charcoal & $14 / 05 / 2013$ & 1 \\
\hline 329 & $\mathrm{~A}$ & 25 & 8 & charcoal & $14 / 05 / 2013$ & 1 \\
\hline 330 & $\mathrm{~A}$ & 25 & 9 & charcoal & $14 / 05 / 2013$ & 1 \\
\hline 331 & $\mathrm{~A}$ & 25 & 10 & heat retainer? & $14 / 05 / 2013$ & 1 \\
\hline 332 & $\mathrm{~A}$ & 25 & 11 & charcoal & $14 / 05 / 2013$ & 1 \\
\hline 333 & $\mathrm{~A}$ & 25 & - & $2.3 \mathrm{~mm}$ sieve residue & $14 / 05 / 2013$ & 1 \\
\hline 334 & $\mathrm{~A}$ & 25 & - & sediment sample & $14 / 05 / 2013$ & 1 \\
\hline 335 & $\mathrm{~A}$ & 25 & 12 & charcoal & $14 / 05 / 2013$ & 1 \\
\hline 336 & $\mathrm{~A}$ & 25 & 13 & quartz artefact & $14 / 05 / 2013$ & 1 \\
\hline 337 & $\mathrm{~A}$ & 26 & - & $2.3 \mathrm{~mm}$ sieve residue & $14 / 05 / 2013$ & 1 \\
\hline 338 & $\mathrm{~A}$ & 26 & - & sediment sample & $14 / 05 / 2013$ & 1 \\
\hline 339 & A & 26 & 1 & charcoal & $14 / 05 / 2013$ & 1 \\
\hline 340 & $\mathrm{~A}$ & 26 & 2 & charcoal & $14 / 05 / 2013$ & 1 \\
\hline 341 & $\mathrm{~A}$ & 26 & 3 & charcoal & $14 / 05 / 2013$ & 1 \\
\hline 342 & $\mathrm{~A}$ & 26 & 4 & charcoal & $14 / 05 / 2013$ & 1 \\
\hline 343 & $\mathrm{~A}$ & 26 & 5 & charcoal & $14 / 05 / 2013$ & 1 \\
\hline 344 & A & 26 & 6 & charcoal & $14 / 05 / 2013$ & 1 \\
\hline 345 & $\mathrm{~A}$ & 26 & 7 & charcoal & $14 / 05 / 2013$ & 1 \\
\hline 346 & $\mathrm{~A}$ & 26 & 8 & charcoal & $14 / 05 / 2013$ & 1 \\
\hline 347 & A & 26 & 9 & charcoal & $14 / 05 / 2013$ & 1 \\
\hline 348 & $\mathrm{~A}$ & 26 & 10 & charcoal & $14 / 05 / 2013$ & 1 \\
\hline 349 & $\mathrm{~A}$ & 26 & 11 & charcoal & $14 / 05 / 2013$ & 1 \\
\hline 350 & $\mathrm{~A}$ & 26 & 12 & charcoal & $14 / 05 / 2013$ & 1 \\
\hline 351 & $\mathrm{~A}$ & 26 & 13 & quartz artefact & $14 / 05 / 2013$ & 1 \\
\hline 352 & $\mathrm{~A}$ & 26 & 14 & charcoal & $14 / 05 / 2013$ & 1 \\
\hline 353 & $\mathrm{~A}$ & 26 & 15 & charcoal & $14 / 05 / 2013$ & 1 \\
\hline 354 & $\mathrm{~A}$ & 26 & 16 & charcoal & $14 / 05 / 2013$ & 1 \\
\hline 355 & A & 26 & 17 & charcoal & $14 / 05 / 2013$ & 1 \\
\hline 356 & A & 26 & 18 & charcoal & $14 / 05 / 2013$ & 1 \\
\hline 357 & $\mathrm{~A}$ & 26 & 19 & charcoal & $14 / 05 / 2013$ & 1 \\
\hline 358 & $\mathrm{~A}$ & 26 & 20 & charcoal & $14 / 05 / 2013$ & 1 \\
\hline 359 & $\mathrm{~A}$ & 27 & - & $2.3 \mathrm{~mm}$ sieve residue & $14 / 05 / 2013$ & 1 \\
\hline 360 & $\mathrm{~A}$ & 27 & - & sediment sample & $14 / 05 / 2013$ & 1 \\
\hline 361 & $\mathrm{~A}$ & 27 & 1 & charcoal & $14 / 05 / 2013$ & 1 \\
\hline 362 & $\mathrm{~A}$ & 27 & 2 & charcoal & $14 / 05 / 2013$ & 1 \\
\hline 363 & $\mathrm{~A}$ & 28 & - & $2.3 \mathrm{~mm}$ sieve residue & $15 / 05 / 2013$ & 1 \\
\hline 364 & A & 28 & - & sediment sample & $15 / 05 / 2013$ & 1 \\
\hline
\end{tabular}


Appendix I. Field specimen log, Site 3 Mangrove Beach Headland Midden, Square A (cont.).

\begin{tabular}{|c|c|c|c|c|c|c|}
\hline FS\# & Square & $\mathbf{X U}$ & Object \# & Description & Date & \# of Bags \\
\hline 365 & $\mathrm{~A}$ & 28 & 1 & charcoal & $15 / 05 / 2013$ & 1 \\
\hline 366 & $\mathrm{~A}$ & 28 & 2 & charcoal & $15 / 05 / 2013$ & 1 \\
\hline 367 & $\mathrm{~A}$ & 28 & 3 & quartz artefact & $15 / 05 / 2013$ & 1 \\
\hline 368 & $\mathrm{~A}$ & 28 & 4 & charcoal & $15 / 05 / 2013$ & 1 \\
\hline 369 & A & 28 & 5 & charcoal & $15 / 05 / 2013$ & 1 \\
\hline 370 & $\mathrm{~A}$ & 28 & 6 & mollusc fragment & $15 / 05 / 2013$ & 1 \\
\hline 371 & A & 28 & 7 & charcoal & $15 / 05 / 2013$ & 1 \\
\hline 372 & $\mathrm{~A}$ & 29 & - & $2.3 \mathrm{~mm}$ sieve residue & $15 / 05 / 2013$ & 1 \\
\hline 373 & $\mathrm{~A}$ & 29 & - & sediment sample & $15 / 05 / 2013$ & 1 \\
\hline 374 & $\mathrm{~A}$ & 29 & 1 & charcoal & $15 / 05 / 2013$ & 1 \\
\hline 375 & A & 29 & 2 & charcoal & $15 / 05 / 2013$ & 1 \\
\hline 376 & $\mathrm{~A}$ & 29 & 3 & charcoal & $15 / 05 / 2013$ & 1 \\
\hline 377 & $\mathrm{~A}$ & 29 & 4 & charcoal & $15 / 05 / 2013$ & 1 \\
\hline 378 & $\mathrm{~A}$ & 29 & 5 & charcoal & $15 / 05 / 2013$ & 1 \\
\hline 379 & A & 29 & 6 & charcoal & $15 / 05 / 2013$ & 1 \\
\hline 380 & $\mathrm{~A}$ & 29 & 7 & charcoal & $15 / 05 / 2013$ & 1 \\
\hline 381 & $\mathrm{~A}$ & 29 & 8 & quartz artefact & $15 / 05 / 2013$ & 1 \\
\hline 382 & $\mathrm{~A}$ & 30 & - & $2.3 \mathrm{~mm}$ sieve residue & $15 / 05 / 2013$ & 1 \\
\hline 383 & $\mathrm{~A}$ & 30 & - & sediment sample & $15 / 05 / 2013$ & 1 \\
\hline 384 & $\mathrm{~A}$ & 30 & 1 & charcoal & $15 / 05 / 2013$ & 1 \\
\hline 385 & $\mathrm{~A}$ & 30 & 2 & charcoal & $15 / 05 / 2013$ & 1 \\
\hline 386 & $\mathrm{~A}$ & 30 & 3 & charcoal & $15 / 05 / 2013$ & 1 \\
\hline 387 & $\mathrm{~A}$ & 30 & 4 & mollusc fragment & $15 / 05 / 2013$ & 1 \\
\hline 388 & $\mathrm{~A}$ & 30 & 5 & charcoal & $15 / 05 / 2013$ & 1 \\
\hline 389 & A & 30 & 6 & quartz artefact & $15 / 05 / 2013$ & 1 \\
\hline 390 & A & 30 & 7 & charcoal & $15 / 05 / 2013$ & 1 \\
\hline 391 & $\mathrm{~A}$ & 30 & 8 & charcoal & $15 / 05 / 2013$ & 1 \\
\hline 392 & $\mathrm{~A}$ & 30 & 9 & charcoal & $15 / 05 / 2013$ & 1 \\
\hline 393 & $\mathrm{~A}$ & 30 & 10 & charcoal & $15 / 05 / 2013$ & 1 \\
\hline 394 & $\mathrm{~A}$ & 30 & 11 & charcoal & $15 / 05 / 2013$ & 1 \\
\hline 395 & $\mathrm{~A}$ & 31 & - & $2.3 \mathrm{~mm}$ sieve residue & $16 / 05 / 2013$ & 1 \\
\hline 396 & A & 31 & - & sediment sample & $16 / 05 / 2013$ & 1 \\
\hline 397 & A & 31 & 1 & charcoal & $16 / 05 / 2013$ & 1 \\
\hline 398 & A & 31 & 2 & charcoal & $16 / 05 / 2013$ & 1 \\
\hline 399 & A & 31 & 3 & charcoal & $16 / 05 / 2013$ & 1 \\
\hline 400 & $\mathrm{~A}$ & 31 & 4 & charcoal & $16 / 05 / 2013$ & 1 \\
\hline 401 & $\mathrm{~A}$ & 31 & 5 & charcoal & $16 / 05 / 2013$ & 1 \\
\hline 402 & $\mathrm{~A}$ & 32 & - & $2.3 \mathrm{~mm}$ sieve residue & $16 / 05 / 2013$ & 1 \\
\hline 403 & $\mathrm{~A}$ & 32 & - & sediment sample & $16 / 05 / 2013$ & 1 \\
\hline 404 & A & 32 & 1 & charcoal & $16 / 05 / 2013$ & 1 \\
\hline 405 & $\mathrm{~A}$ & 32 & 2 & charcoal & $16 / 05 / 2013$ & 1 \\
\hline 406 & $\mathrm{~A}$ & 32 & 3 & charcoal & $16 / 05 / 2013$ & 1 \\
\hline 407 & $\mathrm{~A}$ & 32 & 4 & charcoal & $16 / 05 / 2013$ & 1 \\
\hline 408 & $\mathrm{~A}$ & 32 & 5 & charcoal & $16 / 05 / 2013$ & 1 \\
\hline 409 & A & 32 & 6 & charcoal & $16 / 05 / 2013$ & 1 \\
\hline 410 & $\mathrm{~A}$ & 32 & 7 & charcoal & $16 / 05 / 2013$ & 1 \\
\hline 411 & $\mathrm{~A}$ & 32 & 8 & charcoal & $16 / 05 / 2013$ & 1 \\
\hline 412 & $\mathrm{~A}$ & 32 & 9 & charcoal & $16 / 05 / 2013$ & 1 \\
\hline 413 & $\mathrm{~A}$ & 32 & 10 & charcoal & $16 / 05 / 2013$ & 1 \\
\hline 414 & $\mathrm{~A}$ & 32 & 11 & charcoal & $16 / 05 / 2013$ & 1 \\
\hline 415 & $\mathrm{~A}$ & 32 & 12 & charcoal & $16 / 05 / 2013$ & 1 \\
\hline 416 & $\mathrm{~A}$ & 32 & 13 & charcoal & $16 / 05 / 2013$ & 1 \\
\hline
\end{tabular}


Appendix I. Field specimen log, Site 3 Mangrove Beach Headland Midden, Square A (cont.).

\begin{tabular}{|c|c|c|c|c|c|c|}
\hline FS\# & Square & $\mathbf{X U}$ & Object \# & Description & Date & \# of Bags \\
\hline 417 & $\mathrm{~A}$ & 33 & - & $2.3 \mathrm{~mm}$ sieve residue & $16 / 05 / 2013$ & 1 \\
\hline 418 & $\mathrm{~A}$ & 33 & - & sediment sample & $16 / 05 / 2013$ & 1 \\
\hline 419 & $\mathrm{~A}$ & 33 & 1 & charcoal & $16 / 05 / 2013$ & 1 \\
\hline 420 & $\mathrm{~A}$ & 33 & 2 & charcoal & $16 / 05 / 2013$ & 1 \\
\hline 421 & $\mathrm{~A}$ & 33 & 3 & charcoal & $16 / 05 / 2013$ & 1 \\
\hline 422 & A & 33 & 4 & ground edge fragment & $16 / 05 / 2013$ & 1 \\
\hline 423 & $\mathrm{~A}$ & 33 & 5 & charcoal & $16 / 05 / 2013$ & 1 \\
\hline 424 & $\mathrm{~A}$ & 33 & 6 & charcoal & $16 / 05 / 2013$ & 1 \\
\hline 425 & $\mathrm{~A}$ & 33 & 7 & charcoal & $16 / 05 / 2013$ & 1 \\
\hline 426 & A & 33 & 8 & charcoal & $16 / 05 / 2013$ & 1 \\
\hline 427 & A & 33 & 9 & charcoal & $16 / 05 / 2013$ & 1 \\
\hline 428 & $\mathrm{~A}$ & 34 & - & $2.3 \mathrm{~mm}$ sieve residue & $16 / 05 / 2013$ & 1 \\
\hline 429 & $\mathrm{~A}$ & 34 & - & sediment sample & $16 / 05 / 2013$ & 1 \\
\hline 430 & $\mathrm{~A}$ & 34 & 1 & charcoal & $17 / 05 / 2013$ & 1 \\
\hline 431 & $\mathrm{~A}$ & 34 & 2 & charcoal & $17 / 05 / 2013$ & 1 \\
\hline 432 & $\mathrm{~A}$ & 34 & 3 & charcoal & $17 / 05 / 2013$ & 1 \\
\hline 433 & A & 34 & 4 & charcoal & $17 / 05 / 2013$ & 1 \\
\hline 434 & $\mathrm{~A}$ & 34 & 5 & charcoal & $17 / 05 / 2013$ & 1 \\
\hline 435 & $\mathrm{~A}$ & 34 & 6 & charcoal & $17 / 05 / 2013$ & 1 \\
\hline 436 & $\mathrm{~A}$ & 34 & 7 & charcoal & $17 / 05 / 2013$ & 1 \\
\hline 437 & $\mathrm{~A}$ & 34 & 8 & charcoal & $17 / 05 / 2013$ & 1 \\
\hline 438 & $\mathrm{~A}$ & 34 & 9 & charcoal & $17 / 05 / 2013$ & 1 \\
\hline 439 & $\mathrm{~A}$ & 34 & 10 & charcoal & $17 / 05 / 2013$ & 1 \\
\hline 440 & $\mathrm{~A}$ & 35 & - & $2.3 \mathrm{~mm}$ sieve residue & $17 / 05 / 2013$ & 1 \\
\hline 441 & A & 35 & - & sediment sample & $17 / 05 / 2013$ & 1 \\
\hline 442 & A & 35 & 1 & charcoal & $17 / 05 / 2013$ & 1 \\
\hline 443 & $\mathrm{~A}$ & 35 & 2 & charcoal & $17 / 05 / 2013$ & 1 \\
\hline 444 & $\mathrm{~A}$ & 35 & 3 & charcoal & $17 / 05 / 2013$ & 1 \\
\hline 445 & $\mathrm{~A}$ & 35 & 4 & charcoal & $17 / 05 / 2013$ & 1 \\
\hline 446 & $\mathrm{~A}$ & 35 & 5 & charcoal & $17 / 05 / 2013$ & 1 \\
\hline 447 & $\mathrm{~A}$ & 35 & 6 & charcoal & $17 / 05 / 2013$ & 1 \\
\hline 448 & $\mathrm{~A}$ & 35 & 7 & charcoal & $17 / 05 / 2013$ & 1 \\
\hline 449 & A & 36 & - & $2.3 \mathrm{~mm}$ sieve residue & $17 / 05 / 2013$ & 1 \\
\hline 450 & $\mathrm{~A}$ & 36 & - & sediment sample & $17 / 05 / 2013$ & 1 \\
\hline 451 & $\mathrm{~A}$ & 36 & 1 & charcoal & $17 / 05 / 2013$ & 1 \\
\hline 452 & $\mathrm{~A}$ & 36 & 2 & charcoal & $17 / 05 / 2013$ & 1 \\
\hline 453 & $\mathrm{~A}$ & 36 & 3 & charcoal & $17 / 05 / 2013$ & 1 \\
\hline 454 & $\mathrm{~A}$ & 37 & - & $2.3 \mathrm{~mm}$ sieve residue & $18 / 05 / 2013$ & 1 \\
\hline 455 & $\mathrm{~A}$ & 37 & - & sediment sample & $18 / 05 / 2013$ & 1 \\
\hline 456 & A & 38 & - & $2.3 \mathrm{~mm}$ sieve residue & $18 / 05 / 2013$ & 1 \\
\hline 457 & $\mathrm{~A}$ & 38 & - & sediment sample & $18 / 05 / 2013$ & 1 \\
\hline 458 & $\mathrm{~A}$ & 38 & 1 & charcoal & $18 / 05 / 2013$ & 1 \\
\hline 459 & $\mathrm{~A}$ & 38 & 2 & charcoal & $18 / 05 / 2013$ & 1 \\
\hline 460 & A & 39 & - & $2.3 \mathrm{~mm}$ sieve residue & $18 / 05 / 2013$ & 1 \\
\hline 461 & $\mathrm{~A}$ & 39 & - & sediment sample & $18 / 05 / 2013$ & 1 \\
\hline 462 & A & 39 & 1 & charcoal & $18 / 05 / 2013$ & 1 \\
\hline 463 & A & 39 & 2 & quartz artefact & $18 / 05 / 2013$ & 1 \\
\hline 464 & $\mathrm{~A}$ & 39 & 3 & quartz artefact & $18 / 05 / 2013$ & 1 \\
\hline 465 & $\mathrm{~A}$ & 40 & - & $2.3 \mathrm{~mm}$ sieve residue & $18 / 05 / 2013$ & 1 \\
\hline 466 & $\mathrm{~A}$ & 40 & - & sediment sample & $18 / 05 / 2013$ & 1 \\
\hline 467 & $\mathrm{~A}$ & 40 & 1 & quartz artefact & $18 / 05 / 2013$ & 1 \\
\hline 468 & - & - & - & Anadara antiquata $\left({ }^{14} \mathrm{C}\right.$ sample $)$ & $20 / 05 / 2013$ & 1 \\
\hline
\end{tabular}


Appendix I. Field specimen log, Site 3 Mangrove Beach Headland Midden, Square A (cont.).

\begin{tabular}{|c|c|c|c|c|c|c|}
\hline FS\# & Square & $\mathbf{X U}$ & Object \# & Description & Date & \# of Bags \\
\hline 469 & - & - & - & Anadara antiquata ( ${ }^{14} \mathrm{C}$ sample) & $20 / 05 / 2013$ & 1 \\
\hline 470 & - & - & - & Anadara antiquata $\left({ }^{14} \mathrm{C}\right.$ sample) & $20 / 05 / 2013$ & 1 \\
\hline 471 & - & - & - & Anadara antiquata $\left({ }^{14} \mathrm{C}\right.$ sample) & $20 / 05 / 2013$ & 1 \\
\hline 472 & - & - & - & Anadara antiquata $\left({ }^{14} \mathrm{C}\right.$ sample $)$ & $20 / 05 / 2013$ & 1 \\
\hline 473 & - & - & - & Anadara antiquata $\left({ }^{14} \mathrm{C}\right.$ sample $)$ & $20 / 05 / 2013$ & 1 \\
\hline 474 & A & 41 & - & $2.3 \mathrm{~mm}$ sieve residue & $20 / 05 / 2013$ & 1 \\
\hline 475 & A & 41 & - & sediment sample & $20 / 05 / 2013$ & 1 \\
\hline 476 & A & 41 & 1 & charcoal & $20 / 05 / 2013$ & 1 \\
\hline 477 & A & 41 & 2 & charcoal & $20 / 05 / 2013$ & 1 \\
\hline 478 & A & 42 & - & $2.3 \mathrm{~mm}$ sieve residue & $20 / 05 / 2013$ & 1 \\
\hline 479 & A & 42 & - & sediment sample & $20 / 05 / 2013$ & 1 \\
\hline 480 & A & 42 & 1 & charcoal & $20 / 05 / 2013$ & 1 \\
\hline 481 & A & 42 & 2 & charcoal & $20 / 05 / 2013$ & 1 \\
\hline 482 & A & 42 & 3 & charcoal & $20 / 05 / 2013$ & 1 \\
\hline 483 & A & 42 & 4 & quartz artefact & $20 / 05 / 2013$ & 1 \\
\hline 484 & A & 42 & 5 & charcoal & $20 / 05 / 2013$ & 1 \\
\hline 485 & A & 43 & - & $2.3 \mathrm{~mm}$ sieve residue & $20 / 05 / 2013$ & 1 \\
\hline 486 & $\mathrm{~A}$ & 43 & - & sediment sample & $20 / 05 / 2013$ & 1 \\
\hline 487 & A & 43 & 1 & charcoal & $20 / 05 / 2013$ & 1 \\
\hline 488 & A & 43 & 2 & charcoal & $20 / 05 / 2013$ & 1 \\
\hline 489 & A & 43 & 3 & charcoal & $20 / 05 / 2013$ & 1 \\
\hline 490 & A & 44 & - & $2.3 \mathrm{~mm}$ sieve residue & $21 / 05 / 2013$ & 1 \\
\hline 491 & $\mathrm{~A}$ & 44 & - & sediment sample & $21 / 05 / 2013$ & 1 \\
\hline 492 & A & 44 & 1 & charcoal & $21 / 05 / 2013$ & 1 \\
\hline 493 & A & 45 & - & $2.3 \mathrm{~mm}$ sieve residue & $21 / 05 / 2013$ & 1 \\
\hline 494 & A & 45 & - & sediment sample & $21 / 05 / 2013$ & 1 \\
\hline 495 & A & 46 & - & $2.3 \mathrm{~mm}$ sieve residue & $21 / 05 / 2013$ & 1 \\
\hline 496 & A & 46 & - & sediment sample & $21 / 05 / 2013$ & 1 \\
\hline 497 & A & 47 & - & $2.3 \mathrm{~mm}$ sieve residue & $21 / 05 / 2013$ & 1 \\
\hline 498 & A & 47 & - & sediment sample & $21 / 05 / 2013$ & 1 \\
\hline 499 & A & 48 & - & $2.3 \mathrm{~mm}$ sieve residue & $21 / 05 / 2013$ & 1 \\
\hline 500 & A & 48 & - & sediment sample & $21 / 05 / 2013$ & 1 \\
\hline 501 & A & 41 & 3 & charcoal & $20 / 05 / 2013$ & 1 \\
\hline 502 & A & 49 & - & $2.3 \mathrm{~mm}$ sieve residue & $22 / 05 / 2013$ & 1 \\
\hline 503 & A & 49 & - & sediment sample & $22 / 05 / 2013$ & 1 \\
\hline 504 & A & 50 & - & $2.3 \mathrm{~mm}$ sieve residue & $22 / 05 / 2013$ & 1 \\
\hline 505 & $\mathrm{~A}$ & 50 & - & sediment sample & $22 / 05 / 2013$ & 1 \\
\hline 506 & $\mathrm{~A}$ & 51 & - & $2.3 \mathrm{~mm}$ sieve residue & $22 / 05 / 2013$ & 1 \\
\hline 507 & $\mathrm{~A}$ & 51 & - & sediment sample & $22 / 05 / 2013$ & 1 \\
\hline 508 & A & 52 & - & $2.3 \mathrm{~mm}$ sieve residue & $22 / 05 / 2013$ & 1 \\
\hline 509 & A & 52 & - & sediment sample & $22 / 05 / 2013$ & 1 \\
\hline 510 & A & 53 & - & $2.3 \mathrm{~mm}$ sieve residue & $22 / 05 / 2013$ & 1 \\
\hline 511 & $\mathrm{~A}$ & 53 & - & sediment sample & $22 / 05 / 2013$ & 1 \\
\hline 512 & $\mathrm{~A}$ & 54 & - & $2.3 \mathrm{~mm}$ sieve residue & $23 / 05 / 2013$ & 1 \\
\hline 513 & A & 54 & - & sediment sample & $23 / 05 / 2013$ & 1 \\
\hline 514 & $\mathrm{~A}$ & 55 & - & $2.3 \mathrm{~mm}$ sieve residue & $23 / 05 / 2013$ & 1 \\
\hline 515 & A & 55 & - & sediment sample & $23 / 05 / 2013$ & 1 \\
\hline 516 & $\mathrm{~A}$ & 56 & - & $2.3 \mathrm{~mm}$ sieve residue & $23 / 05 / 2013$ & 1 \\
\hline 517 & A & 56 & - & sediment sample & $23 / 05 / 2013$ & 1 \\
\hline 518 & $\mathrm{~A}$ & 57 & - & $2.3 \mathrm{~mm}$ sieve residue & $23 / 05 / 2013$ & 1 \\
\hline 519 & $\mathrm{~A}$ & 57 & - & sediment sample & $23 / 05 / 2013$ & 1 \\
\hline 520 & A & 58 & - & $2.3 \mathrm{~mm}$ sieve residue & $23 / 05 / 2013$ & 1 \\
\hline
\end{tabular}


Appendix I. Field specimen log, Site 3 Mangrove Beach Headland Midden, Square A (cont.).

\begin{tabular}{|c|c|c|c|l|c|c|}
\hline FS\# & Square & XU & Object \# & Description & Date & \# of Bags \\
\hline 521 & A & 58 & - & sediment sample & $23 / 05 / 2013$ & 1 \\
\hline 522 & A & 59 & - & 2.3 mm sieve residue & $23 / 05 / 2013$ & 1 \\
\hline 523 & A & 59 & - & sediment sample & $23 / 05 / 2013$ & 1 \\
\hline
\end{tabular}

